Rita de Cassia de Almeida

\title{
A QUESTÃO HÍDRICA NA GESTÃO URBANA PARTICIPATIVA: $O$ CASO DO ORÇAMENTO PARTICIPATIVO DO MUNICÍPIO DE
} SÃO CARLOS, SP

Tese apresentada à Escola de Engenharia de São Carlos da Universidade de São Paulo, como parte dos requisitos para a obtenção do Título de Doutor em Ciências da Engenharia Ambiental.

Orientadora: Prof. Dra. Norma Felicidade Lopes da Silva Valencio

São Carlos

2005 
À minha família 


\section{AGRADECIMENTOS}

À Prof ${ }^{a}$ Dr $^{\mathrm{a}}$ Norma Felicidade Lopes da Silva Valencio, pela orientação sempre presente e pelo exemplo de cientista dedicada e fiel aos seus ideais.

A banca de defesa composta pelo Prof. Associado Evaldo Luiz Gaeta Espíndola, pelo Prof. Dr. Bernardo Arantes do Nascimento Teixeira, pela Dra. Regina Célia Di Ciommo e pelo Prof. Associado Valdir Schalch.

À Coordenação e aos funcionários do PPG/SEA pelo apoio e colaboração.

A André Salvador pela elaboração dos mapas.

A minha prima Maria de Lourdes pela revisão do texto.

A minha amiga Edna Tenório pela correção do Abstract.

A todas as pessoas que direta ou indiretamente colaboraram para a realização desse trabalho. 


\section{RESUMO}

ALMEIDA, R. de C. de. (2005). A questão hídrica na gestão urbana participativa: o caso do Orçamento Participativo do Município de São Carlos, SP - Escola de Engenharia de São Carlos, Universidade de São Paulo, São Carlos, 2005.

O quadro ambiental mundial tem sido negativamente alterado e de forma cada vez mais intensa, particularmente quando relacionado aos recursos hídricos. Para que esse quadro sofra alterações positivas, entendemos ser imprescindível a participação da sociedade civil na implantação de políticas públicas e na fiscalização das ações promovidas pelos governos locais, promovendo o uso equilibrado desse recurso. No atual contexto sociopolítico brasileiro, estão sendo criados novos espaços públicos de discussão e deliberação, que proporcionam a participação da sociedade civil na gestão pública. Entre esses novos espaços está o Orçamento Participativo (OP), que pode se tornar ferramenta de práticas políticas includentes e orientadas para a formulação e implementação de ações públicas, visando ao planejamento de cidades com qualidade socioambiental. Com a institucionalização do OP pelo governo municipal de São Carlos/SP, a sociedade civil local tem a oportunidade de participar das discussões e deliberações no que diz respeito às intervenções ambientais em sua cidade, em várias de suas dimensões. Todavia, o desenvolvimento do trabalho mostrou que não existem garantias de que o heterogêneo tecido social são-carlense responda favoravelmente e apropriadamente a essa oportunidade. Verificou-se que a particularidade do desenho institucional do OP/SC tem causado dificuldade na participação de uma parcela da sociedade civil, assim como, a ausência de convívio com uma gestão municipal mais participativa, justificada pela mesma elite que se perpetuou no poder por muito tempo. Também constatamos, por parte dos participantes, a dificuldade na deliberação nas intervenções urbanas de maior porte, principalmente, no que diz respeito aos seus recursos hídricos. No que concerne às propostas, é necessário observar a necessidade de se modificar alguns pontos do desenho institucional do OP, a fim de propiciar a todos os segmentos da sociedade civil são-carlense a oportunidade de participar e/ou deliberar de modo eficaz e que o movimento ambiental local possa ter um espaço de discussão sobre as questões ambientais locais, particularmente sobre os seus recursos hídricos.

Palavras-chave: meio ambiente, recursos hídricos, orçamento participativo, sociedade civil, participação. 


\section{ABSTRACT}

ALMEIDA, R. de C. de. (2005). Water resources matter in participatory urban management: the case of the Participatory Budgeting of São Carlos, SP, Brazil - Escola de Engenharia de São Carlos, Universidade de São Paulo, São Carlos, 2005.

The world environmental scene has been negatively altered and in a intense way, particularly with relation to the water resources. To change this scene positively, the civil society participation in the implantation of public politics and the fiscalization of the actions promoted by the local governments is indispensable to promote the balanced use of that resource. At the actual Brazilian sociopolitical context, new public spaces for debate and deliberation are being created, providing the participation of the civil society in the public administration. Among those is the Participatory Budgeting (PB), that can become a tool of inclusive political practices, orientated to the formulation and implementation of public actions aiming to plan cities with socioenvironmental quality. With the PB implantation by the São Carlos/SP municipal government, the local civil society has the opportunity to participate of the discussions and deliberations with respect to the environmental interventions in its city, in several senses. However, the development of the work showed that there are no warranties that the local heterogeneous social net responds favorable and adequately to this opportunity. It was verified that the particularity of the institutional drawing of the $\mathrm{PB} / \mathrm{SC}$ has been causing difficulties to the participation of a portion of the civil society and the absence of cohabitation with a more participatory municipal administration, explained by the same elite that was perpetuated in the power, for a long time. It was also verified, for the participants part, the difficulty to deliberate about the larger urban interventions, mainly with respect to their water resources. Regarding to the proposals, it is necessary to observe the need to modify some points of the institutional drawing of $\mathrm{PB}$, in order to propitiate for all the local civil society segments the opportunity to participate and to deliberate efficiently and the local environmental movement can have a space to discuss the local environmental subjects, their water resources in particular.

Key words: environment, water resources, participatory budgeting, civil society, participation. 


\section{Lista de Figuras}

Figura 1 Mapa do Município de São Carlos $\quad 68$

Figura 2 Mapa de Expansão Urbana 71

Figura 3 Divisão Regional da Área Urbana $\quad 80$

Figura 4 Foto da Reunião de Conselheiros e Delegados / Fase Deliberativa 84

Figura 5 Foto da Reunião da Comunidade de uma das regiões do OP / Fase 84 Informativa

Figura 6 Foto da Reunião da Comunidade de uma das regiões do OP / Fase 85 Informativa

Figura 7 Foto da Reunião da Comunidade de uma das regiões do OP / Fase Informativa

Figura 8 Foto da Reunião de Conselheiros e Delegados / Fase Deliberativa

Figura 9 Foto da Reunião de Conselheiros e Delegados / Fase Deliberativa

Figura 10 Foto da Reunião de Conselheiros e Delegados / Fase Deliberativa

Figura 11 Foto da Reunião de Conselheiros e Delegados / Fase Deliberativa

Figura 12 Mapa Demandas de Implantação/Manutenção Arborização Urbana / 2002

Figura 13 Mapa Demandas de Implantação/Manutenção Arborização Urbana / 2003

Figura 14 Mapa Demandas de Implantação/Manutenção Arborização Urbana / 2004

Figura 15 Mapa Demandas de Área de Lazer / 2001

Figura 16 Mapa Demandas de Área de Lazer / 2002

Figura 17 Mapa Demandas de Área de Lazer / 2003

Figura 18 Mapa Demandas de Área de Lazer / 2004

Figura 19 Mapa Demandas de Implantação/Manutenção Áreas Verdes / 2002

Figura 20 Mapa Demandas de Implantação/Manutenção Áreas Verdes / 2003 
Figura 22 Mapa Demandas por Canalização de Rio / 2001

Figura 23 Mapa Demandas por Coleta Seletiva / 2002

Figura 24 Mapa Demandas por Combate a Enchentes / 2001

Figura 25 Mapa Demandas por Combate a Enchentes /2002

Figura 26 Mapa Demandas por Combate à Erosão / 2001

Figura 27 Mapa Demandas por Combate à Erosão / 2002

Figura 28 Mapa Demandas por Combate à Erosão / 2003

134

Figura 29 Mapa Demandas por Combate à Erosão / 2004

Figura 30 Mapa Demandas de Implantação/Manutenção Galerias Pluviais / 2001

135

Figura 31 Mapa Demandas de Implantação/Manutenção Galerias Pluviais / 2002

Figura 32 Mapa Demandas de Implantação/Manutenção Galerias Pluviais / 2003

135

Figura 33 Mapa Demandas de Implantação/Manutenção Galerias Pluviais / 2004

Figura 34 Mapa Demandas por Limpeza de Rio / 2001 136

Figura 35 Mapa Demandas por Limpeza de Rio / 2002

Figura 36 Mapa Demandas por Lixeiras / 2002

Figura 37 Mapa Demandas por Combate a Poluição Industrial / 2002

Figura 38 Mapa Demandas por Combate a Poluição Sonora / 2002

Figura 39 Mapa Demandas de Implantação/Manutenção por Praças / 2001

Figura 40 Mapa Demandas de Implantação/Manutenção por Praças / 2002

Figura 41 Mapa Demandas de Implantação/Manutenção por Praças / 2003

Figura 42 Mapa Demandas de Implantação/Manutenção por Praças /2004

Figura 43 Mapa Demandas de Projetos de Preservação Ambiental / 2002 
Figura 44 Mapa Demandas de Projetos de Preservação Ambiental / 2003

Figura 45 Mapa Demandas Combate a Queimadas / 2002

Figura 46 Mapa Demandas por Recuperação de Curso D’ Água / 2004

Figura 47 Mapa Demandas de Implantação/Manutenção Redes de Esgoto / 2001 140

Figura 48 Mapa Demandas de Implantação/Manutenção Redes de Esgoto / 2002 140

Figura 49 Mapa Demandas de Implantação/Manutenção Redes de Esgoto / 2004

Figura 50 Mapa Demandas por Tratamento de Esgoto / 2001

Figura 51 Mapa Demandas por Tratamento de Esgoto / 2002

Figura 52 Mapa Demandas de Implantação/Manutenção de Estação Coletora / Usina de Reciclagem / 2004

Figura 53 Mapa da Bacia Hidrográfica do Rio do Monjolinho

Figura 54 Foto da Região 08 - Rio do Monjolinho 145

Figura 55 Foto da Região 08 - Rio do Monjolinho 145

Figura 56 Foto da Região 04 - Córrego do Sorregoti 147

Figura 57 Foto da Região 04 - Córrego do Lazarini 147

Figura 58 Foto da Região 04 - Córrego do Gregório 148

Figura 59 Foto da Região 04 - Córrego do Gregório 148

Figura 60 Foto da Região 04 - Córrego do Tijuco Preto 150

Figura 61 Foto da Região 11 - Córrego do Tijuco Preto 150

Figura 62 Foto da Região 11 - Córrego Santa Maria do Leme 151

Figura 63 Foto da Região 11 - Córrego Santa Maria do Leme 151

Figura 64 Foto da Região 08 - Córrego do Mineirinho 152

Figura 65 Foto da Região 08 - Córrego do Mineirinho 


\section{Lista de Quadros}

Quadro 1 Caracterização do Município de São Carlos

Quadro 2 Divisão Regional da Área Urbana

Quadro 3 Critérios, pesos e notas para distribuição dos investimentos

Quadro 4 Tabela de Proporcionalidade para a eleição de conselheiros do COP

Quadro 5 Tabela de proporcionalidade de delegados das regiões e plenárias temáticas

Quadro 6 Detalhamento do Regimento Interno do OP / São Carlos

Quadro 7 Tabulação dos dados dos questionários

Quadro 8 Detalhamento das Regiões

Quadro 9 Proporção de demandas - obras/obras verdes / 2001

Quadro 10 Proporção de demandas - obras/obras verdes / 2002

Quadro 11 Proporção de demandas - obras/obras verdes / 2003

Quadro 12 Proporção de demandas - obras/obras verdes / 2004

Quadro 13 Proporção de demandas - obras/obras verdes / 2001 a 2004

Quadro 14 Diagnóstico de Demandas Verdes por Região / de 2001 a 2004 


\section{Lista de Gráficos}

Gráfico 1 Total de Demandas Verdes / 2001

Gráfico 2 Confronto por Região entre Demandas Verdes e as Demais/2001

115

Gráfico 3 Total de Demandas Verdes / 2002

118

Gráfico 4 Confronto por Região entre Demandas Verdes e as Demais/2002

Gráfico 5 Total de Demandas Verdes / 2003

Gráfico 6 Confronto por Região entre Demandas Verdes e as Demais/2003

Gráfico 7 Total de Demandas Verdes / 2004

Gráfico 8 Confronto por Região entre Demandas Verdes e as Demais/2004

Gráfico 9 Total de Demandas Verdes / 2001 a 2004

Gráfico 10 Confronto por Região entre Demandas Verdes e as Demais / 2001 a 2004 


\section{Sumário}

Resumo iv

Abstract v v

Lista de Figuras vi vi vas

Lista de Quadros $\quad$ ix

Lista de Gráficos $\quad x$

Introdução 12

Capítulo 1 - Participação, cidadania e novos movimentos sociais 15

1.1. Participação e cidadania $\quad 15$

1.2. Os novos movimentos sociais 28

Capítulo 2 - Meio ambiente e participação 37

2.1. O movimento ambiental brasileiro 37

2.1.1. Introdução 37

2.2. Breve histórico da evolução do movimento ambiental brasileiro $\quad 40$

2.3. Considerações sobre a questão hídrica 44

2.4. Considerações sobre a gestão ambiental no Brasil 48

2.5. Considerações sobre a questão urbana e a participação política da 51 sociedade civil brasileira

Capítulo 3 - O Orçamento Participativo e o Município de São

Carlos

3.1. Gênese sociopolítica do Orçamento Participativo 58

3.2. O município de São Carlos: localização e ocupação 66

3.3. O movimento ambiental no município de São Carlos 74

3.4. Desenho institucional do Orçamento Participativo de São Carlos 78

3.4.1. O processo participativo 78

3.4.2. Sobre o funcionamento das Assembléias 82

3.5. Metodologia 95

Capítulo 4 - Resultados e Discussão 96

4.1. Tabulação dos dados dos questionários 97

4.2. Tabulação dos dados das demandas $\quad 115$

4.3. As intervenções dos participantes do OP/SC nas micro-bacias $\quad 142$

hidrográficas urbanas

Capítulo 5 - O estudo de caso a luz do arcabouço teórico 183

Considerações Finais 189

Referências Bibliográficas 192 


\section{Introdução}

A população mundial vem sofrendo, nas últimas décadas, uma série de problemas ambientais, dentre os quais, alcançou maior amplitude aquele relacionado à escassez de água, fruto de uma demanda cada vez maior, tanto em razão do crescimento acelerado da população quanto do aumento de sua utilização, reflexo do padrão de desenvolvimento e conforto impostos pela moderna vida urbana. A qualidade e quantidade das águas doces vêm sendo alteradas rapidamente e esse processo logo pode tornar-se irreversível, particularmente nos territórios mais povoados dos países emergentes, como no caso do Brasil.

Essa questão não é mais privilégio somente das metrópoles, reflete-se também nas cidades médias interioranas, que, além disso, sofrem também e, cada vez mais, com a desigualdade social e carência de equipamentos básicos de infra-estrutura urbana. Além do que, é cada vez maior o número de municípios que vivem a falência de suas políticas administrativas. Logo, a degradação ambiental, principalmente àquela relacionada às águas doces, alcança territórios antes não atingidos, levando a um quadro de desigualdade socioambiental.

Os municípios brasileiros confrontam-se com situações urgentes, que pedem intervenções rápidas em áreas que vão além das tradicionais políticas públicas urbanas, intervenções para as quais não há a devida mobilização e participação da sociedade civil na definição de políticas públicas pertinentes. Portanto, tornaram-se tarefas que não podem ser adiadas, - o uso equilibrado dos recursos hídricos aliado à elaboração e efetivação de políticas públicas específicas com a participação da sociedade civil, tanto em sua gestão quanto na fiscalização das ações promovidas pelo poder público.

Nesse momento, no Brasil, a discussão teórica dá conta da emergência de uma nova sociedade civil, onde esses novos sujeitos poderão assumir a parcela de participação que lhes cabe nesse processo. A institucionalização de espaços públicos deliberativos figura-se como um canal por meio do qual esses sujeitos tomarão seu lugar na gestão e fiscalização de políticas públicas. 
Dentre esses novos espaços que estão indo de encontro à tradicionalidade política brasileira, enquadra-se à proposta do Orçamento Participativo (OP). O arcabouço teórico está levantando o debate de que a institucionalização desse espaço traz a possibilidade do poder local vir a atender os interesses da sociedade civil em sua totalidade, isto é, que o OP seria um novo modelo de gestão, distributivamente mais justo e participativo.

Contudo, importa saber se a emergência desses novos sujeitos sociais pode ser espraiada as muitas localidades que têm a institucionalização desse espaço e/ou pretendem tê-lo. Ou ainda, se o OP pode vir a ser uma ferramenta eficaz na resolução de uma das questões socioambientais urbanas mais prementes, ou seja, a recuperação e/ou conservação dos recursos hídricos.

Uma das experiências de OP em curso é a do atual governo do município de São Carlos, estado de São Paulo. Nesse estudo de caso, temos por objetivo analisar criticamente se a sociedade civil são-carlense pode vir a ser mais participante na gestão municipal, pela análise de sua percepção sobre as questões ambientais urbanas e pelas discussões e deliberações sobre questões socioambientais importantes, especialmente, no que se refere à gestão de seus recursos hídricos.

A fim de atingir esse objetivo adotaremos os métodos quantitativo e qualitativo, justificado pelo próprio caráter das possíveis informações a serem obtidas. A abordagem qualitativa será aplicada para entender as conseqüências iniciais da institucionalização de um espaço público de discussão e deliberação inédito como é o OP. Para tal, realizamos uma pesquisa bibliográfica que leva a uma revisão bibliográfica do debate sobre participação da sociedade civil, sobre a emergência de novos sujeitos e organizações sociais, sobre os novos movimentos sociais e sobre a evolução do movimento ambiental brasileiro. Assim como, análise dos relatos de participantes do movimento ambiental local, da aplicação da técnica de observação direta e de questionários estruturados e semiestruturados. O método quantitativo será aplicado para descobrir e classificar a relação nos estudos dos questionários e das demandas de obras e serviços solicitadas nas Assembléias Populares Regionais e Deliberativas.

No Capítulo 1, trataremos de elucidar os debates teóricos acerca das questões referentes à emergência dessa nova sociedade civil. Para tal, recorreremos às bibliografias 
recentes sobre participação, cidadania e novos movimentos sociais, buscando referenciais teóricos para a discussão com o estudo de caso.

No Capítulo 2, deter-nos-emos mais atentamente em um novo movimento social específico - o movimento ambiental, discorrendo sobre as mais urgentes questões ambientais brasileiras, como a questão dos recursos hídricos, da gestão ambiental e da urbanização e participação da sociedade civil. Tal procedimento fornecerá subsídios para a discussão dessas questões no âmbito do município de São Carlos.

No Capítulo 3, partiremos primeiramente para a discussão teórica da gênese sociopolítica do OP. Em seguida, iniciamos o estudo de caso com um histórico da ocupação do município de São Carlos e sua atual situação socioambiental. Em seguida, detalhamos sobre o desenho institucional do OP de São Carlos (OP/SC), a fim de discutirmos se esse oferece à sociedade civil real oportunidade de participação. Na sequiência elucidamos a metodologia utilizada para tal investigação. E, por fim, partiremos para a tabulação e análise dos dados colhidos no período de 2001 a 2004.

No Capítulo 4, discutiremos os resultados das análises feitas no Capítulo 3 colocados à luz do arcabouço teórico atual. 


\section{CAPÍTULO 1 - Participação, Cidadania e Novos Movimentos Sociais}

\subsection{Participação e cidadania}

No Brasil, o debate sobre participação teve início na década de 1980, recuperando e valorizando alguns clássicos, como A. Gramsci, e trazendo novas questões em função de um novo contexto, a redemocratização do país. Do ponto de vista clássico, valorizou-se muito o recorte gramisciniano dessa questão da sociedade civil que se fortalece de uma questão dialética a um Estado autoritário. Na vertente gramsciniana, esse processo se dá em quatro etapas que atuam e combinam entre si, de acordo com as diferentes circunstâncias histórico-sociais, assim como, de acordo com os diferentes graus de consciência política coletiva, refletindo maior ou menor maturidade, homogeneidade e organicidade dos grupos sociais.

A primeira dessas modalidades é a participação assistencialista, de natureza filantrópica ou solidária. Tem como característica dominante à participação anterior à afirmação dos direitos de cidadania, podendo também predominar nos estágios de menor maturidade e de menor organização dos grupos sociais ou ainda de menor consciência política coletiva.

A participação corporativa é a segunda dessas modalidades e é característica dominante a participação fechada em si, onde ganham apenas os pertencentes ao grupo e esteve na origem do sindicalismo moderno. 
A primeira e a segunda modalidades de participação podem ser integradas em uma dimensão pré-política da organização moderna, em que os grupos vêem a necessidade de união, a fim de se defender ou negociar em melhores condições os termos de sua incorporação à sociedade moderna. Num primeiro estágio, reivindicam ser reconhecidos como distintos, diferentes, contrapostos ao todo e aos demais grupos, portanto, dedicados a construir uma identidade e uma agenda próprias.

A terceira dessas modalidades de participação é a eleitoral, inserida no campo político propriamente dito. Nessa modalidade de participação, o cidadão está mais maduro, afirmando-se não somente com relação aos seus direitos individuais, como também com relação aos direitos dos outros - os direitos políticos. Entretanto, a participação eleitoral tem seus limites e não leva necessariamente a uma reorganização sustentada do Estado ou do poder político, condicionada por atos e escolhas individuais, particulares.

A quarta dessas modalidades de participação é a política, que complementa e supera tanto a participação eleitoral quanto à participação corporativa. A participação política tem em vista a comunidade como um todo e a organização da vida social em seu conjunto, ou seja, o Estado. Uma prática ético-política contempla tanto a questão do poder e da dominação, quanto a questão do consenso e da hegemonia. Portanto, é essa participação que dá dinamismo, proteção e fortalece o exercício da cidadania.

Consideramos que a participação assistencialista e corporativa é ainda muito presente em vários momentos da sociedade civil brasileira. A participação eleitoral é recente na história política do país, com vistas a alcançar progressivamente a maturidade necessária rumo ao fortalecimento do exercício da cidadania. Entretanto, a participação política ainda é muito incipiente e é justamente esse tipo de participação o berço para o surgimento de novos sujeitos sociais capazes de promover a transformação democrática do país.

No que se refere ao processo de emergência de novos sujeitos sociais no cenário teórico político brasileiro, identificamos a tendência de se pensar esse fenômeno, que pode estar em curso, como resultado, por um lado, do processo de modernização social e econômica; e por outro, da contribuição de novos fenômenos como a urbanização, a complexificação do ensino e a criação de macroestruturas empresariais e estatais.

Autores como E. Dagnino; L. Avritzer; M. A. Nogueira levantam o debate de que essa nova sociedade civil pode promover uma transformação democrática no país, mas, 
também alertam que a possibilidade da existência de sujeitos sociais modernos, promovendo o resgate de idéias de livre-associação e crítica política, não constitui, por si só, condição suficiente para o aparecimento e fortalecimento de uma sociedade civil moderna.

A grande dificuldade para o surgimento dessa sociedade civil moderna era a de se firmar opondo-se a e questionando um regime autoritário, defensor de um projeto político de criação de sujeitos sociais despolitizados (HOLANDA, 1993; SCHWARTZAMN, 1988; FAORO, 1958). Ainda hoje, observamos a persistência de práticas políticas dominantes no interior das elites brasileiras, que têm o discurso da modernidade democrática, mas sem conseqüências práticas. L. Avritzer defende que essa particularidade brasileira seria fruto da incapacidade de adaptação política às mudanças supostas pelo processo de modernização social, que tornou a democratização social dependente da inovação social e não uma relação direta entre ação e estrutura.

Entretanto, se o atual contexto sócio-político e cultural brasileiro favoreceu o aparecimento de uma parcela da sociedade civil onde residem novos sujeitos, novas organizações e práticas sociais, indagamos se esse quadro que ora se descortina, permitirá o surgimento de uma sociedade civil moderna, com sujeitos sociais efetivamente partícipes.

Para E. Dagnino; L. Avritzer e M. A. Nogueira quanto mais a democracia representativa no Brasil foi mostrando-se ineficiente, mais fortalecida ficava, em importantes segmentos da sociedade, a perspectiva de que a resolução das urgentes questões sociais, econômicas e ambientais não mais passaria pela representatividade. E é esse momento que torna propício o surgimento de novos sujeitos sociais.

A democracia participativa passa a ser uma referência impossível de ser ignorada, pois, com o processo de democratização cada vez mais fortalecido por meio da participação eleitoral, a sociedade civil passa a exigir mais participação e presença ativa nas tomadas de decisões (NOGUEIRA, 2004), ou seja, há o surgimento e fortalecimento da participação política.

Os espaços em que os cidadãos podem exercer algum tipo de poder de deliberação, alternando o peso relativo da representação política, estão sendo ampliados. Entretanto, em nosso ponto de vista, esse processo não deve tanto ser estendido a todo o país quanto considerado abrangente e eficaz a todos os segmentos da sociedade civil e nem, tampouco, 
transformador da cultura política do autoritarismo, clientelismo e despolitização enraizada na sociedade brasileira. Pesquisas e análise dos resultados alcançados em algumas experiências participativas (SANTOS, 2002; FEDOZZI, 2000; VIEIRA, 2000) estão sendo feitas e o quadro delineado pela participação política da sociedade civil brasileira em espaços públicos ainda indica que o processo de construção democrática não é linear, mas ao contrário, é contraditório e fragmentado.

Observamos a perspectiva de DAGNINO (2002) onde essa particularidade demonstra que esse processo se vincula a mais de um fator, eliminando qualquer possibilidade de se pensar somente a sociedade civil brasileira como "o" berçário do aprofundamento democrático. Esse processo açambarca o Estado, não somente considerado como conjunto de forças que ocupam o poder em seus três níveis (municipal, estadual e federal), mas, principalmente, a estrutura estatal, cujo desenho autoritário permanece largamente intocado e resistente aos impulsos participativos. Inclui, ainda, os partidos políticos, mediadores tradicionais entre a sociedade civil e o Estado. E é característica dos partidos políticos a inclinação sempre na direção do Estado, limitando sua busca de representatividade na sociedade civil aos momentos eleitorais e aos mecanismos vistos como mais eficazes nestes momentos, ou seja, o clientelismo, as relações de favor, o personalismo etc. Assim, a busca por parte de organizações da sociedade civil de relações mais diretas com o Estado, certamente se vincula também a essa multiplicidade de fatores.

Em suma, consideramos que a complexidade inerente ao surgimento dessa nova sociedade civil, de novas organizações e práticas sociais e dos recém criados espaços públicos no Brasil, inclui também os possíveis embates entre organizações dessa sociedade civil e partidos, ao lado dos conflitos entre a representatividade advinda das urnas e aquela que se articula nos espaços de participação.

Através da emergência de uma nova sociedade civil, com novos sujeitos e novas organizações sociais, emerge também a possibilidade de transformação cultural promovida pela prática social no interior delas. Esses temas mobilizam autores como B. S. Santos; E. Dagnino e L. Avritzer que levam ao debate o peso das matrizes culturais no processo de construção democrática.

As transições democráticas ao inserirem os movimentos sociais e o associativismo corporativo como novos sujeitos do cenário político, irão instaurar uma disputa pelo 
significado da democracia e pela constituição de uma nova gramática social. Essa situação levará o debate democrático a ter de lidar com três importantes questões: a da relação entre procedimento e participação social; a da relação entre representação e diversidade social e cultural e da maior ou menor adequação da solução burocrática e não participativa a nível local (SANTOS \& AVRITZER, 2002).

A forma como essas três questões serão apropriadas pelos sujeitos atuantes somente virá à tona através de estudos de caso, quando emergem, tanto os possíveis processos culturais de mudanças, as dificuldades de participação e de relação com a diversidade sociocultural e a possível interferência do aparato estatal nesses processos.

De acordo com DAGNINO (2002), existe uma significativa unanimidade nos relatos das experiências estudadas em relação ao reconhecimento de seu impacto positivo sobre o processo de construção de uma cultura mais democrática na sociedade brasileira. E esse reconhecimento se dá até mesmo nos casos onde a avaliação do impacto mais geral é predominantemente negativa. Essa participação da sociedade civil na busca de reconhecimento e solução de demandas de direitos tem alterado a face da sociedade brasileira, ao longo das duas últimas décadas do século XX. E o fato, inquestionável, de que essas demandas encontrem escasso abrigo nas políticas públicas do Estado não deve obscurecer o avanço que a busca e legitimações no âmbito societal significam.

Acordamos com E. Dagnino, que isso se daria por conta da convivência com as diferenças no interior desses espaços, possibilitando a promoção do difícil aprendizado do reconhecimento do outro, enquanto portador de direitos e da existência e legitimidade do conflito, enquanto dimensões constitutivas da democracia e da cidadania. Por outro lado, esse ineditismo pode estimular a consolidação da capacidade propositiva dos NMS e outros setores da sociedade civil que, recentemente, passaram a unir forças em prol de suas propostas, possibilitando a superação da cultura particularista ou corporativista que sempre dominou a sociedade civil brasileira. Esses espaços serviriam de canais de expressão e defesa de reivindicações de direitos dos excluídos da cidadania no Brasil. Essa possibilidade também contribuiria para o reconhecimento desses direitos por parte da sociedade como um todo, mesmo quando esse reconhecimento não se traduz imediatamente em medidas concretas. 
Entretanto, destacamos a possibilidade do Estado poder ainda estar perpetuando as noções elitistas e autoritárias, tanto sobre o exercício democrático quanto em seu processo decisório, pois, apesar da existência desses espaços públicos, o Estado, através de mecanismos institucionais, pode agir no interior desses, interferindo na interação entre os seus diversos sujeitos atuantes.

Na perspectiva de autores como E. Dagnino e L. Avritzer, que se debruçam na análise dessa nova sociedade civil e de novas práticas socais advindas desse recente quadro sóciopolítico, mesmo com as possíveis dificuldades encontradas, vislumbra-se nesse processo a grande novidade capaz de mudar a face política e cultural do Brasil.

DAGNINO (2002) levanta o debate de que se deve levar em conta o histórico dos movimentos sociais no Brasil, quando, nas décadas de 1970 e 1980, foram entusiasticamente recebidos, em algumas versões, até como os novos sujeitos de uma revolução. A partir do momento em que as expectativas não foram cumpridas, decretou-se a sua crise e refluxo, ou simplesmente a sua irrelevância para a consolidação democrática. Por isso, atribuir indiscriminadamente, aos espaços de participação da sociedade civil, o papel de agentes fundamentais para a transformação do Estado e da sociedade, para a eliminação da desigualdade e para a instauração da cidadania pode gerar expectativas que não serão cumpridas, ou efetivadas completamente. A utilização desses parâmetros de avaliação pode, fatalmente, levar-nos à constatação do fracasso desses espaços, o que pode não ser real.

Também observamos que a análise desses espaços públicos pode levar a avaliações importantes e eles não podem ser discutidos como resultantes do potencial democratizante de uma única e homogênea variável, ou seja, a participação da sociedade civil; mas sim, como resultado de relações complexas de forças heterogêneas, envolvendo uma diversidade de sujeitos e de grupos, disputando projetos políticos diferenciados e com interesses diversos.

Acrescentamos, ainda, que é imprescindível a avaliação do papel desempenhado pelo Estado, especialmente, no caso dos espaços públicos institucionalizados embora, algumas vezes, o seu papel seja exclusivamente de mediador nessa disputa entre sujeitos e grupos repletos de diferenças e diversidades socioculturais. 
Nessas perspectivas, entendemos que, ao invés de ser recebida como a nova panacéia universal, especialmente num país como o Brasil, onde as dificuldades de organização popular são grandes, essa participação poderá ser mais bem entendida, se examinada, não somente nas relações internas e na diversidade que a sociedade civil tende a esconder, mas, também considerando as relações que essa participação mantém com a multiplicidade de dimensões, organizações estatais ou não, e sujeitos que compõem o cenário onde ela se dá.

Conseqüentemente, a nosso ver, para tal avaliação, é imprescindível a particularização dos contextos concretos dessa participação, a explicitação desses cenários complexos e o entendimento tanto positivos quanto negativos do seu impacto sobre cada um deles. Assim, podem-se evitar as generalizações apressadas em relação à contribuição da participação da sociedade civil na construção democrática. E esse processo é, na maioria das vezes, sempre desigual no seu ritmo e no seu alcance.

Assim, com o encadeamento desse momento de transição sociopolítica e cultural, podemos estar assistindo a uma expansão da cidadania, com a consolidação das conquistas alcançadas nos séculos passados, assim como, com os novos direitos e garantias proclamadas e reivindicadas. No entanto, ainda longe de ter alcançado um padrão estável.

Tornou-se questão premente do final do século XX encontrar soluções, a fim de atenuar o conflito existente entre a riqueza e a cidadania. A sociedade moderna acentuou novos problemas sociais: a pobreza persistente, o desemprego continuado por longos períodos e a degradação do meio ambiente, e mesmo as novas questões da cidadania e os antigos instrumentos do estado social não parecem ser capazes de saná-los.

No que se refere à expansão do conceito de cidadania e da reivindicação de direitos de novo tipo, expressivos autores que discutem esse momento particular, suas intervenções e conseqüências como, E. Jelin; M. A. Nogueira; M. L. Manzini Covre; R. Putnam, trazem para o debate a questão da forma como o conceito de cidadania está sendo apropriado pelo imaginário, pelas representações e pelas práticas. Assim como, o consenso de que o exercício efetivo da cidadania ativa, leva a sociedade civil à conscientização de que é mister a institucionalização de controles sobre as ações dos governantes. A inexistência desse controle e a não extensão dos direitos socioambientais às camadas mais pobres e marginalizadas da população, mantêm a forte hierarquização social. Esse processo alimenta 
o paternalismo, a economia de subsistência e estratégias de sobrevivência que impedem o desenvolvimento de identidades de grupo.

A emergência dessa nova sociedade civil pode ser uma forma para a construção democrática e de transformação social, levando ao fortalecimento do vínculo entre as dimensões da cultura e da política. Consideramos que esse caminho está se abrindo a partir da emergência de novos sujeitos e da institucionalização de novas organizações sociais e, conseqüentemente, das novas práticas advindas destas.

A cidadania, como princípio de prática social, açambarca uma série de valores e expectativas. As concepções de cidadania variam desde a abordagem clássica ${ }^{1}$, passando por concepções mais recentes até à chamada cidadania ativa. Partimos do princípio de pensar a cidadania como a possibilidade de efetivamente alcançarmos os valores e expectativas que esse conceito carrega. De nosso ponto de vista o seu exercício é uma forma de transformação social e busca do pleno exercício do direito a ter direitos.

A cidadania ativa é um produto social que exige tempo de maturação para seu surgimento e fortalecimento. Assim, assentimos com a afirmação de NOGUEIRA (2004) que parte do pressuposto de que essa mudança é fruto da ação recíproca entre o Estado, o processo de crescimento econômico e certos elementos culturais de um país. O exercício dessa cidadania exige um equilíbrio entre os espaços público e privado.

No Brasil, no entanto, houve somente o desenvolvimento dos direitos políticos em relação aos direitos civis (igualdade perante a lei, liberdade, propriedade). Assim, deixou-se de construir um espaço público como parte integrante de um governo democrático, espaço este onde se conciliam interesses divergentes. Por fim, esses fatores (sociais, políticos e

${ }^{1}$ O conceito clássico de cidadania elaborado por MARSHALL (1967) insere-se no contexto histórico do liberalismo e na afirmação do indivíduo e da sociedade civil sobre o Estado. Revela a preocupação inserida na noção de cidadania acerca da tensão entre liberdade e justiça social, ou seja, o conflito entre a riqueza e a cidadania refletida na preocupação em como tornar mais iguais os desiguais do sistema capitalista. É formada por três elementos constitutivos: o civil que engloba os direitos inerentes à liberdade individual; o político que engloba o direito à participação no exercício do poder político e o social que engloba o direito a um mínimo de bem estar econômico e de segurança. Assim como, o direito da completa participação na herança social e de ter uma vida de um ser civilizado de acordo com os padrões que prevalecem na sociedade. Nessa concepção clássica de cidadania, o Estado é o provedor por meio de seus aparelhos como os tribunais de justiça, o parlamento e os serviços de educação e social e se aponta para a possibilidade do Estado fazer uso da coerção a fim de garantir a realização das condições de cidadania. Portanto, no caso dos direitos sociais, a provisão do Estado se daria por meio de um mínimo garantido, ou seja, o Estado garante um mínimo de certos bens e serviços essenciais, tais como assistência médica, moradia, educação, ou uma renda nominal mínima. 
culturais), acabaram por comprometer a existência de uma cultura cívica, culminando com o comprometimento do exercício dos direitos políticos.

Com essas características presentes no contexto político, social e cultural brasileiro, é imprescindível observar a importância da criação e manutenção de condições estruturais democráticas, onde estão as fundações do conceito de cidadania, assim como, a emergência de novos sujeitos sociais que criem e agilizem uma nova e inovadora cultura política.

O exercício da cidadania ativa pressupõe uma sociedade civil partícipe com possibilidade de criação, transformação e controle sobre o poder e/ou poderes. Existem as dificuldades da representação e os preconceitos contra a participação da sociedade civil numa democracia direta. Isso contribui para a visão da cultura como grave obstáculo à legitimação dos instrumentos de participação popular, isto é, a cultura do povo, sua mentalidade e seus valores se opõem à igualdade, não somente à igualdade política, mas a própria igualdade das condições de vida (NOGUEIRA, 2004). Também na perspectiva de BENEVIDES (1996), para o surgimento e consolidação de uma cidadania ativa, existem as chamadas dificuldades de representação, os preconceitos contra a participação da sociedade civil numa democracia direta e a importância dos costumes como grave entrave à legitimação dos instrumentos de participação.

A cidadania ativa apropria-se da redefinição da idéia de direitos, cujo ponto de partida é a concepção de um direito a ter direitos. Portanto, não se limita a conquistas legais ou ao acesso a direitos previamente definidos, ou à implementação efetiva de direitos abstratos e formais. Ela inclui, fortemente, a criação de novos direitos, que emergem de lutas específicas e da sua prática concreta. Exemplificando esses novos direitos, podemos ressaltar o direito a um ambiente saudável, o direito à moradia e o direito à efetiva participação política. No dizer de NOGUEIRA (2004), a cidadania ativa requer a constituição de sujeitos sociais ativos, definindo o que eles consideram ser os seus direitos e lutando pelo seu reconhecimento.

E. Jelin; M. A. Nogueira; M. L. Manzini Covre e R. Putnam discutem que, para a consolidação de tal cenário, é necessário envolver um processo de aprendizado social, de construção de novas formas de relação inserindo tanto a constituição de cidadãos enquanto sujeitos sociais ativos, quanto um aprendizado de convivência com esses cidadãos emergentes, que se recusam a permanecer nos lugares socioculturais que foram definidos 
para eles. Levantamos o debate se os recém instituídos espaços públicos estão preparados para receber e promover esse aprendizado e se essa nova sociedade civil está preparada para debater com o Estado sobre essas questões; já que a cidadania ativa pode-se constituir em um quadro de referência complexo e aberto para dar conta da diversidade de questões emergentes na sociedade brasileira: da igualdade à diferença, da saúde aos meios de comunicação em massa, do racismo ao aborto, do meio ambiente à moradia.

Na perspectiva de JELIN (1994), adotamos o conceito de cidadania baseado na definição legal dos direitos e obrigações que a constituem, com a sugestão de dois eixos de análise, considerando a natureza dos sujeitos e o conteúdo dos direitos. Consideramos o exame da idéia de compromisso cívico, centrado na participação ativa, no processo público e nos aspectos simbólicos e éticos. Esses preceitos estão fundados em inclinações subjetivas que conferem um sentido de identidade e de pertencimento a uma coletividade, ou seja, aquilo que promove a consciência de ser um sujeito, com direito a ter direitos.

Em nosso entendimento, a sociedade civil brasileira pode estar em um momento de transformação sociopolítica e cultural, particularmente, no que diz respeito à forma como uma parcela dessa sociedade tem se apropriado do conceito de cidadania. R. Putnam abre as discussões sobre o conceito de comunidade cívica, isto é, a existência de participação e igualdade política, solidariedade, confiança, tolerância e estruturas sociais de cooperação, que levaria ao desenvolvimento de organizações e práticas sociais eficazes.

Essa análise foi realizada, na década de 1970, através da experiência italiana na criação dos seus novos governos regionais. R. Putnam verificou a prática da comunidade cívica entre os cidadãos de alguns governos regionais, mais especificamente, os localizados na região norte da Itália, considerada a mais desenvolvida política e economicamente, ao contrário dos governos regionais da região sul. Assim, ele analisa as questões sobre o autoritarismo e as relações de dominação/dependência em contraposição a um ethos de democracia/participação. Nesse ponto, podemos encontrar semelhanças no caso da sociedade brasileira, com a existência de locais onde se pode encontrar essa mesma relação. Entretanto, com diferenças geográficas pontuais (SANTOS, M., 1993; 1991), sendo o sul mais desenvolvido política e economicamente do que o norte do país.

Nos governos regionais menos cívicos, a política se caracteriza por relações verticais de autoridade e dependência. Os líderes políticos são oriundos de um segmento estreito da 
hierarquia social, são céticos em relação à capacidade de discernimento dos cidadãos e entendem que precisa existir uma liderança forte por parte das elites tradicionais. Os cidadãos vêem a coisa pública como problema alheio, dos detentores do poder e não da sociedade civil, que tem, na sua maior parte, a apatia e a negação. Logo, têm poucas oportunidades para reversão desse quadro.

Ao contrário, a atitude cívica está estreitamente ligada com a igualdade e a participação ativa. As atitudes da elite e das massas são, na realidade, dois lados de uma mesma moeda e se combinam num equilíbrio que se reforça mutuamente. Portanto, essa atitude implica direitos e deveres iguais para todos, unida por relações horizontais de reciprocidade e cooperação.

Cidadãos de uma comunidade cívica buscam o interesse próprio, definido no contexto das necessidades públicas gerais, o interesse próprio que é sensível aos interesses dos outros. Característica intrínseca da comunidade cívica é a questão do respeito à diferença e a confiança em seus membros, o respeito às regras e a certeza de que os outros agirão da mesma forma. Virtude cívica implica em honestidade, confiança e observância das leis. Salienta-se a importância de instrumentos sociais de cooperação para incorporar e reforçar as normas e os valores da comunidade cívica. A comunidade cívica apresenta tendência a constituir organizações civis e políticas, enfim, a ser o berçário de novas organizações e práticas sociais.

As considerações oriundas dessa corrente de autores, especialmente de R. Putnam, vêm de encontro à realidade social, cultural e política do Brasil, colocando-nos frente à outra face conceitual da cidadania, estreitamente ligada às raízes históricas do autoritarismo, do clientelismo e do coronelismo e vinculada ao próprio sentido da cultura política da dádiva e da benesse. Por isso, frente a esse quadro, perguntamo-nos se será possível a emergência de novas organizações e práticas sociais, respaldadas pela atuação de novos sujeitos sociais.

SALES (1994), observa que essa particularidade brasileira é condicionante do que se denomina de cidadania concedida e está na gênese de sua construção. Esse processo está vinculado à não-cidadania da sociedade civil, dependente das benesses da elite, detentores do monopólio privado do mando, características da cultura política brasileira ainda hoje observadas. Em nosso ponto de vista, esse contexto pode estar passando por mudanças. 
Entretanto, permanece o vínculo da dependência pessoal para com quem atualmente detém o poder. Ou seja, de certa forma o exercício dos direitos pelos cidadãos ainda se dá por meio de um sistema de relações pessoais ou de uma prática clientelista.

Na perspectiva de PUTNAM (1996) e MANZINI-COVRE (1994), consideramos que é possível a convivência mútua dos dois processos anteriores, possibilidade justificada pelo quadro brasileiro de emergência de novos sujeitos sociais, ao mesmo tempo em que persiste o de apatia política de uma parte da sociedade brasileira.

MANZINI-COVRE (1994) discute essa questão partindo do princípio do uso do espaço permitido pela democracia sob o capitalismo, possibilitando, conjuntamente, a atuação de sujeitos sujeitados e sujeitos para liberdade.

Nessa abordagem, temos o plano dos sujeitos sujeitados, relativo ao desenvolvimento da sociedade e cultura de massas. Esse processo promove um tipo de igualdade passiva, pois o cidadão sente-se impotente ou não está sensível às questões que afetam a comunidade, transferindo toda a responsabilidade social e política para o Estado ou seus representantes. Assim, deixa-se comandar e vê-se em um esquema de cidadania passiva, desmobilizadora, isto é, da não-cidadania, carreando, conseqüentemente, um ethos de pessimismo e impotência para promoção de mudanças fora dos limites dos interesses das elites.

O plano dos sujeitos para a liberdade considera a inovação na participação da sociedade civil por meio de formas representativas como ONG's, movimentos sociais, experiências de auto-gestão local etc. É movimento cultural de uma atividade política, com uma nova concepção, atravessada pela solidariedade e pela aceitação das diferenças ou da heterogeneidade, onde os objetivos e desejos dos indivíduos, como subjetividades específicas, também são considerados, ao lado dos objetivos e desejos coletivos.

Destacamos semelhanças entre a conceituação de cidadania ativa e a da comunidade cívica e, nesse momento, indagamo-nos se alguns desses processos poderiam encontrar terreno fértil para vicejar em terras brasileiras, se os recém instituídos espaços públicos e os instrumentos sociais de cooperação podem fazer o papel de "incubadoras" para novas práticas sociais, ou se a atuação da cidadania concedida, ou ainda a dos sujeitos sujeitados, estariam tão enraizadas na cultura política brasileira que dificultariam o início dessa transformação democrática. 
Por conta disso, conjeturamos se o atual contexto sócio-político brasileiro pode estar fomentando a emergência de uma nova sociedade que incorpore características da sociedade contemporânea como o papel das subjetividades; a atuação de sujeitos sociais de novo tipo, reivindicando direitos de novo tipo e a ampliação do espaço da política que são estratégias que reconhecem e enfatizam o caráter intrínseco e constitutivo da transformação cultural para a construção democrática. A construção dessa cidadania ativa apontaria para a constituição e difusão de uma cultura democrática.

Contudo, consideramos que ainda estão profundamente enraizados na cultura brasileira, os critérios de classe, raça e gênero, evidenciando um sistema de classificações e estabelecendo diferentes categorias de sujeitos, dispostos nos seus respectivos lugares na sociedade. Quadro que produz formas de sociabilidade e uma cultura autoritária de exclusão que subjaz ao conjunto das práticas sociais e reproduz a desigualdade nas relações sociais em todos os seus níveis. Assim sendo, seu desaparecimento constitui um importante desafio para a efetiva democratização da sociedade.

A minimização e reversão desse processo são imprescindíveis para a democratização da sociedade, criando um ambiente propício para uma maior abrangência e fortalecimento da cidadania ativa, que reafirma a idéia de ser uma categoria estratégica, especialmente, ante a possibilidade de construção de novos conteúdos, agilizados no desenvolvimento das frágeis formas fragmentárias provenientes dos movimentos sociais.

Se a emergência de novos sujeitos sociais for transformada em novas organizações e práticas sociais concretas, poderemos considerar o que diz NOGUEIRA (2004) sobre a importância desses sujeitos para a democracia. É imprescindível a emergência de espaços públicos como uma forma de mobilizar esses sujeitos pela educação, pelo debate público, pela multiplicação de espaços institucionais de discussão e deliberação. A política democrática não pode ser concebida sem participação, representação e institucionalização. Somente é possível admitir um Estado soberano a partir da concomitante admissão de um povo soberano. Assim, a cidadania ativa corrobora para a afirmação e construção da democracia participativa, que pressupõe uma combinação entre cidadania democrática e representação política plena.

Do ponto de vista de SANTOS (2002), se a construção da democracia se faz pelo constante confronto entre a democracia possível e a abertura de espaços democratizantes 
articulados, uma nova dinâmica poderá fazer avançar o processo. Será preciso associar a prática da cidadania ativa a uma nova concepção de representação política, para transformar o Estado privatizado pelo patrimonialismo.

Na perspectiva de ARATO (2002), para além da discussão sobre a importância da abertura de novos espaços e novos sujeitos sociais que construam e fortaleçam a democracia participativa ou deliberativa, é mister debater de que não há dentro de um modelo puramente deliberativo de democracia garantias institucionais de que os interesses públicos não sejam usados de modo meramente retórico e que as contribuições da sociedade civil sejam seriamente consideradas pelo poder público. Além disso, para o autor não basta decretar as normas mais relevantes para que sejam institucionalizadas, elas precisam também ser cumpridas. Assim como, assumindo que todos os direitos relevantes estejam institucionalizados, e, portanto, sejam garantidos, nenhum modelo institucional pode garantir que os sujeitos sociais realmente se organizem, participem da discussão pública e envolvam-se com a política.

Questionamos, assim, se, no Brasil, esses espaços públicos recém institucionalizados, mesmo com a possibilidade de atuação dessa emergente sociedade civil, estão tendo a possibilidade de desempenhar esse importante papel de transformação da face patrimonialista e autoritária, características do Estado brasileiro.

\subsection{Os Novos Movimentos Sociais}

Para contextualizar os novos movimentos sociais (NMS), partimos, de um brevíssimo histórico do surgimento no Brasil dos movimentos sociais tradicionais, ou velhos movimentos sociais. Os movimentos sociais tradicionais surgiram no contexto da sociedade industrial, dividida em classes sociais, com o proletariado submetido ao mundo da produção e exploração de sua força de trabalho. Esses movimentos expressavam essa contradição fundamental e o desejo de sua superação, trazendo em seu bojo o projeto de uma sociedade sem classes. São como o momento de integração da práxis com o projeto através de uma organização grupal, buscando a transformação voltada para os mesmos objetivos, sob a orientação, mais ou menos consciente, de princípios valorativos comuns e sob uma organização diretiva mais ou menos definida. 
Os movimentos sociais tradicionais tiveram como corrente filosófica, teórica e ideológica quase que, exclusivamente, o marxismo-leninismo, o orientador fundamental dos principais movimentos sociais do final do século XIX e da primeira metade do século XX (SCHERER-WARREN, 1987). No Brasil, especialmente àqueles reivindicatórios urbanos refletiam a presença do antagonismo e a multiplicação dos espaços diversificados de ação e de desafio ao Estado. Representam, a possibilidade de constituição de uma identidade social ou política e a explicitação de demandas relativas à reprodução social dos setores mais excluídos das cidades e metrópoles (JACOBI, 1989).

Com relação a sua constituição, os movimentos sociais tradicionais são, em sua maioria, homogêneos em termos socioeconômicos e culturais, direcionam-se a problemas sociais particulares imediatos e localizados, que afligem diretamente seus participantes. Do ponto de vista de COSTA (1997), surgem no vácuo existente entre os atores da esfera pública (porta-vozes de partidos, grupos organizados, interesses econômicos) e público (sociedade civil). Assim, quando a sociedade civil se dá conta que os temas que lhe interessam não estão recebendo o tratamento adequado pelos sujeitos da esfera pública, organizam-se na busca da atenção pública para suas questões.

Particularmente no que diz respeito aos NMS são, em sua maioria, heterogêneos em termos socioeconômicos e culturais e direcionam-se a questões mais amplas que afligem a sociedade como um todo, como as questões ambientais, de gênero, da fome, da violência urbana etc. Levanta-se o debate de que esses movimentos são organizações sociais capazes de modificar substancialmente as práticas sociais existentes no Brasil. Também possuem, no Brasil, características muito específicas, o que os diferencia e particulariza a sua análise frente a esses movimentos nos países capitalistas avançados.

Os autores mais expressivos que discutem os NMS dessa perspectiva são B. S. Santos; I. Scherer-Warren; P. J. Krischeke. A partir desse ponto de vista, consideramos que as características sociopolíticas, econômicas e culturais que sempre pautaram a vida da sociedade brasileira como o autoritarismo e o caráter elitista da democracia, pedem que esse debate não seja generalizado aos mesmos movimentos localizados nos países capitalistas avançados. Pois, no Brasil, combinam-se, nesse processo: movimentos semelhantes aos típicos dos países centrais, como o movimento ambiental e feminista, 
ainda que as reivindicações concretas sejam distintas, com movimentos próprios orientados para a reivindicação da democracia e das necessidades básicas.

Contrapondo essa tendência de debate, autores como R. Dalton \& M. Kuechler e A. Scott, que dialogam com os NMS atuantes nos países capitalistas avançados, propõem uma análise mais generalista dos NMS. DALTON, R. \& KUECHLER, M. (1990) definem os NMS como um movimento de um setor significativo da sociedade, que desenvolve e define interesses incompatíveis com a ordem política e social existente e que os persegue por vias não institucionalizadas, invocando, potencialmente, o uso da força física ou da coerção. Nos países capitalistas avançados, a enumeração dos NMS inclui os movimentos ecológicos, feministas, pacifistas, anti-raciais, de consumidores, de auto-ajuda etc.

No Brasil, os NMS são muito mais amplos e heterogêneos, abrangendo realidades societárias tão diversas que, o que delas se diz numa análise generalista é muito pouco e, assim, o debate não pode ser reduzido a um único conceito ou a uma única teoria sociológica. Assim, destacamos como NMS, além dos movimentos ecológicos, feministas, pacifistas, anti-raciais etc., uma parcela dos movimentos sociais urbanos, como as Comunidades Eclesiais de Base organizadas, movimentos dos sem-terra, o novo sindicalismo urbano e rural, movimentos de jovens, entre outros.

Além da inclusão desses movimentos na organização dos NMS brasileiros, também devemos enfatizar as diferenças significativas em termos de objetivos de ideologia e de base social entre esses movimentos nos países capitalistas avançados e do Brasil. No dizer de SANTOS (2001), em contraste com o que acontece nos países capitalistas avançados, a particularidade do Brasil, é de que não existem movimentos sociais puros ou claramente definidos, frente a várias dimensões, não somente nas relações sociais, mas dos próprios sentidos da ação coletiva. Essa afirmação, quando discorre sobre a probabilidade de um movimento de orientação classista ser acompanhado de juízos étnicos e sexuais, diferenciando-o e assimilando-o a outros movimentos de orientação culturalista com conteúdos classistas. Do ponto de vista dos projetos e dos tipos de reinvidicação, existe uma identidade apenas parcial entre os países centrais e os países semiperiférios ou de desenvolvimento intermediário, como o Brasil.

Pode-se encontrar essa identidade, sobretudo, nos movimentos ambientalistas, pacifistas e feministas. Essa parcialidade se explica, pois no Brasil, ainda não são atendidas 
muitas das necessidades básicas dos indivíduos, assim como os direitos mínimos de cidadania. Logo, os NMS voltam-se para as reivindicações dessa natureza, que, nos países capitalistas avançados, podem ser consideradas como antigas, ou superadas.

O debate hoje tende a afirmar que a identidade dos NMS é construída a partir de duas constatações do tecido social. A primeira é que a sociedade passa a reconhecer as condições materiais do capitalismo contemporâneo e de suas variadas e sobrepostas formas de opressão, bem mais amplas do que os antagonismos que ocorrem no mundo das relações de produção. E a segunda é a internacionalização de uma cultura crítica, que vem penetrando os movimentos populares (SANTOS, 2001; PONTE, 1990; SCHERER-WARREN, 1987).

A partir disso, entendemos que, diferentemente da ocasião da emergência dos movimentos sociais tradicionais, os NMS são gestados no bojo dos problemas decorrentes das transformações no modo de vida, que não afetam somente a população mais pobre, ou uma categoria de classe, mas também outros grupos sociais. Esse contexto proporciona aos NMS heterogeneidade e diversidade, como o movimento ambientalista, feminista, de negros etc, podendo configurar a formação de uma nova cultura política. Essas são importantes questões estruturais fundamentais do mundo contemporâneo que perpassam pelos NMS. Assim, autores como B. S. Santos; I. Scherer-Warren; P. Jacobi; R. de La Cruz e S. Costa levantam a discussão de que, no Brasil, os NMS são uma resposta autoorganizada da sociedade civil aos modelos culturais, políticos e econômicos hegemônicos.

Essa ruptura cultural parecia relevante, na medida em que o modo de vida urbano intensivo na replicação das rotinas alienadas e alienantes da família, vai induzindo o esgarçamento dessa unidade societal, no bojo da qual aparecem as crises da família, dos casais, das relações entre pais e filhos, da dupla jornada de trabalho da mulher e da perda de fé nas crenças tradicionais. Além disso, a sociedade ressente-se com a sua própria individualização e com o respectivo isolamento das pessoas. Como conseqüências mais aparentes desse trauma social, os primeiros movimentos que saem em busca de respostas são setores dos movimentos de jovens e os movimentos feministas.

Por sua vez, a ruptura do modelo estatal era fundamental em vista da crise econômica e da complexidade da sociedade urbano industrial que assinalaram os limites para o funcionamento do Estado interventor e desenvolvimentista: não havia condições fiscais de favorecimento ao investimento público em infra-estrutura urbana; o aparelho burocrático, 
além de dispendioso, demonstrava incapacidade técnica e incúria com a aplicação do dinheiro público; e o centralismo decisório emperrava ou mesmo obstaculizava a iniciativa alheia de resolução das questões prementes da vida social, ainda que na esfera de uma pequena comunidade. De forma mais precisa, pode-se dizer que os elementos de crise do modelo estatal se resumem em três pontos: a ineficiência administrativa; a incapacidade para prestar serviços; a deterioração da legitimidade.

Por fim, a ruptura do modelo de desenvolvimento se fazia mister, se observados os fatores estruturais da crise econômica, os quais tornavam recorrentes e cada vez mais prolongados, os períodos de recessão, desemprego em massa, altas taxas de juros, dentre outros. Concomitantemente, evidenciam-se os efeitos ambientais perversos da industrialização, como a poluição hídrica e atmosférica, os riscos tecnológicos etc. Assim, os movimentos ambientalistas, cooperativistas, pacifistas e antinucleares são os exemplos de NMS que representam a reação a essa ruptura.

Um dos debates que geram uma grande controvérsia de opiniões, particularmente no Brasil, é sobre o ineditismo dos NMS. Autores como A. G. Frank; M. Fuentes e P. Jacobi discutem se esses movimentos são realmente uma novidade. Esse debate ocorre, tanto nos países capitalistas avançados, quanto no Brasil, onde esses autores analisam os NMS como uma continuidade dos velhos movimentos sociais. Os NMS seriam a continuidade dos velhos movimentos ecológicos, pacifistas, feministas do século XIX e dos movimentos anti-raciais, tanto dessa época quanto dos anos cinqüenta e sessenta do século $\mathrm{XX}$. Ou, ainda, portadores de reivindicações que foram parte integrante dos movimentos sociais tradicionais - o movimento operário e o movimento agrário ou camponês. Por último, corresponderiam a ciclos da vida social e econômica e, por isso, por ser recorrente, a sua novidade seria somente aparente.

Essa perspectiva da organização dos NMS entende que os pontos fundamentais de sua análise devem ser os modos de mobilização de recursos organizativos entre outros e não a sua ideologia. Logo, o impacto procurado por esses movimentos é, em último caso, político e a sua lógica prolonga a da cidadania que orientou os movimentos sociais do passado. A distância desses movimentos ao Estado é mais aparente do que real, pois as reivindicações globais e locais acabam sempre por se traduzir numa exigência feita ao Estado, nos termos em que o Estado se sinta na contingência política de ter de lhe dar 
resposta. Para JACOBI (1997), o respaldo dessa tese seria que, os NMS, por vezes, jogam o jogo da democracia representativa, ainda que seja pelo lobbying e pela via extraparlamentar e fazem alianças oficiais, ou não, com sindicatos e partidos, quando não se transformam eles mesmos em partidos.

Outro grupo de autores como B. S. Santos; E. Viola \& S. Mainwaring; I. SchererWarren e V. da S. Telles pensam os NMS como um movimento inédito, tanto na forma de sua constituição e organização, quanto na forma de resposta aos modelos culturais, políticos e econômicos impostos ao país. VIOLA \& MAINWARING (1997) consideram que o ineditismo dos NMS estaria em que não apenas havia insuficiência de atuação política da sociedade civil, tanto para lidar com as questões tradicionais quanto para lidar com questões atinentes das formas de outros níveis de existência social.

Os NMS são inéditos e a sua novidade estaria na abordagem original dos conflitos e contradições do mundo moderno, que reorganiza a sociedade civil de uma forma absolutamente nova, fora dos recortes corporativos, classistas, étnicos, enfim, tradicionais, entretanto, não vemos ainda, suficiência desses movimentos para lidar eficazmente com as consequiências socioambientais, culturais, econômicas e políticas desses conflitos e contradições.

Observamos que essa abordagem original estimulou a reorganização da sociedade civil para lidar com esses níveis de uma forma mais abrangente, açambarcando preocupações das relações de gênero, dos temas ambientais, entre outras questões. A novidade desses movimentos também se justificaria por conta de o tecido do grupo constituinte dos NMS ser transversal a sua forma tradicional setorizada, na sua insuficiência em lidar com questões atinentes: no movimento ambiental, por exemplo, cabe a questão relativa à poluição que imbricou o modo de vida dos diversos segmentos da sociedade ou de seus estratos, ricos e pobres, homem e mulher, brancos e negros, que podem se encontrar nessa arena de embate, organizar e reivindicar.

Assentimos com a discussão levantada por SANTOS (2001) sobre o ineditismo dos NMS de que constituem, tanto como crítica à regulação social capitalista quanto como crítica à emancipação social socialista, tal como ela foi definida pelo marxismo. Identificam novas formas de opressão, que extrapolam as relações de produção e, além disso, nem são oriundas delas, como a guerra, a degradação ambiental, o racismo, as relações de gênero 
etc. Assim, pelo fato de buscarem um novo paradigma social, com menor ênfase na riqueza e no bem-estar material, voltando seu olhar para a cultura e qualidade de vida, os NMS denunciam, com radicalidade, os excessos de regulação da modernidade. Esses excessos atingem, não somente o modo como se trabalha e produz, mas também,

o modo como se descansa e vive; a pobreza e as assimetrias das relações sociais são a outra face da alienação e do desequilíbrio interior dos indivíduos; e, finalmente, essas formas de opressão não atingem especificamente uma classe social e sim grupos sociais transclassistas ou mesmo a sociedade no seu todo (SANTOS, 2001, p: 258).

Essa seria a maior novidade desses movimentos, a de ser fruto das conseqüências do modelo de desenvolvimento adotado pelo país, que levou ao agravamento da situação política e econômica, ao distanciamento nas relações interpessoais e à degradação ambiental. Esse momento passa a ser entendido pelos NMS como parte de um processo que não pode ser discutido e combatido isoladamente. Conseqüentemente, são fundamentais para levantar o debate acerca das questões urbanas mais prementes por conta das quais sofrem a maioria dos municípios brasileiros, desassistidos de importantes instrumentos de infra-estrutura urbana como habitação, saúde, educação e direitos humanos fundamentais e de um meio ambiente equânime, ainda que esse debate se dê de forma fragmentária e dispersa, assim como, são instáveis e frágeis as conquistas disso alcançadas.

Por fim, há o debate de que o ineditismo se comprovaria também na atuação dos NMS como sujeitos importantes nos esforços para definir a democracia, questionando a cultura política semidemocrática preponderante no Brasil, emergindo na arena política com novos valores, métodos, abordagens e perspectivas (TELLES, 1994; VIOLA \& MAINWARING, 1997), sendo os recém instituídos espaços públicos de participação e deliberação a arena onde essa atuação pode se dar.

A tendência desse debate atual sobre os NMS é a de que a sua contribuição para a democratização certamente não será aquela que cabe a sujeitos como sindicatos ou partidos políticos. As contribuições democratizantes desses movimentos não podem ser enxergadas unicamente a partir das instâncias institucionais, esperando partir daí o aperfeiçoamento dos mecanismos de intermediação de interesses ou a renovação da vida partidária, no caso do Brasil, esvaziada pelas velhas práticas autoritárias e pelos novos casuísmos. Suas possibilidades residem precisamente em seu enraizamento em esferas sociais que são, do 
ponto de vista institucional, pré-políticas. E é no nível de tais órbitas e da articulação que os NMS podem estabelecer e de outros espaços institucionais que podem emergir os impulsos mais promissores para a construção da democracia.

Consideramos que as experiências, fruto dos movimentos sociais e de seus resultados concretos, apesar de localizados, mostram algumas coisas importantes. Essas experiências podem ser tomadas como registros de uma sociedade civil emergente, isto é, na qual as relações sociais são mediadas pelo reconhecimento de direitos e representação de interesses, de tal forma que se torne possível a construção de espaços públicos que confiram legitimidade aos conflitos nos quais, a medida de equidade e a regra de justiça venham a ser alvo do debate e de uma permanente negociação. É na dinâmica dessa nova sociedade civil que uma noção plural de bem público pode ser construída, assim como, coube uma pluralidade das opiniões, visibilidade dos conflitos e das diferenças e deu-se legitimidade aos interesses e aspirações mais diversos.

A análise das questões da participação política da sociedade civil em espaços públicos, da cidadania e dos NMS é complexa e pode nos levar a muitos caminhos. Por essa complexidade, não podemos dar conta desse tema com análises generalistas, assim como também nos questionamos a respeito da possibilidade dessa novidade tornar-se um motor para a transformação da face social, ambiental, política e cultural do Brasil. Questionamos se existe a possibilidade dos NMS realmente levarem esses novos sujeitos sociais a constituírem novas organizações e novas práticas sociais realmente eficazes, especialmente no que diz respeito àquelas que levem à qualidade socioambiental urbana. Ou seja, se essas novas organizações sociais podem ser instrumentos para práticas sociais mais conscientes em relação ao meio ambiente, principalmente, no que tange aos nossos recursos hídricos.

Propomo-nos, então a discutir a relação entre os recém criados espaços públicos e as práticas no interior destes. Discutimos se essas novas organizações sociais podem fomentar práticas socioambientais eficazes, ou ainda, se o desenho institucional dessas organizações permite a efetiva participação de todos os diversos segmentos da sociedade civil.

Investigamos essas questões a partir do estudo de caso de um espaço público institucionalizado, especificamente, o Orçamento Participativo (OP). O local em que essa prática se instaura nesse momento é o município de São Carlos, estado de São Paulo. E para tal investigação faremos uso de ferramentas metodológicas qualitativas e quantitativas, 
como observação direta, aplicação de questionários, entrevistas e análise de demandas, durante os anos de 2001 a 2004. Porém, antes da particularização desse estudo de caso, partiremos, no Capítulo 2, para uma melhor compreensão de um NMS específico, ou seja, o movimento ambiental e como se dá o seu debate com as questões urbanas mais urgentes. 


\section{Capítulo 2 - Meio ambiente e participação}

\subsection{O movimento ambiental brasileiro}

O movimento ambiental brasileiro tem sido entendido como sendo fruto do processo de reação de parcela da sociedade civil que almejava a ruptura do modelo de desenvolvimento imposto ao país. Esse modelo levou aos fatores estruturais da crise econômica, cujas conseqüências mais visíveis são o desemprego em massa, as altas taxas de juros, os problemas de infra-estrutura urbana, aliados aos impactos ambientais negativos que se tornam cada vez mais evidentes, exemplificados pela poluição hídrica e atmosférica, pelo inchaço urbano, pelos riscos tecnológicos, entre outros. Essas seriam as principais razões pelas quais o movimento ambiental no Brasil teve, basicamente, como celeiro os grandes centros urbanos.

Sobre o surgimento e evolução do movimento ambiental global e, particularmente no Brasil, destacamos autores como E. J. Viola; H. Leis e P. F. Vieira que levantam o debate de que este, inicialmente, transitou por alguns poucos segmentos da sociedade civil, passando, posteriormente, a sofrer modificações e a ampliar seu diálogo com um número maior de segmentos da sociedade. Com suas idéias iniciais restritas a uma oposição genérica à sociedade injusta, desigual, predatória e imediatista, posteriormente passa a propor um novo projeto de sociedade, por isso, o consideramos um NMS, principalmente por conter características comuns aos outros movimentos como sua atuação descentralizada 
e multiforme, heterogeneidade em sua constituição, voltada para um trabalho em rede e pulverizada pelo mundo.

A parcela do movimento que evoluiu dessa forma é cada dia mais significativa, com grande visibilidade pública e influência crescente sobre seus parceiros, pois se reconhece como um sujeito social, portador de um projeto de sociedade. Tal promessa de universalidade o transforma em um movimento multissetorial que penetra o governo, a academia, o empresariado, além de outros NMS (LEIS, 1999; LEIS \& VIOLA, 1996).

Assentimos com o debate de E. J. Viola; H. Leis e P. F. Vieira, onde essa singularidade só é possível, porque as próprias questões ambientais pedem a sua existência, haja vista que envolvem trocas e negociações entre dimensões e sujeitos diferentes, ou seja, implica a tomada de decisões em contextos que envolvem problemáticas, paradigmas e conceitos que, por vezes, parecem contraditórios. As questões ambientais são complexas, assim, para sua discussão e resolução, é imprescindível o sincretismo e o encontro entre a ciência, a religião, a arte, a filosofia e a sabedoria popular. Da mesma forma, a ação política no interior do movimento ambiental, é complexa, com incertezas, antagonismos e/ou parcerias, trocas, negociações, possibilitada pelo seu próprio caráter heterogêneo, pois, por um lado, comporta em seu interior propósitos conservadores e, por outro, revolucionários.

Observamos também a tendência de análise de E. J. Viola; H. Leis e P. F. Vieira de que essa é uma característica única, ou seja, um movimento social em cujo interior se encontra a diversidade de segmentos sociais, políticos e culturais e que trabalham por um objetivo comum, explicando o fato de casos em que: (a) alguns valores orientam a ação para conservar a diversidade biológica e nossas heranças culturais; (b) outros a orientam para revolucionar as relações sociais e políticas existentes. Essa via de mão dupla, por onde se caminha para conservar ou revolucionar, é uma contradição, se observada do ponto de vista racional instrumental. Todavia, a complexidade das questões ambientais pede numerosas trocas e negociações entre os diversos sujeitos sociais e políticos envolvidos. Do ponto de vista de LEIS (1999), as finalidades da política ambiental, que pedem para conservar algumas coisas e ao mesmo tempo revolucionar outras, orientam para a necessidade da negociação, através do diálogo e não apenas da usual forma instrumental. Por conseguinte, é natural que as políticas do movimento ambiental combinem orientações, tanto a favor de privatizações quanto de nacionalizações. Do mesmo modo, sejam 
favoráveis a aumentar as despesas do Estado em algumas áreas e diminuí-las em outras, ou de liberar o mercado para alguns produtos e regulá-lo para outros.

Consideramos que essa característica singular do movimento ambiental explica-se não somente pela heterogeneidade político-social-cultural de sua composição, como também pelas características holísticas das questões ambientais. Particularidades que levaram o movimento ambiental a ir gradativamente evoluindo em seu discurso e ações, a interessar-se não somente pelos seus temas específicos, como também pelo conjunto dos problemas sociopolíticos atuais.

Assim, corroboramos com a tendência de debate de E. J. Viola; H. Leis e P. F. Vieira de que a política do movimento ambiental não deve ser entendida como restrita a determinados objetivos, pois a complexidade, tanto fruto da diversidade de sua composição como de suas questões, levou os sujeitos participantes a terem que se envolver também na produção dos meios técnicos, políticos e culturais, em sentido amplo para sua realização. Decidir sobre uma política ambiental supõe também a imposição de certos valores e idéias sobre o que está certo e errado. Uma política destinada a enfrentar um problema de poluição leva, por exemplo, a ter que decidir sobre complexos temas político-éticos de justiça distributiva.

Essa tendência de abordagem da questão ambiental necessita da contenção de suas causas estruturais, envolvendo mudanças de mentalidades, valores e atitudes, para além do processo científico, de políticas preventivas e da institucionalização de espaços públicos de discussão e deliberação. Entendemos também que esta seria uma das razões de grande parte dos sujeitos atuantes no movimento ambiental fazer uma clara opção a favor da democracia. Nesse caso, à democracia participativa, ao exercício da cidadania ativa, onde se efetiva o processo de formação de vontade pública consistente e efetiva, a partir de uma participação política de tipo horizontal. 


\subsection{Breve histórico da evolução do movimento ambiental no Brasil}

Até a década de 1960, a abrangência do movimento ambiental brasileiro era restrita a alguns poucos segmentos da sociedade civil. Somente a partir do final da década seguinte, tem inicio seu crescimento, fruto de sua renovação estrutural. Nesse processo, o preservacionismo e o conservacionismo, que antes dominaram as campanhas ambientalistas, foram revitalizados por uma expressão que combinava as preocupações estéticas e científicas com as sociais.

Pela característica político-social-cultural brasileira, o movimento ambiental surgiu e evoluiu a partir de uma dialética entre a sociedade civil e o Estado. Essa particularidade se justifica, pois, no Brasil, não existia uma forte preeminência e a antecedência histórica do papel das organizações não-governamentais (ONG's), como o caso do ambientalismo em outros países, principalmente, do Hemisfério Norte. Inicialmente, o movimento ambiental brasileiro foi influenciado pelo que acontecia nesse Hemisfério, por isso, alguns dos movimentos dessa época consideravam como mais graves os problemas do Hemisfério Sul como o aumento da população ou desaparecimento das florestas tropicais, ao invés do modelo de consumismo ou de uso intensivo de combustíveis fósseis do Hemisfério Norte.

Destaca-se que, no fim dos anos de 1960 e início dos anos de 1970, o debate sobre as questões ambientais volta-se mais para as posições radicais. As teorias neomalthusianas e

de crescimento zero da economia ganham força, frente às ameaças à sobrevivência da espécie humana. Nessa fase, o ambientalismo radical e as posições mais estéticas tinham em comum o fato de serem apolíticos. Isso porque a "síndrome do apocalipse" gerava sérios entraves para uma verdadeira ação política, tanto quanto as soluções voluntaristas e individualistas de seus críticos, ou seja, a questão ambiental ainda não tinha penetrado o tecido político das sociedades (LEIS, 1999; LEIS \& VIOLA, 1996).

Nesse contexto, o movimento ambiental brasileiro começa a se organizar e sua atuação passa a concentrar-se nas denúncias e na conscientização política sobre a degradação ambiental local. Iniciam-se as campanhas de âmbito nacional como contra o desmatamento da Amazônia, a construção de usinas nucleares, a poluição de Cubatão etc. Concomitantemente, uma parcela do movimento ambiental brasileiro ainda é fortemente influenciada pelo movimento ambiental norte-americano e europeu. Esse fato justifica a recepção bastante acrítica da questão ambiental por parte de algumas organizações 
brasileiras, que não percebem a particularidade da deterioração ambiental do país. Um exemplo disso é a não discussão da questão do evidente déficit em saneamento básico, já que esta não estava incluída no programa ambiental norte-americano e europeu.

Em 1972, acontece a Conferência de Estocolmo, ocasião em que o governo brasileiro foi o principal organizador do bloco dos países em desenvolvimento, que mantinham uma posição de resistência ao reconhecimento da importância da questão ambiental, e cujo argumento principal era de que a pior poluição era a miséria, argumento este que ia ao encontro à política interna brasileira de desenvolvimento industrial.

Já no ano de 1973, foi instituída a Secretaria Especial do Meio Ambiente (SEMA), objetivando minorar a imagem internacional negativa que o Brasil havia criado em Estocolmo. Nesse momento, o governo brasileiro define a problemática ambiental restrita ao controle da poluição e preservação de algumas amostras de ecossistemas naturais, entendendo os recursos naturais como quase infinitos e possíveis de serem explorados rapidamente e de maneira intensa. Essa proposta se alinhava ao contexto político do país, direcionado a atingir altas taxas de crescimento econômico, ao invés de um olhar mais conservacionista, resolução do programa ambiental internacional.

Ainda, durante os anos de 1970, segmentos do movimento ambiental gradualmente começam a politizar-se, incluindo os conservacionistas, contrários a qualquer tomada de posição política. Essa mudança foi impulsionada pela incapacidade e insensibilidade do governo brasileiro que em seus três níveis não promoveu as mudanças necessárias frente à urgência de resolução das demandas socioambientais. Assim, o movimento ambiental se beneficiou desse momento histórico, envolvendo segmentos da sociedade civil, como a classe média e estudantil.

A partir desse momento, o discurso ambiental passa a levantar problemas socioambientais cuja solução nem sempre estava "afinada" com os sistemas político, econômico e social vigentes. O movimento ambiental passou então, a sugerir uma significativa mudança nos valores da sociedade, assim como, a propor mudanças na economia e nos estilos de vida. Por conta desse processo, o engajamento da sociedade civil às questões ambientais passa a ser complementar as demais questões de ordem cultural, social e/ou política. 
Essa característica marcante do movimento ambiental, que acaba por ampliar sua abrangência, é dar mais importância aos valores éticos de novo tipo do que a objetivos materiais de velho tipo (LEIS, 1999). Assim, observamos que os valores que passam a mover o movimento ambiental não contradizem os demais NMS, que começam a emergir no cenário sociopolítico brasileiro. Ao contrário, pela complexidade e amplitude de seus valores, acaba por açambarcar as principais questões contemporâneas. Por conseguinte, consideramos o debate levantado por E. J. Viola; H. Leis e P. F. Vieira de que o crescimento e abrangência do movimento ambiental estão estreitamente ligados à evolução pela qual ele passou.

Destaca-se, também, que, a partir da politização do movimento ambiental, abriu-se tanto a possibilidade da emergência dos partidos verdes quanto à institucionalização de órgãos governamentais de meio ambiente e políticas públicas em vários países, inclusive no Brasil. Nas décadas posteriores, o benefício desse momento passará para novos setores da sociedade.

Quanto ao surgimento de associações ambientalistas, a partir da década de 1980, acontece a sua multiplicação no Sul e no Sudeste, com alguma disseminação para as regiões Nordeste, Norte e Centro-Oeste. Nos primeiros momentos, essas associações têm como seu principal padrão de atuação o de denúncia da degradação ambiental.

Na segunda metade dessa década, o progressivo aumento da preocupação pública, interna e externa ao Brasil, com a deterioração ambiental transforma o movimento ambiental num movimento multissetorial e complexo. Na perspectiva de LEIS (1999) e LEIS \& VIOLA (1996), constituído por cinco setores: os movimentos e organizações nãogovernamentais ambientais; as agências estatais de meio ambiente; o socioambientalismo, constituído por ONG's e movimentos sociais; os grupos e as instituições científicas que realizam pesquisas sobre a questão ambiental; um reduzido setor do empresariado que começa a pautar seus processos produtivos e investimentos pelo critério da sustentabilidade ambiental.

Nessa mesma época, são constituídos grupos científicos dentro de universidades e institutos de pesquisa, que passam a abordar a questão ambiental de um modo interdisciplinar. A Sociedade Brasileira para o Progresso da Ciência (SBPC) atuou como 
catalisadora desse movimento, produzindo os posicionamentos referidos à questão ambiental.

A partir desse contexto, ponderamos a perspectiva de LEIS \& VIOLA (1996) de que a evolução para um movimento ambiental complexo "quebra o isolamento e a relação 'especular'” (op. cit., p. 102) que era característica desse movimento até então, perpassando a cada um desses setores que começam a trocar informações, experiências e demandas de sujeitos com dinâmicas mais profissionalizadas. Por conta disso, surge entre as organizações ambientais um amplo movimento de institucionalização que modifica a forma anterior de voluntariado para o profissionalismo.

Por conta desse processo, em 1987, organiza-se o bloco parlamentar verde que, durante as deliberações do Congresso Constituinte, desempenhou um papel de articulador dos diferentes setores do movimento ambiental, a fim de atuarem como força de apoio no processo de elaboração de uma Constituição que abarcasse as questões relativas ao meio ambiente.

Em janeiro de 1989, no auge das críticas nacionais e internacionais à gestão ambiental brasileira, principalmente como resultado das queimadas na Amazônia e pelo assassinato de Chico Mendes, o governo cria o Instituto Brasileiro de Meio Ambiente e Recursos Naturais Renováveis (IBAMA), fundido a SEMA junto com os órgãos de florestas, pesca e borracha. Na perspectiva de LEIS (1999), a criação do IBAMA implica uma reforma de conceito e de organização na definição da proteção ambiental, já que pela primeira vez se associa com o uso conservacionista de alguns recursos naturais.

O ano de 1990 constitui-se em uma variação na definição da questão ambiental no Brasil, que é precipitada pela decisão do governo brasileiro, respaldado pela ONU, de sediar a Conferência das Nações Unidas sobre o Meio Ambiente e Desenvolvimento, a Rio92. O processo preparatório da Rio-92 começa a afetar, de modo cada vez mais intenso, ainda que diferenciado, os setores que compõem o movimento ambiental brasileiro. Os parâmetros do debate ambiental mudam a partir dessa década, quando já não se fala mais em proteção ambiental de forma isolada, mas de como atingir um novo estilo de desenvolvimento que a atenda de forma apropriada.

Na perspectiva de VIOLA (1995), após a Rio-92, ocorreu tanto um grande passo no plano simbólico e de conscientização, quanto um fracasso no plano político-econômico, 
refletido na incapacidade de se construírem marcos de referências, mecanismos de implementação e instituições correspondentes a essa nova consciência e legitimidade.

Considerando a análise de E. J. Viola e H. Leis, salientamos que as políticas públicas brasileiras estão hoje a meio caminho entre um discurso e uma legislação preocupada com os temas ambientais e um comportamento individual e social bastante predatório. Se, por um lado, as políticas públicas têm contribuído para estabelecer um sistema de proteção ambiental no país, por outro, o poder público é incapaz de fazer cumprir, tanto pelos indivíduos quanto pelas empresas, uma proporção importante da legislação ambiental.

No contexto nacional, deve-se levar em consideração a diferença entre os discursos, os comportamentos individuais e institucionais e as políticas públicas. É fato que o Brasil possui uma legislação comparativamente avançada, contudo, ainda enfrenta sérias dificuldades de ser amplamente praticada tanto pelo poder público quanto pela sociedade civil, onde os comportamentos governamentais e individuais estão muito abaixo da consciência ambiental presente nessa legislação. Uma minoria conscientemente observa em seu dia a dia os critérios de eficiência energética; redução do consumo; redução, reutilização e reciclagem de materiais; participação voluntária em tarefas comunitárias de limpeza ambiental e em grupos de discussão e gestão das questões ambientais.

\subsection{Considerações sobre a questão hídrica}

As atuais preocupações com a realidade dos recursos hídricos, ou seja, com a sua contínua e intensa degradação, tem levantado debates no interior do movimento ambiental, tanto em nível global quanto local, sobre as atividades públicas e privadas voltadas para os diversos usos das águas doces, particularmente, daquelas que atingem diretamente a qualidade de vida da população.

A crescente urbanização e os impactos negativos decorrentes dela repercutem diretamente no funcionamento do ciclo hidrológico, interferindo no rearranjo dos armazenamentos e na trajetória das águas, introduzindo novos meios para a sua transferência na área urbanizada e em torno das cidades. Isso provoca alterações no armazenamento hídrico das áreas circunvizinhas e ocasiona possíveis efeitos adversos e imprevistos também no que diz respeito ao uso do solo. Concomitantemente, esse quadro 
leva à escassez de água doce de boa qualidade, disponível para os diversos usos, como consumo humano, recreação, agricultura, indústria, dentre outros. Existe, portanto, uma relação direta entre a quantidade e qualidade da água doce disponível.

Outrossim, não há como falar de escassez sem fazer referência ao "stress hídrico". Essa terminologia foi estabelecida após os trabalhos da hidrologista sueca Malin Falkenmark, denominado de "water stress index”, baseado num nível mínimo aproximado de necessidade de água "per capita”. Através desse trabalho, chegou-se ao número de 100 litros de água por pessoa/dia como sendo um valor mínimo requerido para as necessidades básicas. Enquanto que, para satisfazer as necessidades dos setores industriais, agrícolas e de produção de energia, esse número é aumentado de 5 a 20 vezes. Numa escala mais alargada, considerou-se que: (a) regiões que dispõem de mais de 1.700 metros cúbicos de água doce renovável por pessoa/ano poderão enfrentar problemas de falta d'água somente em alguns períodos do ano; (b) nas regiões que dispõem entre 1.000 a 1.700 metros cúbicos de água potável por pessoa/ano, é inevitável o quadro de stress hídrico, com tendência a uma situação crônica; (c) regiões que dispõem de menos de 1.000 metros cúbicos de água doce renovável por pessoa/ano já se encontram em situação de escassez.

Se o cálculo do stress hídrico é feito sempre levando em consideração a dimensão populacional de um país e sua oferta de água doce, entendemos que a situação de escassez tende a aumentar em vista do atual crescimento populacional. Conseqüentemente, há mais pessoas para a mesma quantidade de água, situação que pode levar a graves conflitos. Vivemos pois, um quadro de stress hídrico formado, principalmente, pelo tripé: mau uso e conservação da água; urbanização crescente e aumento da população.

A crescente degradação dos mananciais, o desmatamento, o assoreamento dos rios, o uso inadequado de irrigação e a impermeabilização do solo, entre tantas outras ações advindas do modelo deletério de ocupação do espaço urbano, são responsáveis pelos impactos negativos sofridos pelos cursos d'água. Segundo MACHADO (2003), atualmente, mais de 1,3 bilhão de pessoas no mundo carecem de água doce e o consumo humano de água duplica, aproximadamente, a cada 25 anos. Nesse contexto, esse recurso adquire uma escassez progressiva e um valor cada vez maior, tornando-se um bem econômico propriamente dito, o que pode levar, como já dissemos, a conflitos por seu uso. 
Essa perspectiva se justifica, pois análises indicam que apenas uma pequena percentagem de toda a água do planeta é potável ${ }^{2}$ e sua distribuição é assimétrica. Algumas regiões têm muita água potável e pouca população, como a América do Sul com 5\% da população mundial e $26 \%$ da água de escoamento. Outras têm um alto índice demográfico e pouca água, como a Ásia com $60 \%$ da população mundial, mas apenas $36 \%$ da água de escoamento.

Assim, à medida que aumenta a população mundial, chega-se ao limite da capacidade de renovação desse recurso. Por isso, se faz esse prognóstico de que, dentro de uma década, a água doce pode exceder o petróleo como bem precioso e escasso, passando a ser o centro de conflitos e operações de paz.

O Brasil detém $12 \%$ do total de $0,0007 \%$ de toda água doce disponível no planeta destinada ao consumo humano, irrigação e atividades industriais, mas não a tem eqüitativamente distribuída entre a população e, ainda, sofre com o desperdício que perpassa por todos os segmentos da sociedade. Setenta por cento da água brasileira estão na região norte (onde a região amazônica possui $40 \%$ dessa reserva), com apenas $7 \%$ da população; a região nordeste que tem $28,91 \%$ da população dispõe de apenas 3,3\%; a região sudeste que tem a maior concentração populacional dispõe de apenas $6 \%$ dos recursos hídricos. Portanto, apenas 30\% dos recursos hídricos brasileiros estão disponíveis para $93 \%$ da população (MACHADO, 2003).

Observamos também a perspectiva de C. J. S. Machado de que, em média, entre $40 \%$ e $60 \%$ da água tratada são perdidos no percurso entre a captação e os domicílios, em função de tubulações antigas, vazamentos, desvios clandestinos e tecnologias obsoletas. Além disso, a água doce no Brasil está também ameaçada pelo crescimento da população e da ocupação desordenada do solo, do desenvolvimento industrial e tecnológico - poluição por esgoto doméstico, industrial e por agrotóxicos, de processos de erosão, de queimadas, de desertificação e de contaminação do lençol freático.

Além disso, estudos sobre a quantidade e qualidade de água, advertem de que, nos últimos 40 anos com o crescimento da população, de indústrias e de projetos de irrigação na agricultura, o país teve reduzido em $50 \%$ sua disponibilidade de água por habitante.

$297,5 \%$ da água existente no planeta é salgada, $2,5 \%$ doce, sendo que destes $2,5 \%$ somente $0,3 \%$ podem ser encontradas nos rios e lagos. Dados fornecidos pelo Sustaining Water no endereço http://www.cnie.org/pop/pai/image10.html. 
Destaca-se, porém, que esse dado corresponde à média, assim, inúmeras regiões brasileiras já se encontram em situações extremas de escassez e outras em situações mais confortáveis.

$\mathrm{Na}$ perspectiva de SENRA (2001), esse quadro agrava-se ainda mais, pois, atualmente, 11 milhões de pessoas vivem nas cidades e não têm acesso ao abastecimento de água tratada, estando sujeitas a inúmeras doenças de veiculação hídrica. O desperdício está na ordem de $45 \%$ do volume produzido, a coleta de esgotos ocorre para apenas $49 \%$ por meio de rede pública e apenas $15 \%$ recebem algum tipo de tratamento, contribuindo para o aumento da insalubridade nas áreas urbanas.

Esse processo tende a aumentar gradativamente, fruto da ausência de políticas públicas de fixação do homem no campo. Isso reverte no inchaço das cidades o que, aliado a falta de planejamento, resulta, entre outras coisas, na qualidade e quantidade de água para consumo; na impermeabilização do solo, que aumenta e interfere no curso das águas, as quais arrastam os resíduos, provocando erosões e inundações decorrentes das chuvas intensas.

Assim, consideramos a afirmação de SENRA (2001) de que todo recurso investido em saneamento e em obras hídricas - com a oferta de água de qualidade; a coleta e tratamento de esgotos; a coleta regular de lixo e água pluviais -, trarão melhoria da qualidade de vida às comunidades e uma economia substancial nos gastos do sistema de saúde pública, com redução de instalações, atendimentos, internações, remédios etc.

Esse quadro é resultado de que, no Brasil, a questão do saneamento e gestão das águas se encontram historicamente interligadas, particularmente, em razão da grande maioria dos municípios não tratar seus esgotos, sendo comum o seu lançamento direto nos cursos d'água. Assentimos com a análise de C. J. S. Machado e R. T. Neder (2002) de que esse fato é resultado da concepção sanitária do país, baseada na prioridade histórica dada ao abastecimento de água para a população como pré-condição para a melhoria de suas condições sanitárias. Por mais de 60 anos, essa política foi fortemente dominada pela supremacia da geração de energia, justificada pelo modelo de desenvolvimento imposto ao país. Essa orientação começou a apresentar, desde o final da década de 1990, uma persistente crise, exemplificada pelas falhas no abastecimento em mananciais, poluição dos reservatórios naturais e artificiais. Até a década de 1990, ainda não se havia efetivado a associação entre o saneamento e a questão ambiental, embora estivesse presente no 
discurso das peças legislativas e em inúmeros documentos, artigos e declarações de organizações e movimentos ambientais.

Atualmente, parte dos profissionais e técnicos atuantes nesse setor entende a importância do saneamento ambiental. Assim como, outros sujeitos relevantes têm assumido esse discurso, exemplificados pelo setor privado de engenharia, consultoria e gerenciamento de obras públicas e pelos fabricantes de equipamentos industriais, ampliando o conceito de saneamento ambiental que envolve, além do abastecimento de água e tratamento de esgotos, drenagem e resíduos sólidos e controle de vetores (MACHADO, 2003; NEDER, 2002).

Além da perspectiva de mudança nesses setores profissionais, salientamos a existência de uma certa mobilização e participação de parcela da sociedade civil no processo de gestão participativa dos recursos hídricos em muitas regiões como, por exemplo, através dos Comitês de Bacia Hidrográfica, em Conselhos Gestores e em Fóruns Públicos.

\subsection{Considerações sobre a gestão ambiental no Brasil}

A partir da segunda metade da década de 1970, segmentos da sociedade civil brasileira, como os movimentos sociais e ONG's, deram início ao debate e a crítica às políticas oriundas do modelo de desenvolvimento abraçado pelo Estado brasileiro. Autores como H. Acselrad e R. T. Neder levantam o debate sobre a questão da gestão de políticas públicas ambientais no Brasil e esse contexto sociopolítico levou uma parcela dos representantes do Estado a inserirem a questão ambiental na agenda estatal.

Do ponto de vista de NEDER (2002), esse momento sociopolítico se traduziria em uma diversidade de formas de ação dos movimentos de cidadãos, proporcionando a discussão, tanto na sociedade civil quanto em alguns setores do Estado, na tentativa de inserir, nas prioridades dessa agenda desenvolvimentista, uma sub-agenda que abarcasse ações em áreas tão diversas como: saneamento básico e ambiental; conservacionismo clássico de parques e reservas; recursos hídricos em regiões metropolitanas e a necessidade urgente de ação do poder municipal sobre habitação, uso e ocupação do solo urbano e rural. 
Outrossim, chamamos a atenção para o fato de que com os novos dispositivos permitidos pela Constituição Federal de 1988, o centralismo político do Estado em geral, inclusive no que se refere à gestão de recursos naturais, começa a dissolver-se. Esses dispositivos passam a atribuir aos recursos naturais a condição não apenas de bens da União, passíveis de serem convertidos em bens de mercado, mas também patrimônio e valor da comunidade.

Entretanto, também atentamos para a discussão levantada por NEDER (2002) na insistência de que a manutenção do paradigma de uma cultura política autoritária e coronelista é um dos aspectos mais prejudiciais que o país ainda vive, mesmo após 1988. Essa característica leva à incapacidade da sociedade em gerir seu próprio futuro, o que se traduz por esferas públicas empobrecidas ou limitadas. Ou seja, observamos que a sociedade civil não consegue regular ou rebater as condições sociais e ambientais deletérias impostas pelo modelo nacional de desenvolvimento. Além disso, na maioria das vezes, controlar esses efeitos agressivos do desenvolvimento e gerir políticas municipais de saneamento básico, habitação, saúde, são para prefeitos, industriais, vereadores e comunidades dois processos independentes.

Sobre a elaboração e gestão de políticas públicas ambientais pelo Estado, em seus três níveis; acordamos com ACSELRAD (2001) sobre a agravante de que os órgãos ambientais foram se caracterizando por uma acentuada descontinuidade administrativa. Ou seja, houve fusões e desintegrações organizacionais, mudanças súbitas na relação de hierarquia a várias instâncias ministeriais e a um ainda maior número de respectivos responsáveis políticos. Assim, frente à delimitação burocrática da área de competência do setor ambiental do governo, a política de meio ambiente foi contribuindo para uma espécie de funcionalização do espaço territorial segundo três modalidades: (1) regiões dotadas de vocações naturais para inserção no mercado nacional e global; (2) áreas ricas em recursos genéticos, consideradas natureza a ser preservada, como ilhas de conservação ou a serem exploradas de modo que se pretende sustentável; (3) áreas residuais economicamente deprimidas e submetidas a processos erosivos e degradantes, desprovidas de interesse estratégico para o capital. Portanto, com tal redução da dimensão ambiental das políticas públicas, deixa de se considerar o caráter integrado entre os processos sociais territorializados, a dinâmica reprodutiva dos ecossistemas e a construção dos direitos ambientais da população. Logo, 
após mais de 30 anos de política ambiental, o que parece caracterizar a ação governamental brasileira é ainda o total isolamento entre o setor ambiental do governo e os mecanismos da efetiva gestão estatal do meio ambiente. Na verdade, a fragmentação e a pulverização das instâncias de decisão da política ambiental exprimem o fato de que a questão ambiental não é ainda uma questão de Estado no Brasil.

Por conta dessa forma do Estado lidar com as questões ambientais que cada vez mais afetam a qualidade de vida dos cidadãos, é que estas têm se estendido a alguns dos segmentos da sociedade civil, onde esses sujeitos sociais organizados pretendem discutir e buscar soluções mais concretas. Essa mobilização tem possibilitado a negociação com o Estado, nos seus três níveis, para a discussão e implementação de políticas públicas ambientais. A questão aqui é se esse processo restrito a uns poucos segmentos da sociedade civil tem a possibilidade de alcançar uma parcela cada vez maior dessa sociedade, em que a participação democrática e a socialização da política seriam condições do desenvolvimento, que contaria, pois, com a participação da sociedade civil nos fóruns de discussão sobre as decisões de interesse público.

Contudo, por si só, a conscientização da sociedade civil sobre a premência das discussões e busca de soluções para as questões socioambientais e da importância do diálogo junto ao Estado não é suficiente. Salientamos, também, a importância dos recém instituídos espaços públicos, como a alavanca para que esse processo ocorra. Todavia, nos questionamos se esses espaços estão efetivamente funcionando, tanto no seu desenho institucional que pode permitir, ou não, a equidade de participação de todos os segmentos da sociedade civil quanto nas práticas que esses participantes efetivamente proporcionam, principalmente, quando nos referimos à questão ambiental. 


\subsection{Considerações sobre a questão urbana e a participação política da sociedade civil brasileira}

A organização e o desenvolvimento urbano são essenciais ao incremento socioeconômico e cultural da sociedade. Contudo, a forma como isso vem ocorrendo tem gerado graves danos ambientais, limitando suas atividades socioeconômicas e culturais. Derivado do processo de crescimento urbano intenso e carente de um planejamento prévio, esse impacto negativo gera alterações na paisagem e perda das funções ecológicas dos sistemas ambientais, interferindo nas atividades e funções dessa sociedade. Logo, tem sido responsabilizado pelos impactos negativos diretos ao meio ambiente o modelo de desenvolvimento adotado pelo Brasil e a urbanização crescente e sem planejamento, conseqüência deste. Tais impactos se desdobrariam, principalmente, na poluição hídrica e atmosférica; na retirada da cobertura vegetal e na descaracterização dos cursos d'água; nos processos erosivos; na intensiva e extensiva impermeabilização do solo; na constância das enchentes etc.

Dados da primeira metade da década de 1990 revelaram que 75\% da população brasileira vivem em áreas urbanas, periurbanas e semi-urbanizadas. A população urbana cresceu em média $3 \%$ contra um decréscimo de $0,6 \%$ da população rural, em relação à década de 1980. Logo, caminha-se para um quadro que tende à marca de $80 \%$ da população nas cidades, no início do século XXI. Autores como A. Christofoletti; B. Braga; C. L. Menezes; C. J. S. Machado; H. Ascerald; H. Rattner; M. G. L. Silva; N. Felicidade Valencio; R. T. Neder levantam o debate sobre a degradação ambiental e os graves problemas sociais, reflexos da rápida e crescente urbanização sofrida pelo Brasil nos últimos quarenta anos. Expressam a preocupação de que o contexto atual torna necessária a urgente implantação de medidas que permitam o controle sobre a amplitude da deterioração ambiental advinda desse processo.

Frente a esse debate, observamos que as cidades emergem como sendo organismos permanentes de ação cumulativa, proporcionando, em escalas cada vez maiores, o aumento da população e da área ocupada. Esse fato, além da possibilidade de provocar diretamente a degradação do meio biofísico, gera o movimento de numerosa população de diferentes regiões para os centros urbanos em busca de novas oportunidades. 
As alterações negativas no meio ambiente, proporcionadas pelo quadro exposto, têm reflexo imediato na paisagem local devido às alterações nos fluxos de energia e no próprio meio ambiente.

Se a urbanização diretamente cria ambientes que são avaliados como positivos à saúde e ao bem-estar das pessoas, ao mesmo tempo geram efeitos que podem promover a desestabilização do ecossistema. Muitos impactos indiretos encontram-se associados à urbanização, normalmente imprevistos e não planejados, ocasionando conseqüências positivas ou negativas, tanto a curto como em longo prazo (CHRISTOFOLETTI, 1993:41).

Nas palavras de SILVA (1994), os processos de urbanização do final do século XX confrontam-se diretamente com o meio ambiente dito natural, em função do dilema estabelecido pela sociedade entre preservação versus ocupação.

Por conta de todo esse processo agressivo H. Ascerald; H. Rattner; N. Felicidade Valencio; e R. T. Neder atualmente discutem a cidade, vinculando-a a todo o contexto em que se insere, não apenas na degradação do espaço urbano, mas de todos os espaços para além do urbano, incluindo-se a totalidade da cobertura vegetal e dos cursos d'água. Consideramos que essa ocupação deletéria exemplifica-se quando se confronta a substituição da cobertura vegetal por casas e ruas, com um proporcional adensamento populacional. Juntamente com o aspecto visual externo, implanta-se ainda uma rede de comunicações e novos fluxos para o abastecimento das necessidades, interligam-se também mudanças relacionadas com a agricultura e com o comércio regional.

Dentro dessa abordagem global das questões urbanas, acordamos com esse debate destacando a acelerada metropolização e a conseqüente degradação da qualidade de vida urbana geradas por outras duas ordens diferentes: a pobreza existente nas cidades, que afeta a grande maioria da população brasileira e os problemas ambientais decorrentes da concentração de atividades econômicas nessas áreas. Assim, o processo de inchaço das cidades aumenta consideravelmente o número de moradores na condição de desassistidos de uma cidade ambientalmente adequada. Logo, é de suma importância a abrangência dos serviços públicos de infra-estrutura como abastecimento de água potável, saneamento e melhoria das condições ambientais.

Observamos a afirmação de RATTNER (2001) sobre o modelo "obsoleto $e$ irracional" de ocupação do espaço urbano. "A urbanização rápida e a intensa 
concentração de indústrias, serviços e, portanto, de seres humanos, têm transformado as cidades no oposto de sua razão (...)” (RATTNER, 2001:09), ou seja, um espaço em que se almeja alcançar equidade socioambiental, política e cultural. Acrescentamos ainda a agravante no caso do Brasil, ressaltado por VALENCIO (et. al., 2004:01) de que:

\begin{abstract}
a produção social contemporânea das cidades esteve hegemonicamente circunscrita a uma mentalidade modernizante, em relação a expressão material de crescimento e conservadora, no que concerne às práticas balizadoras desse crescimento.
\end{abstract}

Logo, torna-se cada vez mais urgente a discussão e a busca de soluções imediatas e duradouras, a fim de minimizar e/ou resolver as consequiências socioambientais advindas desse modelo deletério de ocupação do espaço urbano. Frente a esse contexto, entendemos como cada vez mais necessária a participação da sociedade civil nas decisões acerca da ocupação e utilização dos espaços públicos, principalmente, quando essa ocupação afeta a qualidade socioambiental dessa comunidade. Os cidadãos têm direitos sociais inerentes à infra-estrutura básica, como: expansão dos serviços de água, luz, saneamento, coleta de lixo, postos de saúde, habitação. Por conseguinte, com esses direitos sendo atendidos, aumenta a probabilidade de que a cidadania, em seu sentido amplo, venha a ser conquistada.

Segundo o debate levantado por B. Braga; C. J. S. Machado; H. Rattner; M. G. L. Silva, atualmente a abrangência do direito à infra-estrutura básica não está sendo atendida pelos três níveis do Estado - federal, estadual e municipal. Essa estagnação, quando se estende aos municípios, gera situações de inoperância e ausência de políticas públicas, tanto no meio urbano quanto no campo. Estes são direitos socioambientais para os quais não basta a legislação vigente e/ou a instituição de políticas públicas e a sua devida implantação, a consolidação desses direitos depende de condições outras. Condições outras que poderiam ser viabilizadas através dos movimentos sociais; da mobilização por meio do terceiro setor; da participação direta sobre o controle do Estado e das instituições; das deliberações da esfera pública não estatal, onde os temas próprios da esfera pública são decididos por via do processo de formação de consenso.

Levando em consideração esse ponto de vista, entendemos como essencial o envolvimento da sociedade civil nas decisões referentes às questões socioambientais, tanto por razões de ordem democrática quanto por acreditarmos que, sem essa participação, as 
decisões tomadas de forma tecnocrática e autoritária tenderão ao fracasso. Essa participação acabaria por justificar estruturas que favoreçam o desenvolvimento do diálogo e da negociação, ou seja, a realização de pactos em busca de um ambiente equânime e uma conseqüente melhora na qualidade de vida de todos os segmentos da sociedade civil. RATTNER (2001) acrescenta ainda que esse é o desafio que ora se apresenta aos planejadores e administradores urbanos de como implementar esse novo conceito de poder político participativo.

A evolução pela qual passou o movimento ambiental, aliado ao processo acelerado e deletério de urbanização, trouxeram a questão ambiental urbana para a agenda de discussão dos modelos de desenvolvimento e da participação para a construção de uma democracia participativa. Assim, a mudança na resolução dos problemas socioambientais passa necessariamente por um espaço público de debate e deliberação, sendo imprescindível o exercício da cidadania participativa no processo de tomada de decisão sobre as questões relativas ao uso do espaço urbano.

A questão ambiental urbana gera conflitos, envolvendo relações de poder, características de como ocorreu e ocorre a apropriação e uso do meio ambiente, no qual estão envolvidas articulações entre sujeitos distintos, com seus interesses, desafios, contradições, problemas e possibilidades (BRAGA, 1997). Observamos que esse conflito fica claro quando a sociedade estabelece uma relação lógica imediata entre a degradação ambiental e a ação de agentes sociais determinados. A resolução desse conflito perpassa pela responsabilidade do Estado e co-responsabilidade da sociedade civil, ou seja, a participação, a reivindicação, o controle, enfim, o exercício da condição do cidadão. Na perspectiva de RATTNER (2001), consideramos que o planejamento de ocupação do espaço urbano pode ser transformado em instrumento de democratização, ao contrário do que tem sido feito - um processo decisório tecnocrático e autoritário.

Ponderamos que o contexto sociopolítico atual, onde a sociedade civil dá sinais de estar mais participativa, como através dos NMS, pode ser visto como o crescimento de um espaço público autônomo, capaz de recolocar no debate valores e interesses universais e locais. As práticas do movimento ambiental se orientam para a importância da utilização intensa desse espaço público. Assim, parece razoável acreditar que o futuro do movimento ambiental está em parte atrelado às possibilidades que derivem do espaço público e da 
existência de uma sociedade civil fortemente estruturada e participativa. Logo, fora desse espaço público consolidado, que é capaz de permitir o encontro e o diálogo entre os mais diversos segmentos da sociedade, o movimento ambiental poderá encontrar sérios obstáculos ao seu desenvolvimento político.

Na questão da participação da sociedade civil em espaços públicos de discussão, especialmente na gestão de recursos hídricos, são referidos como exemplos os Comitês de Bacia Hidrográfica. Estes se estabelecem como uma das ferramentas, possibilitada pela Política Nacional de Recursos Hídricos que, mesmo que nem sempre satisfatoriamente, propicia à sociedade civil organizada participar no processo de gestão das Bacias Hidrográficas a nível regional.

Nas considerações de MACHADO (2003), esse espaço facilita a transparência e a permeabilidade nas relações entre empresários, sujeitos sociais e ONG's, a interconexão entre sujeitos reguladores e regulados e também incorpora os interessados, constituindo-se como um canal formal de participação de cidadania. É um fórum de articulação, de negociação e de discussão, portanto, previne e reduz riscos de que o aparato público seja apropriado por interesses imediatistas, orientando as políticas públicas e formulando planos de desenvolvimento integrado.

No entanto, esse espaço discute metas, intervenções e negociações de ocupação e desenvolvimento de um bem público como são os recursos hídricos, que açambarca interesses diversos como políticos, sociais, econômicos e culturais, podendo gerar entraves e dificuldades de participação de todos os segmentos da sociedade civil, usuários desse recurso. Existe garantia legal para a participação da sociedade civil, em escala regional, nos referidos Comitês, entretanto, isto tem ocorrido de forma pontual e restrita. Como sustenta MIRANDA (2001), ainda que essa garantia legal exista e seja um avanço, não existe a efetivação do caráter participativo do cidadão comum no planejamento e na elaboração de propostas institucionais na área de políticas ambientais.

Consideramos também a observação de MACHADO (2003) de que esse espaço possibilita o diálogo de diferentes segmentos da sociedade civil e, por isso, envolve negociações e acordos de diferentes interesses. Entretanto, é importante registrarmos o fato de que alguns desses segmentos possuem recursos econômicos, conhecimentos e habilidades técnicas e científicas que outros não têm e que, através de manobras, oratória 
etc. podem conduzir importantes tomadas de decisões.

Já na escala local, estabelecem-se outras ferramentas como os Conselhos Gestores e o Orçamento Participativo (OP) que podem efetivar a participação da sociedade civil no processo de gestão ambiental. O OP pode se tornar eficaz na tomada de decisões sobre o emprego de verbas públicas, a fim de buscar soluções dos problemas enfrentados pelos diversos setores e segmentos da cidade.

Uma corrente de autores como B. S. Santos; L. Avritzer; L. Moll; J. Moll; N. B. Fischer; T. Genro destaca o OP como um importante espaço de participação popular, onde torna-se possível o exercício do papel de cidadão ativo. Citam como exemplo o município de Porto Alegre, com experiência de mais de dez anos, mas temos outras experiências de outros municípios no próprio estado do Rio Grande do Sul, no estado de Minas Gerais e no estado de São Paulo. Ponderamos se através da participação nesse espaço, o citadino poderá exercer o direito de planejar as ações direcionadas para a ocupação e desenvolvimento do espaço urbano e indicar o encaminhamento dos gastos municipais em infra-estrutura.

Corroboramos com a perspectiva de MACHADO (2003) sobre a importância da participação da sociedade civil no planejamento e gestão da ocupação e crescimento urbano, pois esta não envolve apenas um princípio democrático de sentido humanista e filosófico, mas é também parte importante na construção de uma nova forma de encarar a gestão de recursos públicos caros e escassos. Esse envolvimento pressupõe ainda o fato de que uma pessoa participante da tomada de uma decisão se sentirá comprometida e procurará vê-la cumprida. Será, portanto, um agente na implementação dessas decisões, não apenas um agente passivo, pois a aceitação é maior quando existe participação em todo o processo de gestão de um projeto ou de uma política e quando o participante faz sua própria escolha.

Em nossa perspectiva, esse espaço público local de discussão e deliberação pode vir a ser o OP, local onde se encontram os diversos segmentos que compõem a sociedade civil, espaço heterogêneo, complexo em seus diversos interesses e compreensões das questões socioambientais. É território por onde perpassam importantes questões de infra-estrutura urbana e onde são tomadas as decisões sobre suas resoluções e futuras intervenções no ambiente urbano, especialmente no que se refere aos recursos hídricos. Autores como B. S. Santos; E. Dagnino; H. Rattner; L. Avritzer; L. Moll; J. Moll, entre outros, também 
levantam o debate de que nesse espaço se poderá ver efetivado o exercício da cidadania ativa, sob o teto da discussão, do encontro e do diálogo dos diversos segmentos da comunidade mediados pela democracia participativa.

Por outro lado, o OP pode também sofrer com os mesmos problemas levantados por MACHADO (2003); MIRANDA (2001) como no caso dos Comitês de Bacias Hidrográficas, gerados, particularmente, por deficiências no desenho institucional que pode não permitir o acesso a esse espaço e/ou o poder de deliberação de todos os segmentos da sociedade civil. Ou seja, a não efetivação da participação do total desses segmentos para o planejamento e elaboração de políticas públicas socioambientais, impede assim o exercício do cidadão em buscar um ambiente urbano equânime, mesmo com a abertura de espaços públicos para tal.

Assim, é no esforço de analisar a possibilidade de que essa perspectiva realmente se configure em um espaço onde a discussão das questões ambientais, particularmente, sobre a gestão dos recursos hídricos se torne eficaz que traremos à luz da discussão os debates levantados até aqui, confrontados com a experiência do OP na cidade de São Carlos, SP. 


\section{Capítulo 3 - O Orçamento Participativo (OP) no Município de São Carlos}

\subsection{Gênese sociopolítica do Orçamento Participativo}

Por conta das transformações sociais, políticas e culturais pelas quais passa a sociedade brasileira desde os anos de 1990, propiciadas pelo avanço da democratização e da diferenciação social aliado à valorização da democracia participativa, começa a se consolidar, tanto no campo político quanto no social, a importância da participação da sociedade civil na gestão da coisa pública. Destacados autores como B. S. Santos; B. Wampler; E. Dagnino; L. Avritzer; M. A. Nogueira; Z. Navarro que levantam o debate sobre a participação política da sociedade civil e a relevância desta ser incorporada ativamente aos processos de governo e de implementação de políticas públicas, que irão ao encontro da implantação do Orçamento Participativo (OP) em alguns municípios brasileiros.

A institucionalização do OP e de outras experiências participativas sinalizam na direção da reorientação dos objetivos dos governos locais para que venham a atender os interesses de todos os segmentos da sociedade civil. Para esses autores, é possível supor que o progressivo desmoronamento da estrutura administrativa erigida a fim de garantir privilégios e favorecimentos, caminha para a construção de um novo modelo de gestão. A institucionalização desse espaço apontaria para a ruptura com o uso privado dos recursos públicos; a radicalização do sentido democrático das funções dos governos locais; a criação 
de novos espaços públicos de negociação; a descentralização do poder; a redefiniç̧ão das relações governo e sociedade civil, elementos esses essenciais para que todos os cidadãos possam desenvolver sua capacidade de saber escolher, exercer sua escolha e se beneficiar dela.

No dizer de WAMPLER (2003), o OP não pode ser entendido como somente um processo de participação, de elaboração de demandas ou de deliberação dos cidadãos. Esse espaço é uma instituição inovadora e empolgante porque tem o potencial de afetar os cidadãos, a administração e a política de diversas formas, iniciando uma transformação social mais ampla. É uma instituição democrática com que possibilita a resolução de disputas, coloca grupos divergentes juntos e permite o debate público. E, ainda, alia democracia direta com democracia representativa.

Considerando essa perspectiva, entendemos a necessidade de levantar o debate acerca dos resultados da implantação desse espaço. A participação em espaços deliberativos como o OP, onde são discutidas as ações e decisões governamentais e onde são colocadas em pauta principalmente as questões de infra-estrutura e planejamento urbano, pode levar a uma maior concentração na obtenção de vantagens e de resultados, do que da forma como se dá a relação política e social entre o Estado e a sociedade civil no país. Em contrapartida, observamos também que esse espaço pode ser uma oportunidade dessa sociedade se habituar com esse tipo de exercício político, transformando-o em uma brecha que pode dar conta mesmo como um processo de educação para a democracia participativa.

Acordamos teoricamente com AVRITZER (2003) que entende o OP como uma forma de re-balancear a articulação entre a democracia representativa e a democracia participativa. Essa característica do OP em poder combinar democracia participativa com democracia representativa é uma das mais marcantes. Os cidadãos participam diretamente dos processos de tomada de decisão, através das assembléias regionais, mas, também delegam autoridade aos seus representantes eleitos (conselheiros e delegados) para atuarem na fase deliberativa.

Assim, da definição teórica do OP destacamos quatro características que encerram a essência desse espaço público. Umas das principais é a eleição dos conselheiros pelos participantes e empossados pelo processo representativo. Esses representantes têm o poder deliberativo em assembléias regionais e temáticas que funcionam dentre critérios de 
universalidade participativa. Logo, teoricamente, todos os segmentos da sociedade civil tornam-se membros desse processo com igual poder de deliberação. Outra característica é a re-introdução de elementos de participação local, tais como os conselhos em nível municipal, representando uma combinação dos métodos da tradição de democracia participativa. A terceira é o princípio da auto-regulação soberana, isto é, a participação envolve um conjunto de regras que são definidas pelos próprios participantes, vinculando esse espaço a uma tradição de reconstituição de uma gramática social participativa, na qual as regras de deliberação são determinadas pelos próprios participantes. Por último, a tentativa de reversão das prioridades de distribuição de recursos públicos em nível local, através de uma fórmula técnica, que varia de município para município, de determinação de prioridades orçamentárias que devem privilegiar os setores mais desassistidos da população.

Dentro dessa perspectiva teórica, B. S. Santos; B. Wampler; L. Avritzer; M. A. Nogueira; Z. Navarro entendem que o OP pode tornar-se uma esperança de justiça distributiva, uma possibilidade de reforma do processo de tomada de decisão local e um processo de incentivo e educação para a cidadania ativa, incorporando todos os segmentos da sociedade civil; assim como, contribuir para as recentes discussões sobre os limites da democracia representativa; sobre a possibilidade de se propor um modelo alternativo de democracia ou sobre a articulação entre os dois principais modelos disponíveis democracia representativa e democracia participativa.

A partir dessa perspectiva, podemos levantar a questão da democratização da gestão municipal, onde a forma de governar necessita de mudanças. Isto é, necessita ganhar transparência, controle social, descentralização e incorporação da participação política, a fim de superar as estruturas que apóiam o domínio das elites locais. Assim, a descentralização do governo local e a institucionalização de espaços públicos de gestão e participação política são um projeto de socialização do poder, de inclusão social e de aumento da eficácia na oferta de serviços públicos. Ou seja, atuar para garantir um processo de mudanças sociais orientadas para atender as múltiplas dinâmicas da sociedade na defesa e ampliação da cidadania e da qualidade de vida.

Observamos que a participação política tornou-se citação obrigatória para a renovação dos discursos a respeito da democracia, do Estado e da gestão pública. A gestão 
participativa é associada a um Estado mais aberto à heterogeneidade do tecido social, mais democrático e mais competente. As discussões teóricas existentes sobre o OP levam a um debate em torno deste e dos novos modelos de democracia. Diversas análises sobre a democracia, assim como diversos modelos para o entendimento desse espaço, emergiram desse embate. SANTOS (2002) denomina o OP como uma concepção distributiva da democracia e o caracteriza a partir de três elementos, - espaço onde todos os segmentos da sociedade civil têm o direito à participação, sendo que as associações já instituídas não detêm prerrogativas especiais; onde a participação é dirigida por uma combinação de regras de democracia direta e democracia representativa; onde os recursos de investimento são distribuídos de acordo com um método objetivo baseado na combinação de critérios gerais e de critérios técnicos. Para NAVARRO (2003), o OP é uma concepção afirmativa de democracia e se caracteriza como uma prática que permite aos segmentos sociais marginalizados adquirirem as mesmas capacidades e direitos que aqueles localizados no topo da estrutura social.

Por conta das discussões teóricas dessas características e de recentes pesquisas, o debate atual sobre o aprofundamento da democracia está levando em consideração o OP, pois se entende que esse espaço público tem em seu bojo alguns pontos relevantes que não podem ser ignorados. Análises de algumas experiências participativas (SANTOS, 2002; FEDOZZI, 2000; MOLL \& FISCHER, 2000) dão conta de que, o OP pode levar a um aumento da participação da sociedade civil na decisão sobre a distribuição de recursos orçamentários, a um aumento de acesso a recursos públicos e direitos, a um aumento da capacidade de decidir e uma certa capacidade de determinar a regra do processo deliberativo.

Logo, quando se discutem as questões democráticas, por vezes, a experiência do OP é citada como uma forma de democracia deliberativa, pois, no interior desse espaço os cidadãos e/ou seus representantes eleitos podem deliberar sobre as questões e temas públicos, sob condições que levam a uma reflexão racional e argumentativa e assim instituir um processo público de decisão coletiva. Esse processo revela a predisposição de seus participantes em aceitar a vontade coletiva em detrimento de interesses e perspectivas individuais. NAVARRO (2003) entende que essa experiência traduz um processo aberto e potencialmente transformador, pois a idéia geral da democracia deliberativa propõe que sua 
implementação possa gerar novas oportunidades para criar, modificar ou revisar interesses e preferências através do discurso argumentativo, constituinte do mecanismo essencial de sua operacionalização.

Entretanto, para além dessas expectativas, em sua maioria ainda mais teórica que práticas, não podemos deixar de considerar que na institucionalização do OP o seu desenho institucional pode levar à manutenção da estrutura política elitista e de apartação políticosocial de alguns segmentos da sociedade civil, impedindo e/ou dificultando a efetivação dessas definições teóricas. Aliado a esse fato, pela sua falta de experiência, a sociedade civil pode ainda não atuar eficazmente, levando, por vezes, esse espaço ao esvaziamento e/ou apropriação por parte do poder público e/ou de maiorias ou grupos. Assim, os conselhos podem tornar-se espaços de cooptação ou espaços que o poder público não os reconhecem ou não lhes atribuem poderes de decisão.

Outro ponto a ser considerado é que essas experiências não surgem em qualquer lugar e análises generalistas não dão conta das particularidades do processo. Elas seriam fruto da ação de sujeitos políticos concretos, de movimentos sociais e também de conjunturas políticas particulares, em localidades que, ou por dificuldades das próprias elites consolidarem suas lideranças e representações, ou ainda pelo surgimento de oportunidades para novos sujeitos sociais se converterem em sujeitos políticos e elegerem governantes para se buscar uma nova regulação social.

Corroborando com nossa perspectiva, NOGUEIRA (2004) levanta a discussão de que existem três questões que não podem deixar de ser citadas quando se fala em espaços públicos institucionalizados. Por ocasião da implementação, os governos buscam fixar mecanismos participativos voltados para integrar grupos menos poderosos no processo decisório. Entretanto, os mais poderosos ainda têm força para impedir e/ou interferir em tal participação. A questão da desigualdade - espaços são criados para que todos participem, entretanto, desigualdades socioeconômicas e culturais podem criar obstáculos à participação de certos grupos sociais. A questão da cooptação - os espaços de participação podem ser genuinamente representativos, entretanto, o desequilíbrio entre o governo e os participantes, quanto ao controle da informação e dos recursos, pode fazer com que a participação seja manipulada pelos membros do governo. 
Logo, observamos que as experiências de participação política nos governos locais também podem ocultar os seus significados. Essas experiências logram construir novos espaços públicos e novas formas de exercício de cidadania, todavia, podem não levar ao fortalecimento da democracia. Podem ser apropriadas como mecanismos de cooptação e de controle político pelos setores conservadores, prestigiando a imagem dos governantes que as adotam. Assim, acabam por desarticular a capacidade de pressão de importantes setores da sociedade civil. No entanto, entendemos ser temerário afirmar seu fracasso, pois a eficácia de toda e qualquer experiência seria um pensamento ingênuo quando se espera, como num passe de mágica, que aqueles que nunca decidiram passem de imediato a disputar com sucesso, em pé de igualdade, com os representantes governamentais.

Algumas considerações levantadas por análises de experiências participativas (SANTOS, 2002; FEDOZZI, 2000; MOLL \& FISCHER, 2000), afirmam, que, sem dúvida, foi criada uma nova institucionalidade. Porém, em alguns casos, ainda pode não estar funcionando bem, controlado de cima, pelos governos municipais. No entanto, reúne cidadãos que se sentem comprometidos com o interesse público, que vivem e exercitam o aprendizado democrático e apresentam para o conjunto da sociedade uma nova forma de participação.

Corroboramos com o debate de NOGUEIRA (2004), afirmando que apesar da possibilidade da existência de contradições e experiências não tão bem sucedidas, a institucionalização desses espaços inovadores de gestão municipal aponta que o governo e a sociedade civil se aproximam, ampliam e criam novos espaços públicos, mobilizando esforços conjuntos para enfrentar problemas sociais. Dessa forma, percebe-se que estão ocorrendo transformações, tanto no Estado quanto na sociedade civil, na forma como enfrentam as questões de interesse público.

Ao mesmo tempo em que ocorre esse processo de organização e modificação sociopolítica e cultural da sociedade, o território, as cidades também passam por um processo de modificações de toda ordem, ou seja, ambientais, sociais, econômicas e culturais. Sofrem com o processo de inchaço e ocupação desordenada e deletéria do espaço. Observando que o OP é um espaço onde são discutidas as ações e decisões governamentais com relação às questões de infra-estrutura e planejamento urbano, conjeturamos, se, este 
pode ser uma ferramenta para a modificação da ação da sociedade civil com relação às políticas públicas socioambientais.

Levantamos esse debate, pois experiências participativas têm demonstrado (KONISKY \& BIERLE, 2001; BUSENBERG, 2000; MOLL \& FISCHER, 2000; VIEIRA, 2000), que é possível, através desses espaços, implementar políticas de gestão municipal, romper com práticas setorizadas e incorporar a preocupação com a degradação dos recursos naturais.

As ações nessa direção estimulariam o engajamento da sociedade civil em encontrar alternativas conjuntas para fortalecer um compromisso com a cidade, tornando-a, no dizer de H. Acselrad mais durável ${ }^{3}$. Dessa forma, o OP pode vir a ser um instrumento importante de fortalecimento de práticas políticas includentes e orientadas na busca da formulação e implementação de ações públicas sustentáveis no planejamento de cidades com equidade socioambiental.

BUSENBERG (2000), ao analisar a eficácia da participação de cidadãos em conselhos consultivos na gestão de políticas públicas ambientais no estado do Alaska/USA, conclui que certos recursos (fundos financeiros, poder de decisão, assistência técnica e/ou científica etc.), aumentam a habilidade dos cidadãos participantes na implementação segura de mudanças políticas propostas por eles. Logo, a eficácia da participação dos cidadãos aumenta, se eles possuírem recursos necessários para verem implementadas suas propostas, no que é corroborado por KONISKY \& BEIERLE (2001) que chegam à conclusão similar no estudo sobre a região dos Grandes Lagos/USA.

Questionamo-nos se o OP, por ser um espaço público, deliberativo sobre as questões de implantação e manutenção de infra-estrutura e planejamento urbano e dotado de recursos, tanto financeiros quanto técnicos, poderia levar a uma efetiva participação do cidadão nas questões socioambientais e a uma maior eficácia na implantação de suas propostas.

\footnotetext{
${ }^{3}$ Vide ACSELRAD, H. (2001). (op.cit.). O autor entende ser um desafio que novos parâmetros, dito sustentáveis, possam tomar forma concreta nas cidades ora existentes e regidas por outras lógicas. Para ele, as concepções de um urbanismo ecologizado, capazes de economizar espaço e energia, poderiam logo encontrar seus limites ante as práticas cotidianas. Os desafios das propostas estariam menos nas formas materiais que tenciona criar e mais em se embasar nos princípios da democratização dos territórios, no combate à segregação sócio-espacial e na defesa dos direitos de acesso aos serviços urbanos.
} 
Vindo ao encontro de nosso debate, MANTOVANELI (2001); DOWBOR (2000) e GENRO (2000) acreditam que o OP pode ser uma referência em termos de um processo que funda uma nova política e uma nova ética social, aquela em que a política social e política ambiental são conceitos indissociáveis. Sendo o OP como

(...) um 'novo contrato social' da modernidade, para forjar não só um novo tipo de Estado, mas também uma nova reflexão sobre um novo tipo de sociedade, uma prática cotidiana da cidadania que expresse um novo modo de vida (GENRO, 2000:15).

Mas, o OP

não basta, e não substitui a cidadania nacional, ou a cidadania global que está emergindo. Mas uma cidadania consciente e organizada constitui, sem dúvida, o investimento mais sólido, a médio e longo prazo, para conseguirmos transformações políticas mais amplas (DOWBOR, 2000:13).

A literatura levanta o debate de que o OP pode ser uma importante ferramenta na construção de novas relações entre o Estado e a sociedade, como característica de uma democracia participativa, elegendo novos patamares de equidade socioambiental e política. Também é reconhecida a complexidade dos problemas envolvidos em sua implementação e prática, por isso, seria natural experiências que ainda não atingiram um patamar mais eficaz. Ainda assim, é consenso entre os pesquisadores citados que o OP é uma bem sucedida experiência de participação popular, como um canal de educação para a cidadania ativa, instituindo um espaço público ativo de co-gestão do fundo público e um sistema de partilha do poder com regras de participação e distribuição de recursos, construídos democraticamente entre agentes do Executivo e os vários segmentos da sociedade civil. Por fim, também pode favorecer o exercício do controle social sobre os governantes com regras e critérios objetivos e impessoais para a seleção de prioridades apontadas pela comunidade. Além disso, o OP pode instaurar uma nova cultura política com o aumento da auto-estima do cidadão, pois o torna sujeito do processo político e social da gestão da coisa pública. Nesse momento, de posse de um arcabouço teórico e de discussões de análises de algumas experiências, partiremos para o detalhamento da institucionalização do OP no município de São Carlos, SP (OP/SC). Para tal, iniciaremos com a descrição da localização e ocupação do município, do desenho institucional do OP/SC e da análise de dados. 


\subsection{O município de São Carlos: localização e ocupação}

São Carlos, município localizado na região central do estado de São Paulo (Figura 1), com $1.132 \mathrm{~km}^{2}$ de área e 209.009 habitantes, com um alto percentual da população da área urbana (Quadro 1), está entre os receptores recentes de investimentos industriais e migrantes, geradores de significantes impactos em termos de degradação de suas águas.

O município é cortado por uma extensa rede hídrica, cujo rio principal - Rio do Monjolinho, dá nome à bacia hidrográfica (Figura 1) e um nível de abastecimento de água e de rede de esgoto em níveis acima de 99\% a nível estadual (Quadro 1). Entretanto, grande parte de suas águas foi alterada e/ou degradada, principalmente como fruto do modelo impactante de uma urbanização crescente, gerando, tanto a retirada das suas matas ciliares quanto à poluição, via esgoto doméstico e/ou industrial, entre outras conseqüências.

Esse quadro se configura por conta desse modelo de crescimento desordenado e deletério praticado no município, sem a preocupação com os efeitos que isso pudesse causar ao meio ambiente. O pouco investimento em equipamentos e serviços básicos nas regiões recém ocupadas ampliou a vulnerabilidade tanto dessa parcela da população urbana quanto da base biofísica em que está assentada. A demanda por água alterou-se completamente, tanto quantitativa como qualitativamente, resultante, como no geral, da ausência de uma política urbana sustentável.

Nos últimos quatro anos, a população urbana tem crescido de forma constante, na média de 0,18\%/ano (Quadro 1) e, juntamente com esse aumento, cresce a necessidade de implantação de novos equipamentos de infra-estrutura urbana, além do necessário aumento na quantidade de fornecimento e manutenção da qualidade da água distribuída a essa população.

Com respeito ao abastecimento de água e de redes de esgoto, o município de São Carlos atende praticamente a toda a população (Quadro 1), no entanto, ainda não faz tratamento de seu esgoto, despejando-o diretamente nas águas do Rio do Monjolinho, além de casos de lançamentos clandestinos no próprio rio e em muitos de seus afluentes. Medidas necessárias para a conservação e recuperação dessas águas, impactadas negativamente na ocupação do município, têm sido tomadas, contudo, ainda há muito a se 
fazer. Consideramos, que esse quadro, como ressaltou NEDER (2002), é fruto da concepção sanitária do país, que é baseada na prioridade histórica dada ao abastecimento de água, como pré-condição para a melhoria de condições sanitárias.

Quadro 1 - Caracterização Sociopolítica do Município de São Carlos

\begin{tabular}{l|r|r|r|r}
\hline \hline Área (km²) & \multicolumn{3}{c}{1.132} \\
\hline \hline Demografia & $\mathbf{2 0 0 1}$ & $\mathbf{2 0 0 2}$ & $\mathbf{2 0 0 3}$ & $\mathbf{2 0 0 4}$ \\
\hline População total & 196.607 & 200.657 & 204.791 & 209.009 \\
\hline População urbana & 187.239 & 191.465 & 195.772 & 200.160 \\
\hline População rural & 9.368 & 9.192 & 9.019 & 8.849 \\
\hline Taxa de urbanização (em \%) & 95,24 & 95,42 & 95,60 & 95,77 \\
\hline Densidade demográfica (h/ km²) & 173,68 & 177,26 & 180,91 & 184,64 \\
\hline Saneamento & & & $\mathbf{2 0 0 0}$ \\
\hline & & & Município & Reg.Gov \\
\hline Abastecimento de água - nível de atendimento (\%) & & 99,73 & 99, \\
\hline Esgoto sanitário - nível de atendimento (\%) & & 99,31 & 98, \\
\hline Coleta de lixo - nível de atendimento (\%) & & 99,63 & 99, \\
\hline
\end{tabular}

Fonte: $\underline{\text { wWw.seade.gov.br }}$ 
Figura 1 - Mapa do Município de São Carlos

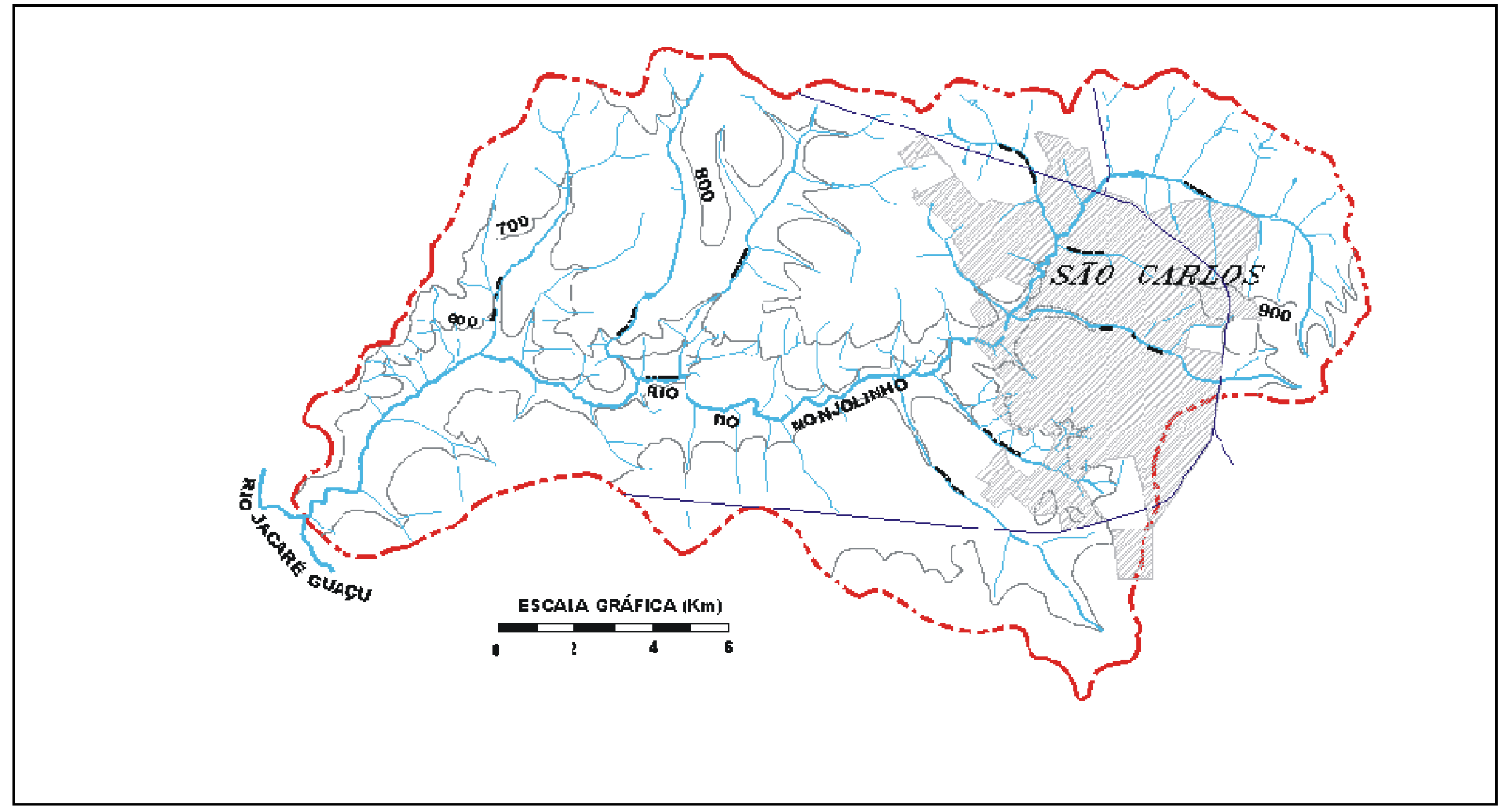

Fonte: Centro de Divulgação Científica e Cultural / CDCC / USP / São Carlos 
Para um melhor entendimento da situação socioambiental do município de São Carlos e dos impactos negativos sofridos pelos seus recursos hídricos, a partir daqui teceremos algumas breves considerações acerca do seu desenvolvimento, esclarecendo o processo de ocupação de seu espaço urbano.

Historicamente, a maioria das cidades surgiu às margens dos rios. O município de São Carlos não fugiu à regra. Cresceu incorporando os seus vários cursos d'água (Figura 2). Assim, o impacto sofrido por estes tem origem no início da urbanização do município, pois recebiam e ainda recebem toda a carga da poluição decorrente dos esgotos domésticos e industriais. Com a urbanização crescente da área em seu entorno, a paisagem sofre seu maior impacto e as águas passam a receber diretamente uma maior carga de poluentes urbanos. A partir da década de 1940 e nas seguintes, o rápido desenvolvimento econômico e urbano tornou a degradação ambiental de origem antrópica, mais visível e intensa. O inchaço do núcleo urbano passa a ser inevitável. Na ausência de um planejamento urbano, ocorre a proliferação de loteamentos periféricos, com a ocupação de áreas impróprias para tal empreendimento. Esses bairros passam, então, a sofrer com a ausência de infra-estrutura urbana e com as conseqüências naturais como assoreamentos, enchentes etc. Com o crescimento industrial cada vez mais acelerado e a falta de incentivo para a população rural permanecer no campo, as décadas de 1960 e 1970 registram um expressivo crescimento da população urbana. Em decorrência dessa urbanização acelerada, os cursos d'água, agora urbanizados, passam a sofrer o seu maior impacto (ALMEIDA, 2001).

A partir de 1980, com o movimento de desconcentração da indústria na capital paulista e região metropolitana, o interior do estado intensifica ainda mais a sua industrialização. Nesse contexto, São Carlos apresenta localização vantajosa para a atividade industrial, atraindo novos empreendimentos, resultantes da facilidade de acesso e de política de incentivo por parte do governo municipal da época, ao lado da atração exercida pela presença de centros de pesquisa científica e tecnológica existentes na cidade.

Como consequiência de todo esse processo, o lançamento de despejos domésticos e industriais tornou o aproveitamento das águas do município impróprio para abastecimento humano, sem o tratamento adequado. Estudos estimam a carga de DBO lançada no rio do Monjolinho em 15 ton/dia (sendo 8 ton/dia de origem doméstica), devido ao esgoto descarregado "in natura” em suas águas, atualmente utilizadas para a geração de energia, 
recepção e escoamento de materiais e resíduos vindos da lixiviação superficial, efluentes industriais diversificados, efluentes agro-industriais (de cana de açúcar, principalmente) e esgotos domésticos (ALMEIDA, 2001).

Conseqüentemente, com o inevitável inchaço do núcleo urbano e a ocupação de seu espaço tradicional gerou-se a verticalização do antigo centro da cidade com o desaparecimento de alguns de seus mais belos e antigos casarões. Por outro lado, aumentou consideravelmente a proliferação de loteamentos periféricos em áreas impróprias como em áreas de mananciais e de cerrado. Além do que, a implantação das marginais gerou um impacto ainda mais negativo para os já descaracterizados cursos d'água urbanos. Esses espaços passam a sofrer ainda mais com a carência de infra-estrutura urbana necessária, essencialmente, por conta da necessidade de uma rápida acomodação dessa população.

Consideramos que essa ocupação rápida e desorganizada do espaço urbano produz baixos níveis de densidade populacional, parcelas territoriais efetivamente desocupadas e altos custos na implantação de serviços públicos, principalmente, sob o ponto de vista da carência parcial ou total desses equipamentos em bairros residenciais mais distantes do centro urbano. Assim, são necessários investimentos para suprir esses bairros dessa infraestrutura, em contrapartida, o município sofre com a insuficiência de recursos para lidar com tal demanda, como a maioria dos municípios brasileiros. Logo, emergem tensões entre requerimentos sociais, a capacidade fiscal de atendê-los e mesmo as condições políticas de comunicar ambas circunstâncias. 
Figura 2 - Mapa de Expansão Urbana do Município de São Carlos

\section{Expansão Urbana}
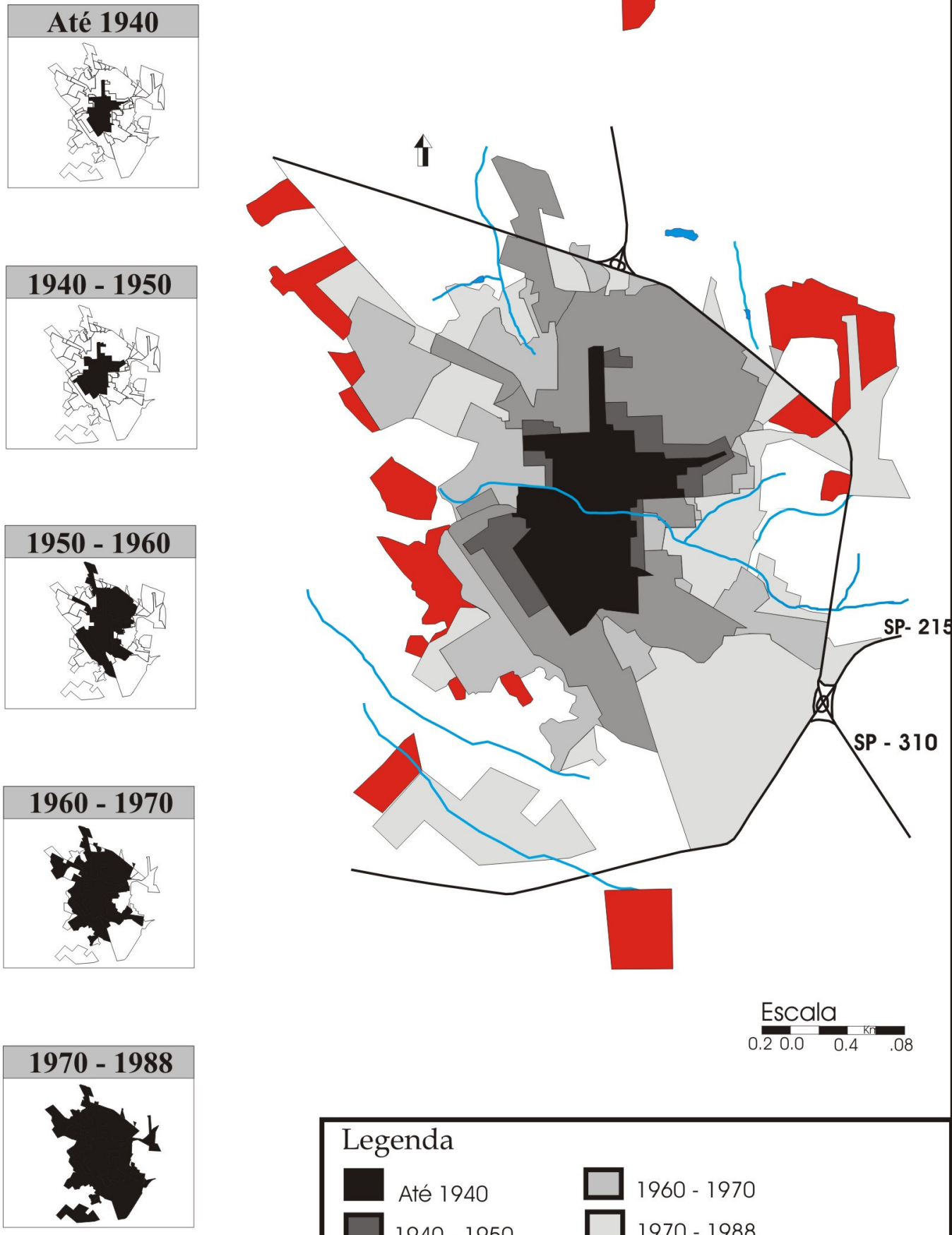

Legenda

$\begin{array}{ll}\square_{\text {Até } 1940} & \square 1960 \text { - } 1970 \\ \square_{1940-1950} & \square_{1970-1988} \\ \square_{1950-1960} & \square \text { Área de Expansão Recente }\end{array}$

Fonte: Almeida, R.C. 2001. 
Já o cenário político são-carlense sofreu modificações a partir de 2000 com a eleição do Partido dos Trabalhadores, que em 2001 institucionalizou o OP. O fato do município ter sido sucessivamente administrado por forças políticas tradicionalistas tem gerado resistência e até um certo distanciamento da população em relação ao OP, por conta dessa tradicionalidade enraizada na esfera política, assim como, nas demais práticas sociais dos cidadãos são-carlenses. Esse quadro histórico é inédito para a sociedade civil local, que pode aproveitar o momento para dar centralidade ao processo de deterioração de sua qualidade de vida, resultante da forma de ocupação tanto da área urbana tradicional, quanto daquela em expansão.

Por conta desse processo de desenvolvimento e ocupação e das condições políticas e socioambientais do município de São Carlos é que o OP, por ser um espaço de participação da gestão pública, pode ser um canal para reivindicações de melhoria desse território já ocupado e de um planejamento partícipe para os que ainda o serão, através das deliberações advindas do Conselho Municipal do OP (COP).

Essa perspectiva se justifica, pois o COP tem por finalidade a fiscalização e elaboração de sugestões para o planejamento e proposta de alterações na composição da receita e da despesa do orçamento do município. Essa interlocução da sociedade civil com o Executivo pode ser a oportunidade que a sociedade civil são-carlense terá em apreciar, emitir opinião e/ou indicar alterações na política tributária e de arrecadação do poder público municipal; no conjunto de obras e atividades constantes do planejamento de governo e orçamento anual; na execução orçamentária anual e no cumprimento do Plano de Investimentos; nos investimentos que o Executivo entenda como necessários para o município e na prestação de contas do governo, ao final de cada exercício. Enfim, o que cabe discutir no OP são as ações de competência do município no que diz respeito aos gastos, projetos e ações acerca da infra-estrutura básica como saúde, transporte, educação, saneamento básico etc.

Atualmente, a maioria dos municípios brasileiros e entre eles se encontra o município de São Carlos, sofre as adversidades da crise econômica - sobretudo em relação ao desinvestimento, desemprego, violência etc. Aliado a isso, a convivência com um quadro fiscal desfavorável - isto é - sem condições de atender às carências sociais que se ampliaram, assim como, de melhorias dos serviços públicos essenciais na saúde, na 
educação, no transporte etc. e, como uma das graves conseqüiências sociais desse quadro, a acelerada deterioração ambiental, principalmente dos recursos hídricos e o estrangulamento do setor de saneamento.

Dentro desse quadro de deterioração ambiental, observamos que a qualidade das águas doces vem continuadamente sofrendo com os impactos negativos, tanto pela riqueza quanto pela pobreza; tanto pela intensidade de acesso e uso dos mananciais quanto pela incapacidade financeira e técnica de gestão adequada das demandas e descartes e esse processo logo pode tornar-se irreversível. O uso mais responsável desse recurso, e a efetiva implantação de políticas públicas, com a correspondente participação da sociedade civil na elaboração e fiscalização no cumprimento dessas políticas, tornaram-se tarefas imprescindíveis, exigindo intervenções rápidas nas práticas sociais. Assim, consideramos que a institucionalização do OP poderia dar conta de ser um espaço privilegiado para a discussão dessa questão entre sociedade civil e poder público. Isso porque é um espaço em que se podem definir gastos no nível municipal, naquilo que diz respeito às questões relativas à água que cabem em sua esfera de atuação como saneamento básico, criação e manutenção de APP's, criação e manutenção de praças e jardins, coleta seletiva etc.

O OP pode ser a resposta para uma participação política mais eficaz desse cidadão na elaboração e implementação de políticas públicas que integrem adequadamente as várias demandas sociais, seja dos vários usuários como o de hidroenergia, abastecimento público, lazer, agricultura, entre outros - seja dos vários segmentos de atuação do Executivo nas quais um melhor uso da água também está diretamente afeito à ação inicial ou final de sua pasta - caso do saneamento, saúde, habitação etc.

Para esse processo ocorrer de forma mais eficaz, a participação do movimento ambiental local é imprescindível. Pois, por um lado, as questões urbanas relativas ao meio ambiente precisam, em muitos casos, de discussão e/ou acompanhamento técnico/teórico antes de serem discutidas e deliberadas e, por outro, esse espaço pode ser uma forma desse movimento ver as questões ambientais urbanas encaminhadas ao poder público com o respaldo e apoio dos vários segmentos da sociedade civil. Assim, consideramos como necessário o esclarecimento de como o movimento ambiental local evoluiu e sua compreensão das questões teóricas até aqui levantadas. 


\subsection{O Movimento Ambientalista no Município de São Carlos}

De nosso ponto de vista, é inquestionável a importância de interlocução do movimento ambiental com o poder público, assim como, o seu significativo papel de divulgação, conscientização e informação das importantes questões ambientais aos vários segmentos da sociedade civil, aliado à participação e respaldo dessa sociedade na promoção e efetivação de suas ações. Consideramos assim, que o movimento ambiental, representando pelas ONG's locais, pode ter um papel importante a desempenhar nas deliberações do OP/SC. Para discutirmos melhor essa questão, faremos um breve histórico do movimento ambiental em São Carlos, fruto das informações fornecidas em entrevistas gravadas com os Senhores Paulo Mancini e Alexandre Rossi ${ }^{4}$.

Segue abaixo a transcrição da entrevista do Dr. Paulo Mancini:

[sobre a fundação da APASC] "A fundação da APASC foi feita por um grupo de alunos da biologia da Universidade Federal de São Carlos / UFSCar na Semana de Estudos Ecológicos, no ano de 1977. Essa semana era para finalizar na fundação de uma entidade e a nossa inspiração era a AGAPAN (ONG ambiental do Rio Grande do Sul, uma das primeiras no Brasil). Naquele momento não exista nenhum movimento ambiental em São Carlos. Hoje existem a APASC, a Teia, a Aquavit e a Biokinesis. O nascimento da APASC tem a ver com a redemocratização do país. Estávamos descontentes com a esquerda tradicional e percebemos no movimento ambientalista, nos ideais ambientalistas, uma coisa muito maior do que a esquerda propunha. A esquerda propunha a justiça social, a luta ambientalista vai muito mais além, justiça social e ambiental, que uma coisa não se faz sem a outra. Além dessa dimensão maior, você continua e até aprofunda todos os ideais de esquerda e ao mesmo tempo facilita, e muito, a ação social, porque você não tem aquele estigma de esquerda e não sofre a repressão, você poder fazer a atividade social sem correr o risco de ser tachado de comunista.

A APASC passou por momentos de dormência por falta de pessoas para movimentar. Acho que falta um trabalho de institucionalização mais forte da APASC. Ela não soube ter um trabalho que produzisse maior enraizamento social. Eu acho que aí foi uma certa falta de tempo das pessoas e uma certa falta de mais coragem. Acho que uma coisa que a gente deveria ter feito logo no início, era começar a promover cursos, porque a educação é tudo. Acho que a APASC não está conseguindo realizar o potencial que ela tem. Mas, certamente pelas condições que a APASC tem ela fez muito pela cidade.

\footnotetext{
${ }^{4}$ Paulo Mancini é Biólogo, Mestre em Hidráulica e Saneamento e um dos fundadores da Associação de Proteção Ambiental de São Carlos / APASC. Atualmente exerce o cargo de Diretor de Políticas Ambientais, da Secretaria de Desenvolvimento Sustentável da Prefeitura Municipal de São Carlos. Alexandre Rossi é Advogado, doutorando em Ciências da Engenharia Ambiental (PPG/SEA/USP) e um dos fundadores da ONG ambiental são-carlense Biokinesis.
} 
[Sobre a participação no OP] Vendo como administrador público, eu acho fundamental você ter entes da sociedade civil organizada para fazer a gestão pública juntos. Porque as entidades civis organizadas elas são entidades públicas, são entidades abertas, às vezes mais públicas que o próprio governo, porque elas são necessariamente apartidárias, são mais plurais.

Eu acho que é muito importante, quando eu participo é como prefeitura, como secretaria. Normalmente é para estar respondendo sobre as seções de meio ambiente. Eu acho que a forma como foram divididas as dinâmicas, não se permite que aja muita divulgação dos trabalhos da prefeitura, pelo menos em detalhe, pode ser que tenha uma divulgação, mas é aquela matéria institucional. Mas, por exemplo, a metodologia usada, não permite que o governo faça a defesa. Por um lado é interessante porque amplia a democracia de certa forma. Mas, por outro lado, é meio sacrificante, meio penoso, porque, exatamente quem, pela perspectiva que está vivendo, tem melhores condições de opinar, não pode. Porque, você está vendo todos os lados da situação, às vezes a pessoa que está ali vê de sua perspectiva, da casa dela, está vendo a cidade a partir da casa dela. Você não, você está vendo a cidade plural mesmo. Mas eu sinto assim que é uma coisa que aos poucos vai ganhando corpo.

Eu, particularmente, acho o OP um instrumento fantástico para a educação ambiental. Eu sempre falo que a gente não pode perder a oportunidade de estar organizando a população local para ir ao OP reivindicar as nossas demandas ambientais dentro do bairro, dentro da região. Só que eu não tenho conseguido fazer isso, por excesso de atividade, ou por falha.

[sobre a percepção dos participantes do OP sobre a questão ambiental] $O$ que eu acho o problema da APASC hoje é ter poucos quadros, muito qualificado, mas são poucos para estar participando de todas as reuniões do OP. O problema hoje da dificuldade de uma participação maior é essa. Mas eu acho que a entidade deveria ter uma diretriz de procurar participar das reuniões de OP, procurar levantar os problemas ambientais. Eu acho que seria uma voz respeitada porque ainda que ela não esteja participando com voto, mas ela poderá falar, ela pode ajudar orientar o processo de votação, esclarecer o debate. Outro ponto é que a grande mídia ela não ajuda em nada, porque ela divulga as questões ambientais de uma forma muito caricata, a mata, o bichinho, muito pontual, precisa proteger as matas. Bom, eu não tenho nem quintal, o que eu tenho que proteger as matas, é coisa do governo, só pode ser coisa do governo. Eles podem estar

pedindo aquela obra, mas eles não têm consciência de que é uma obra ambiental. Ele pede uma limpeza ambiental porque ele tem noção que se ele pedir o que ele quer, ele não vai conseguir, porque o que ele quer mesmo é canalizar, tampar, colocar uma valeta em cima."

\section{Segue abaixo a transcrição da entrevista do Sr. Alexandre Rossi:}

[sobre a fundação da Biokinesis] "A Biokinesis surge em 1999 por pessoas ligadas às universidades e centros de pesquisa de São Carlos, que já tinham uma sensibilidade para a questão ambiental, mas não participavam de nenhuma entidade. A APASC tinha um foco muito meritório, inestimável na cidade, nas questões locais. E embora esse grupo de pessoas apoiasse isso, tinham o anseio de participação em uma entidade mais genérica, eram pessoas que trabalhavam com as questões mais globais". 
[sobre a participação no OP] Nós fomos a algumas reuniões. Eu considero um avanço, já transcendeu os limites de uma bandeira partidária. É uma conquista que está aí e não pode se perder é uma coisa que não tem volta, as pessoas aprenderam a participar quem agora tentar tirar isso vai encontrar problemas. Por outro lado eu acredito que precisa ser aperfeiçoado. No afã de tornar a reunião do OP ser participativa, ou seja, de ser aberta a todos, algumas vezes elas se tornam flexíveis demais, algumas pessoas tomam a palavra e não há limite para elas falarem. Muitas vezes vira aquele momento de catarse, a pessoa nunca foi ouvida de repente passa a ser ouvida. Pedem tudo que vem à cabeça, sem antes fazer um filtro de prioridades, de possibilidades e dá a impressão que tudo aquilo vai ser feito no momento seguinte e o orçamento tem limites. E como a nossa cultura ainda é muito imediatista, as pessoas tendem a se frustrar com esse processo. Essa é a leitura que eu tenho tido. Existe uma grande diversidade nas reuniões, o que é uma riqueza, mas traz um problema. E aí é que entra um papel muito importante das entidades ambientalistas atuarem nesse espaço. Hoje se você chamar a população para uma reunião geral, sobre a questão da água, nós temos córregos que cortam nossa cidade, qual a prioridade? Eles vão falar, canalizar e fazer avenidas. Coisa que nós já temos clareza que é a pior das intervenções, que gera grandes problemas. São Carlos é um exemplo latente desses problemas e ainda assim uma parcela significativa da população não consegue perceber. Ainda que já avançamos um pouco e já tem muita gente que entende que não pode se fazer o que foi feito aqui, isto é, além de canalizar curso d'água, ainda constrói centro comercial em cima. Mas ainda tem reuniões que as pessoas vão cobrar isso (canalização). O papel das entidades ambientalistas é estar nesses fóruns demonstrando o porque das coisas, que problemas estão envolvidos. Mas aí precisa encontrar os meios adequados para fazer essa intervenção de esclarecimento.

Quando você é uma pessoa isolada que vai participar de um fórum desses, é natural que eu peça a palavra e coloque uma posição naquele momento ali como cidadão, que vai ser somado com uma série de outras. Eu entendo que a entidade tem um papel diferente, ela pode ter um representante que se inscreva e manifeste a posição da entidade, que já tem outro peso. Mas ela não pode ficar só nisso, ela tem que fazer o antes e o depois.

Ou seja, uma entidade que vai para uma reunião do OP, ela tem que antes ter discutido isso, com as suas bases, tem que ter feito estudos para isso, tem que ter feito uma massificação dessa idéia, divulgando-as. Para quando ela chegar nessa reunião chegar com esse peso do antes para naquele momento para defender aquela posição. Se possível ela tem que divulgar para os participantes sua posição até antes da intervenção. E depois, o momento dela não pode se esgotar, ela tem que dar uma continuidade, acompanhar a discussão orçamentária, acompanhar na câmara a aprovação e até fazer uma avaliação de como isso se deu para intervenções no exercício seguinte. Também tem que levar em conta o seguinte, que a entidade vai com uma posição para o OP, mas ela vai ter que abrir mão de algumas coisas, porque é um processo de composição, mas ela tem que continuar trabalhando para aquela meta.

Isso eu acho que dá um outro posicionamento para as entidades. Eu como membro de uma entidade reconheço que nós não fazemos tudo isso, que deveríamos fazer. Nós vamos muitas vezes para a reunião do OP falando como entidade, mas agindo como indivíduo. 
O movimento ambiental da década de 60/70, da ditadura militar, tinha um desafio, que era um ato de contradição, que era se abraçar na árvore, ficar de braço dado na frente do trator. Isso hoje não é mais o contexto, tirando uma ou outra situação extremamente isolada. Hoje a discussão é outra, é uma discussão mais técnica, muito mais científica. Eu acho que hoje estamos em outro momento, que é levar informação, mas não meramente informação, porque hoje as pessoas estão com excesso de informação. Se fala de meio ambiente todo dia na televisão, a imprensa regional precisa desse assunto, mas se fala de uma maneira acrítica. Acho que o papel nosso hoje, é levar a informação qualificada, a discussão e a reflexão para todos os setores, para toda a população. Acho que o nosso desafio hoje é um outro degrau, é um outro degrau de intervenção. $O$ OP pode ser esse espaço, mas não pode fazer no dia e na hora da reunião apenas. Eu acho que uma $O N G$ que quer intervir no $O P$, ela tem que se estruturar, sozinha ou em parcerias com a articulação entre as várias entidades, para criar uma estrutura de intervenção. Nós temos que trabalhar isso na população muito antes, senão vai virar aquela coisa que não vai virar em termos de conscientização. Esse éo papel do movimento ambientalista, é fazer essa intervenção."

Através da fala desses dois representantes do movimento ambiental local, percebemos a importância que eles vêem na participação desse movimento no interior do OP/SC, corroborando com nossa afirmação anterior da relevância na participação das ONG's locais. De nossa perspectiva e também dos Srs. Paulo Mancini e Alexandre Rossi, o OP/SC pode ser a oportunidade para a sociedade civil são-carlense deliberar ações, a fim de se chegar a uma cidade com mais equidade socioambiental. Para que tal perspectiva se concretize, é mister o esclarecimento das questões ambientais mais urgentes do município, gerando, em contrapartida, atitudes mais conscientes e eficazes no momento de solicitar e deliberar demandas que poderão interferir no ambiente urbano, principalmente no que diz respeito aos já tão impactados cursos d'água do município.

De posse do arcabouço teórico e de análises de experiências práticas levantadas até o momento, passaremos a descrever o desenho institucional do OP/SC e, a seguir, a análise dos dados colhidos pela pesquisadora, durante os anos de 2001 a 2004. 


\subsection{Desenho institucional do Orçamento Participativo de São Carlos}

\subsubsection{O processo participativo ${ }^{5}$}

De acordo com as diretrizes teóricas do Orçamento Participativo do município de São Carlos (OP/SC), seu principal objetivo é promover uma nova dinâmica e estabelecer um mecanismo sustentado de gestão conjunta dos recursos públicos, através de decisões partilhadas sobre a distribuição dos fundos orçamentários e de responsabilização administrativa no que diz respeito à efetiva implementação dessas decisões. A estrutura do OP/SC tem no Conselho Municipal do Orçamento Participativo - COP, um órgão de participação da comunidade cuja finalidade é fiscalizar, elaborar sugestões para o planejamento e propor alterações para a composição da receita e da despesa do orçamento municipal e o percentual do orçamento municipal direcionado ao OP é oriundo de seu total para investimentos e varia ano a ano, de acordo com a arrecadação total.

O OP/SC está articulado em torno das Assembléias Gerais Populares Regionais e Temáticas (fase informativa), Assembléias Gerais Populares (fase deliberativa), dos Fóruns de Delegados e do COP. São promovidas duas assembléias plenárias em cada uma das $13^{6}$ regiões e em cada uma das quatro áreas temáticas: Educação, Esporte, Cultura e Lazer; Saúde e Cidadania; Desenvolvimento Urbano e Desenvolvimento Sustentável. As assembléias têm três finalidades principais: definir e escalonar as exigências e as prioridades regionais ou temáticas; eleger os delegados e os conselheiros do COP; avaliar o desempenho do Executivo. Os delegados funcionam como intermediários entre o COP e os cidadãos, individualmente ou como participantes das organizações comunitárias e temáticas (Quadro 6). Também supervisionam a implementação do orçamento. Os conselheiros definem os critérios gerais que presidem ao escalonamento das exigências e à distribuição dos fundos e votam a proposta do plano de investimento apresentada pelo Executivo (Quadro 6).

Para um trabalho mais eficaz, a cidade foi dividida em regiões de acordo com critérios baseados na infra-estrutra urbana, isto é, regiões formadas por bairros que são dependentes entre si, como comunidades que utilizam a mesma infra-estrutura (creche, posto de saúde,

\footnotetext{
5 A organização desse sub-item foi baseada em SANTOS (2002, pp. 467-500) para discussão do desenho institucional do OP/Porto Alegre.

${ }^{6}$ Divisão válida a partir do ano de 2002, no ano de 2001 o total era de 14 regiões.
} 
escola, transporte etc.) e/ou são configurados pela mesma malha viária (Figura 3; Quadro 2). Nesse processo existiu a participação das comunidades dos bairros que puderam solicitar mudanças e/ou adequações nas regiões.

Uma característica importante dessa divisão merece ser ressaltada, pois uma mesma região pode comportar bairros considerados de baixo, médio até de alto padrão. Essa heterogeneidade sócio-econômica e cultural no interior das regiões pode levar, entre outras a estas questões:

(a) dificuldade de integração ou entendimento entre moradores;

(b) regiões onde convivem bairros periféricos carentes de infra-estrutura básica com condomínios de alto padrão, isentos desse tipo de problema;

(c) formação de grupos, tanto de bairros desassistidos quanto de condomínios de alto padrão;

(d) desconhecimento das principais demandas totais da região por parte de alguns bairros e de bairros para bairros. 
Figura 3 - Divisão Regional do OP / Área Urbana do Município de São Carlos

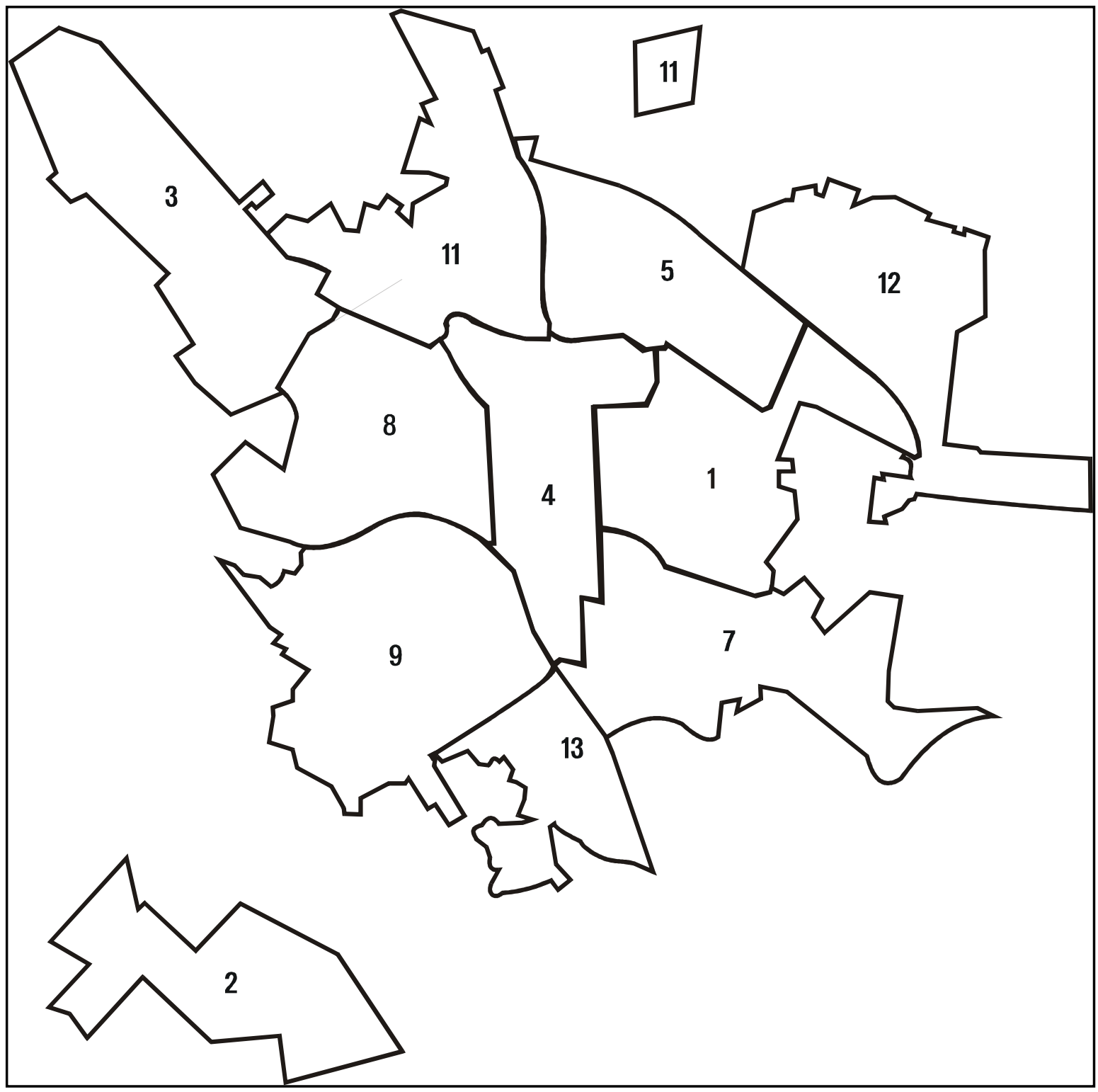

Fonte: Prefeitura Municipal de São Carlos, Secretaria de Desenvolvimento Urbano, 2004. 
Quadro 2 - Divisão Regional do OP por Bairros / Área Urbana

\begin{tabular}{|c|c|}
\hline $\mathbf{R}$ & Bairros \\
\hline 01 & $\begin{array}{l}\text { V1. Nery, Vl. Derigge, Vl. Sto Antonio, Pq. Sabará, Conjunto Residencial Américo A. } \\
\text { Margarido, Convívio D. Bosco, Jd. Cardinalli, Pq. Primavera }\end{array}$ \\
\hline 02 & Cidade Aracy I e II, Antenor Garcia, Presidente Collor \\
\hline 03 & $\begin{array}{c}\text { Santa Felícia, Arnon de Mello, Santa Angelina, Aracê de Santo. Antonio I e II, } \\
\text { Morada dos Deuses, Parque Fehr, Parque Iguatemi, Residencial Paraty, Residencial } \\
\text { Romeu Tortorelli, Santa Cruz, São Carlos I, II, III e IV }\end{array}$ \\
\hline 04 & $\begin{array}{l}\text { Centro, Cidade Universitária, Conjunto Habitacional Sílvio Villari, Jardim Lutfalla, } \\
\text { Jardim Macarenco, Vila Elizabeth }\end{array}$ \\
\hline 05 & $\begin{array}{l}\text { Vl São José, Jardim São João Batista, Jardim Santa Maria I, Tijuco Preto, Nova } \\
\text { Estância, Chácara Paraíso, Parque Estância Suíça, V1 Costa do Sol, Vl Jacobucci, }\end{array}$ \\
\hline 06 & Distrito de Santa Eudoxia \\
\hline 07 & $\begin{array}{l}\text { Castelo Branco, Vila Monteiro, V1 Marcelino, Azuville I e II, Centreville, Jardim } \\
\text { Nova São Carlos, Jardim Ricetti, Parque Itaipu, Vl Alpes, Vl Irene, V1 Lutfalla }\end{array}$ \\
\hline 08 & Planalto Paraíso, Jardim São Carlos, Parque Santa Mônica, Parque Faber \\
\hline 09 & $\begin{array}{c}\text { V1 Prado, V1 Boa Vista, V1 Bela Vista, Jd Botafogo, Jd Beatriz, Jd Medeiros, Jd das } \\
\text { Torres, Mirante Bela Vista, V1 Carmem, V1 Pelicano }\end{array}$ \\
\hline 10 & Água Vermelha, Tutoya do Vale, Tibaia S. Fernando I /II, Valparaíso I/II \\
\hline 11 & $\begin{array}{c}\text { Jd Nova Sta Paula, Jd Jockey Club, Jd Centenário, Cidade Jardim, Santa Marta, Jd } \\
\text { Bandeirantes, Jd Hikare, Paulistano, Santa Paula, Parque Delta }\end{array}$ \\
\hline 12 & $\begin{array}{c}\text { Parque Residencial Maria Stella Fagá, Jd Tangará, Jd Santa Maria II, Babilônia, Jd } \\
\text { Munique, Parque Belvedere, Residencial Itamaraty }\end{array}$ \\
\hline 13 & Jd. Cruzeiro do Sul, Jd Gonzaga, Jd Pacaembu, Jd. Monte Carlo, Santa Madre Cabrir \\
\hline
\end{tabular}




\subsubsection{Sobre o funcionamento das Assembléias}

As duas rodadas das Assembléias (Geral Popular Regional e Temática e Geral Popular) são anuais e estão abertas à participação de qualquer citadino e aos representantes de organizações civis e de associações e também têm a presença de membros do Executivo (prefeito e/ou secretários municipais) e são coordenadas por membros do governo municipal, bem como pelos delegados e conselheiros do OP.

A 1. ${ }^{a}$ Assembléia Geral Popular Regional (fase informativa) tem por objetivos a prestação de contas do ano anterior e o levantamento das demandas da região. No que se refere aos critérios para definição de obras, as Assembléias Regionais levantam em uma primeira reunião quais as carências de obras e serviços da região. Após esse primeiro levantamento, as Secretarias Municipais analisam cada necessidade levantada, segundo critérios técnicos de viabilidade, custo de implantação e, se for o caso, manutenção pósconclusão da obra.

$\mathrm{Na}$ 2. ${ }^{\mathrm{a}}$ Assembléia Geral Popular (fase deliberativa), o Executivo apresenta os princípios mais importantes da política fiscal e da política de receitas e despesas que irão influenciar a preparação do orçamento para o ano seguinte, assim como, critérios gerais para a distribuição dos recursos de investimento. Nesse momento, são votadas as cinco prioridades temáticas e as quatro obras em ordem de prioridade. Executadas todas essas etapas, o COP pontuará as prioridades segundo critérios e pesos pré-estabelecidos (Quadro 3), sendo: número de habitantes da região (2); carência (4); prioridade temática da região (4); prioridade de obras da região (4).

Também na 2. ${ }^{\text {a }}$ Assembléia Geral Popular (fase deliberativa), são definidos o número de delegados das regiões e plenárias temáticas segundo critério de proporcionalidade (Quadro 4). Também são eleitos os conselheiros das regiões e das plenárias temáticas, coordenadas pela Administração Municipal sendo que:

- as inscrições de chapas para conselheiros somente serão aceitas quando estiverem completas, com indicação de dois titulares e dois suplentes e deverão ser realizadas na $1 .^{a}$ Assembléia Regional ou Temática;

- as chapas inscritas deverão passar por um breve curso de formação, antes da eleição que ocorrerá na 2. ${ }^{a}$ fase do processo; 
- havendo mais do que duas chapas, a eleição ocorrerá em dois turnos, aplicando-se a tabela de proporcionalidade apenas no segundo turno, com as duas chapas vencedoras do primeiro turno;

- se no primeiro turno uma chapa obtiver mais do que $85 \%$ dos votos não será necessário segundo turno; no caso de duas chapas para a eleição dos conselheiros, será aplicada a tabela de proporcionalidade (Quadro 4);

- as regiões e plenárias temáticas definirão o número de seus delegados na $2 .^{\text {a }}$ Assembléia Geral Popular (2. rodada) na proporção detalhada no Quadro 5;

- os conselheiros representantes das Associações de Bairros e dos Sindicatos de São Carlos serão indicados em assembléias organizadas pelas próprias entidades, em data acordada com antecedência de 48 horas com a Coordenação do OP.

Após o primeiro ano de implantação, foram detectadas por parte do COP algumas dificuldades na fase deliberativa. Por conta disso, iniciou-se a partir do ano de 2002 e finalizadas no ano de 2003 algumas modificações estruturais.

O COP detectou que o critério de pontuação não permitia grandes obras, assim, a partir de 2002 foi implantada a primeira mudança denominada "critério de coincidência". São promovidas as reuniões temáticas onde se elegem prioridades em cada temática e, posteriormente, encaminhadas para as reuniões regionais. Nesse momento, dentre as obras regionais são também consideradas as obras temáticas, isto é, as grandes obras que abrangem mais de uma região e os participantes passam a ter a opção de elegê-las ou não.

Já a partir de 2003, o processo de pesos foi definitivamente substituído pela eleição direta das obras nas regiões. É um critério de distribuição de recursos por região, de acordo com o número de habitantes de cada uma delas. Dessa forma, os participantes podem escolher as obras necessárias em conformidade com os recursos disponíveis. Esse processo eliminou a dificuldade relatada pelos participantes na compreensão da "matemática" desse sistema, tornando-o mais claro e transparente. Além disso, esse novo sistema permite o controle pelos participantes dos valores disponíveis e custos das obras solicitadas por cada região. 


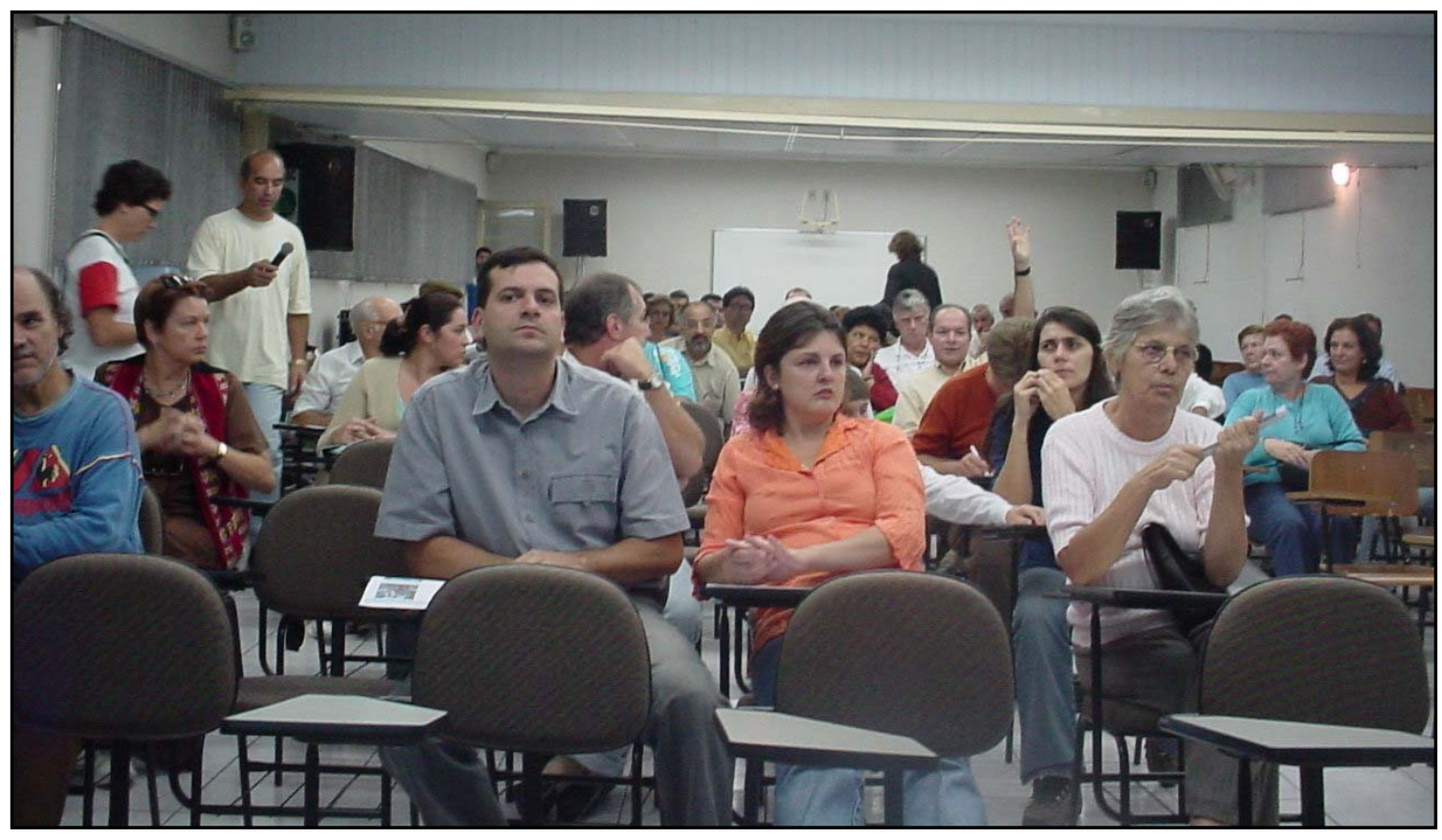

Figura 4 - Reunião de Conselheiros e Delegados do OP / Fase Deliberativa

Fonte: Coordenação do OP/SC

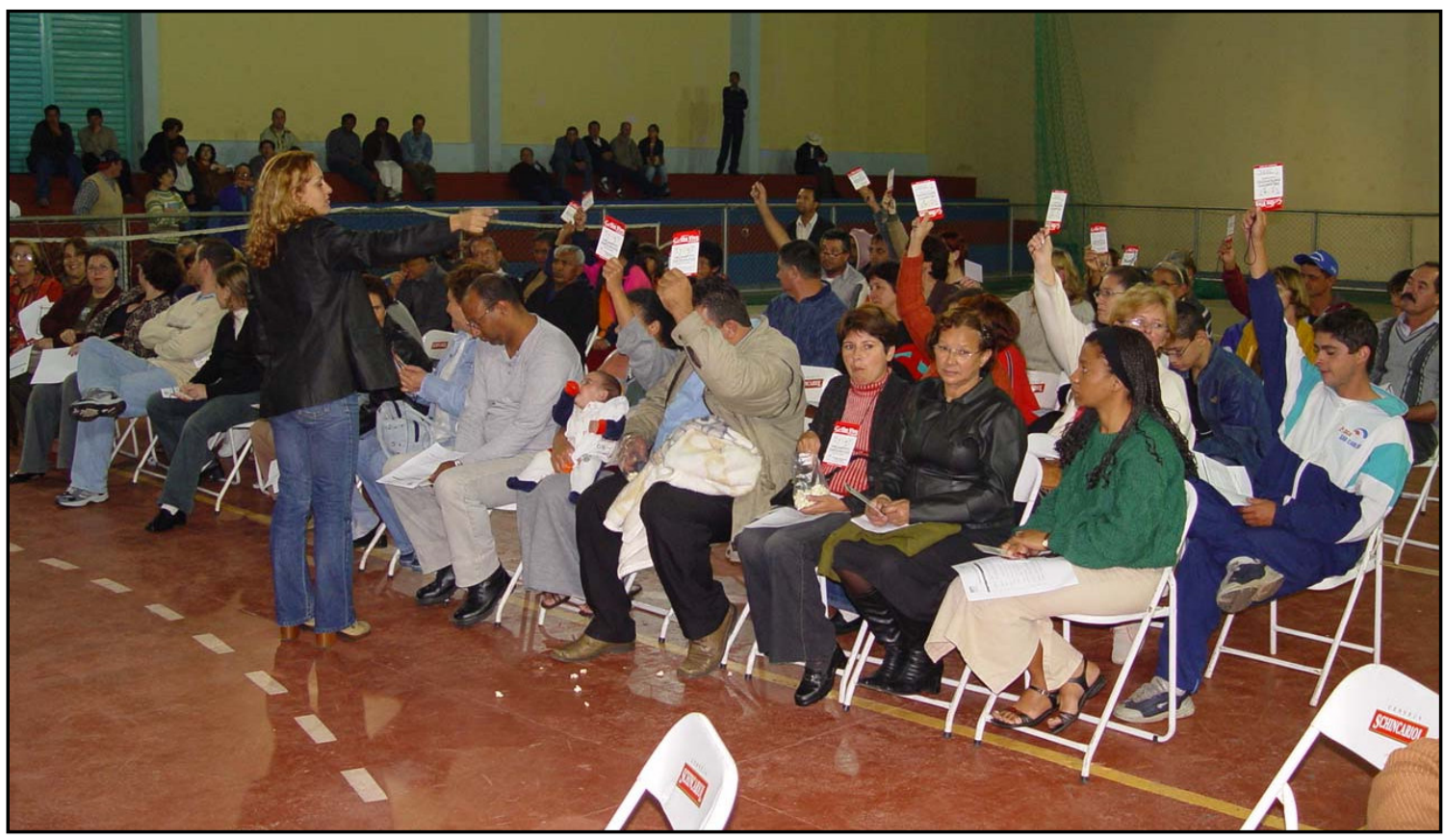

Fonte: Coordenação do OP/SC

Figura 5 - Reunião da Comunidade de uma das regiões do OP / Fase Informativa 


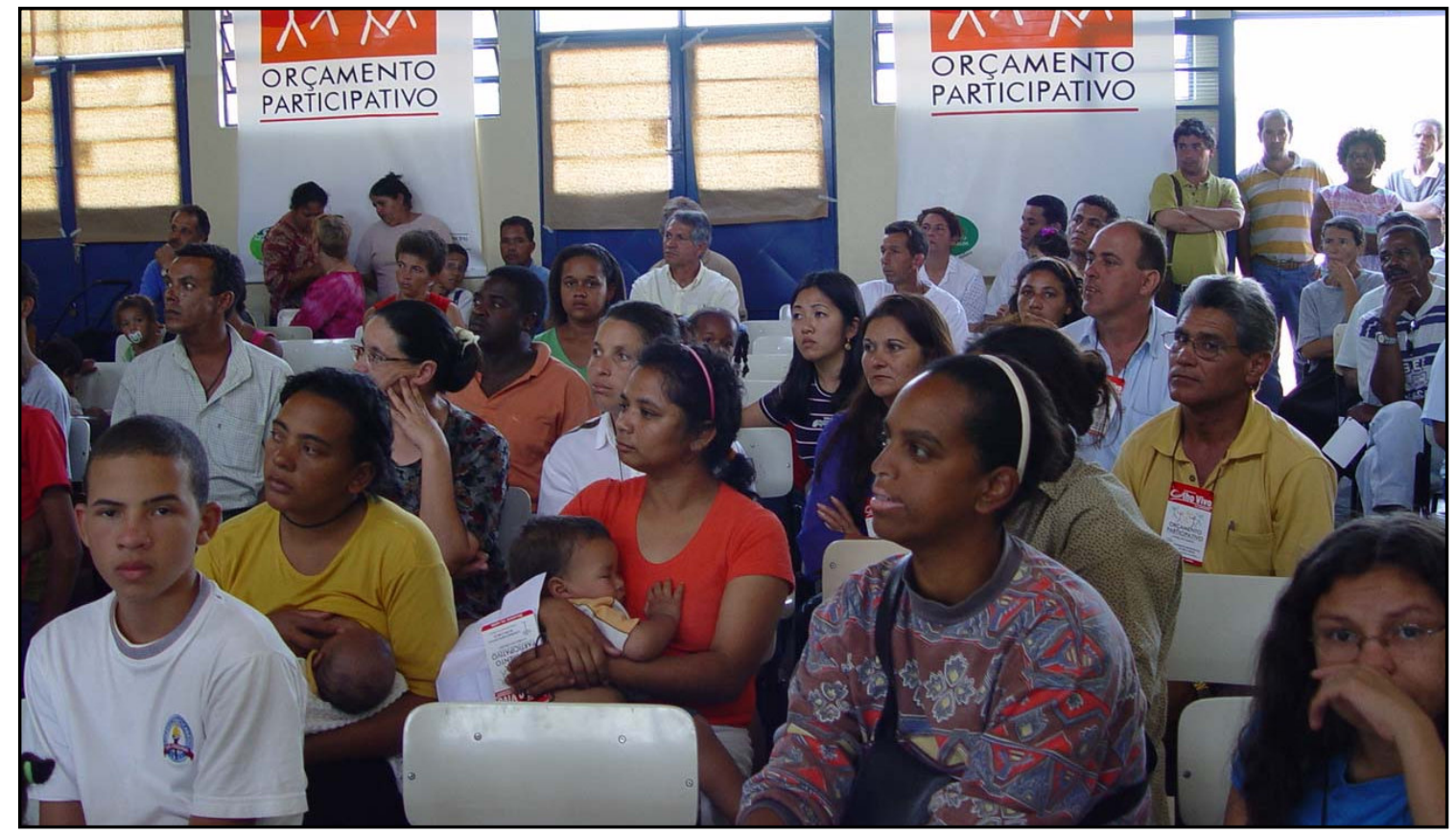

Fonte: Coordenação do OP/SC Figura 6 - Reunião da Comunidade de uma das regiões do OP / Fase Informativa

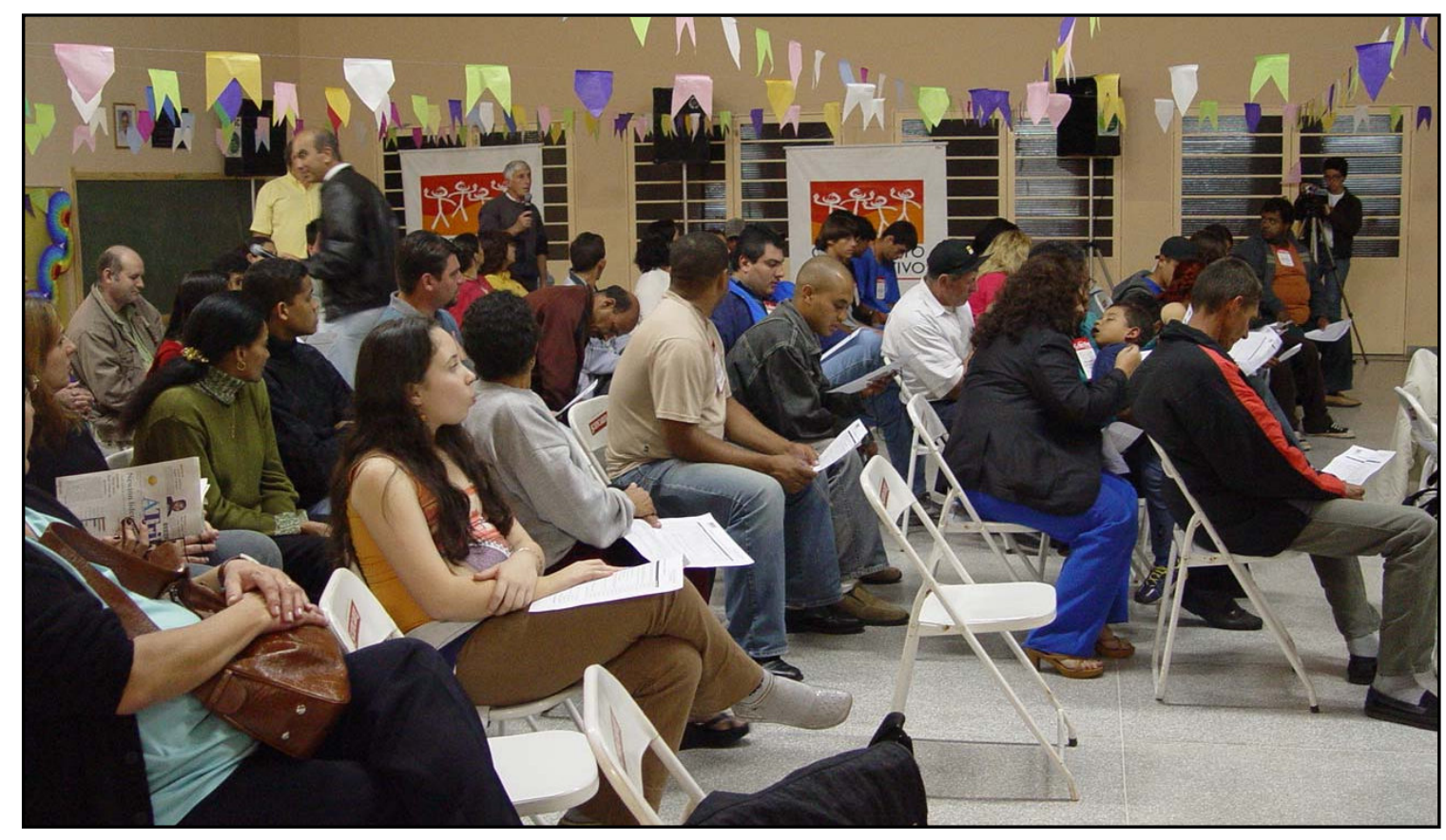

Figura 7 - Reunião da Comunidade de uma das regiões do OP / Fase Informativa

Fonte: Coordenação do OP/SC 


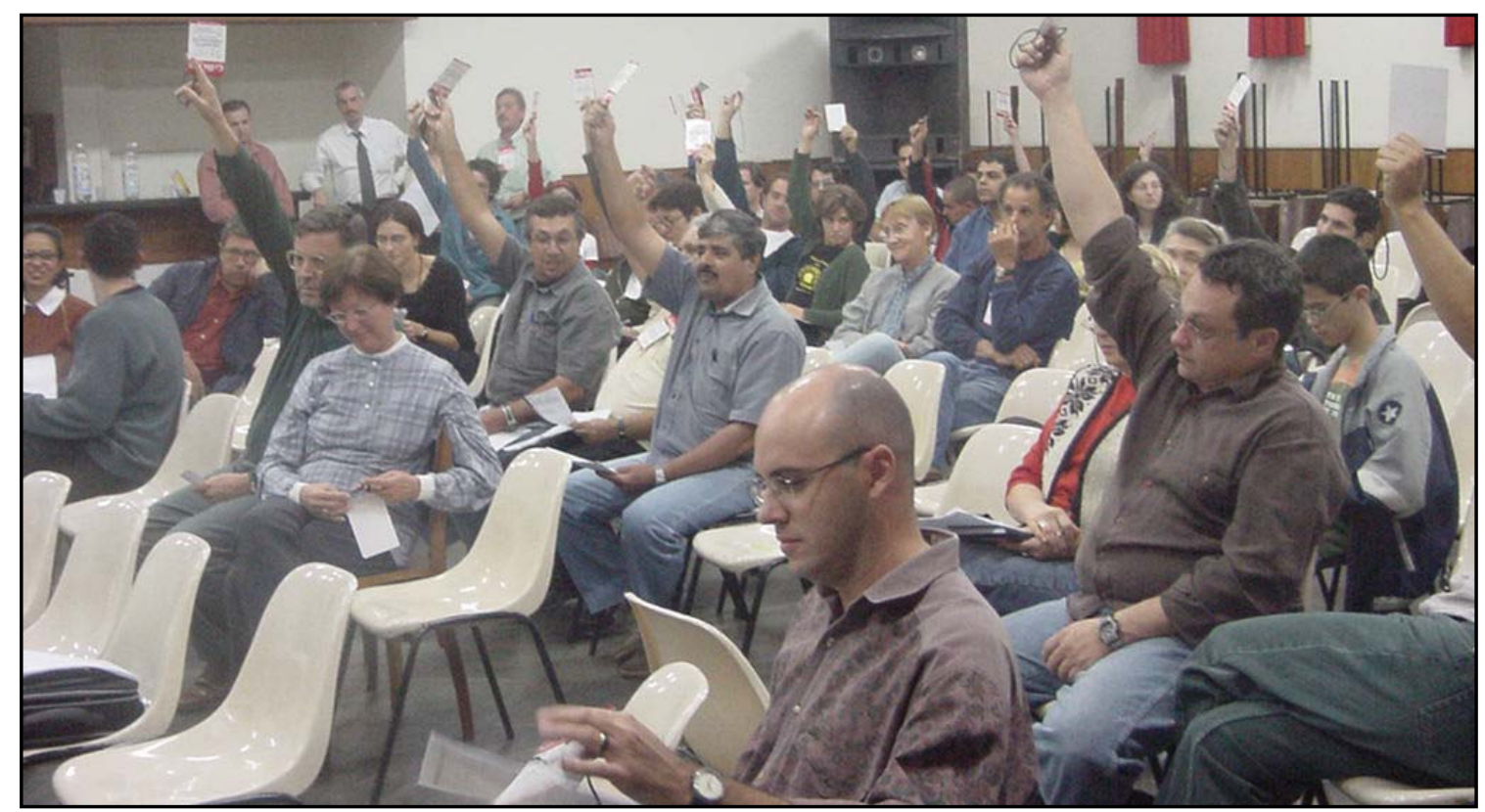

Fonte: Coordenação do OP/SC

Figura 8 - Reunião de Conselheiros e Delegados do OP / Fase Deliberativa

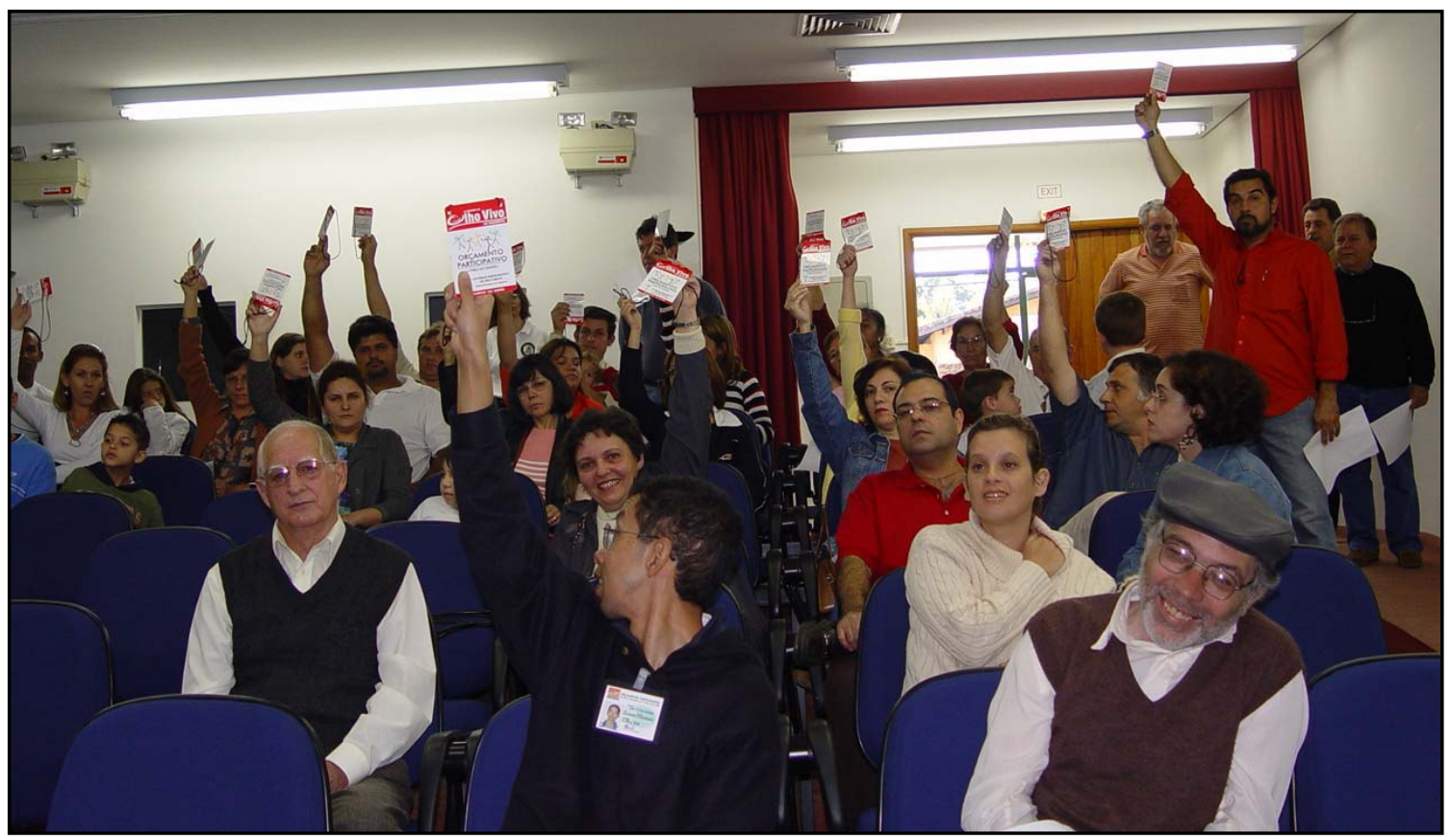

Fonte: Coordenação do OP/SC

Figura 9 - Reunião de Conselheiros e Delegados do OP / Fase Deliberativa 


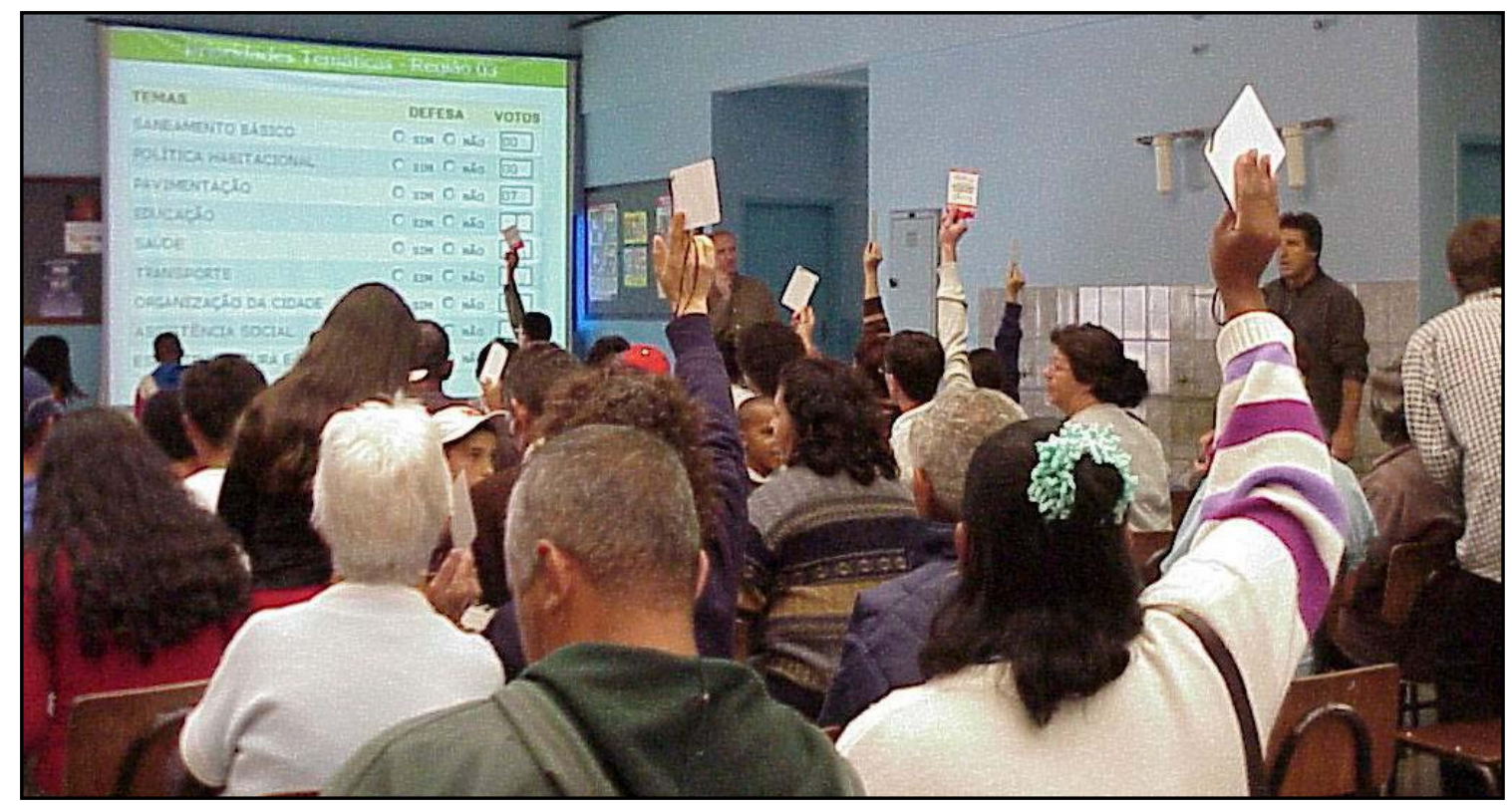

Figura 10 - Reunião de Conselheiros e Delegados do OP / Fase Deliberativa

Fonte: Coordenação do OP/SC

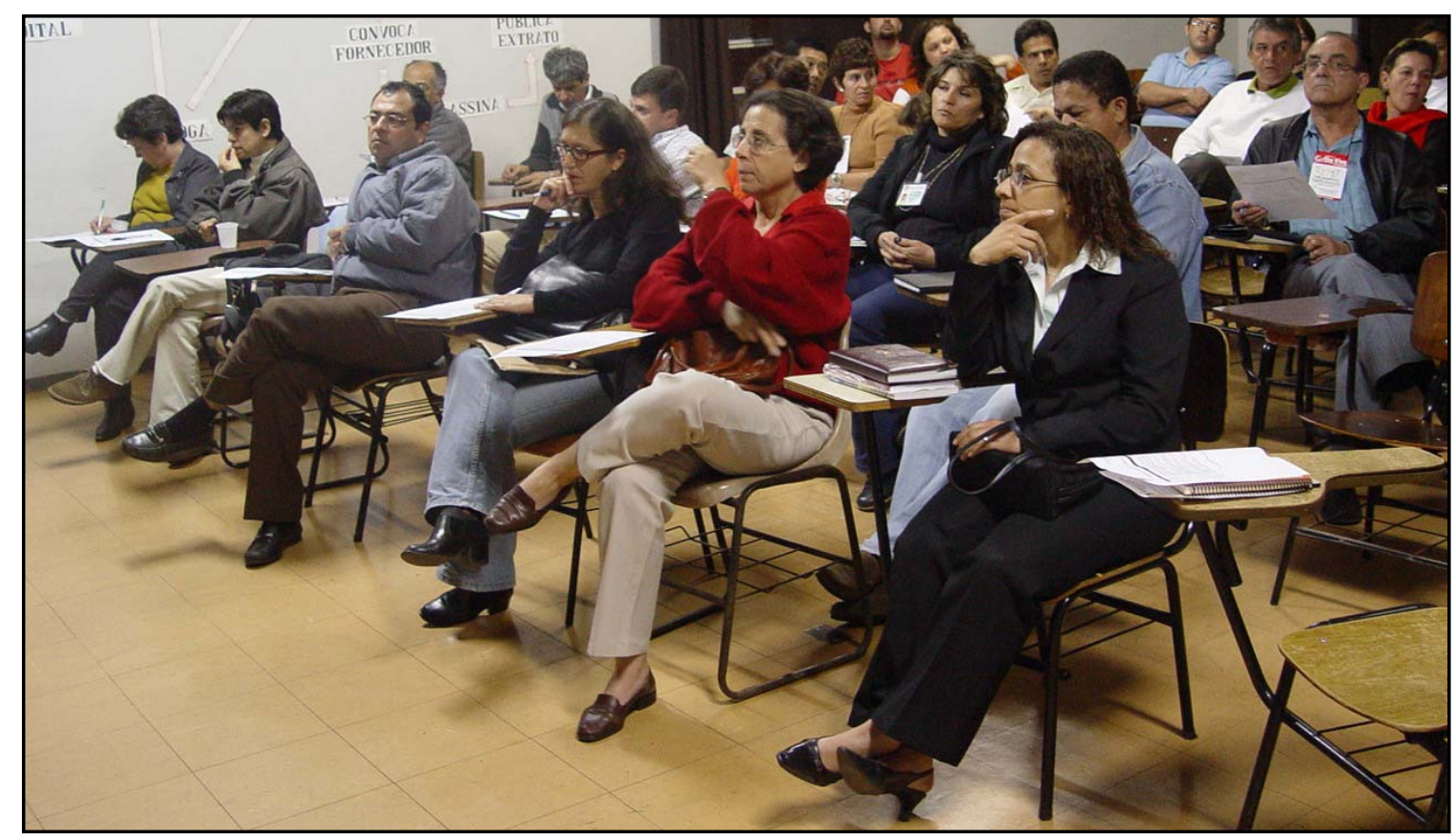

Figura 11 - Reunião de Conselheiros e Delegados do OP / Fase Deliberativa

Fonte: Coordenação do OP/SC 
Quadro 3 - Critérios, pesos e notas para distribuição dos investimentos

\begin{tabular}{|c|c|}
\hline \multirow{2}{*}{$\begin{array}{c}\text { Carência } \\
\text { (de acordo com a Planta Genérica de Valores) }\end{array}$} & Peso 4 \\
\hline & Nota \\
\hline 39 e 40 & 1 \\
\hline De 34 a 38 & 2 \\
\hline De 28 a 33 & 3 \\
\hline De 20 a 27 & 4 \\
\hline De 01 a 19 & 5 \\
\hline População total da Região & Peso 2 \\
\hline (de acordo com o número de ligações de água do SAAE) & Nota \\
\hline Até 2.000 habitantes & 1 \\
\hline De 2.001 a 4.000 & 2 \\
\hline De 4.001 a 6.000 & 3 \\
\hline Acima de 6.001 & 4 \\
\hline \multirow[t]{2}{*}{ Prioridade Temática da Região } & Peso 4 \\
\hline & Nota \\
\hline Quinta prioridade & 1 \\
\hline Quarta prioridade & 2 \\
\hline Terceira prioridade & 3 \\
\hline Segunda prioridade & 4 \\
\hline Primeira prioridade & 5 \\
\hline \multirow[t]{2}{*}{ Prioridade de Obras da Região } & Peso 4 \\
\hline & Nota \\
\hline Primeira prioridade & 4 \\
\hline Segunda prioridade & 3 \\
\hline Terceira prioridade & 2 \\
\hline Quarta prioridade & 1 \\
\hline \multicolumn{2}{|l|}{ Critérios de Desempate } \\
\hline Prioridade de obras & Votada \\
\hline Carência & Pontuação pré-estabelecida \\
\hline População & Pontuação pré-estabelecida \\
\hline Temática & votada \\
\hline
\end{tabular}


Quadro 4 - Tabela de Proporcionalidade para a eleição de conselheiros do COP (no caso de existir mais de uma chapa)

\begin{tabular}{c|c|c}
\hline Percentual de votos & Titular & Suplente \\
\hline mais de $85 \%$ & 2 & 2 \\
\hline $62,6 \%$ a $85 \%$ & 2 & 1 \\
\hline 55,1 a $62,5 \%$ & 2 & 1 \\
\hline $45 \%$ a $55 \%$ & 1 & 2 \\
\hline $37,6 \%$ a $44,9 \%$ & Nenhum & 1 \\
\hline $15 \%$ a $37,5 \%$ & Nenhum & Nenhum \\
\hline menos de $15 \%$ & Não elege & \\
\hline
\end{tabular}

Quadro 5 - Tabela de proporcionalidade de delegados das regiões e plenárias temáticas

\begin{tabular}{c|c|c}
\hline Faixas & Critérios & Delegados \\
\hline Até 100 & 1 para 10 & +10 \\
\hline 101 a 250 & 1 para 20 & +8 \\
\hline 251 a 400 & 1 para 30 & +5 \\
\hline 401 a 550 & 1 para 40 & +3 \\
\hline 551 a 700 & 1 para 50 & +3 \\
\hline 701 a 850 & 1 para 60 & +2 \\
\hline 851 a 1000 & 1 para 70 & +1 \\
\hline Acima de 1000 & 1 para 70 & +4 \\
\hline
\end{tabular}




\section{Quadro 6 - Detalhamento do Regimento Interno do OP / São Carlos}

\section{Conselho do Orçamento Participativo - COP}

\begin{tabular}{|c|c|}
\hline & $\begin{array}{l}2 \text { conselheiros titulares e } 2 \text { conselheiros suplentes eleitos em cada uma das regiões } \\
\text { da cidade; } \\
2 \text { conselheiros titulares e } 2 \text { conselheiros suplentes eleitos em cada uma das plenárias } \\
\text { temáticas; } \\
1 \text { representante e } 1 \text { suplente dos sindicatos dos Trabalhadores de São Carlos } \\
\text { (indicados em assembléias organizadas pelas próprias entidades); } \\
1 \text { representante e } 1 \text { suplente da União das Associações de Moradores de São Carlos } \\
\text { ou entidade respectiva (indicados em assembléias organizadas pelas próprias } \\
\text { entidades); } \\
2 \text { representantes do Executivo Municipal (indicados pelo Prefeito Municipal e sem } \\
\text { direito a voto). }\end{array}$ \\
\hline Critérios & $\begin{array}{ll}\text { - } & \text { munícipes de São Carlos; } \\
\text { - } & \text { moradores(as) da região em que serão candidatos(as); } \\
\text { - } & \text { maiores de } 16 \text { anos; } \\
\text { - } & \text { não sejam detentores(as) de mandato eletivo nos Poderes Legislativo ou Executivo; } \\
\text { - } & \text { não tenham cargo em comissão, de confiança ou função gratificada nos poderes } \\
& \text { públicos municipal, estadual e federal; } \\
\text { - } & \text { não ter assento em outro conselho municipal. }\end{array}$ \\
\hline & $\begin{array}{l}\text { um ano, sendo possível apenas uma reeleição consecutiva; } \\
\text { o cargo será declarado vago quando da renúncia ou perda do mandato do } \\
\text { conselheiro titular e na impossibilidade dos suplentes assumirem. Nesse caso, o } \\
\text { COP deverá providenciar eleição extraordinária. }\end{array}$ \\
\hline $\begin{array}{l}\text { (artigo } 11^{\circ} \text { do } \\
\text { Regimento }\end{array}$ & $\begin{array}{l}\text { apreciar, discutir e opinar sobre as diretrizes da política tributária e de arrecadação } \\
\text { do poder público municipal. } \\
\text { apreciar, emitir opinião e indicar alteração no todo ou em parte do conjunto de obras } \\
\text { e atividades constantes do planejamento de Governo e orçamento anual } \\
\text { apresentados pelo Executivo, em conformidade com o processo de discussão do } \\
\text { Orçamento Participativo; } \\
\text { acompanhar a execução orçamentária anual e fiscalizar o cumprimento do Plano de } \\
\text { Investimentos, opinando sobre eventuais incrementos, cortes de } \\
\text { despesas/investimentos ou alterações no planejamento; } \\
\text { opinar e decidir em comum acordo com o Executivo a metodologia adequada para o } \\
\text { processo de discussão e definição da peça orçamentária e do Plano de }\end{array}$ \\
\hline
\end{tabular}




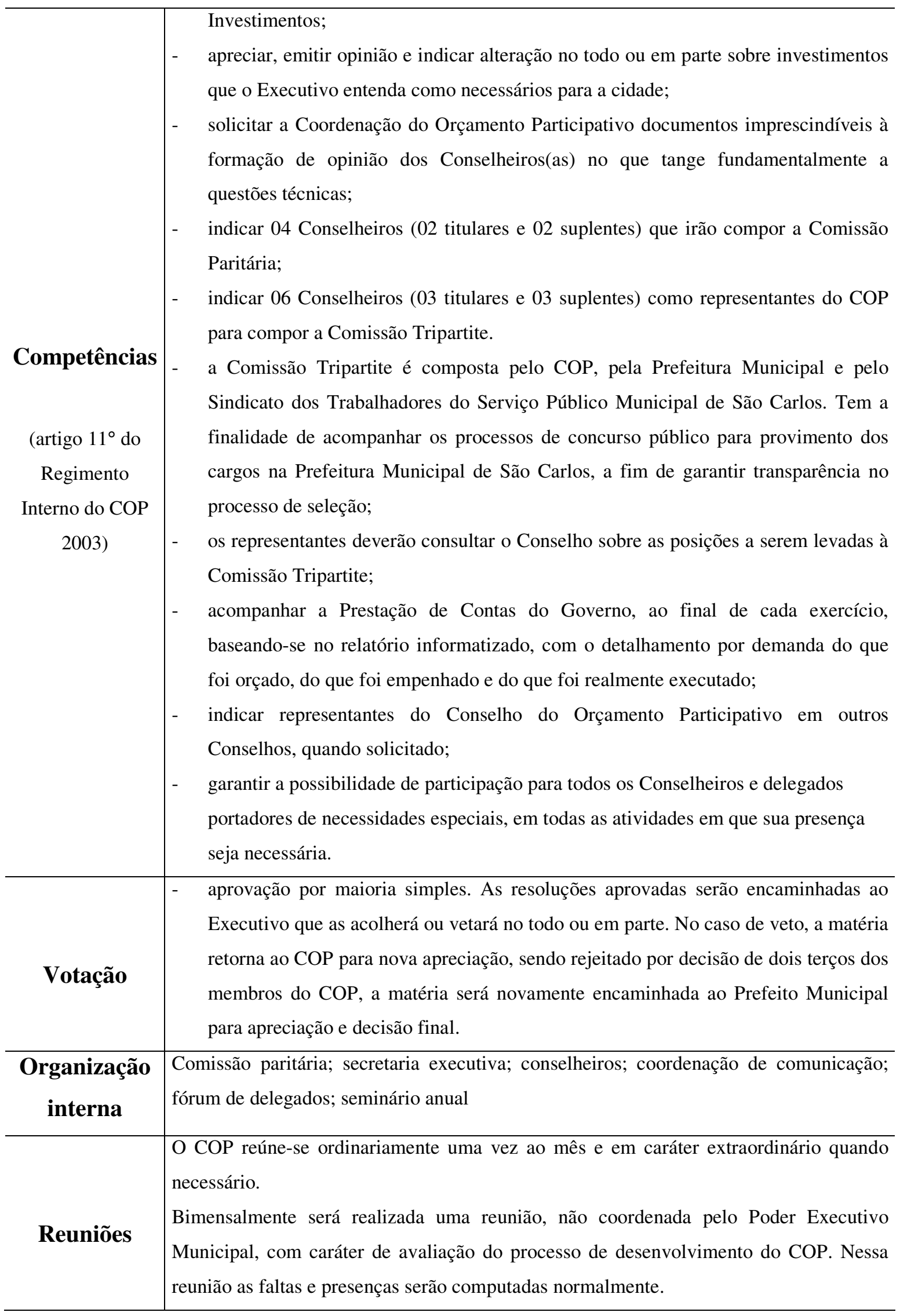




\begin{tabular}{l|l}
\hline & $\begin{array}{l}\text { As reuniões do Conselho são abertas, sendo permitida a livre manifestação dos titulares } \\
\text { e suplentes presentes sobre assuntos da pauta, respeitada a ordem de inscrição, que } \\
\text { deverá ser requerida à Coordenação dos Trabalhos. } \\
\text { O direito a voz poderá ser estendido aos demais presentes, através de votação específica } \\
\text { neuniões reunião em curso. } \\
\text { Nas reuniões terão direito a voto apenas os Conselheiros titulares ou suplentes no } \\
\text { exercício da titularidade. }\end{array}$ \\
\hline
\end{tabular}

\section{Comissão Paritária}

\begin{tabular}{|c|c|}
\hline Compc & $\begin{array}{l}\text { O Conselho Municipal do Orçamento Participativo será coordenado pela Comissão } \\
\text { Paritária. A Comissão Paritária será composta por } 4 \text { (quatro) membros do Poder } \\
\text { Executivo Municipal e } 4 \text { (quatro) Conselheiros do COP. }\end{array}$ \\
\hline $\begin{array}{l}\text { (Artigo } 18^{\circ} \text { do } \\
\text { Regimento } \\
\text { Interno do COP }\end{array}$ & 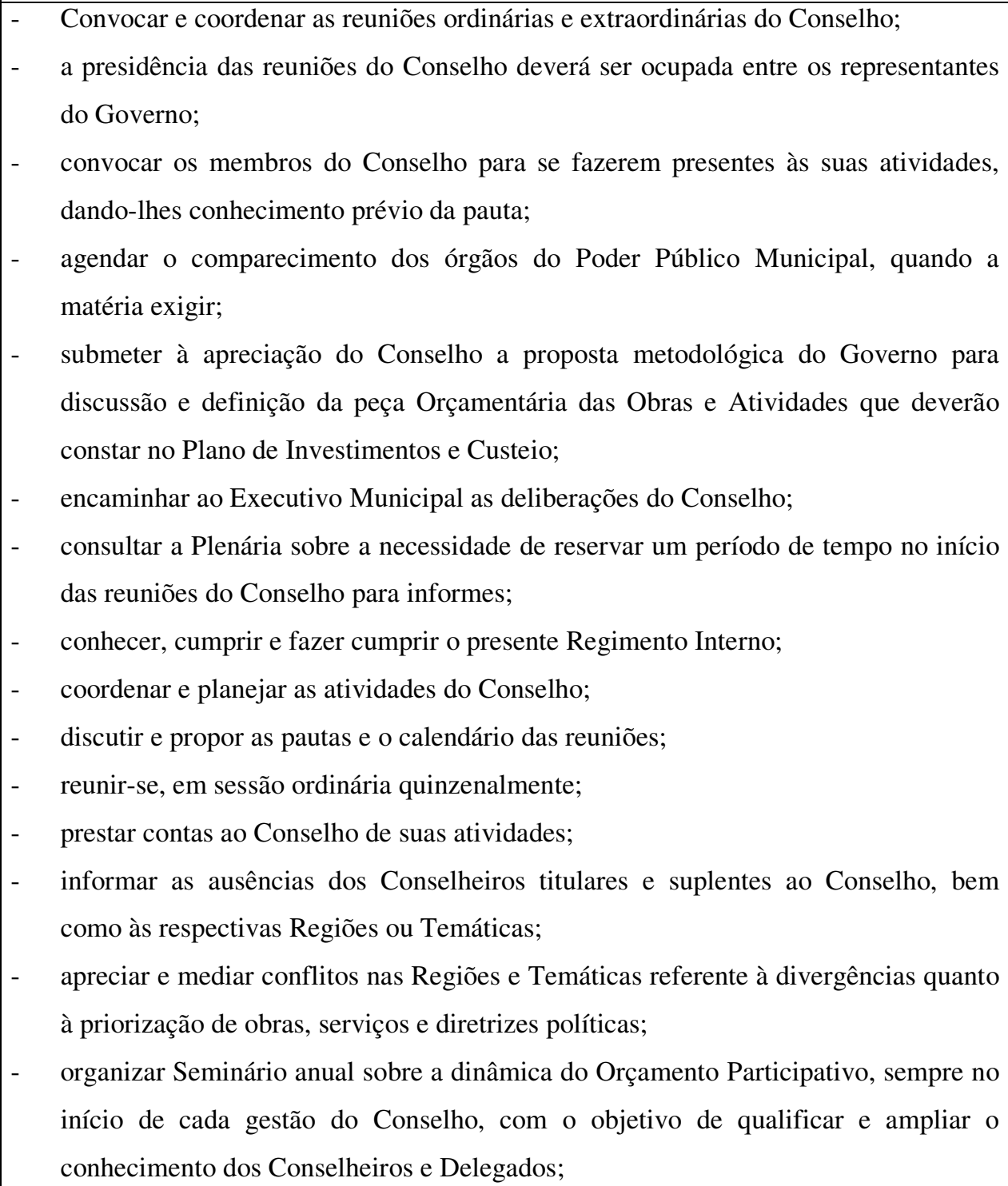 \\
\hline
\end{tabular}




\begin{tabular}{|c|c|}
\hline & $\begin{array}{l}\text { - discutir e apresentar propostas de solução para assuntos que envolvam duas ou mais } \\
\text { regiões. }\end{array}$ \\
\hline \multicolumn{2}{|r|}{ Secretaria Executiva } \\
\hline & A secretaria executiva será mantida pela Administração Municipal, através do COP. \\
\hline $\begin{array}{l}\text { (Artigo } 20^{\circ} \text { do } \\
\text { Regimento }\end{array}$ & 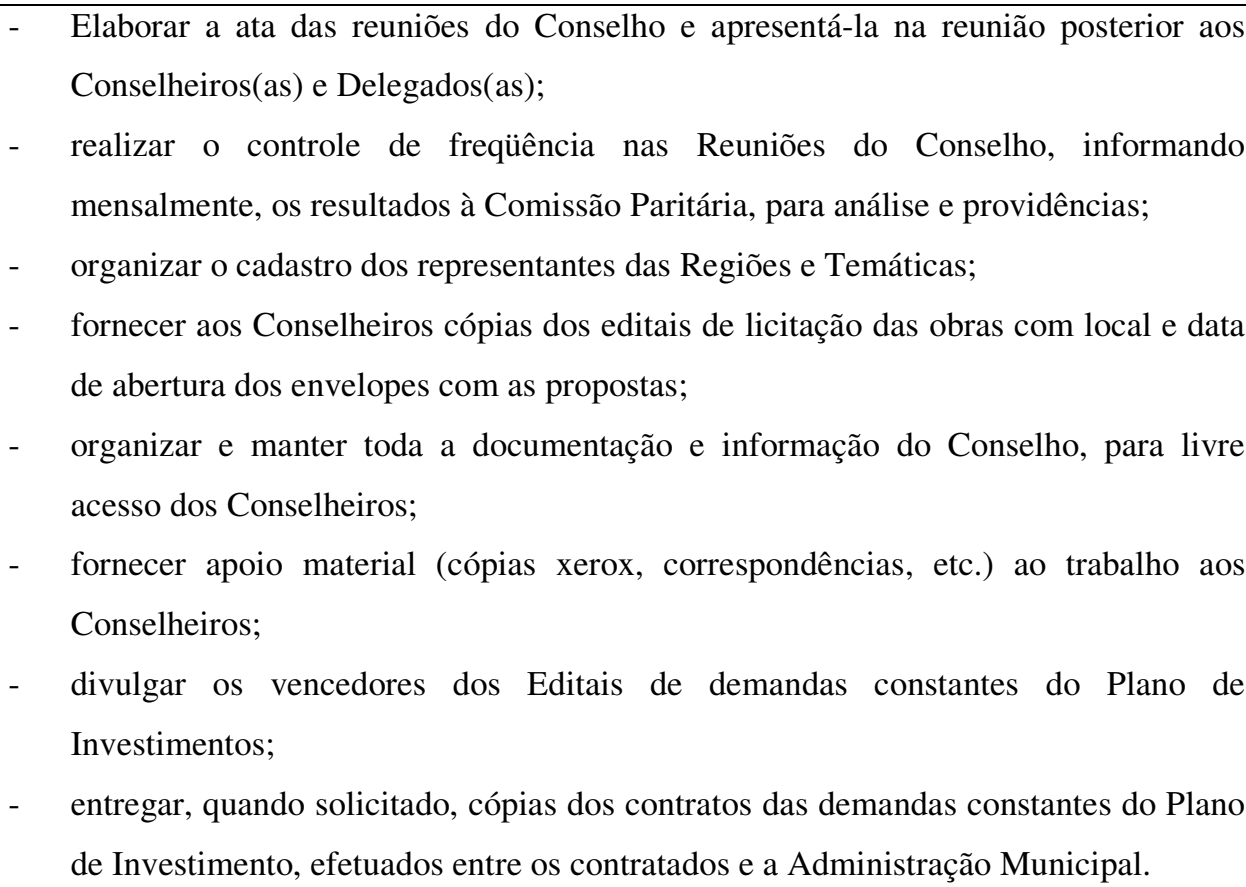 \\
\hline
\end{tabular}

\section{Conselheiros}

\begin{tabular}{|c|c|}
\hline $\begin{array}{c}\text { Direitos } \\
\text { (Artigo } 21^{\circ} \text { do } \\
\text { Regimento } \\
\text { Interno do COP } \\
2003)\end{array}$ & $\begin{array}{l}\text { Votar e ser votado em eleições de representação do Conselho; } \\
\text { participar com direito a voz e voto das Assembléias Gerais (Rodadas) e Reuniões da } \\
\text { sua Região ou Temáticas; } \\
\text { acompanhar o cumprimento das resoluções e decisões tomadas pelo Conselho. }\end{array}$ \\
\hline $\begin{array}{c}\text { Deveres } \\
\text { (Artigo } 22^{\circ} \text { do } \\
\text { Regimento } \\
\text { Interno do COP } \\
2003)\end{array}$ & 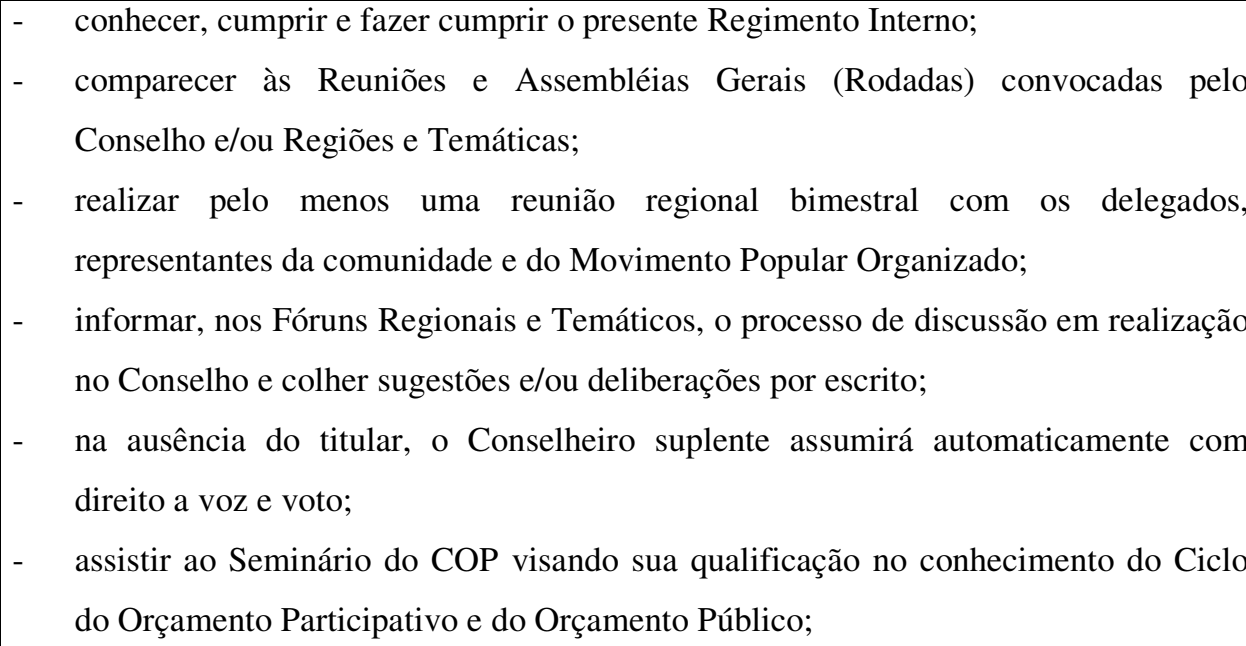 \\
\hline
\end{tabular}




\begin{tabular}{|c|c|}
\hline & $\begin{array}{l}\text { - os Conselheiros deverão disponibilizar ao público seus endereços e telefones para } \\
\text { facilitar a execução de suas funções. }\end{array}$ \\
\hline \multicolumn{2}{|r|}{ Comissão de Comunicação } \\
\hline Composição & $\begin{array}{l}\text { A Coordenação de Comunicação será composta por dois membros do Governo } \\
\text { Municipal (indicados pelo Executivo Municipal); e dois Conselheiros e } 2 \text { Delegados } \\
\text { eleitos na } 1^{\text {a }} \text {. Reunião de Trabalho do COP. }\end{array}$ \\
\hline $\begin{array}{l}\text { Atribuições } \\
\text { (Artigo } 28^{\circ} \text { do } \\
\text { Regimento } \\
\text { Interno do COP } \\
\text { 2003) }\end{array}$ & 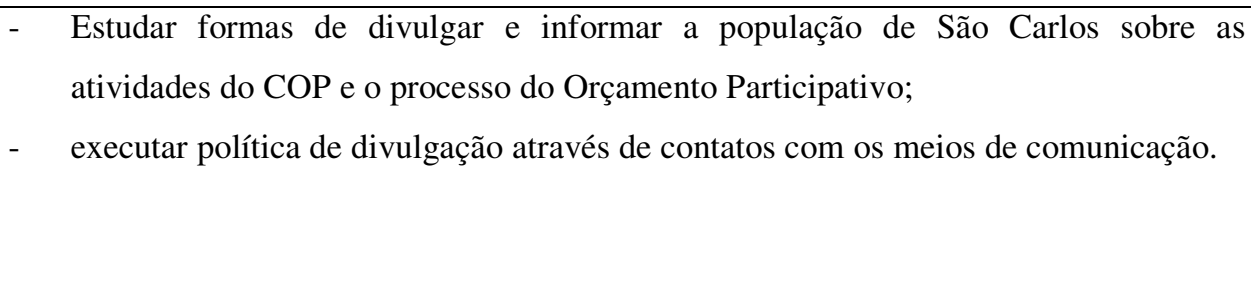 \\
\hline
\end{tabular}

\section{Delegados}

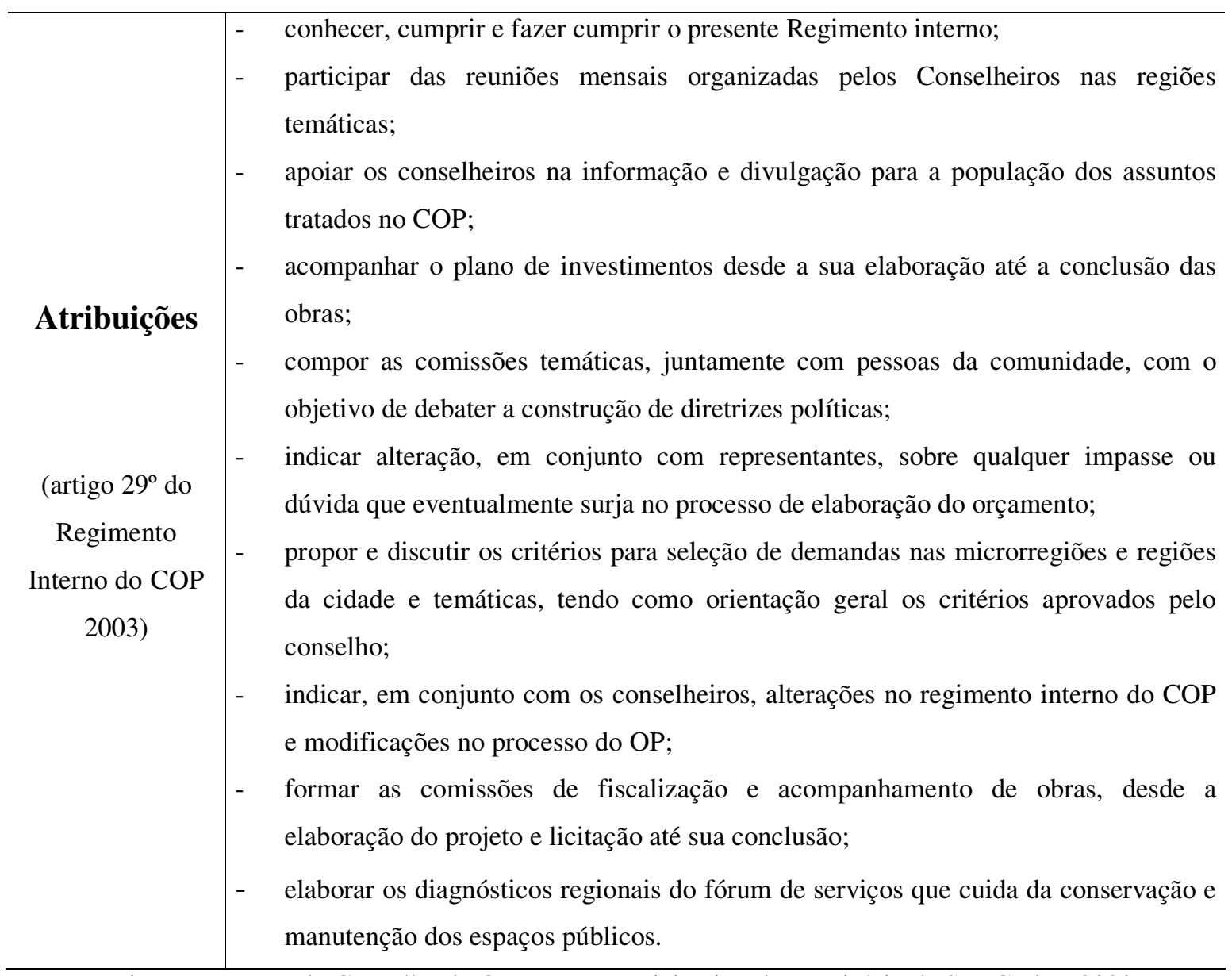

Fonte: Regimento Interno do Conselho do Orçamento Participativo do Município de São Carlos, 2003. 


\subsection{Metodologia}

Para a compreensão da dinâmica do Orçamento Participativo / São Carlos (OP/SC) e a análise da participação política da sociedade civil são-carlense nesse processo, principalmente, no que se refere às questões socioambientais, adotamos as abordagens qualitativa e quantitativa. Para tal nos apoiamos em procedimentos de investigação como a observação direta, interpretação de questionários respondidos por participantes do OP (conselheiros e delegados e seus suplentes), tabulação e análise das obras e serviços solicitados nas $1^{\mathrm{a}}$. Assembléias Regionais Gerais (fase informativa) durante os anos de 2001 a 2004.

Os dados foram coletados através de questionários, observação direta e tabulação das demandas das regiões por obras. Os questionários (entrevista estruturada) cumprem nesse sentido pelo menos duas funções: descrever as características e medir determinadas variáveis dos conselheiros e delegados (titulares e suplentes) participantes do OP/SC.

A forma escolhida de aplicação dos questionários foi através do envio pelo correio, pois permitiu incluir um grande número de pessoas e em pontos geográficos diferentes, apesar de apresentar algumas desvantagens, como a baixa taxa de devolução, normalmente não superior a $70 \%$ e o viés nas respostas dos questionários, pois, geralmente, os formulários são devolvidos pelas pessoas mais interessadas em colaborar. Mesmo conhecendo essa desvantagem, foi escolhida essa forma pelos seguintes fatores:

(1) o número de participantes (conselheiros, delegados e seus suplentes) é muito grande, cerca de 120 pessoas por gestão;

(2) uma grande parcela não comparece às reuniões da fase deliberativa, especialmente os suplentes;

(3) foi inviável a aplicação dos questionários durante as reuniões mensais, pois:

i. é o momento de encontro prévio para discussões sobre as deliberações daquele mês;

ii. pela impaciência das pessoas em responder a um questionário razoavelmente longo, em pé e com muitas pessoas no entorno;

iii. normalmente todos chegam ao mesmo tempo e já atrasados;

iv. o final da reunião acontece em hora adiantada; 
v. quando da tentativa de se aplicar o questionário nesse momento, a margem de respostas negativas foi muito elevada.

As formas de observação foram a não participante e a participante. A observação participante foi aplicada no primeiro ano, quando a pesquisadora participou como conselheira da plenária temática Desenvolvimento Sustentável e Meio Ambiente.

Dados secundários também foram utilizados como subsídio, tais como relatórios, atas, estatutos, legislações, artigos de jornais e revistas pertinentes ao tema e ao processo de OP. Por fim, utilizamos a técnica de triangulação, que possibilitou a constância e retroalimentação entre os dados analisados, em que buscamos a máxima amplitude na descrição, explicação e compreensão do foco de estudo. 


\section{Capítulo 4 - Resultados e Discussão}

Antes de partimos para a análise dos dados, salientamos alguns pontos importantes:

(1) os dados sobre as demandas solicitadas nas 1. a Assembléias Gerais Populares Regionais referentes aos anos de 2001 a 2004 e que geraram os Gráficos de 1 a 10, foram fornecidos pela Coordenação do OP;

(2) as obras requeridas podem ser, tanto para instalação e/ou construção como manutenção ou recuperação de instalações e/ou equipamentos antigos;

(3) para a análise das demandas, a pesquisadora não estabeleceu diferenças entre áreas de lazer, áreas verdes e praças, pois a linha que as diferencia é muito tênue e a tentativa de diferenciação poderia gerar distorções na análise.

Na sequiência, partimos para a análise da tabulação dos dados dos questionários

(Quadro 7) e, em seguida, para a análise dos dados obtidos através dos gráficos ) de 01 a 10) e mapas temáticos (de 12 a 52).

\subsection{Tabulação dos dados do questionário}

Ao iniciar a análise da tabulação dos dados dos questionários, não podemos deixar de citar o pequeno retorno de respostas, cerca de $25 \%$ apenas, aliado à queda de $6 \%$ da primeira para a segunda remessa. Desse fato consideramos que:

(a) pela observação direta percebemos que muitos participantes não se sentiram aptos a responder e/ou podem não ter achado importante responder; 
(b) somente responderam àqueles que são mais engajados politicamente, isto é, as lideranças dos bairros e/ou regiões.

A maioria dos participantes que respondeu ao questionário, cerca de $80 \%$, afirma conhecer as lideranças e os conflitos políticos existentes na cidade, o que demonstra conhecimento e interesse, dos que responderam ao questionário.

Sobre a questão do possível comprometimento partidário:

(a) dos 52 questionários respondidos, 46 participantes, ou seja, 88\%, responderam a essa questão;

(b) a maioria, 30 participantes, ou seja, 65\%, são simpatizantes ou filiados ao partido do atual governo, desses:

- $6 \%$ sentem-se inibidos, no momento, de criticar o processo;

- $63 \%$ entendem que ser simpatizante ou filiado ajuda a promover acertos;

- $56 \%$ entendem que ser simpatizante ou filiado ajuda a apontar erros;

(c) a minoria, 16 participantes, ou seja, 35\%, não são simpatizantes ou filiados ao partido do atual governo, desses:

- $94 \%$ entendem que ser simpatizante ou filiado a outro partido não impede de buscar acertos;

- $25 \%$ entendem que fica mais fácil apontar os erros.

Um dado importante verificado nessa questão é de que a maioria dos conselheiros e delegados que o responderam é formada por simpatizantes ou filiados ao partido do atual governo. Isso pode vir a configurar um processo de mascaramento de possíveis erros e a manipulação de informações; favorecimentos e atuação de grupos majoritários, ou a aprovação de programas, projetos e demandas de interesse partidário ou do poder público. Essa particularidade também pode levar a um esforço maior para que o processo se fortaleça, pois a credibilidade do governo municipal depende do sucesso de suas políticas públicas, onde o OP é considerado um dos mais importantes.

Outrossim, esse dado pode reafirmar o fato de que os citadinos participantes do $\mathrm{OP} / \mathrm{SC}$ pertencem a uma pequena parcela da sociedade local, que sempre esteve engajada em movimentos sociais, ou são lideranças políticas ou de associações de bairro. Essa particularidade acaba por perpetuar o apartamento de uma grande parcela dessa sociedade civil na administração pública e no processo decisório de gastos do orçamento municipal. 
No que diz respeito à eficácia do OP no processo de política local de gastos:

(a) para $61 \%$ é eficaz;

(b) para $12 \%$ não é eficaz;

(c) $27 \%$ não sabem dizer.

Consideramos o número de participantes que não sabe dizer se o OP é eficaz no processo de política local de gastos muito alto. Para sanar esse problema, entendemos como necessário um maior esclarecimento aos participantes sobre o assunto, talvez intensificando o número de palestras informativas.

De acordo com relatos dos participantes que não consideram o processo eficaz:

"Há pouca participação da população e os que participam não estão preparados para ver a importância da saúde, educação e meio ambiente nos anseios da comunidade” (Antonio, 52, 2002).

“O OP local ainda denota inúmeras falhas e distância total aos princípios da democracia participativa” (Sandra, 38, 2002).

Notamos que esses relatos aconteceram anteriormente às modificações implantadas na estrutura do OP/SC. Consideramos a importância de verificação de possíveis mudanças nesses relatos, entretanto, esses cidadãos não se reelegeram como conselheiros ou delegados o que impossibilitou essa análise.

A respeito da existência de manipulação e atuação de maiorias ou grupo no interior do OP.

Sobre a existência de manipulação:

(a) para $78 \%$ dos participantes ela não existe;

(b) para $22 \%$, existe manipulação.

Segundo os relatos dos participantes que percebem manipulação no processo:

“O percentual do orçamento do município destinado ao OP é pouco comparado ao que fica para a decisão do prefeito. Assim, o prefeito entra como salvador da pátria complementando as obras que mais dá dividendos políticos" (Antonio, 52).

"Acho necessária à conscientização dos participantes quanto a prioridade de eleger obras relacionadas a mais regiões da cidade" (Roselei, 28).

“A opinião que sempre prevalece é a do governamental” (Maria, 47).

“Todos (ou quase todos) os que participam são simpatizantes (não posso dizer militantes, pois a militância vai além das eleições) ou filiados ao partido do governo, o que para mim é uma manipulação governamental” (Robson, 18).

"A participação da sociedade traz benefício para o lugar, mas também a oportunidade de divulgar o partido e o prefeito" (José, 56). 
"Existe a manipulação na alocação de recursos e em algumas apresentações empolgantes" (Horaldo, 48).

Sobre a atuação de maiorias ou grupos:

(a) para $76 \%$ não existe essa atuação;

(b) para $24 \%$ existe uma maioria ou grupo atuando.

Alguns relatos dos participantes que consideram que existe a atuação de grupos ou maiorias:

"No meu modo de ver deveria se colocar menos pessoas ligadas ao partido do governo no OP. Que se procurasse mais pessoas ligadas a sociedade para se dar mais transparência a gestão" (André, 36).

“Do PT” (Antonio, 52).

"Porque têm alguns que opinam e votam em benefício próprio" (Joana, 47).

"Quando há participação maciça das pessoas de um bairro, geralmente as obras se concentram nele" (Luigi, 26).

"Na medida que o processo vai se concretizando a população vai se interessando pelo processo e os grupos se formam automaticamente" (Roselei, 28).

"A participação da aliança com o PMDB de Santa Eudoxia é uma volta ao passado da corrupção e do coronelismo existentes há mais de vinte anos no distrito" (José, 56).

"Se a maioria for de uma região, sim" (Pedro, 57).

“Alguns grupos de bairros com questões previamente definidas demonstrando desprezo por outras questões apresentadas" (Horaldo, 48).

Ao serem questionados se conseguem combater esse processo, tanto de manipulação quanto da atuação de grupos ou maiorias, os participantes responderam:

(a) para $61 \%$, é possível combater esse processo;

(b) para $39 \%$, não existe a possibilidade de combate.

Sobre se esse processo existir de fato pode ser um estímulo a continuar participando ou não, responderam:

(a) $70 \%$ continuam participando;

(b) $30 \%$ deixam de participar.

Perguntados, por fim, se são discriminados ou inferiorizados por outros participantes, apenas um dos participantes respondeu que sim.

Apesar da maioria dos participantes não sentirem, ou observarem manipulação e a atuação de maiorias ou grupos no interior do OP, a afirmação da existência desse processo, mesmo que por poucos participantes, tem um grande peso. Principalmente quando os discursos acadêmicos e partidários afirmam que o OP é um espaço que rompe com o antigo 
modelo de governar, onde a sociedade civil tem a possibilidade de quebrar a hegemonia de favorecimento de grupos e de interesses da própria administração pública.

Além disso, quando se leva em consideração de que a maioria dos participantes que respondeu ao questionário é de simpatizantes, ou filiados ao partido do governo a afirmação da inexistência de manipulação ou atuação de grupos ou maiorias pode estar mascarada ou equivocada. Pela observação direta, também notamos que no momento da fala, ou da argüição, os participantes mais ativos são dessas lideranças, isto é, a maioria simpatizante ou filiada ao partido do governo atual.

Quando a maioria dos participantes refere-se à manipulação, tem como foco os grupos formados nas regiões, isto é, maiorias formadas nas regiões a fim de concentrar a aprovação de obras de seu interesse, evidenciando o bairrismo e o individualismo de uma parcela dos participantes. Essa particularidade acaba gerando problemas para a aprovação de obras em algumas regiões e de grandes obras, ou seja, aquelas que abarcam a cidade como um todo.

Sobre a questão do combate a essa maioria, ou seja, formação de grupos, grande parcela dos conselheiros e delegados entende que é possível combatê-la e que isso não os desestimula a participar.

Sobre o tempo de participação no OP:

(a) $24 \%$ estão participando desde o início;

(b) $24 \%$ estão participando desde 2002;

(c) $2 \%$ estão participando desde 2003 ;

(d) $50 \%$ estão participando pela primeira vez.

Com esse dado, percebemos que novos participantes estão chegando ao OP/SC, o que pode comprovar um momento em que a sociedade civil local está se tornando mais participativa. Ou seja, está percebendo a existência desse espaço, a importância da participação e observando o retorno que pode estar acontecendo para o seu bairro em termos de resolução de seus problemas de infra-estrutura e, conseqüentemente, de melhoria de qualidade de vida.

Retomando a questão sobre a participação da sociedade civil são-carlense em espaços públicos, verificamos que, quando questionados se já haviam participado de conselhos, ou associações de bairros, os participantes responderam: 
(a) $42 \%$ já participaram ou participam desses espaços, sendo que $77 \%$ desses ocuparam ou ocupam cargo de liderança;

(c) $58 \%$ nunca haviam participado desse tipo de espaço.

Quando questionados do porquê participar do OP:

(a) dos 52 participantes que responderam ao questionário, 51 responderam a essa questão e todos assinalaram mais de uma resposta;

(b) $18 \%$ nunca haviam participado e tinham curiosidade;

(c) $37 \%$ consideram importante a participação nesses espaços;

(d) $25 \%$ eram participantes de associações de bairros e receberam indicação para serem delegados e/ou conselheiros;

(e) $63 \%$ participam porque desejam melhorias para seu bairro;

(f) $86 \%$ participam a fim de buscar melhorias, tanto para si quanto para a comunidade.

Notamos que a maioria dos participantes nunca havia participado de espaços públicos, mas a diferença para os que já participavam é muito pequena (16\%), isto é, existe um equilíbrio entre os que têm experiência nesse tipo de espaço e os "novatos". Uma significativa parcela dos participantes já tem essa experiência e cerca de $77 \%$ destes (quase a totalidade) exercem ou exerceram cargos de liderança, sendo a maioria de lideranças de esquerda, o que vem ao encontro da questão da majoritária participação de simpatizantes do atual partido do governo.

Outro dado que merece registro é de que $25 \%$ dos 51 participantes que responderam ao questionário foram indicados para serem delegados ou conselheiros. Por observação direta e por alguns relatos informais, verificamos que alguns receberam indicação de seus pares, por serem participantes de associação de bairros e/ou serem líderes em sua comunidade. Outros foram indicados, ou convidados pela Coordenação, em conseqüência do pouco interesse dos citadinos, ou seja, em algumas das regiões não existiam candidatos.

Sobre os resultados concretos da participação no OP, a grande maioria percebe que sua participação está dando frutos, isto é, suas expectativas e de sua comunidade estão sendo atendidas e/ou consideradas.

Seguem alguns relatos dos participantes:

“Acho que é dever de todo cidadão participar da administração” (Agostinho, 60). 
"Realização de grandes obras, só através do OP. Esta administração dá abertura sobre verbas a serem liberadas para votação” (Edílson, 56).

"Com o OP não há maneira de manipulação nem corrupção, pois quem diz o que fazer com o dinheiro é a população" (Izabel, 22).

“Acredito no processo e na transparência do OP com a cidade de São Carlos” (Jair, 37).

"Participo porque foi até agora o único governo que foi totalmente democrático" (José, 62).

"Saber para onde vai parte do dinheiro público com impostos que eu pago" (Joel, 38).

"É nosso direito criticar, mas nosso dever buscar a solução" (Luigi, 26).

"Acredito na participação da sociedade civil nas decisões, delineamento das políticas públicas, coordenados pelos membros da sociedade política” (Sandra, 38).

"É necessário saber onde é aplicado o orçamento" (Teruko, 33).

"É uma maneira de fazer valer o direito de ser cidadão" (Maria, 47).

"Éstá é uma ferramenta que viabiliza a participação, mesmo que restrita, em decisões importantes para a cidade" (Marco, 48).

"Quero ajudar no que puder os administradores de nossa cidade. Entendo ser nossa obrigação" (Roberto, 57).

"Quero uma cidade melhor para viver e um melhor amanhã para nossos filhos" (André, 37).

"Também quero fiscalizar para onde vai o dinheiro público, além de cobrar o que o povo votou" (Vanilde, 47).

"É uma oportunidade única, nunca vivida até então, de colaborarmos com a administração da cidade" (Edna, 48).

"Gosto da administração pública, é uma forma de estar "informado" e acredito que apenas com a participação insistente de poucos pode motivar a um crescimento do número de participantes, gerando uma maior fiscalização por parte da população sobre a coisa pública e um maior respeito dos administradores pelo OP” (Horaldo, 48).

Percebemos pelos relatos acima que esses participantes entendem a importância de sua efetiva participação no processo de co-gestão na implementação de políticas públicas. Mesmo sendo um processo que ainda têm falhas, compreendem a sua importância e acreditam que podem contribuir para a sua melhoria. Podemos comprovar essa afirmação, pois os mesmos participantes que, em outras questões, sinalizaram falhas, ou problemas, nesse momento relatam a significância política e educacional do OP/SC.

No que diz respeito a sentirem ou não resultados concretos de sua participação:

(a) dos 52 questionários enviados, 49 participantes responderam a essa questão;

(b) $71 \%$ sentem esses resultados;

(c) $29 \%$ não os sentem. 
De acordo com os participantes que não sentem resultados concretos em sua participação:

“Foi prometida e não cumprida até agora muitas coisas" (Ana Luiza, 42, 2002).

"Porque não estou vendo resultado nenhum no bairro, principalmente, asfalto nas ruas" (Edvaldo, $38,2002)$.

"As respostas são morosas, até agora de quatro solicitações não obtive resposta de nenhuma" (José, 67, 2002).

"De modo geral, as reivindicações ou solicitações enviadas aos diversos setores da administração pública ou ao coordenador do OP sequer logram ser respondidas, no entanto, ao indicar a necessidade de revisão e implementação do regimento interno, esta foi propiciada pela ação do secretário municipal de governo, membro hierarquicamente superior ao Coordenador do OP” (Sandra, 38, 2002).

"Obras foram aprovadas, mas não foram concluídas" (Thiago, 21, 2002).

“Porque não estou vendo ainda o prometido feito" (Jonas, 32, 2002).

"O maior problema está na falta de retorno sobre informações solicitadas. Bem informados possuem um potencial maior de colaboração" (Horaldo, 48, 2004).

Percebemos que a maioria das falas relatando a dificuldade em sentir resultados concretos foi no ano de 2002, antes das mudanças estruturais promovidas na deliberação das demandas. Para a confrontação se esses participantes sentiram diferença real com as mudanças seria necessária a sua reeleição, o que não ocorreu.

No que se refere à percepção ambiental dos participantes:

(a) $83 \%$ consideram que existem demandas ambientais em sua região;

(b) $17 \%$ não percebem nenhuma demanda ambiental em sua região.

O percentual de respostas, considerando a questão ambiental, aparentemente é alto, mas $67 \%$ de participantes deixaram de responder a essa pergunta. Esse fato deixa claro que mais da metade dos participantes que responderam ao questionário não têm a questão ambiental como uma das prioridades de sua região, ou não consegue enxergá-la em muitos dos problemas que sofrem. Por meio dos relatos a seguir, percebemos que os problemas mais referidos nas falas dos participantes são: (a) a questão da água, principalmente, no que diz respeito ao tratamento de esgoto e limpeza de córregos e rios; (b) a questão de áreas verdes, com o sentimento de ausência de espaços para lazer, contemplação e encontros.

Não percebem nenhuma questão ambiental em sua região:

“Não, porque abrange uma área rural” (José, 57). [se referindo a sua região, que é área rural]

“Não, esses problemas a prefeitura mesmo pode resolver” (Michella, 24).

“Não discutimos por este ângulo os problemas dos bairros" (Vanilde, 47). 


\section{Percebem alguma questão ambiental em sua região:}

”Tratamento de esgoto. Para diminuir a poluição dos rios" (Agostinho, 60).

“Enchentes. Não tem galerias pluviais” (Ana Luiza, 42).

“Emissário. Odor, proliferação de insetos e risco de doenças” (Edílson, 52).

“Tratamento de esgoto. Esgoto não é para ser jogado no rio” (José, 62).

“Tratamento de esgoto. Polui o rio” (Joel, 38).

“A implantação de praças, bem como áreas de lazer que inclua espaço verde, sendo localizada na área urbana, sendo bem planejada e utilizada de forma correta, podem contribuir além da questão de lazer, para a área ambiental também. A falta dessas áreas, além de causar os transtornos urbanos já bem declarados, como falta de espaço para lazer das crianças e adolescentes, falta de espaço de convivência etc., deixam de ser locais que poderiam ser aproveitados para o plantio de árvores e plantas nativas e de programas ambientais” (Karina, 24).

“Áreas de lazer / praças. Na minha região há o desmatamento de chácara para construção de residencial; falta de arborização no residencial e na praça” (Luigi, 26).

“Plantio de árvores, áreas verdes. Porque São Carlos possui poucas áreas verdes”. (Luiz, 40)

“Acerto das erosões, plantio de árvores. Com elas a melhoria do bairro será evidente”. (Milton, 55)

“Rede de esgoto. Não temos saneamento básico por não temos políticos sérios” (Rubens, 50).

“A falta de árvores nas vias públicas, boca de lobos cheias de garrafas pet e sacos de lixos e outras coisas mais" (Thiago, 21).

“Falta de galerias pluviais. Está assoreando o córrego do Itamaré, além das erosões causadas em época de chuvas" (Roselei, 28).

“Limpeza dos córregos. Evita a poluição do ambiente” (Maria, 47).

"Acontece a pulverização por parte das usinas de açúcar nas residências e no poço artesiano que abastece o distrito, além disso, área de preservação nos rios Mogi-Guaçu e Quilombo não está sendo respeitada - árvores nativas centenárias estão sendo abatidas, esgoto jogado nos rios” (José, 56).

“As erosões. Porque estão transformando o bairro em um enorme buraco” (Pedro,57).

“Combate a enchentes" (Anderson, 19).

“Áreas de lazer, praças. Melhor qualidade de vida” (Arlindo, 54).

“Todos, exceto o centro de saúde. Entendo a questão ambiental como ampla, abarcando a relação das pessoas com a natureza e elas próprias” (Marco, 48).

“Tratamento de esgoto. Está poluindo o rio” (Agostinho, 61).

“Tratamento de esgoto. Causa poluição das águas nos rios e principalmente nos lençóis freáticos” (André, 37).

“Implantação de praças. No meu bairro existem muitos lugares destinados para fazer praças e área de lazer, enquanto não são feitas as pessoas usam para jogar entulho e lixos, prejudicando o meio ambiente" (Ailton, 32). 
"Sim, acúmulo de lixo e entulho, água parada, quando chove este lixo é levado pela água para as ruas entupindo outras galerias e poluindo rios, a água que sobra causa mal cheiro e atrai bichos e insetos para o local" (Edna, 48).

"Arborização, a cidade como um todo sofre com este problema, soma-se a isso as queimadas urbanas e dos canaviais" (Horaldo, 48).

Sobre o conhecimento de outros espaços públicos, dos que responderam a essa pergunta:

(a) $50 \%$ conhecem ou ouviram falar de Comitê de Bacias Hidrográficas, entretanto, somente $35 \%$ desses realmente sabem o que é, o que decidem e quem pode participar e como;

(b) $50 \%$ conhecem ou ouviram falar do CONSEG e 58\% desses sabem o que é, o que decidem e quem pode participar e como;

(c) $33 \%$ conhecem ou ouviram falar do CONDEMA e somente $23 \%$ desses sabem o que é, o que decidem e quem pode participar e como.

A seguir reproduzimos alguns relatos espontâneos dos participantes sobre o OP:

"O ponto mais positivo do OP é que ele dá a oportunidade da população participar e expor seus anseios" (Antonio, 52).

"No bairro onde moro tem que haver uma conscientização prévia, quais os deveres para poder cobrar os direitos" (João, 55).

"De modo geral, o OP não funcionou segundo as diretrizes da democracia participativa, pois as informações não foram disponibilizadas em tempo hábil e necessário às reuniões nos bairros, especialmente: participação efetiva da população na tomada das decisões, ou seja, em geral, os conselheiros votam sem a consulta aos representantes, incidindo sobre a negação da democracia participativa” (Sandra, 38).

"Vejo o OP como um processo de aprendizado, assim estas manipulações tendem a diminuir com a evolução deste processo. Já as maiorias o problema está não nelas, mas sim nos ausentes. Não acredito que estas manipulações e maiorias sejam malignas, mas sim uma parte da evolução do processo de aprendizagem que trará uma reação futura levando a um equilíbrio de forças" (Horaldo, 48). 


\section{Quadro 7 - Tabulação dos dados dos questionários}

\begin{tabular}{l|r|r|r}
\hline & \multicolumn{1}{|c|}{$\mathbf{2 0 0 2}$} & \multicolumn{1}{c|}{$\mathbf{2 0 0 4}$} & \multicolumn{1}{c}{ Total } \\
\hline Questionários enviados & 120 & 120 & 240 \\
\hline Questionários respondidos & 32 & 21 & 53 \\
\hline
\end{tabular}

\section{Dados Pessoais}

\begin{tabular}{|c|c|c|c|c|c|c|}
\hline \multirow[t]{2}{*}{ Sexo } & M & $\mathbf{F}$ & $\mathbf{M}$ & $\mathbf{F}$ & $\mathbf{M}$ & $\mathbf{F}$ \\
\hline & 20 & 12 & 16 & 5 & 36 & 17 \\
\hline São-carlenses & & 7 & & 10 & & 17 \\
\hline \multicolumn{7}{|l|}{ Escolaridade } \\
\hline Ensino fundamental completo & & 6 & & 4 & & 10 \\
\hline Ensino fundamental incompleto & & 3 & & 1 & & 4 \\
\hline Ensino médio completo & & 12 & & 8 & & 20 \\
\hline Ensino médio incompleto & & 0 & & 0 & & 0 \\
\hline Ensino superior completo & & 4 & & 4 & & 8 \\
\hline Ensino superior incompleto & & 5 & & 1 & & 6 \\
\hline Mestrado & & 0 & & 2 & & 2 \\
\hline Doutorado & & 2 & & 1 & & 3 \\
\hline
\end{tabular}

Perfil dos participantes

\begin{tabular}{l|r|r|r}
\hline Conselheiros & 15 & 10 & 25 \\
\hline Delegados & 17 & 11 & 28 \\
\hline
\end{tabular}

Conhecem as lideranças e os conflitos políticos da cidade

\begin{tabular}{r|r|r|r} 
Sim & 23 & 20 & 43 \\
\hline Não & 7 & 1 & 8 \\
\hline
\end{tabular}

Comprometimento partidário

- ser simpatizante ou filiado ao partido do atual governo ajuda a promover mais acertos

- ser simpatizante ou filiado ao partido do atual governo ajuda a apontar possíveis erros que ocorrem no processo

- ser simpatizante ou filiado ao partido do atual governo inibe na hora de indicar possíveis erros

- $\quad$ ser simpatizante ou filiado a outro partido não impede na ajuda a promover mais acertos

- ser simpatizante ou filiado a outro partido fica mais fácil para apontar possíveis erros no processo

\begin{tabular}{r|r|r|r}
\hline & 10 & 9 & 19 \\
\hline & 8 & 9 & 17 \\
\hline & 2 & 0 & 2 \\
\hline & 10 & 5 & 15 \\
\hline & 2 & 2 & 4 \\
\hline
\end{tabular}




\begin{tabular}{rr|r|r|r}
\multicolumn{2}{l|}{ Consideram o OP eficaz no processo de política local de gastos } & \multicolumn{2}{|c|}{$\mathbf{2 0 0 2}$} & \multicolumn{2}{|c}{ Total } \\
\hline Sim & 19 & 12 & 31 \\
\hline Não & 2 & 4 & 6 \\
\hline Não sabe dizer & 9 & 4 & 13 \\
\hline
\end{tabular}

Percebem algum tipo de manipulação no processo

\begin{tabular}{rr|r|r|r}
\hline Sim & 6 & 5 & 11 \\
\hline Não & 22 & 14 & 36 \\
\hline
\end{tabular}

Percebem a atuação de maiorias ou grupos no processo

\begin{tabular}{rr|r|r|r}
\hline Sim & 6 & 6 & 12 \\
\hline Não & 21 & 14 & 35 \\
\hline
\end{tabular}

Conseguem combater a manipulação e/ ou a atuação de maiorias?

\begin{tabular}{r|r|r|r} 
Sim & 12 & 7 & 19 \\
\hline Não & 6 & 7 & 13
\end{tabular}

Essa manipulação e/ou atuação de maiorias é um estímulo a continuar participando do processo?

\begin{tabular}{rr|r|r|r}
\hline Sim & 11 & 14 & 25 \\
\hline Não & 8 & 2 & 10 \\
\hline Sentem-se inferiorizados ou discriminados por outros participantes & Sim & & 1 & 1 \\
\hline Não & 29 & 18 & 47 \\
\hline Tempo de participação & 10 & 3 & 13 \\
\hline Desde o início (2001) & 6 & 6 & 12 \\
\hline Desde 2002 & & 1 & 1 \\
\hline Desde 2003 & 15 & 10 & 25 \\
\hline
\end{tabular}

Como tomou conhecimento do OP

\begin{tabular}{r|r|r|r} 
Pelos meios de comunicação (rádio, TV, jornais) & 16 & 11 & 27 \\
\hline Pela comunidade de bairro & 15 & 9 & 24 \\
\hline Na conversa com amigos & 20 & 10 & 30 \\
\hline
\end{tabular}

Participação de outros espaços públicos (conselhos e/ou associações de bairros)

\begin{tabular}{rr|r|r|r}
\hline Sim & 12 & 10 & 22 \\
\hline Não & 20 & 11 & 31 \\
\hline
\end{tabular}

- Exerciam cargo e/ou liderança

\begin{tabular}{r|r|r|r} 
Sim & 7 & 10 & 17 \\
\hline Não & 4 & 1 & 5
\end{tabular}




\section{Porque participam do OP}

- Nunca haviam participado de outros espaços públicos e queriam saber como é participar.

- Acham muito importante a participação em espaços públicos.

- Participam de associações de bairros e recebeu indicação para ser delegado.

- Participam porque querem buscar melhorias para o bairro.

- Participam porque querem tornar a cidade melhor para si e para a comunidade.

Percebem resultados positivos concretos em sua participação

\begin{tabular}{r|r|r}
\multicolumn{1}{l|}{2002} & \multicolumn{2}{|c|}{ Total } \\
\hline 7 & 2 & 9 \\
\hline 12 & 8 & 20 \\
\hline 6 & 7 & 13 \\
& & \\
\hline 19 & 13 & 32 \\
\hline 26 & 19 & 45 \\
& & \\
\hline
\end{tabular}

\begin{tabular}{rr|r|r|r}
\hline Sim & 18 & 18 & 36 \\
\hline & Não & 11 & 3 & 14 \\
\hline
\end{tabular}

\section{Percepção ambiental}

Consideram algumas das demandas solicitadas pela sua região como sendo ambiental

\begin{tabular}{rr|r|r|r}
\hline Sim & 17 & 13 & 30 \\
\hline & Não & 5 & 1 & 6 \\
\hline
\end{tabular}

\section{Conhecimento de outros espaços públicos}

Conhecem ou ouviram falar em Comitê de Bacias Hidrográficas

\begin{tabular}{rr|r|r|r}
\hline Sim & 13 & 14 & 27 \\
\hline Não & 14 & 7 & 21 \\
\hline Sabem o que é, o que decidem, quem participa e como participar & 4 & 5 & 9 \\
\hline
\end{tabular}

Conhecem ou ouviram falar em CONSEG

\begin{tabular}{|c|c|c|c|}
\hline Sim & 12 & 15 & 27 \\
\hline Não & 15 & 6 & 21 \\
\hline Sabem o que é, o que decidem, quem participa e como participar & 7 & 9 & 16 \\
\hline
\end{tabular}

Conhecem ou ouviram falar em CONDEMA

\begin{tabular}{rr|r|r|r}
\hline Sim & 11 & 7 & 18 \\
\hline Não & 16 & 14 & 30 \\
\hline Sabem o que é, o que decidem, quem participa e como participar & 1 & 3 & 4 \\
\hline
\end{tabular}

Por fim, é importante entender como a Coordenação do OP/SC está analisando a institucionalização desse espaço no município e de como esse processo está sendo apropriado pela sociedade civil local. Assim, transcrevemos a entrevista concedida à pesquisadora pelo Coordenador do OP/SC, o Sr. Rosoé F. Donato, que tece sua percepção e faz um balanço de como esse espaço evoluiu durante os anos de 2001 a 2004. 
Para o Coordenador do OP um dos fatores mais importantes no processo do OP/SC nesses quatro anos foi a modificação na forma de deliberação de demandas, trazendo para esse espaço mais transparência e agilidade. Outro ponto importante destacado pelo Sr. Rosoé é a porcentagem do orçamento municipal destinado ao OP/SC, cerca de 95\% do total. Além disso, segundo ele, a institucionalização desse espaço em São Carlos tem fomentado a criação de associações de bairros, que saltou de 20 para 40 ao longo desses quatro anos. Concluímos, assim que, para a Coordenação do OP, esse espaço está em vias de crescimento e consolidação na sociedade civil são-carlense.

"Primeiramente, o OP é um processo. No primeiro momento nós elaboramos um projeto que veio sendo modificado ano a ano. Essa modificação não se dá porque o projeto inicial era errado, porque na verdade você tem um amadurecimento da participação. Você também tem, como se trabalha com a eleição e atendimento de demandas, mudanças nas características de demandas, então dessa forma você vai tendo que modificar. Agora, na experiência desses quatro anos eu acho que o mais importante em qualquer projeto de participação popular, não só $O P$, é que tem que ser um processo muito didático. Seja qual for a participação, seja qual for o público, porque não existe participação sem informação. Se você faz um processo que tem muitas regras, é muito complexo entender, mesmo que seja socialmente mais justo, vai faltar compreensão.

Se nós pegarmos em 2001, nós tínhamos um modelo muito mais justo do que o aplicado atualmente. Só que em termos didáticos ele era muito mais complicado. Então vale a pena, no meu entender, você até sacrificar um pouco a questão da justiça social, em prol de um processo no qual a população saiba exatamente o que está acontecendo. Ele era um modelo de pontuação, que levava em conta a população, a carência da região e uma série de questões para se chegar na obra que seria feita. Mas a população não tinha clareza e, dificilmente, terá clareza de todas essas contas, de toda essa matemática, que acaba dando uma nota. Embora isso nunca tenha ocorrido, dá a sensação de manobra, porque poucas pessoas entendem a conta, meia dúzia de pessoas põe um ponto aqui, outro acolá e ninguém sabe se está certo. Hoje nós chegamos a um processo limpo, altamente democrático e altamente didático. E permitiu que nós chegássemos nessa segunda gestão, num amadurecimento que nós nos propúnhamos a fazer.

O balanço positivo, eu acho que o melhor de tudo, é que São Carlos, infelizmente como uma das poucas exceções, conseguiu desenvolver democracia direta. O nosso modelo faz com que a população, e é a questão da didática, elejam as obras diretamente na região. Em outros modelos que nós conhecemos, acabase elegendo conselheiros que vão eleger obras, acaba sendo intermediação e nesse sentido nosso OP foi muito positivo. Nós conseguimos quebrar as intermediações, seja por lideranças políticas regionais, seja por lideranças a partir da casa legislativa e fazer com que o povo pudesse decidir de forma realmente direta e isso é um avanço inegável e importante.

Na primeira assembléia se coloca as questões e na segunda se vota. Nos estudos que são feitos em outras cidades como funciona: a população elenca as prioridades, só que quem acaba decidindo é o conselho. O que acontece, você acaba tendo uma mesa de negociações entre conselheiros e representantes do 
executivo. E os conselhos são formados, normalmente, com uma parcela razoável de representantes governamentais, nas outras cidades. E em São Carlos não, o conselho é 100\% população, mais 4 pessoas indicadas (2 titulares e 2 suplentes), pelo executivo, que são mediadoras. Para você ter uma idéia de como são os mediadores, no ano passado nós tínhamos uma pessoa indicada, não precisou a indicação de uma segunda, porque ele não tinha um papel no sentido de tomar decisão.

Esse é o maior ganho que nós conseguimos no nosso projeto na cidade de São Carlos, em desenvolver uma democracia onde a pessoa saia da reunião sabendo quais obras serão feitas e quais obras não serão feitas.

E porque houve esse amadurecimento? Porque nós notamos através do próprio conselho, mesmo sendo eleição direta, mas usando qualquer critério intermediário como pontuação às pessoas tinham uma dificuldade muito grande em acompanhar a posterior o que realmente tinha sido feito, o que realmente entrou no orçamento municipal e o que não entrou. E nós percebemos essas dificuldades no próprio conselho que tem um contato muito maior com a coordenação. Quer dizer, se os próprios conselheiros que se reúnem a cada 15 dias por mês, não conseguiram entender o processo, está errado. Por mais que ele seja bonito, por mais que ele seja perfeito, no sentido de justiça social e assim por diante, está errado, porque você não faz democracia quando você não tem um processo claro de informação, de conhecimento das regras do jogo. Sabemos que a maior ditadura que pode existir é a ditadura da informação e é isso que nós temos tentado quebrar.

Em 2002 entrou o critério de coincidência de obras, porque o processo de pontuação que nós tínhamos não permitia grandes obras, ele permitia obras do ponto de vista regional, posto de saúde, escolas. Mas se você tivesse que fazer grandes, obras envolvendo mais de uma região, havia uma dificuldade de critérios. Então nós incluímos o critério de coincidência. Que seria o que: nós tivemos além das reuniões regionais, reuniões temáticas. A cidade é dividida em quatro temas: Saúde e Cidadania; Educação, Esporte e Lazer; Desenvolvimento urbano; Desenvolvimento Sustentável e Meio Ambiente. A diferença é que em 2001 as reuniões temáticas foram só informativas, não teve decisão tomada. As pessoas participavam, colocavam seus anseios, servia de critérios internos para a prefeitura, mas não se chegava a eleger prioridades, obras.

Em 2002 tivemos duas reuniões: uma informativa e uma deliberativa onde se elegeu 4 prioridades em cada temática. E essas prioridades foram enviadas a todas as reuniões das regiões. Assim, além das obras regionais que os participantes tinham colocado no rol da informativa, eles tinham a opção de colocar essa obra da cidade entre as suas prioridades.

Mas a mudança mesmo no sentido de tirar a pontuação aconteceu no ano de 2003. E daí nós começamos a trabalhar num outro critério que era distribuição de recursos por região, de acordo com a população. E a partir daí a população tinha, por exemplo, $R \$ 300.000$ mil, elencava numa primeira reunião as obras necessárias. Na segunda reunião os participantes sabiam quanto tinham, quanto custava cada obra e ia votando nas obras e o dinheiro ia sendo deduzido. Então é um processo muito mais cotidiano, do que você usar métodos muito mais aprimorados.

Se pegarmos esse exercício e colocar no mapa as decisões tomadas pela população nós vamos perceber claramente, que sem interferência, sem influência, sem manipulação, a população conseguiu ter 
escolhas muito sábias. Se hoje nós temos uma qualidade de vida melhor em São Carlos, isso se deve muito à participação popular. Para além da capacidade técnica das pessoas da prefeitura, que é reconhecida, para além de tudo isso, o planejamento tem sido feito com muita participação. Esse fato mostra o quanto às vezes você subestima a capacidade popular, isso não pode ser feito. Com a participação popular hoje nós conseguimos ter uma rede de saúde, na distribuição geográfica, muito mais funcional. Em termos de creche conseguimos atender $100 \%$ da demanda. Conseguimos pavimentar quase a cidade inteira. Conseguimos resolver problemas como enchentes, praças. E o que a gente nota claramente é o reconhecimento do que vem acontecendo na co-responsabilidade no que não é feito. Trabalhamos no sentido de que cada vez que aparece uma demanda para a prefeitura, cada vez que há uma reclamação, explicar como funciona o OP e pedir às pessoas que se organizem e que participem. Deixando claro que essas decisões não competem mais ao prefeito e sua equipe e sim a decisão popular, é ela que tem de uma forma participativa, ditando os rumos dos investimentos em São Carlos.

[sobre a porcentagem do orçamento municipal no OP] Se em 2001 nós aplicamos em torno de $30 \%$ a $40 \%$ do orçamento, hoje nós estamos chegando a $90 \%$ da capacidade de investimento. Esse ano de 2004 para 2005 nós discutimos um montante na ordem de $R \$ 15$ milhões, no primeiro ano foram $R \$ 3.600$ milhões. Nós temos aí um crescimento na ordem de $400 \%$ na verba discutida. De certa forma, preferimos não vincular, se fizéssemos como as outras cidades, $2 \%$, 3\% do orçamento, não estaríamos como hoje, investindo aí cerca de 95 do orçamento total, em OP. As outras preocupações que as outras cidades tem, de passar uma lei na câmara, de regulamentar, de fazer isso institucional, nós não temos essa preocupação, porque até então não foi necessário. Nunca houve qualquer conflito no sentido de dinheiro, sempre o executivo acabou colocando mais dinheiro que os conselheiros esperavam, nas decisões populares.

Na verdade, eu acho que o OP tem estimulado as pessoas a gostar de política. Essa é a questão, ele acaba provocando um envolvimento das pessoas no que é público. Eu acho que essa forma participativa de governar, não só o OP, mas todos os outros conselhos, trazem na população de novo o gosto pelo que é público. Eu vejo algumas discussões de pessoas, senhores, que não tem nenhuma vinculação partidária, a forma como eles começam a discutir política nas reuniões do OP, políticas públicas e não política partidária, porque jamais discute isso em reuniões, mas é muito interessante esse envolvimento. As pessoas poderem colocar as suas idéias livremente, debater com o secretário, com o prefeito, com a equipe técnica. Eu acho que aonde o OP funcionar de verdade, vai ter uma maior mobilização das pessoas, no sentido do fortalecimento do gosto pela política pública na população. O OP aqui de São Carlos, assumiu com 20 associações de bairro e estamos com quase 40 associações, não houve o refluxo que normalmente a imprensa diz que há. Ou seja, as associações perdem o papel e somem, não, várias pessoas acabaram criando associações porque viram que era mais importante, para ter mais força nas mobilizações, para conseguir melhor atendimento nas suas demandas.” 
Quadro 8 - Ocupação e Perfil Socioeconômico das Regiões do OP, Município de São Carlos, SP

\begin{tabular}{|c|c|c|c|c|c|c|c|}
\hline $\mathbf{R}$ & Área & Ocupação e Expansão & 200 & & 200 & & Perfil socioeconômico da \\
\hline & & & Pop. & $\%$ & Pop. & $\%$ & \\
\hline 1 & Leste & $\begin{array}{l}\text { Ocupação: a partir de 1940; } \\
\text { última expansão: década de } \\
1980 .\end{array}$ & 23.592 & 12,0 & 25.290 & 12,1 & $\begin{array}{l}\text { Homogêneo, em sua } \\
\text { maioria residências de } \\
\text { padrão médio a alto. }\end{array}$ \\
\hline 2 & Sul & $\begin{array}{l}\text { Ocupação: entre } 1970 \text { e 1980; } \\
\text { áreas de expansão recente. }\end{array}$ & 14.352 & 7,3 & 15.466 & 7,4 & $\begin{array}{l}\text { Região de periferia; bairros } \\
\text { mais carentes de infra- } \\
\text { estrutura urbana. }\end{array}$ \\
\hline 3 & Noroeste & $\begin{array}{l}\text { Ocupação: a partir de 1960; } \\
\text { áreas de expansão recente. }\end{array}$ & 19.267 & 9,8 & 21.318 & 10,2 & $\begin{array}{l}\text { Heterogêneo, com } \\
\text { expansão periférica; possui } \\
\text { residências de alto e médio } \\
\text { a baixo padrão. }\end{array}$ \\
\hline 4 & Central & $\begin{array}{l}\text { Ocupação: núcleo urbano; } \\
\text { última expansão em } 1940 .\end{array}$ & 15,925 & 8,1 & 17,138 & 8,2 & $\begin{array}{l}\text { Região central; } \\
\text { caracterizado pelo centro } \\
\text { comercial. }\end{array}$ \\
\hline 5 & Norte & $\begin{array}{l}\text { Ocupação entre } 1950 \text { e } 1960 \text {; } \\
\text { última expansão entre } 1960 \text { e } \\
1970 .\end{array}$ & 21,626 & 11,0 & 23,618 & 11,3 & $\begin{array}{l}\text { Homogêneo; em sua } \\
\text { maioria residências de } \\
\text { padrão médio. }\end{array}$ \\
\hline 6 & $\begin{array}{c}\text { Santa } \\
\text { Eudoxia }\end{array}$ & $\begin{array}{l}\text { Ocupação: remonta a época } \\
\text { da fundação de São Carlos. }\end{array}$ & 1,572 & 0,8 & 1,572 & 0,8 & $\begin{array}{l}\text { Distrito do município; } \\
\text { basicamente de economia } \\
\text { rural. }\end{array}$ \\
\hline 7 & Sudeste & $\begin{array}{l}\text { Ocupação: } 1940 ; \quad \text { última } \\
\text { expansão: entre } 1970 \text { e } 1980\end{array}$ & 9,437 & 4,8 & 10,241 & 4,9 & $\begin{array}{l}\text { Homogêneo, em sua } \\
\text { maioria residências de } \\
\text { padrão médio. }\end{array}$ \\
\hline 8 & $\begin{array}{l}\text { Centro- } \\
\text { oeste }\end{array}$ & $\begin{array}{l}\text { Ocupação: 1940; expansão } \\
\text { entre } 1960 \text { e 1970; com áreas } \\
\text { de ocupação recente. }\end{array}$ & 10,813 & 5,5 & 11,495 & 5,5 & $\begin{array}{l}\text { Homogêneo, em sua } \\
\text { maioria residência de alto } \\
\text { padrão, entretanto, possui } \\
\text { bairros periféricos, mais } \\
\text { carentes de infra-estrutura. }\end{array}$ \\
\hline 9 & Sul & $\begin{array}{l}\text { Ocupação: 1940; expansão } \\
\text { entre } 1960 \text { e 1970; com áreas } \\
\text { de ocupação recente. }\end{array}$ & 33,619 & 17,1 & 36,158 & 17,3 & $\begin{array}{l}\text { Homogêneo, em sua } \\
\text { maioria residências de } \\
\text { médio padrão. }\end{array}$ \\
\hline 10 & $\begin{array}{c}\text { Água } \\
\text { Vermelha }\end{array}$ & $\begin{array}{l}\text { Área com expansão recente de } \\
\text { chácaras de recreio e } \\
\text { residência. }\end{array}$ & 589 & 0,3 & 1,572 & 0,8 & $\begin{array}{l}\text { Distrito do município; } \\
\text { basicamente de economia } \\
\text { rural; área de condomínios } \\
\text { de chácaras. }\end{array}$ \\
\hline 11 & Norte & $\begin{array}{l}\text { Ocupação: 1950; expansão } \\
\text { entre } 1950 \text { e 1960; com áreas } \\
\text { de expansão recente. }\end{array}$ & 19,070 & 9,7 & 20,482 & 9,8 & $\begin{array}{l}\text { Heterogêneo; com } \\
\text { residências de alto e médio } \\
\text { padrão. }\end{array}$ \\
\hline 12 & Norte & $\begin{array}{l}\text { Ocupação: } 1970 \text { e 1980; com } \\
\text { áreas de expansão recente. }\end{array}$ & 8,650 & 4,4 & 9,196 & 4,4 & $\begin{array}{l}\text { Homogêneo; em sua } \\
\text { maioria residências de } \\
\text { padrão médio a baixo. }\end{array}$ \\
\hline 13 & Sul & $\begin{array}{l}\text { Ocupação: } 1950 ; \quad \text { última } \\
\text { expansão: entre } 1960 \text { e } 1980 .\end{array}$ & 15,728 & 8,0 & 16,929 & 8,1 & $\begin{array}{l}\text { Homogêneo; em sua } \\
\text { maioria residências de } \\
\text { padrão médio a baixo. }\end{array}$ \\
\hline
\end{tabular}




\subsection{Tabulação dos dados das demandas}

No ano de 2001, verificamos a supremacia das demandas por galerias pluviais com $40 \%$ um item de infra-estrutura urbana estreitamente ligado à questão das enchentes (com $3 \%$ das demandas); por praças com $23 \%$ e por áreas de lazer com 15\%. (Gráfico 1). Essas solicitações constatam que a cidade ainda tem um déficit desses itens, ou falta de manutenção dos existentes por conta do modelo de urbanização adotado pelo município, caracterizado pelo crescimento rápido, desordenado e deletério. É mister ressaltar que isso ocorre e independe de fatores geográficos e/ou sócio-econômicos (Quadro 8), isto é, os bairros periféricos, em expansão, ou recentes carecem da instalação desses mesmos itens e os centrais e/ou antigos de manutenção, ou ampliação destes.

$\mathrm{Na}$ confrontação entre os Gráficos 1 e 2 (Quadro 9), constatamos que as demandas por obras verdes são menores que por outras obras como asfalto, iluminação pública, postos de saúde, creches etc., embora com uma importante relevância se observada em termos quantitativos.

Gráfico 1 - Total de Demandas Verdes / 2001

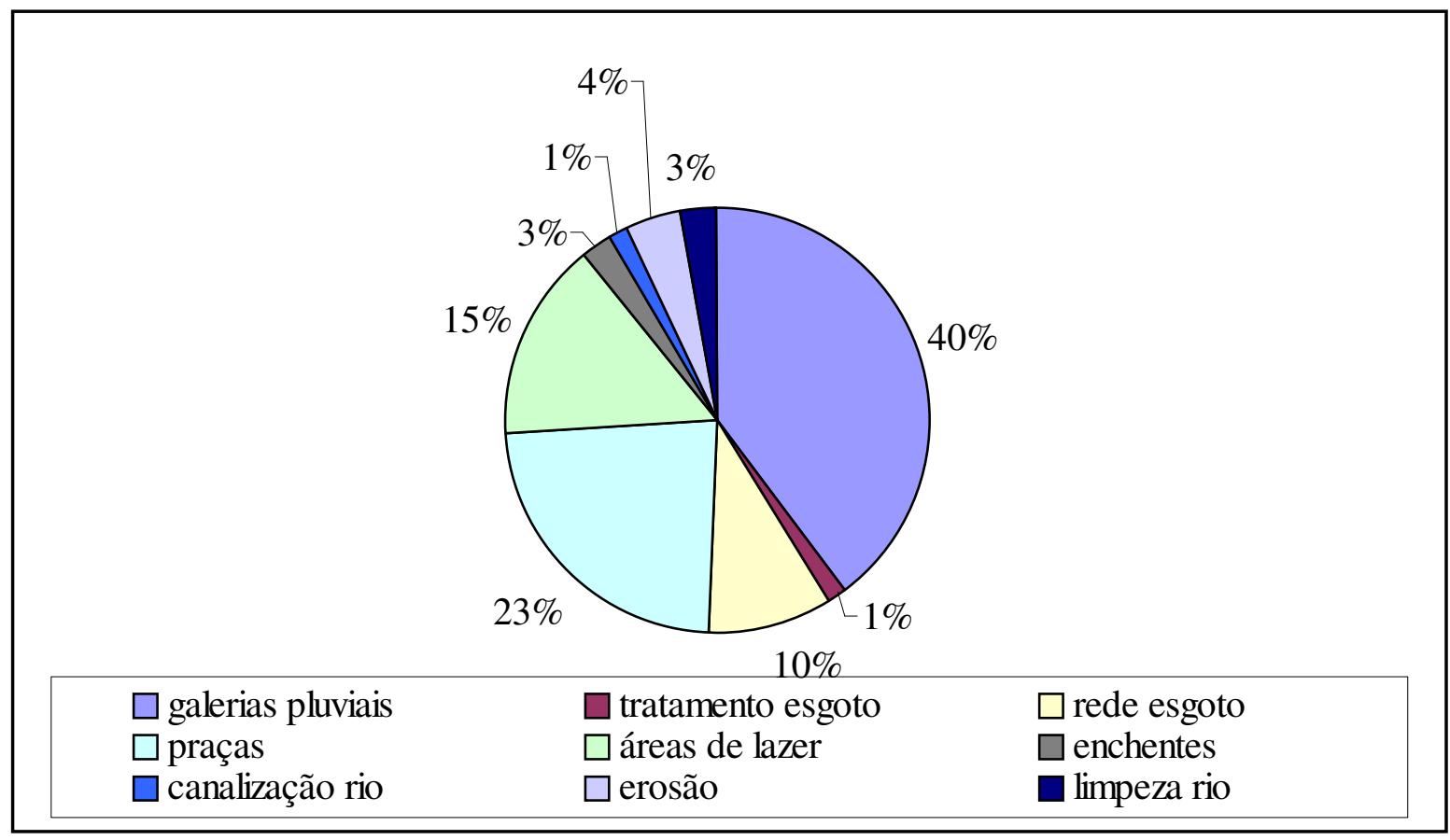


Gráfico 2 - Confronto por Região entre Demandas Verdes e as Demais / 2001

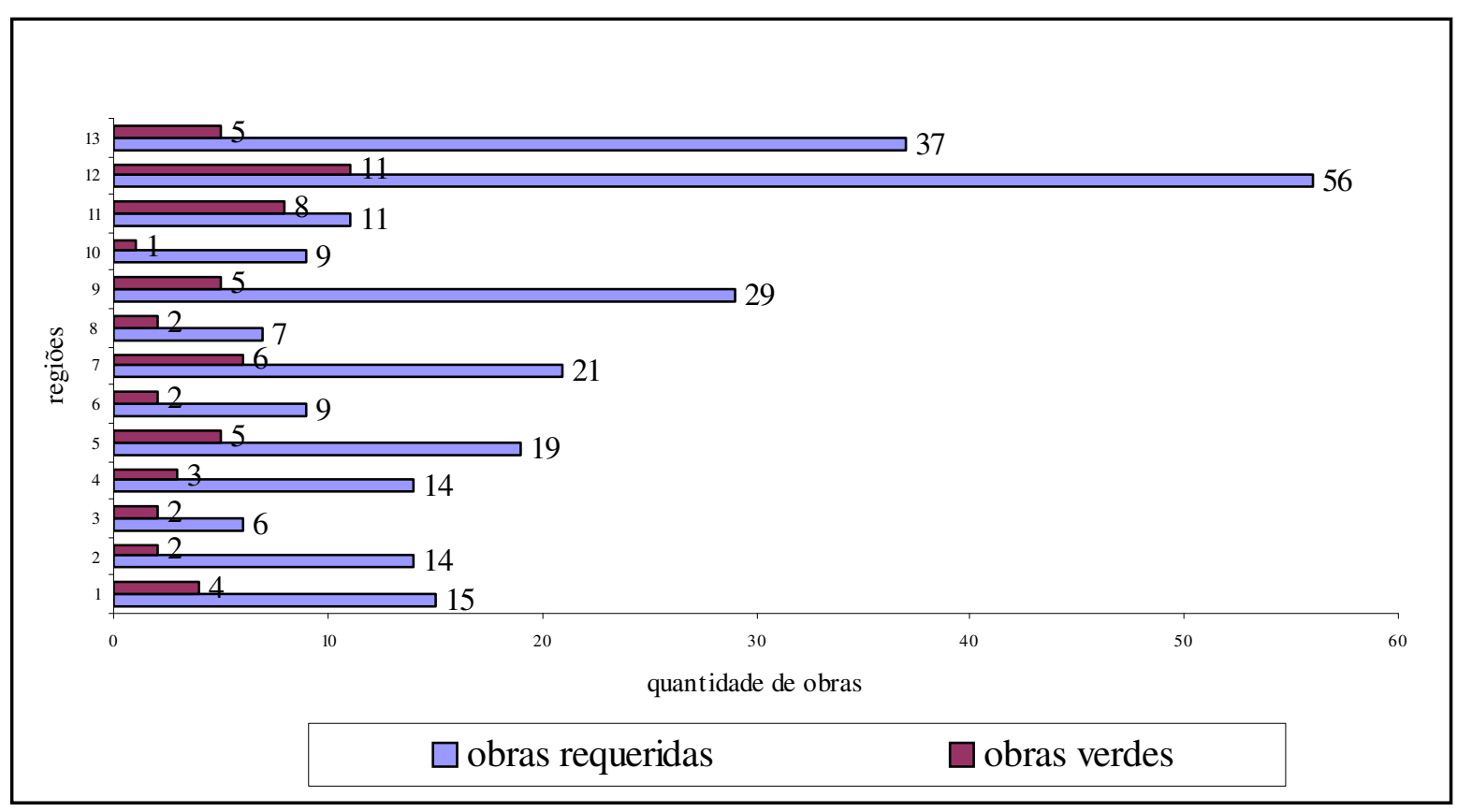

Quadro 9 - Proporção de demandas obras/obras verdes / 2001

\begin{tabular}{c|c}
\hline Região & Proporção \\
\hline 1 & $4 / 1$ \\
\hline 2 & $7 / 1$ \\
\hline 3 & $3 / 1$ \\
\hline 4 & $5 / 1$ \\
\hline 5 & $4 / 1$ \\
\hline 6 & $2 / 1$ \\
\hline 7 & $3 / 1$ \\
\hline 8 & $3 / 1$ \\
\hline 9 & $6 / 1$ \\
\hline 10 & $9 / 1$ \\
\hline 11 & $2 / 1$ \\
\hline 12 & $5 / 1$ \\
\hline 13 & $7 / 1$ \\
\hline Total & $\mathbf{5 / 1}$ \\
\hline
\end{tabular}


No ano de 2002, verificamos a continuidade do padrão anterior no que se refere grande solicitação por praças com 19\% das demandas, galerias pluviais com 18\%, áreas de lazer com $13 \%$. Fator importante nesse momento é a constatação da abertura de um leque maior nos itens solicitados (Gráfico 3).

De nossa perspectiva, acreditamos que os participantes, após o encaminhamento de obras que consideravam mais urgentes, começam a solicitar outras que consideravam não tão importantes. Por conta da observação direta, constatamos que: (a) a análise não pode ser feita como sendo um ato fruto da reflexão por parte de todos os participantes, pois a maioria tem nas "obras verdes" a idéia de resolução de questões pontuais de sua região; (b) por outro lado, também não podemos deixar de indicar que uma parcela, ainda que menor desses participantes, está com um olhar mais "aguçado" para outras questões urbanas importantes, como as ambientais. Essa indicação pode ser exemplificada por algumas das solicitações serem abrangentes, isto é, extrapolando as regiões e alcançando a totalidade do espaço da cidade, como: (a) a ampliação do programa de coleta seletiva que, no ano de 2002, estava em fase de implantação experimental apenas em alguns bairros; (b) aumento dos pedidos para o tratamento de esgoto; (c) a inclusão de pedidos para projetos de preservação e recuperação de APP's etc.

Apesar dessa mudança, no confronto entre os Gráficos 3 e 4 (Quadro 10), a proporção entre as solicitações por outras obras e obras verdes aumentou se comparada ao ano anterior - 8/1 (Quadro 9), contrapondo-se à proporção do ano anterior, que foi de 5/1, mas, ao mesmo tempo, observamos um salto qualitativo nessas demandas. 
Gráfico 3 - Total de Demandas Verdes / 2002

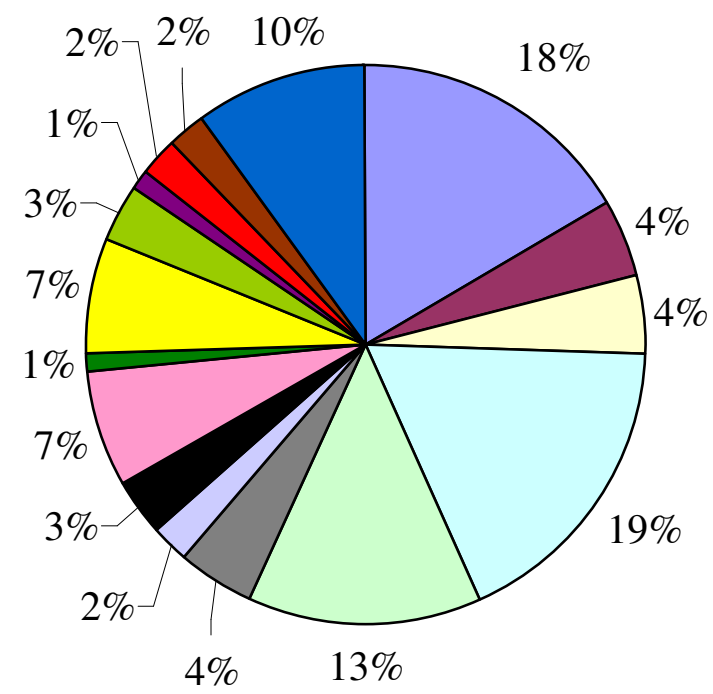

\begin{tabular}{|c|c|c|c|}
\hline$\square$ galerias pluviais & $\square$ tratamento es goto & $\square$ rede esgoto & $\square$ praças \\
\hline$\square$ áreas de lazer & 口enchentes & $\square$ erosão & a lixeiras \\
\hline$\square$ projetos de preservação & $\square$ áreas verdes & $\square$ coleta seletiva & $\square$ campanhas ambientais \\
\hline$\square$ poluição industrial & $\square$ poluição sonora & $\square$ queimadas & $\square$ arborização urbana \\
\hline
\end{tabular}

\section{Gráfico 4 - Confronto por Região entre Demandas Verdes e as Demais / 2002}

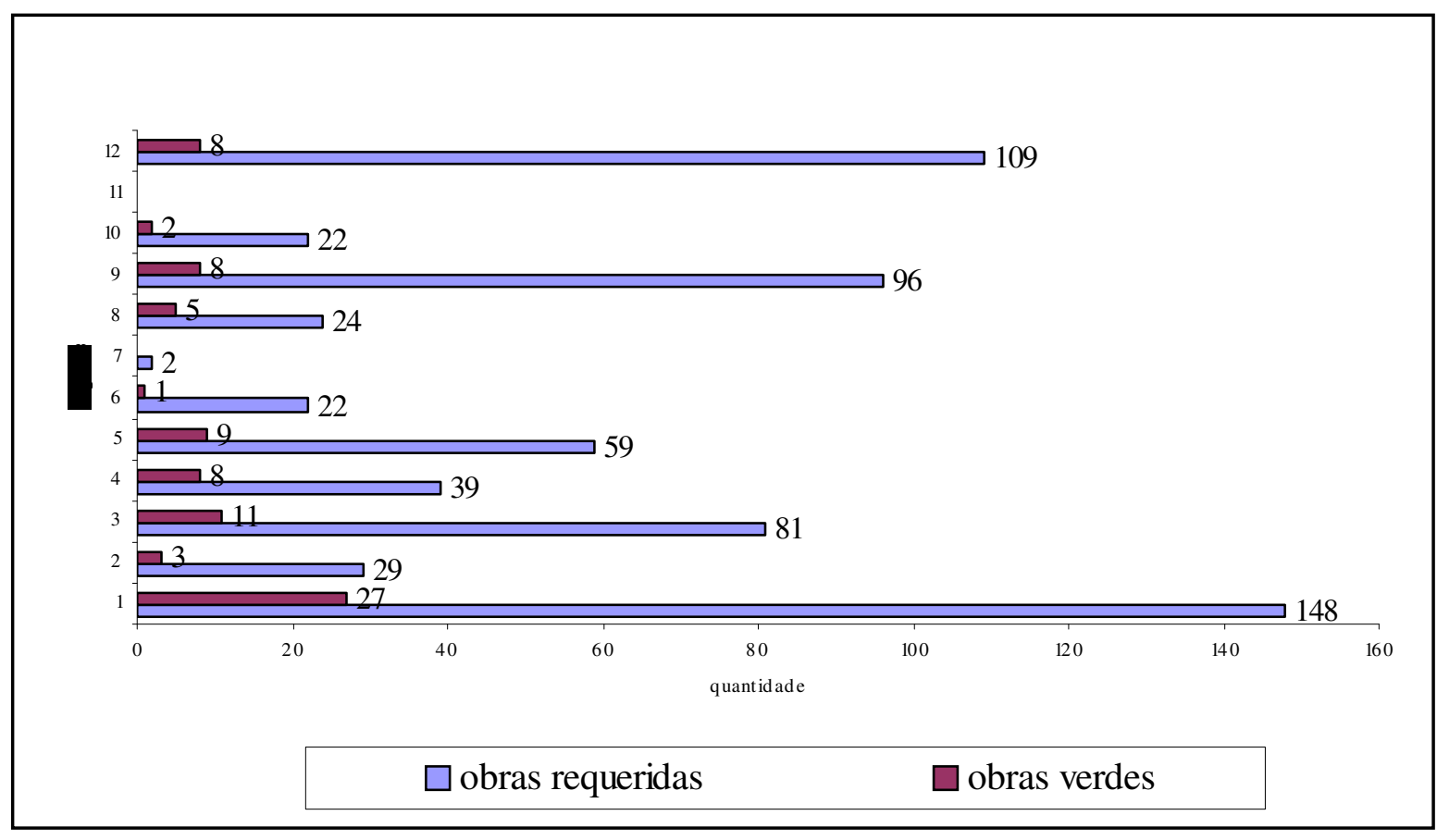




\begin{tabular}{c|c}
\hline \multicolumn{2}{|c}{$\begin{array}{c}\text { Quadro 10 / Proporção de demandas - } \\
\text { obras/obras verdes / 2002 }\end{array}$} \\
\hline Região & Proporção \\
\hline 1 & $5 / 1$ \\
\hline 2 & $10 / 1$ \\
\hline 3 & $7 / 1$ \\
\hline 4 & $5 / 1$ \\
\hline 5 & $6 / 1$ \\
\hline 6 & $22 / 1$ \\
\hline 7 & sem solicitações por obras verdes \\
\hline 8 & $5 / 1$ \\
\hline 9 & $12 / 1$ \\
\hline 10 & $11 / 1$ \\
\hline 11 & sem solicitações por obras verdes \\
\hline 12 & $14 / 1$ \\
\hline Total & $\mathbf{8 / 1}$ \\
\hline
\end{tabular}

No ano de 2003, ainda verificamos o grande aumento da demanda por áreas de lazer com $51 \%$ das demandas, seguido por praças com $22 \%$, áreas verdes com $13 \%$ e arborização urbana com 7\% (Gráfico 5). Essa configuração reafirma a carência que os citadinos têm de áreas de encontro e de lazer, assim como, a necessidade que sentem da presença de espaços verdes. Esse fato não perde sua relevância mesmo com a possível presença de duas importantes variáveis: essas demandas podem não estar sendo aprovadas para deliberação, ou não estão sendo concluídas em tempo hábil, por isso, a insistência nessas solicitações. É mister também ressaltar a inclusão, entre as solicitações, do item arborização urbana por sua qualidade de abrangência, isto é, alcançar a cidade como um todo, ao contrário de outras solicitações cujo caráter característico é de ser mais pontual, no nível das regiões e/ou bairros. Esse dado pode ser indício da continuidade ou ampliação do processo de conscientização a respeito das questões ambientais urbanas, já detectadas anteriormente.

Dois fatores importantes chamam nossa atenção na comparação com os anos anteriores e entre os Gráficos 5 e 6 . Na análise do Gráfico 6 é nítida a queda do número de 
demandas. Para tal situação, temos cinco fatores que juntos influíram para essa configuração:

(a) as obras consideradas mais urgentes já haviam sido solicitadas, ou solucionadas nos anos anteriores;

(b) pela própria experiência dos anos anteriores e pela gradual compreensão do funcionamento da máquina administrativa, os participantes passaram a solicitar somente as obras mais emergenciais, deixando para outro momento as que poderiam ser requeridas posteriormente;

(c) como consequiência direta do item (b), não vendo a maioria de suas solicitações atendidas, os participantes deixaram de requerer um grande número de obras, por saberem que elas não seriam solucionadas em curto prazo;

(d) pela modificação feita pelo COP na forma de solicitação e aprovação de demandas;

(e) pelo trabalho de esclarecimento feito pelo COP das importantes questões ambientais das regiões urbanas e do município.

Por conta desse processo, ao confrontar os Gráficos 5 e 6 (Quadro 11), verificamos uma queda na proporção obras/obras verdes, exemplos:

(a) a região 3 cuja proporção no ano de 2002 era de 7/1 e em 2003 caiu para 1/1;

(b) a região 1 que no ano de 2002 era de 5/1 e em 2003 caiu para 3/1;

(c) a região 12 cuja proporção em 2002 era de 14/1 e que em 2003 caiu para 3/1. 


\section{Gráfico 5 - Total de Demandas Verdes / 2003}

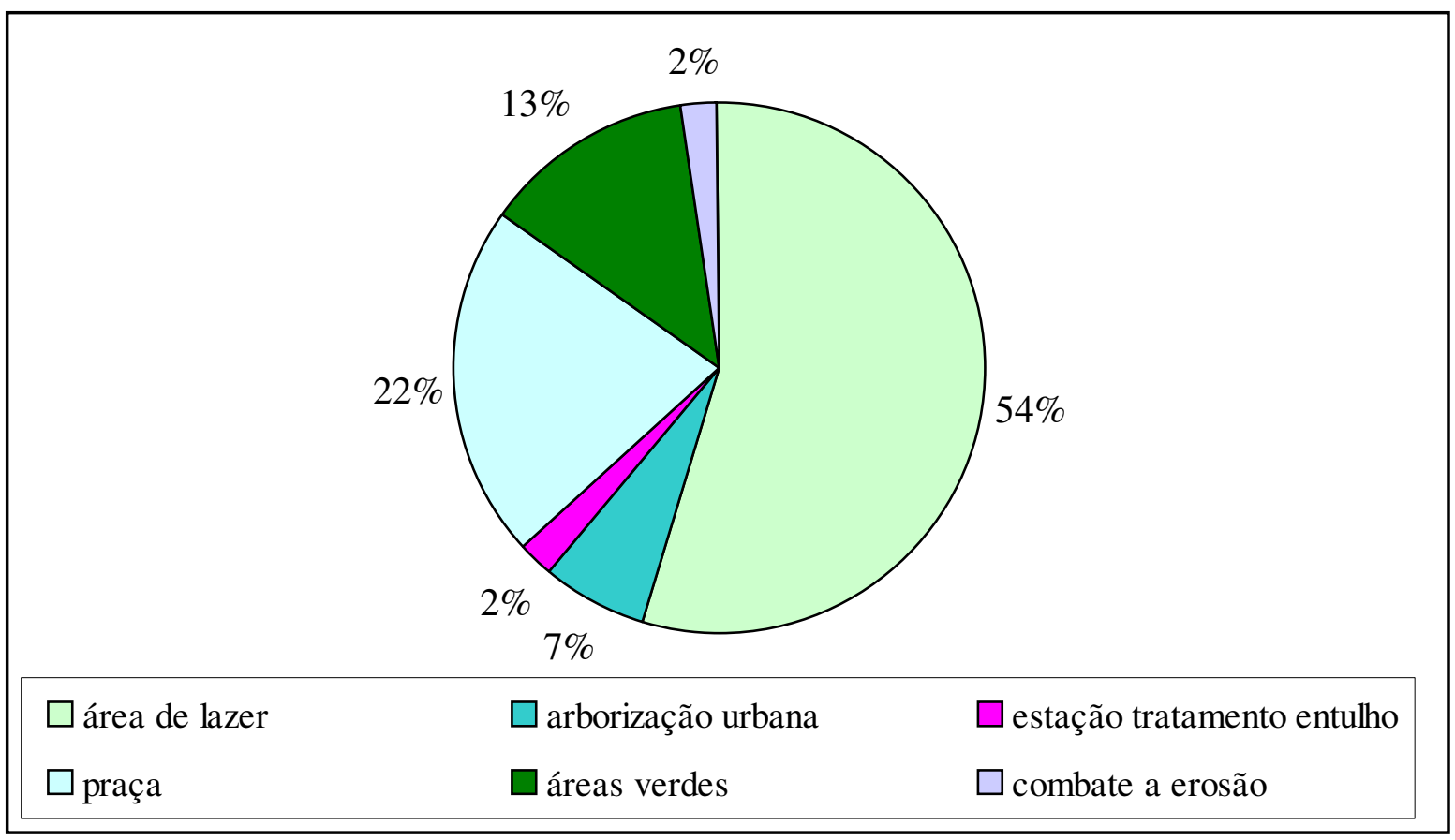

Gráfico 6 - Confronto por Região entre Demandas Verdes e as Demais / 2003

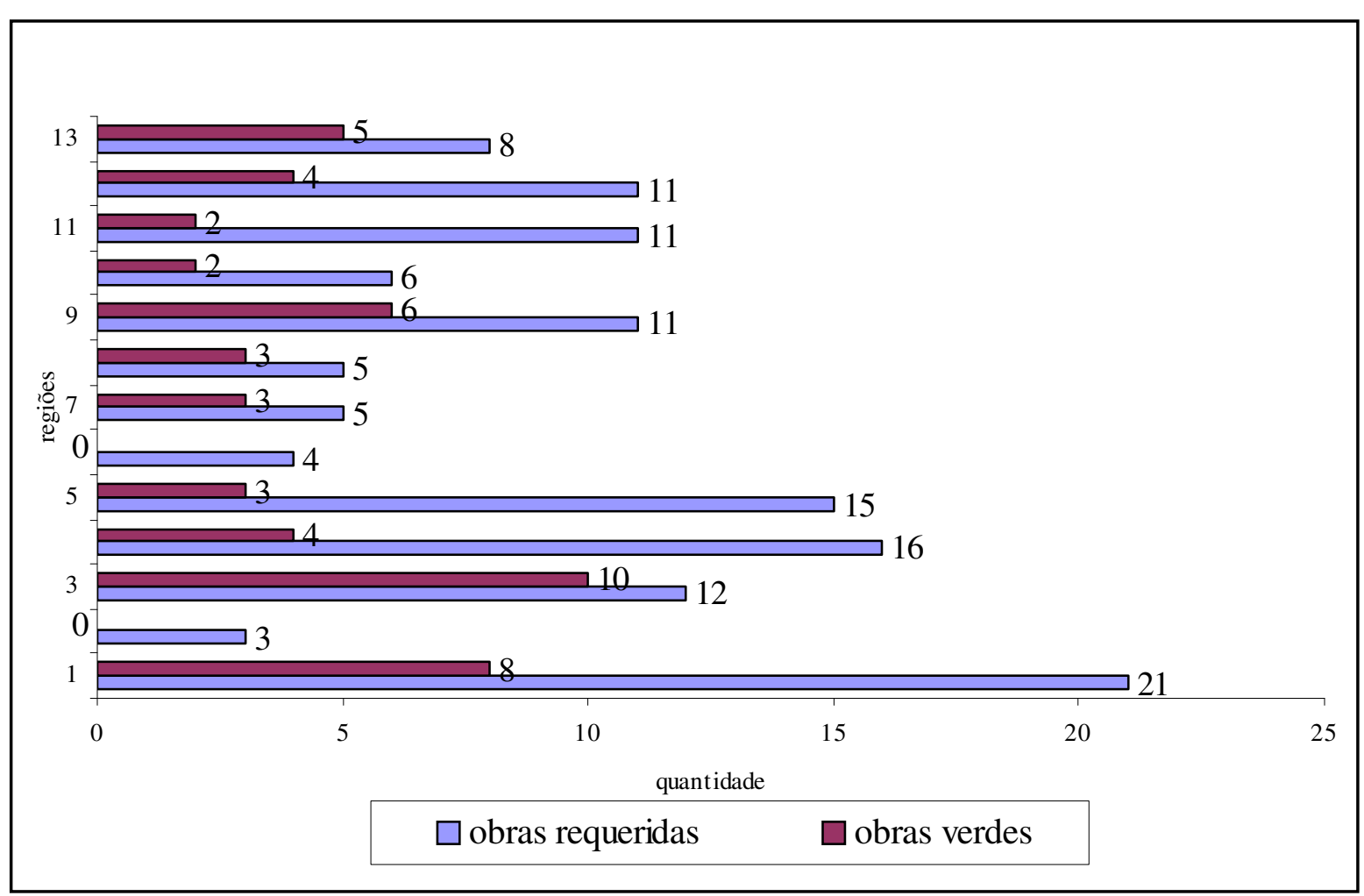




\begin{tabular}{|c|c}
\hline \multicolumn{2}{|c|}{$\begin{array}{c}\text { Quadro 11 - Proporção de demandas - } \\
\text { obras/obras verdes / 2003 }\end{array}$} \\
\hline Região & Proporção \\
\hline 1 & $3 / 1$ \\
\hline 2 & sem solicitações por obras verdes \\
\hline 3 & $1 / 1$ \\
\hline 4 & $4 / 1$ \\
\hline 5 & $5 / 1$ \\
\hline 6 & sem solicitações por obras verdes \\
\hline 7 & $2 / 1$ \\
\hline 8 & $2 / 1$ \\
\hline 9 & $2 / 1$ \\
\hline 10 & $3 / 1$ \\
\hline 11 & $5 / 1$ \\
\hline 12 & $3 / 1$ \\
\hline 13 & $2 / 1$ \\
\hline Total & $\mathbf{3} / \mathbf{1}$ \\
\hline
\end{tabular}

No ano de 2004, ainda verificamos a contínua demanda por praças com 20\%, seguida por arborização urbana com 15\%, áreas de lazer com 14\% e galerias pluviais com 12\% (Gráfico 7). Essa configuração reafirma o modelo de urbanização adotado pelo município que gerou carência desses espaços, assim como, a possível não solução dessas mesmas demandas requeridas nos anos anteriores. Ressaltamos a continuidade das solicitações de arborização urbana, indício da continuidade ou ampliação do processo de conscientização dos citadinos a respeito das questões ambientais, mais amplas detectados anteriormente.

Dois fatores importantes nos chamam atenção na comparação com os anos anteriores e entre os Gráficos 7 e 8 (Quadro 12). Na análise do Gráfico 8, é nítida a queda do número de demandas, configurando que os fatores sugeridos anteriormente podem estar já enraizados na percepção dos participantes. 


\section{Gráfico 7 - Total de Demandas Verdes / 2004}

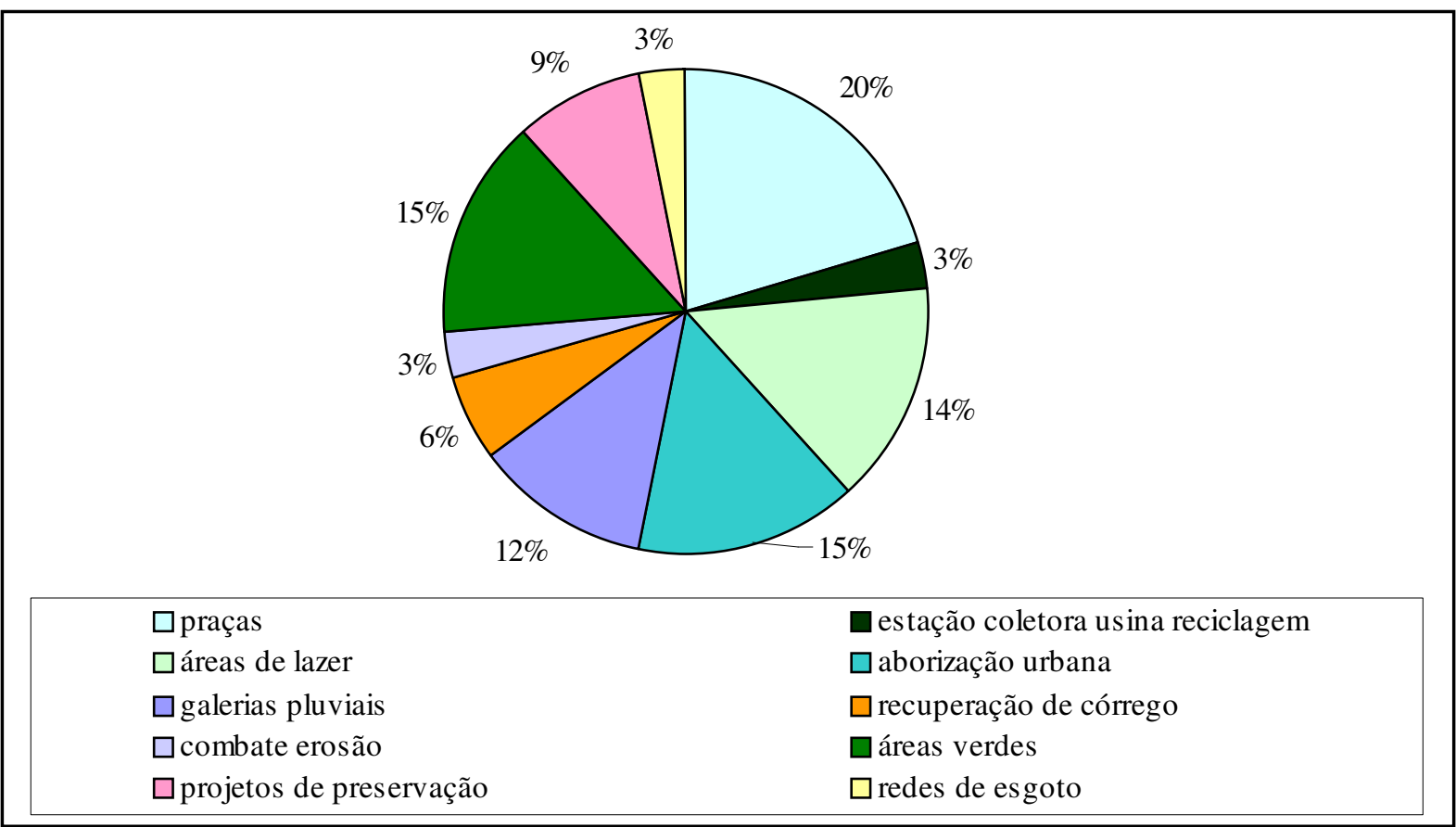

\section{Gráfico 8- Confronto por Região entre Demandas Verdes e as Demais / 2004}

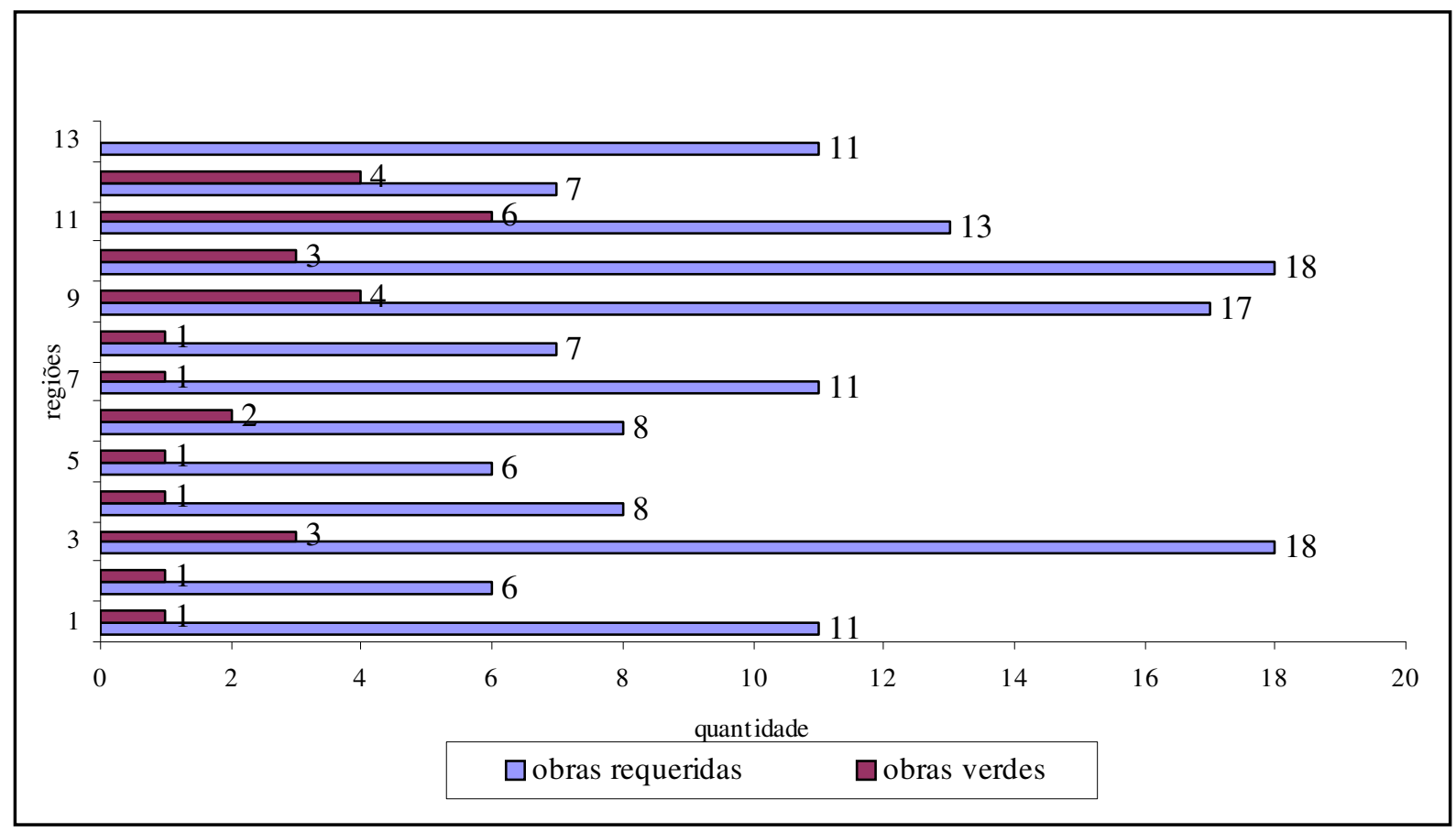


Quadro 12 - Proporção de demandas obras/obras verdes / 2004

\begin{tabular}{c|c}
\hline Região & Proporção \\
\hline 1 & $11 / 1$ \\
\hline 2 & $6 / 1$ \\
\hline 3 & $6 / 1$ \\
\hline 4 & $8 / 1$ \\
\hline 5 & $6 / 1$ \\
\hline 6 & $2 / 1$ \\
\hline 7 & $11 / 1$ \\
\hline 8 & $7 / 1$ \\
\hline 9 & $4 / 1$ \\
\hline 10 & $6 / 1$ \\
\hline 11 & $2 / 1$ \\
\hline 12 & $2 / 1$ \\
\hline 13 & sem solicitações por obras verdes \\
\hline Total & $\mathbf{5 / 1}$ \\
\hline
\end{tabular}




\section{Gráfico 9 - Total de Demandas Verdes / 2001 a 2004}

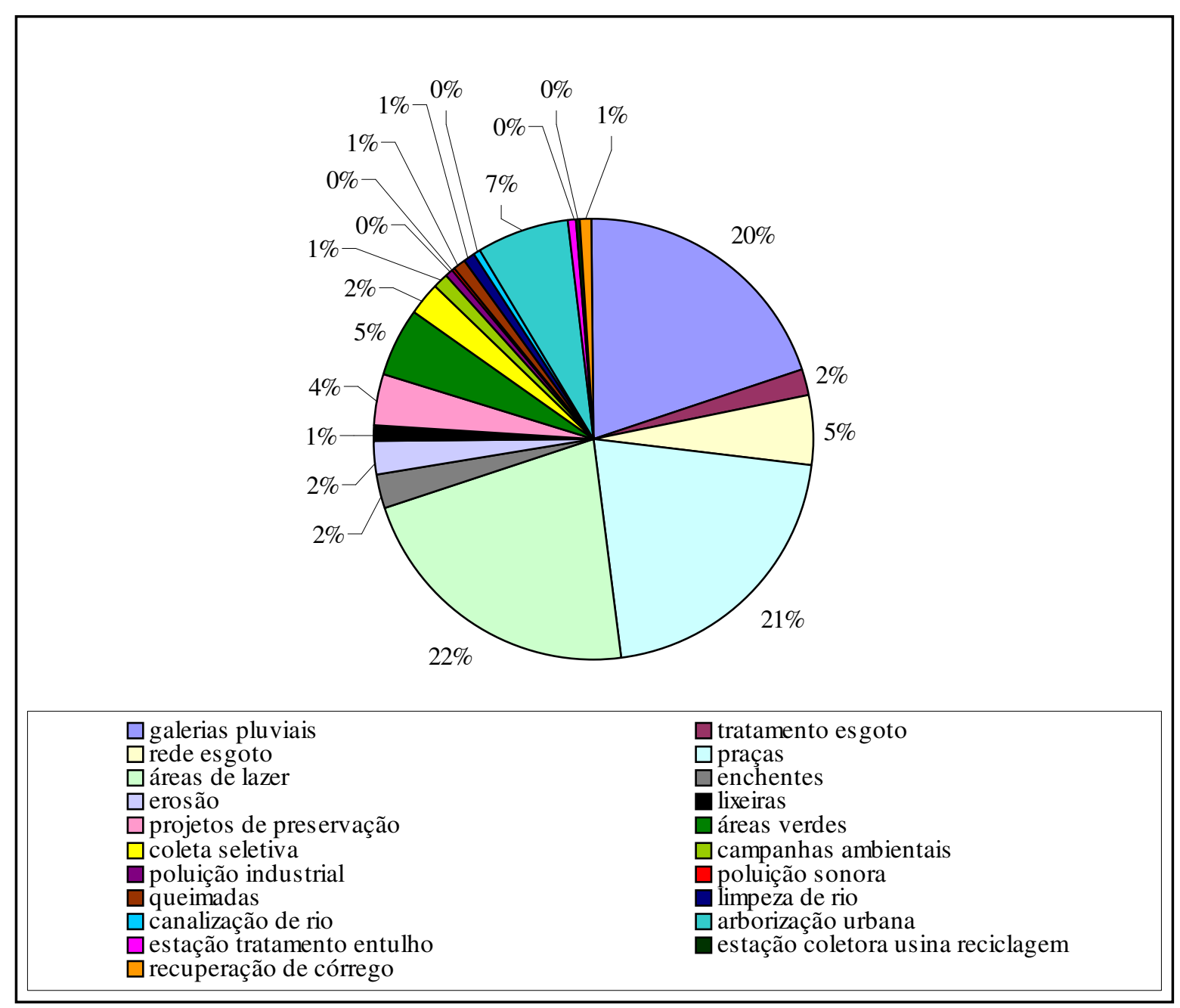


Gráfico 10 - Confronto por Região entre Demandas Verdes e as Demais / 2001 a 2004

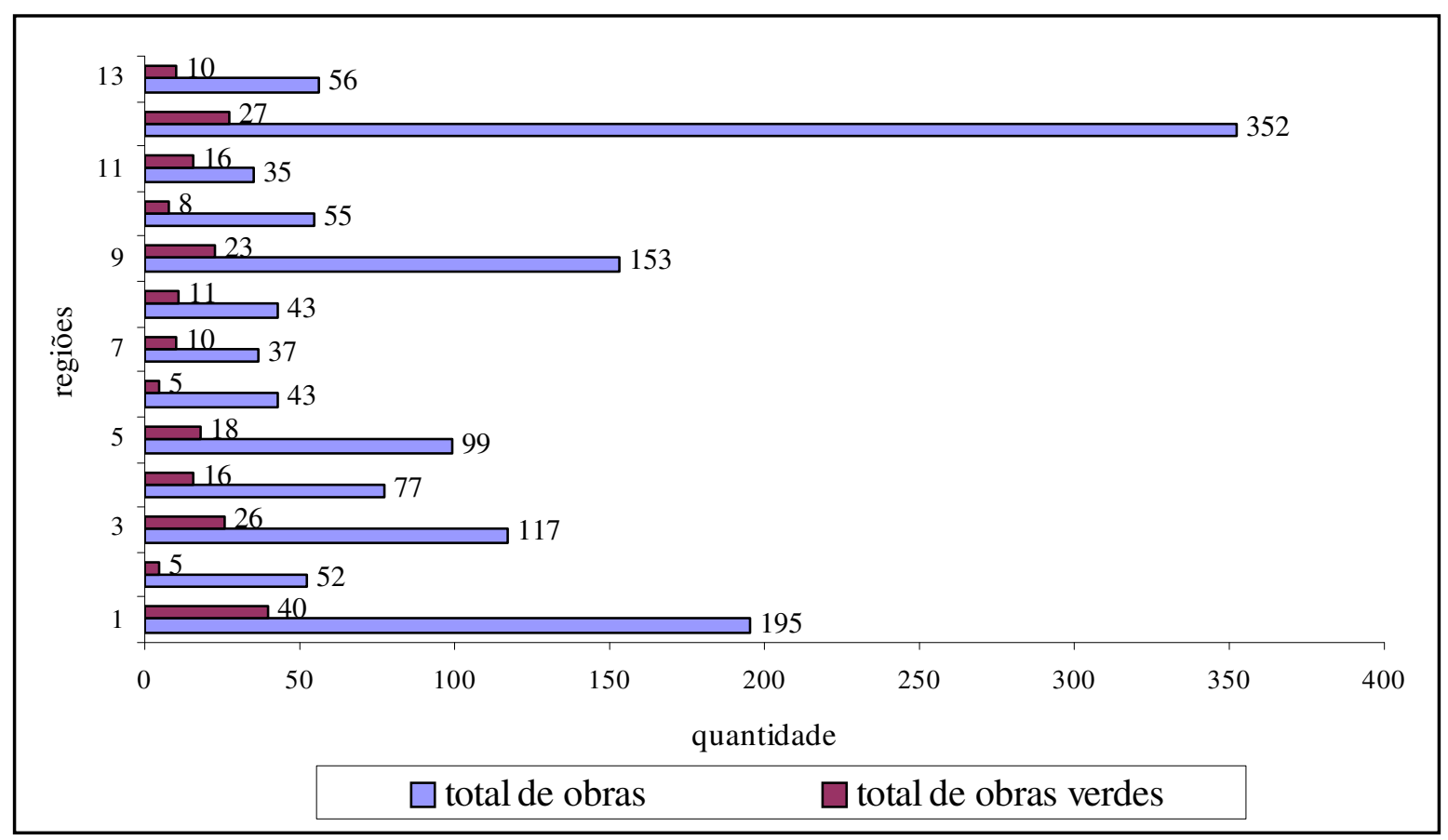

Quadro 13 - Proporção de demandas - obras/obras verdes / 2001 a 2004

\begin{tabular}{c|c|c|c|c}
\hline \multirow{2}{*}{ Regiões } & \multicolumn{4}{|c}{ Proporção } \\
\cline { 2 - 5 } & $\mathbf{2 0 0 1}$ & $\mathbf{2 0 0 2}$ & $\mathbf{2 0 0 3}$ & $\mathbf{2 0 0 4}$ \\
\hline 1 & $4 / 1$ & $5 / 1$ & $3 / 1$ & $11 / 1$ \\
\hline 2 & $7 / 1$ & $10 / 1$ & - & $6 / 1$ \\
\hline 3 & $3 / 1$ & $7 / 1$ & $1 / 1$ & $6 / 1$ \\
\hline 4 & $5 / 1$ & $5 / 1$ & $4 / 1$ & $8 / 1$ \\
\hline 5 & $4 / 1$ & $6 / 1$ & $5 / 1$ & $6 / 1$ \\
\hline 6 & $2 / 1$ & $22 / 1$ & - & $4 / 1$ \\
\hline 7 & $3 / 1$ & - & $2 / 1$ & $11 / 1$ \\
\hline 8 & $3 / 1$ & $5 / 1$ & $2 / 1$ & $7 / 1$ \\
\hline 9 & $6 / 1$ & $12 / 1$ & $2 / 1$ & $4 / 1$ \\
\hline 10 & $9 / 1$ & $11 / 1$ & $3 / 1$ & $6 / 1$ \\
\hline 11 & $2 / 1$ & - & $5 / 1$ & $2 / 1$ \\
\hline 12 & $5 / 1$ & $14 / 1$ & $3 / 1$ & $2 / 1$ \\
\hline 13 & $7 / 1$ & - & $2 / 1$ & - \\
\hline Total & $\mathbf{5 / 1}$ & $\mathbf{8 / 1}$ & $\mathbf{3 / 1}$ & $\mathbf{5 / 1}$ \\
\hline
\end{tabular}


Analisando o Quadro 9, ressaltamos um dado quantitativo relevante, entretanto, essas solicitações por obras verdes ainda carecem de reflexividade e compreensão da importância dos temas ambientais referentes ao espaço total do município, ou seja, ainda é preciso buscar um avanço em termos qualitativos.

De posse dos dados referentes às demandas verdes em cada uma das regiões em que foi dividido o município, elaboramos um diagnóstico das demandas verdes (Quadro 14) e mapas temáticos específicos de cada uma dessas demandas. Consideramos que assim podese obter uma melhor visualização das carências de cada região, ou seja, uma análise comparativa das demandas nas 13 regiões, servindo de parâmetro para confirmar o modelo arcaico e deletério de urbanização do município, independentemente do perfil territorial, ou socioeconômico característicos dessas regiões.

\section{Quadro 14 - Diagnóstico de Demandas Verdes por Região / de 2001 a 2004}

\begin{tabular}{|c|c|c|c|c|}
\hline \multirow[t]{2}{*}{ Regiões } & \multicolumn{4}{|c|}{ Demandas } \\
\hline & 2001 & 2002 & 2003 & 2004 \\
\hline 01 & $\begin{array}{l}50 \% \text { áreas de lazer } \\
25 \% \text { tratamento de } \\
\text { esgoto } \\
25 \% \text { galerias pluviais }\end{array}$ & $\begin{array}{c}26 \% \text { arborização } \\
\text { urbana } \\
19 \% \text { áreas de lazer } \\
13 \% \text { projetos de } \\
\text { preservação }\end{array}$ & $\begin{array}{c}37 \% \text { áreas de lazer } \\
25 \% \text { praças } \\
25 \% \text { arborização } \\
\text { urbana }\end{array}$ & $\begin{array}{l}50 \% \text { arborização } \\
\text { urbana } \\
50 \% \text { projetos de } \\
\text { preservação }\end{array}$ \\
\hline 02 & $100 \%$ galerias pluviais & $\begin{array}{l}67 \% \text { galerias pluviais } \\
33 \% \text { redes de esgoto }\end{array}$ & $100 \%$ galerias pluviais & $\begin{array}{c}50 \% \text { praças } \\
50 \% \text { áreas de lazer }\end{array}$ \\
\hline 03 & $100 \%$ praças & $\begin{array}{c}50 \% \text { praças } \\
20 \% \text { áreas de lazer } \\
20 \% \text { lixeiras }\end{array}$ & $\begin{array}{c}90 \% \text { áreas de lazer } \\
10 \% \text { praças }\end{array}$ & $\begin{array}{c}\text { 67\% áreas de lazer } \\
33 \% \text { estação coletora } \\
\text { para usina de } \\
\text { reciclagem }\end{array}$ \\
\hline 04 & $\begin{array}{c}75 \% \text { praças } \\
25 \% \text { áreas de lazer }\end{array}$ & $\begin{array}{c}44 \% \text { praças } \\
\text { 14\% galerias pluviais; } \\
\text { enchentes; projetos de } \\
\text { preservação; coleta } \\
\text { seletiva }\end{array}$ & $100 \%$ praças & $\begin{array}{c}\text { 100\% arborização } \\
\text { urbana }\end{array}$ \\
\hline
\end{tabular}




\begin{tabular}{|c|c|c|c|c|}
\hline 05 & $\begin{array}{c}66 \% \text { galerias pluviais } \\
17 \% \text { redes de esgoto } \\
17 \% \text { praças }\end{array}$ & $\begin{array}{c}56 \% \text { galerias pluviais } \\
22 \% \text { campanhas } \\
\text { ambientais } \\
11 \% \text { redes de esgoto; } \\
\text { áreas de lazer }\end{array}$ & $\begin{array}{c}50 \% \text { praças } \\
50 \% \text { áreas de lazer }\end{array}$ & $\begin{array}{c}100 \% \text { galerias } \\
\text { pluviais }\end{array}$ \\
\hline 06 & $\begin{array}{l}67 \% \text { galerias pluviais } \\
33 \% \text { áreas de lazer }\end{array}$ & - & - & - \\
\hline 07 & $\begin{array}{l}\text { 43\% galerias pluviais } \\
29 \% \text { áreas de lazer } \\
14 \% \text { praças; enchentes }\end{array}$ & $100 \%$ áreas de lazer & $\begin{array}{c}67 \% \text { áreas de lazer } \\
33 \% \text { praças }\end{array}$ & $100 \%$ praças \\
\hline \multirow[t]{2}{*}{08} & $\begin{array}{c}67 \% \text { galerias pluviais } \\
33 \% \text { enchentes }\end{array}$ & $\begin{array}{c}40 \% \text { galerias pluviais } \\
40 \% \text { enchentes } \\
20 \% \text { projetos de } \\
\text { preservação }\end{array}$ & $100 \%$ áreas verdes & $\begin{array}{c}100 \% \text { arborização } \\
\text { urbana }\end{array}$ \\
\hline & 2001 & 2002 & 2003 & 2004 \\
\hline 09 & $\begin{array}{l}33 \% \text { áreas de lazer } \\
33 \% \text { praças } \\
17 \% \text { canalização de } \\
\text { rio; erosão }\end{array}$ & $\begin{array}{c}34 \% \text { praças } \\
33 \% \text { coleta seletiva } \\
25 \% \text { tratamento de } \\
\text { esgoto }\end{array}$ & $\begin{array}{c}40 \% \text { praças } \\
40 \% \text { áreas de lazer } \\
20 \% \text { áreas verdes }\end{array}$ & $\begin{array}{c}25 \% \text { áreas de lazer; } \\
\text { recuperação de curso } \\
\text { d'água; redes de } \\
\text { esgoto; galerias } \\
\text { pluviais }\end{array}$ \\
\hline 10 & $100 \%$ erosão & $\begin{array}{c}50 \% \text { erosão } \\
50 \% \text { enchentes }\end{array}$ & $100 \%$ áreas de lazer & $\begin{array}{c}\text { 34\% recuperação de } \\
\text { curso d'água } \\
33 \% \text { erosão } \\
33 \% \text { áreas de lazer }\end{array}$ \\
\hline 11 & $\begin{array}{l}37 \% \text { galerias pluviais } \\
25 \% \text { limpeza de curso } \\
\text { d'água } \\
25 \% \text { áreas de lazer }\end{array}$ & - & $\begin{array}{l}50 \% \text { áreas de lazer } \\
50 \% \text { áreas verdes }\end{array}$ & $\begin{array}{c}40 \% \text { praças } \\
40 \% \text { projetos de } \\
\text { preservação } \\
20 \% \text { galerias pluviais }\end{array}$ \\
\hline 12 & $\begin{array}{c}54 \% \text { praças } \\
31 \% \text { galerias pluviais } \\
15 \% \text { redes de esgoto }\end{array}$ & $\begin{array}{c}37 \% \text { praças } \\
25 \% \text { galerias pluviais } \\
25 \% \text { áreas de lazer }\end{array}$ & $\begin{array}{c}50 \% \text { áreas de lazer } \\
25 \% \text { praças } \\
25 \% \text { arborização } \\
\text { urbana }\end{array}$ & $\begin{array}{c}75 \% \text { praças } \\
25 \% \text { arborização } \\
\text { urbana }\end{array}$ \\
\hline 13 & $\begin{array}{l}43 \% \text { galerias pluviais } \\
29 \% \text { redes de esgoto } \\
14 \% \text { praças; áreas de } \\
\text { lazer }\end{array}$ & - & $\begin{array}{c}75 \% \text { áreas de lazer } \\
25 \% \text { erosão }\end{array}$ & - \\
\hline
\end{tabular}



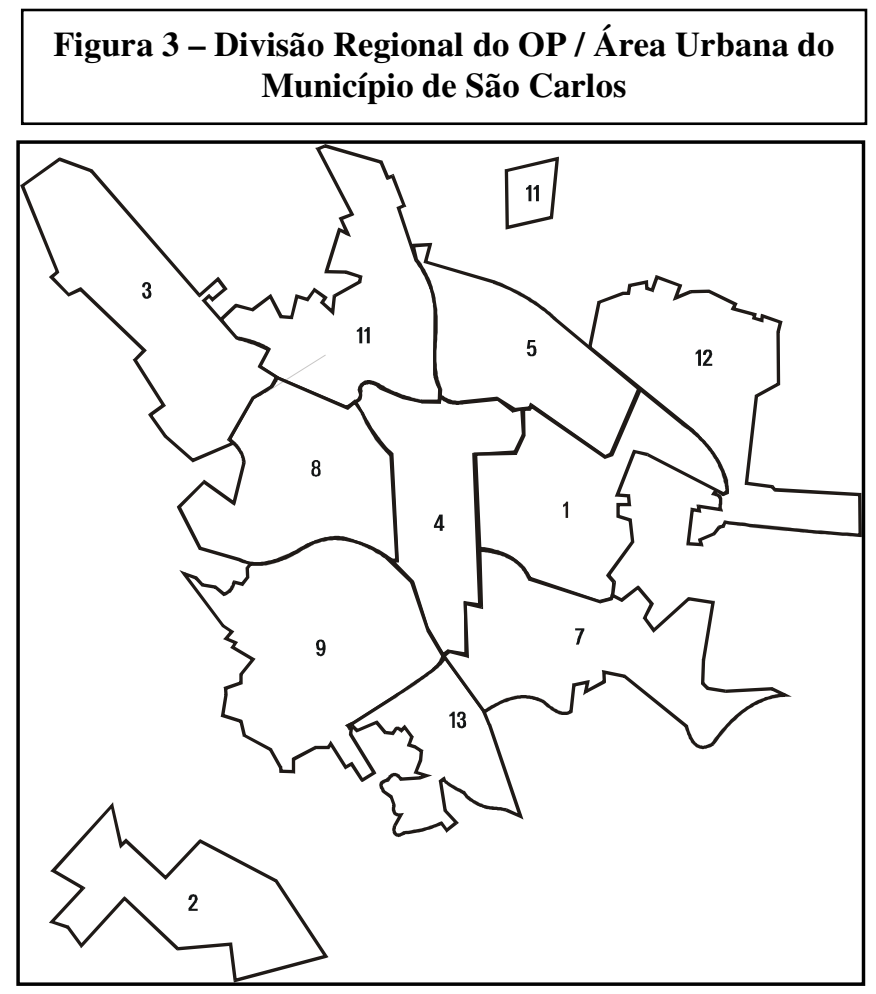

Quadro 2 - Divisão Regional do OP por Bairros / Área Urbana

\begin{tabular}{|c|c|}
\hline $\mathbf{R}$ & Bairros \\
\hline 01 & $\begin{array}{c}\text { V1. Nery, V1. Derigge, V1. Sto Antonio, Pq. Sabará, Conjunto Residencial Américo A. Margarido, Convívio D. Bosco, Jd. } \\
\text { Cardinalli, Pq. Primavera }\end{array}$ \\
\hline 02 & Cidade Aracy I e II, Antenor Garcia, Presidente Collor \\
\hline 03 & $\begin{array}{l}\text { Santa Felícia, Arnon de Mello, Santa Angelina, Aracê de Santo. Antonio I e II, Morada dos Deuses, Parque Fehr, Parque } \\
\text { Iguatemi, Residencial Paraty, Residencial Romeu Tortorelli, Santa Cruz, São Carlos I, II, III e IV }\end{array}$ \\
\hline 04 & Centro, Cidade Universitária, Conjunto Habitacional Sílvio Villari, Jardim Lutfalla, Jardim Macarenco, Vila Elizabeth \\
\hline 05 & $\begin{array}{l}\text { V1 São José, Jardim São João Batista, Jardim Santa Maria I, Tijuco Preto, Nova Estância, Chácara Paraíso, Parque } \\
\text { Estância Suíça, V1 Costa do Sol, V1 Jacobucci, }\end{array}$ \\
\hline 06 & Distrito de Santa Eudoxia \\
\hline 07 & $\begin{array}{c}\text { Castelo Branco, Vila Monteiro, V1 Marcelino, Azuville I e II, Centreville, Jardim Nova São Carlos, Jardim Ricetti, Parque } \\
\text { Itaipu, V1 Alpes, V1 Irene, V1 Lutfalla }\end{array}$ \\
\hline 08 & Planalto Paraíso, Jardim São Carlos, Parque Santa Mônica, Parque Faber \\
\hline 09 & $\begin{array}{c}\text { V1 Prado, V1 Boa Vista, V1 Bela Vista, Jd Botafogo, Jd Beatriz, Jd Medeiros, Jd das Torres, Mirante Bela Vista, V1 } \\
\text { Carmem, V1 Pelicano }\end{array}$ \\
\hline 10 & Água Vermelha, Tutoya do Vale, Tibaia S. Fernando I/II, Valparaíso I/II \\
\hline 11 & $\begin{array}{c}\text { Jd Nova Sta Paula, Jd Jockey Club, Jd Centenário, Cidade Jardim, Santa Marta, Jd Bandeirantes, Jd Hikare, Paulistano, } \\
\text { Santa Paula, Parque Delta }\end{array}$ \\
\hline 12 & $\begin{array}{c}\text { Parque Residencial Maria Stella Fagá, Jd Tangará, Jd Santa Maria II, Babilônia, Jd Munique, Parque Belvedere, } \\
\text { Residencial Itamaraty }\end{array}$ \\
\hline 13 & Jd. Cruzeiro do Sul, Jd Gonzaga, Jd Pacaembu, Jd. Monte Carlo, Santa Madre Cabrini \\
\hline
\end{tabular}


Figura - 12 - Demandas das Regiões do OP por Arborização Urbana / 2002

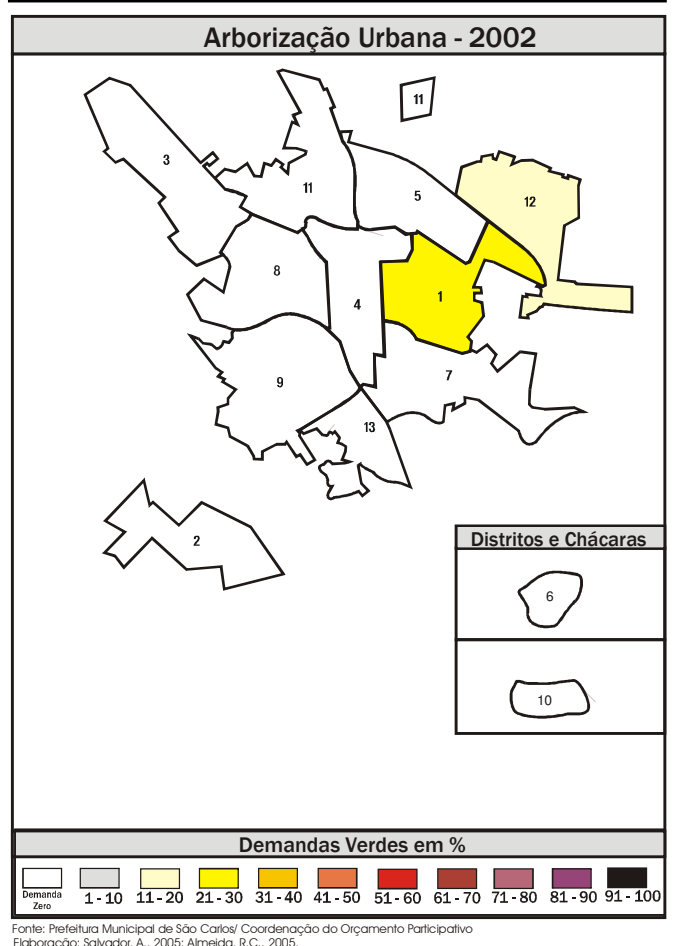

Figura 14 - Demandas das Regiões do OP por Arborização Urbana / 2004

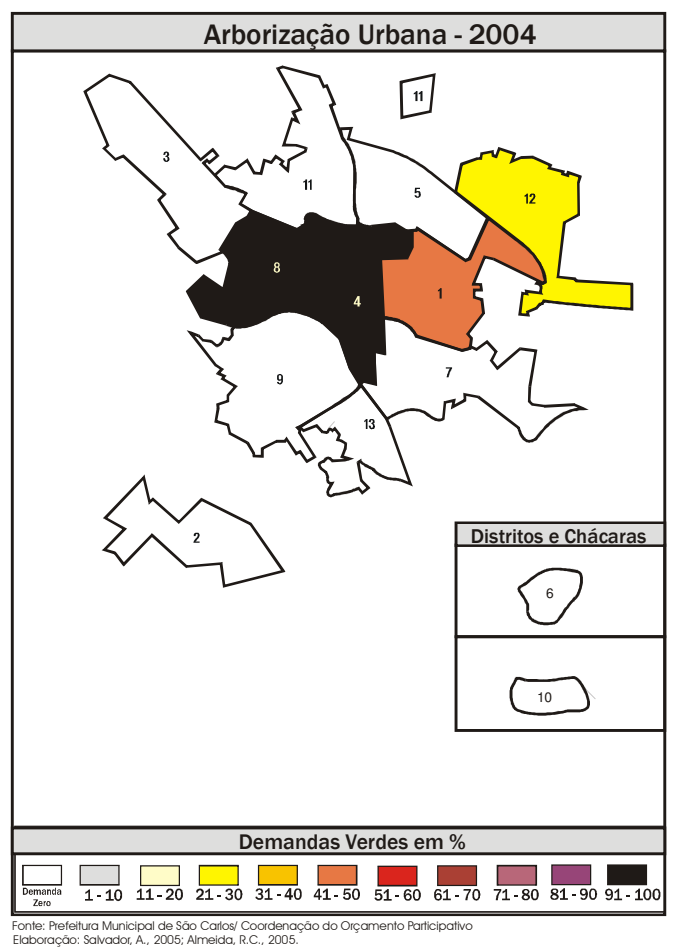

Figura - 13 - Demandas das Regiões do OP por Arborização Urbana / 2003

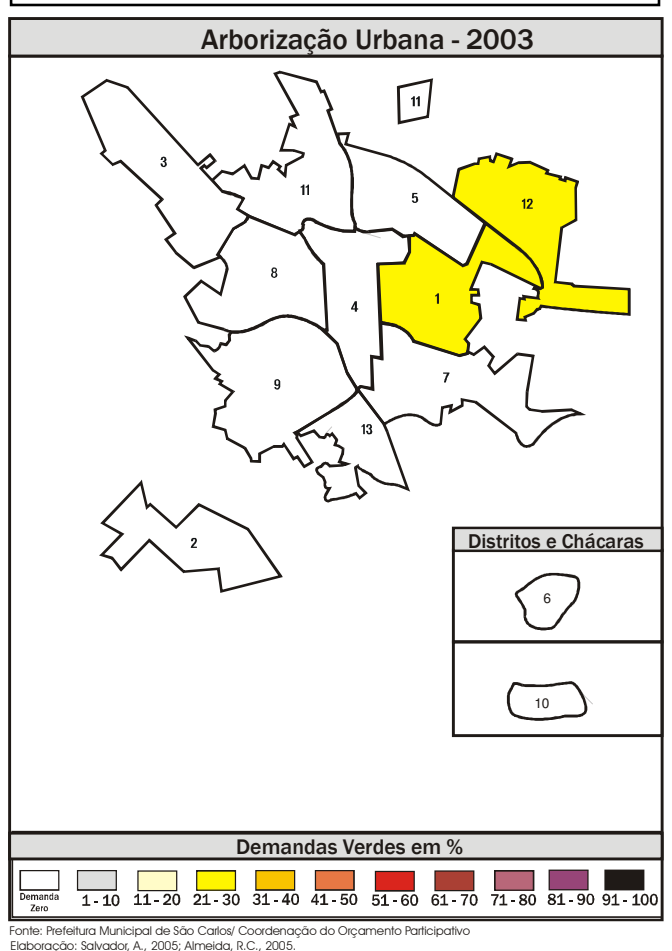


Figura 15 - Demandas das Regiões do OP por Área de Lazer / 2001

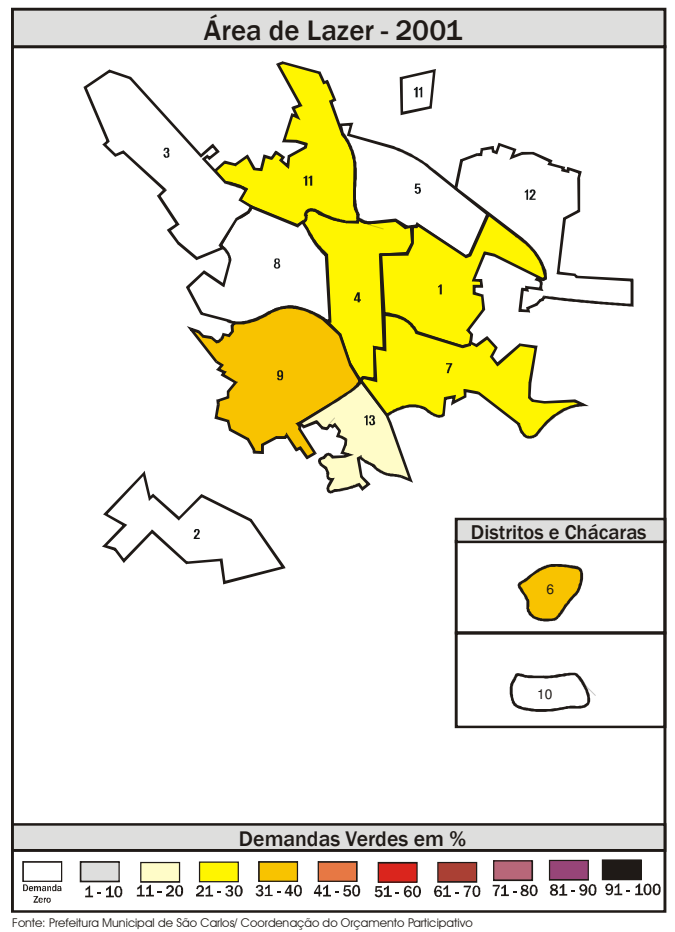

Figura 17 - Demandas das Regiões do OP por Área de Lazer / 2003

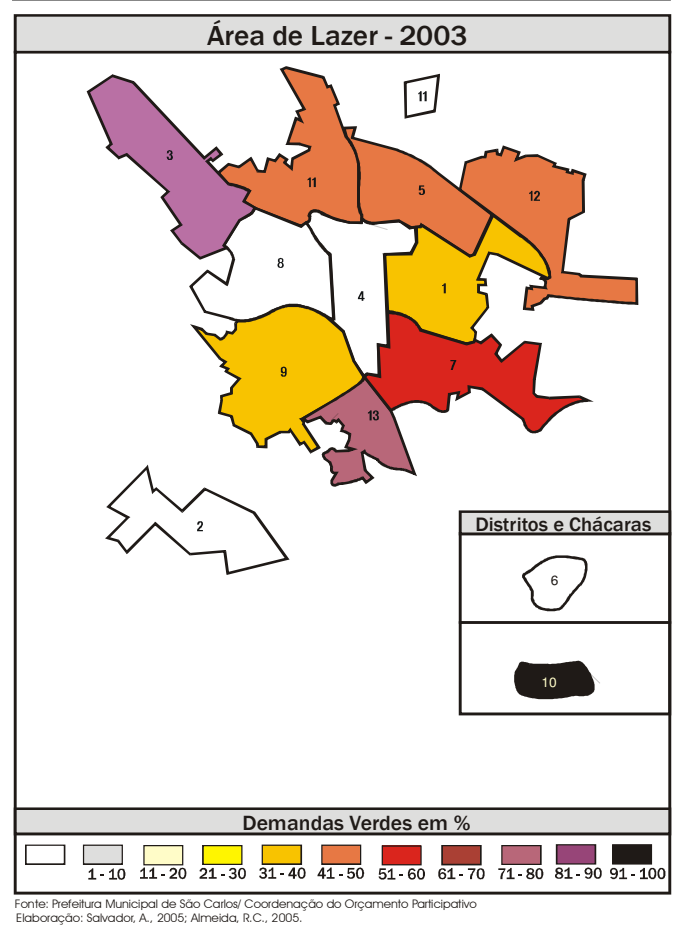

Figura 16 - Demandas das Regiões do OP por Área de Lazer / 2002

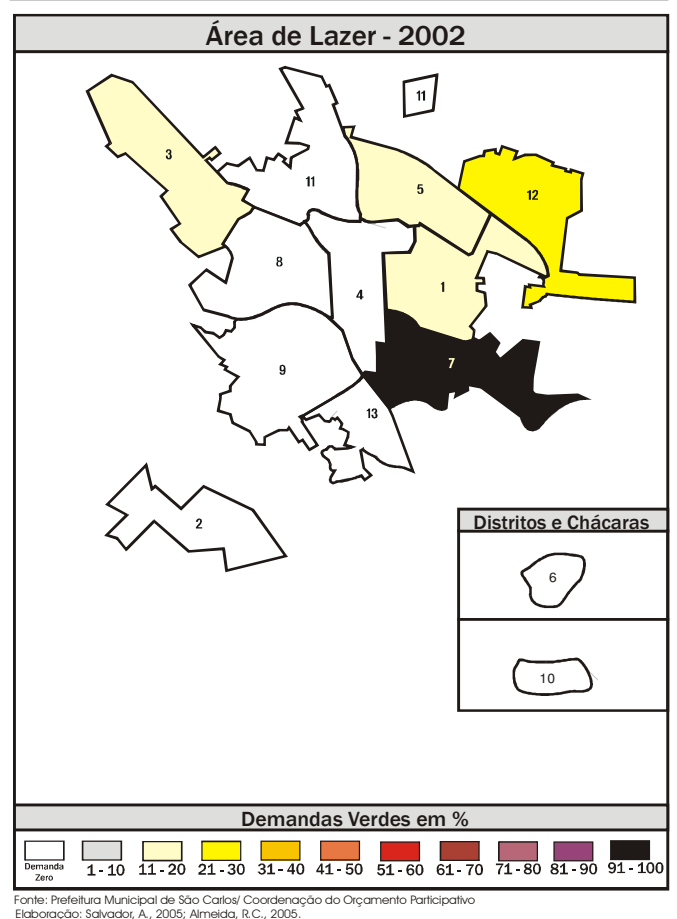

Figura 18 - Demandas das Regiões do OP por Área de Lazer / 2004

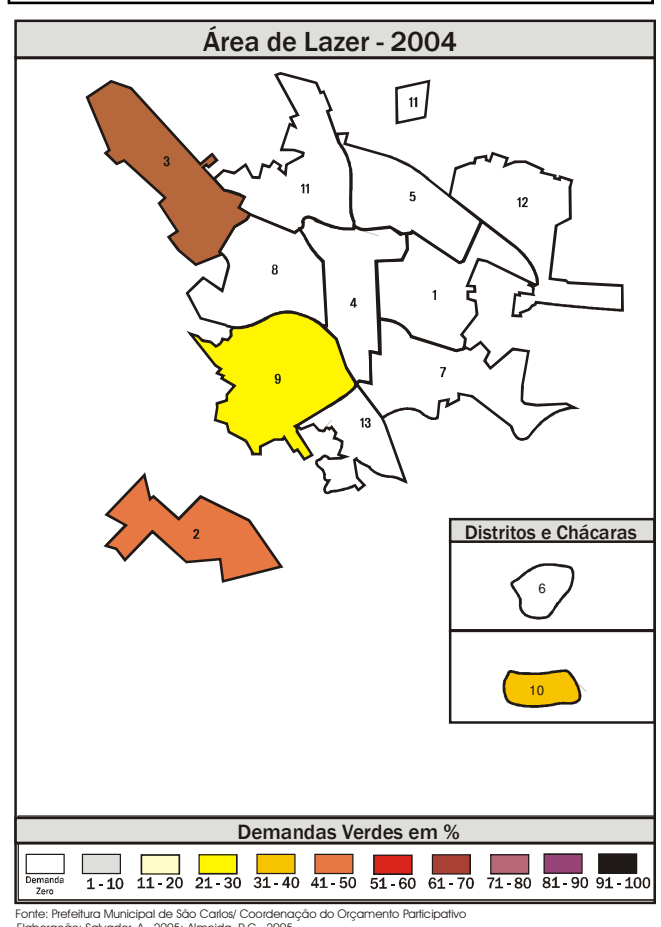


Figura 19 - Demandas das Regiões do OP por Áreas Verdes / 2002

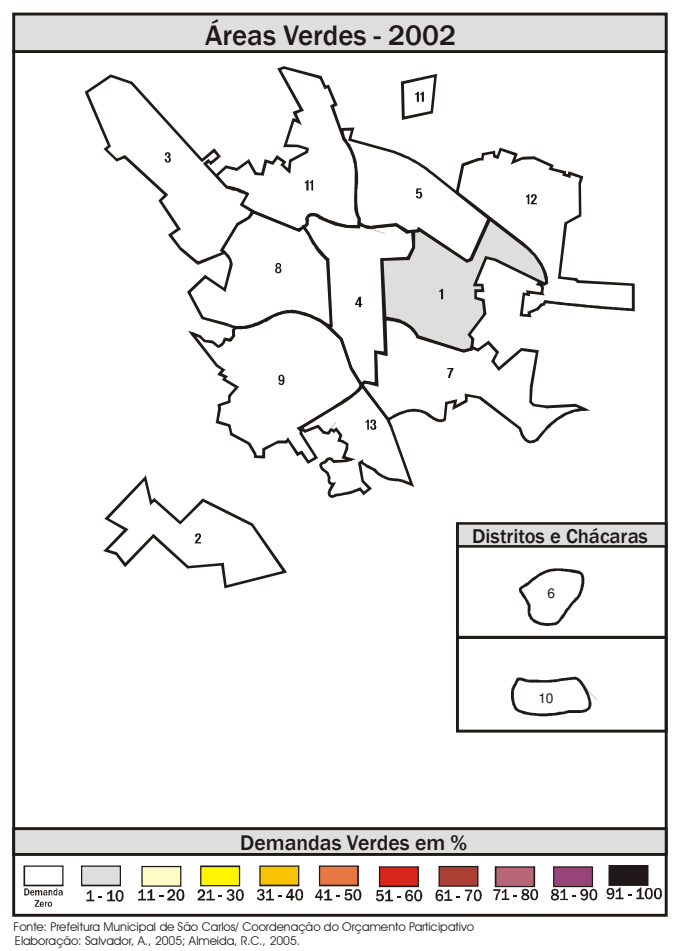

Figura 21 - Demandas das Regiões do OP por Campanhas Ambientais / 2002

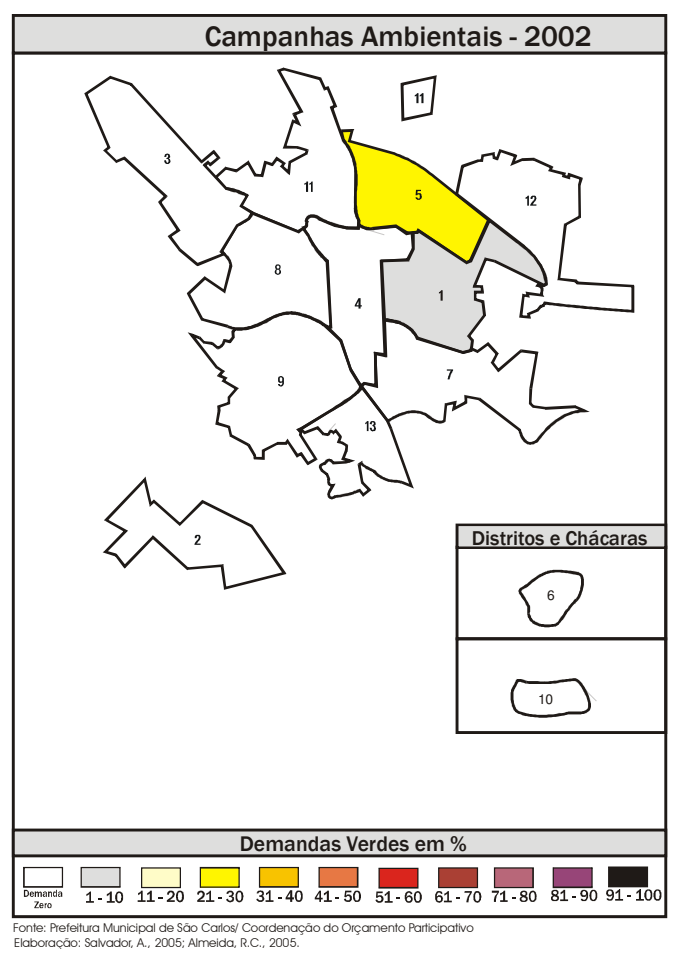

Figura 20 - Demandas das Regiões do OP por Áreas Verdes / 2003

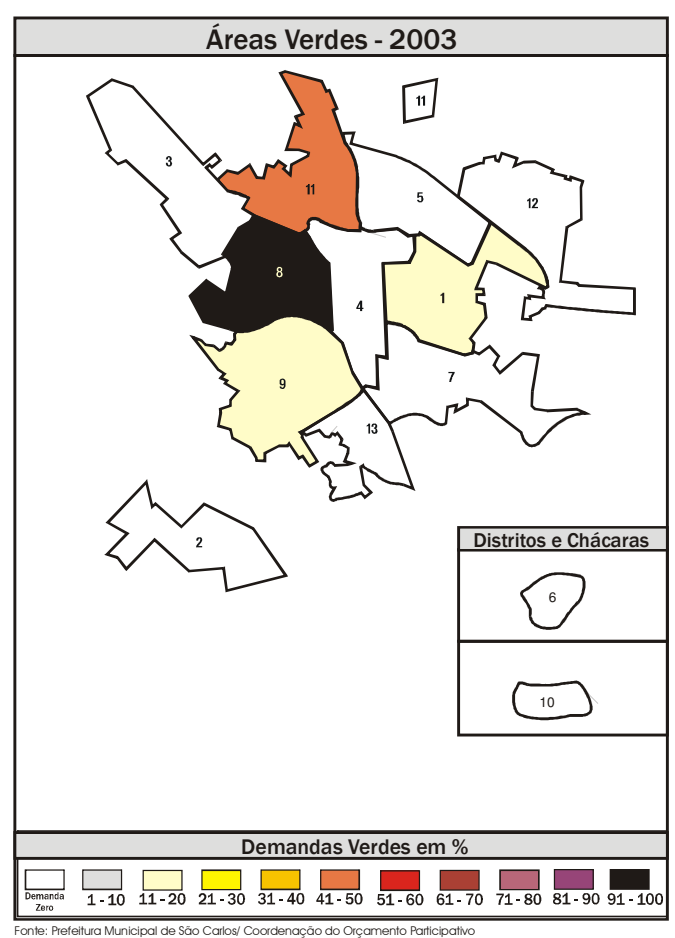

Figura 22 - Demandas das Regiões do OP por Canalização de Rio / 2001

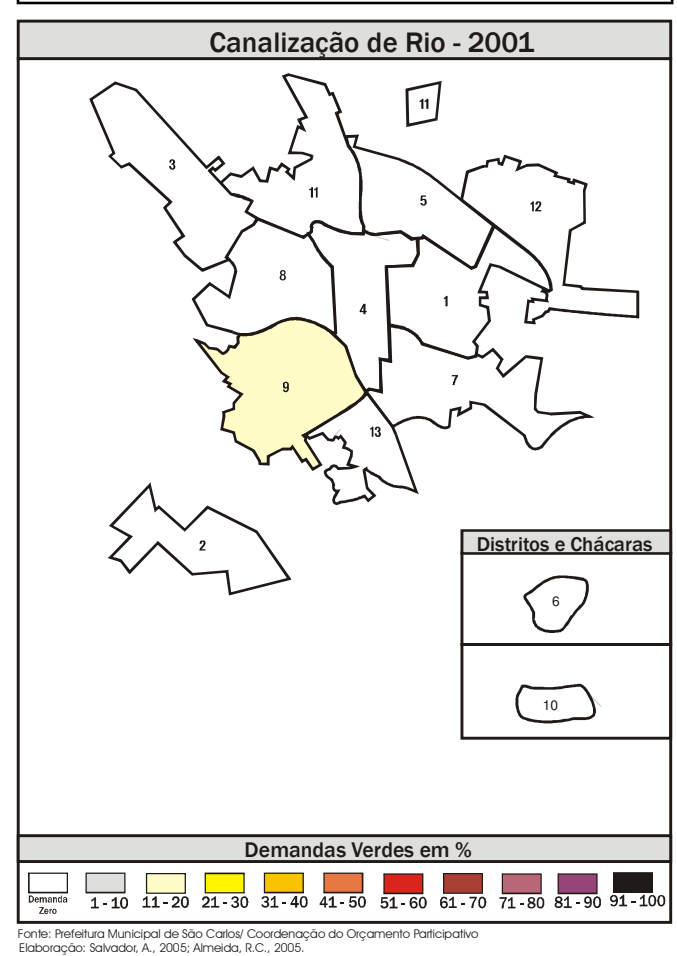


Figura 23 - Demandas das Regiões do OP por Coleta Seletiva / 2002

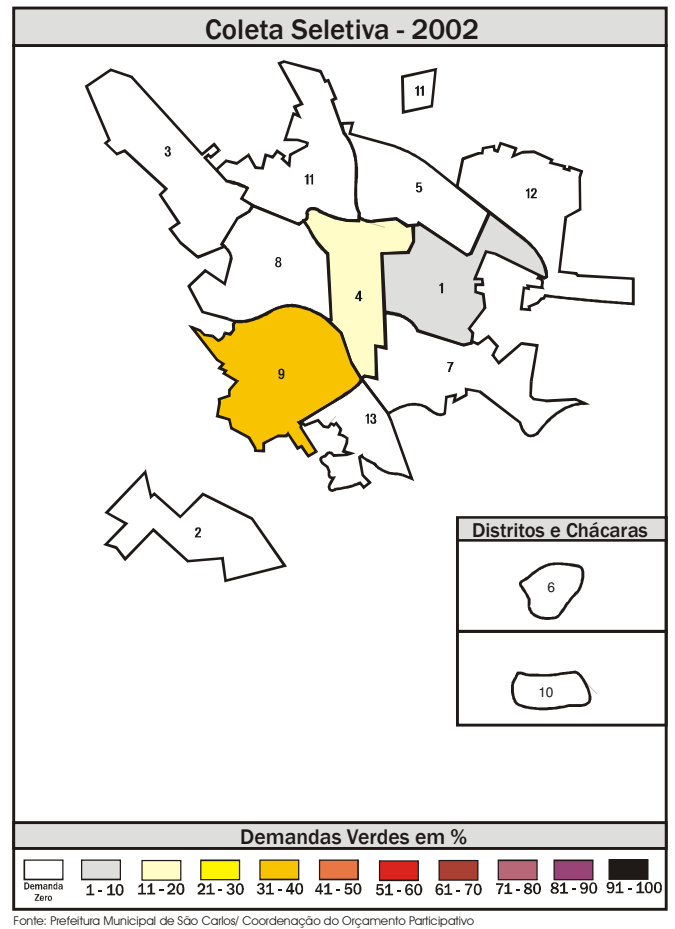

Figura 24 - Demandas das Regiões do OP por Combate a Enchentes / 2001

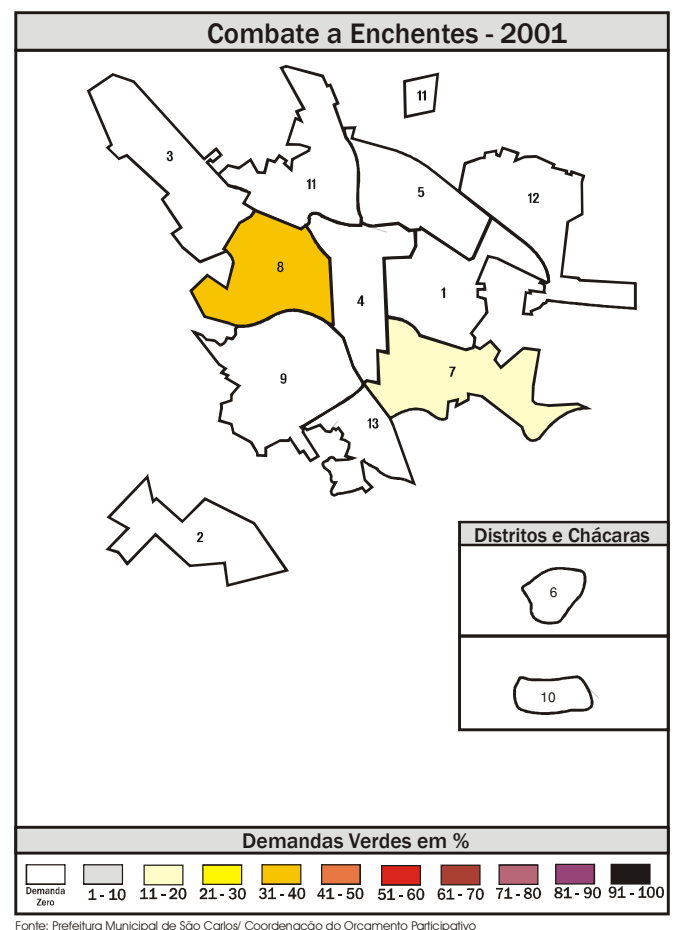

Figura 25 - Demandas das Regiões do OP por Combate a Enchentes / 2002

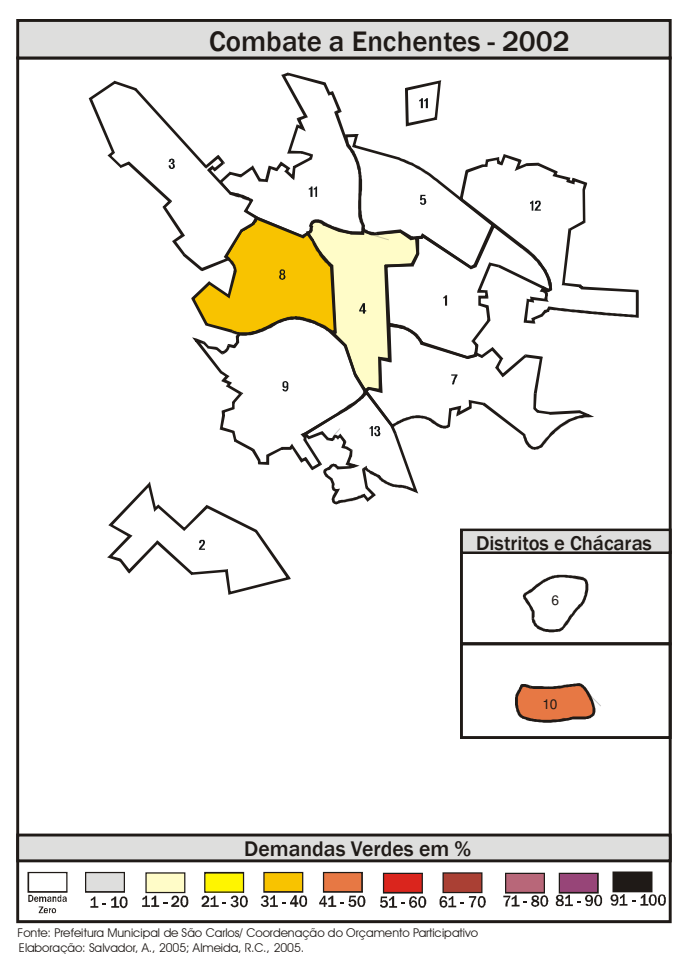


Figura 26 - Demandas das Regiões do OP por combate a Erosão / 2001

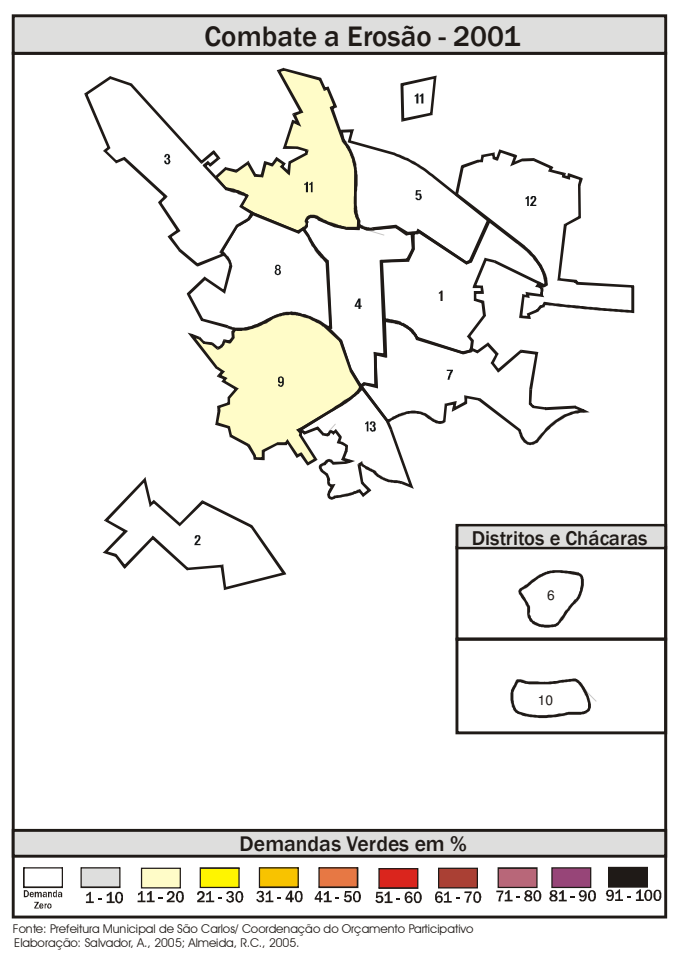

Figura 28 - Demandas das Regiões do OP por Combate a Erosão / 2003

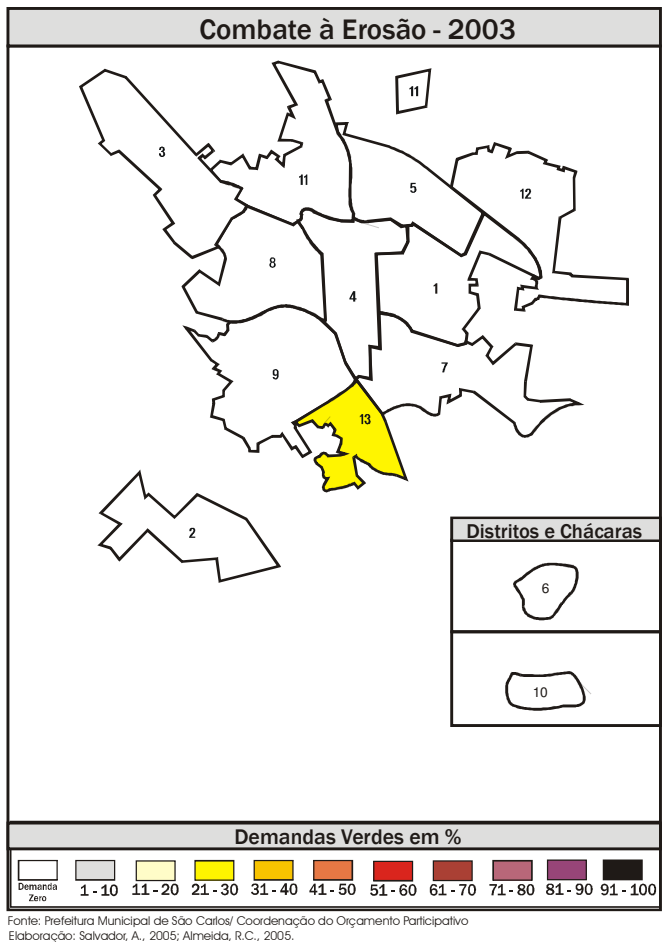

Figura 27 - Demandas das Regiões do OP por Combate a Erosão / 2002

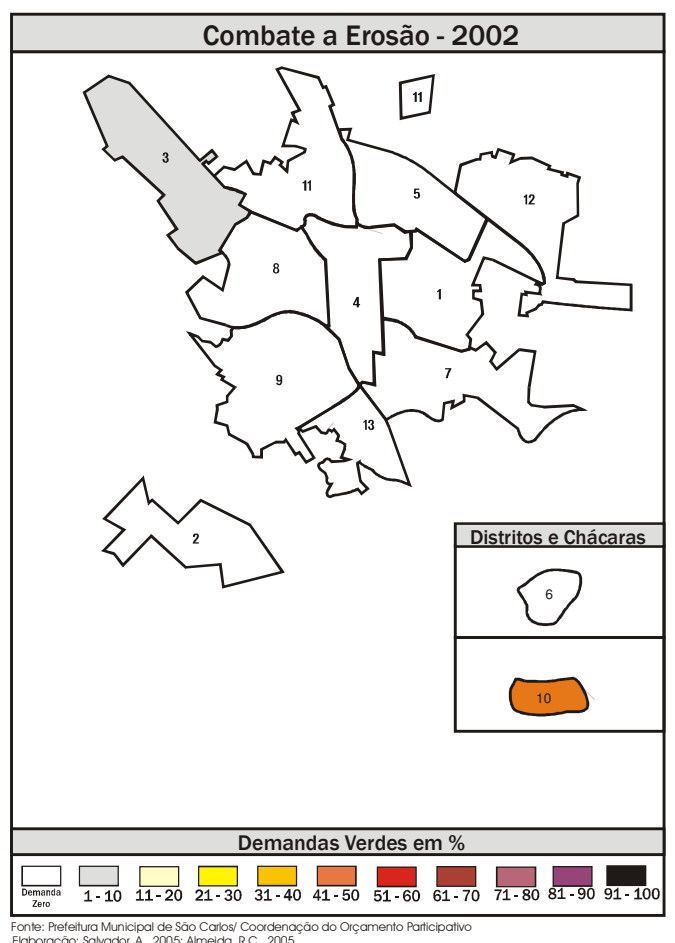

Figura 29 - Demandas das Regiões do OP por Combate a Erosão / 2004

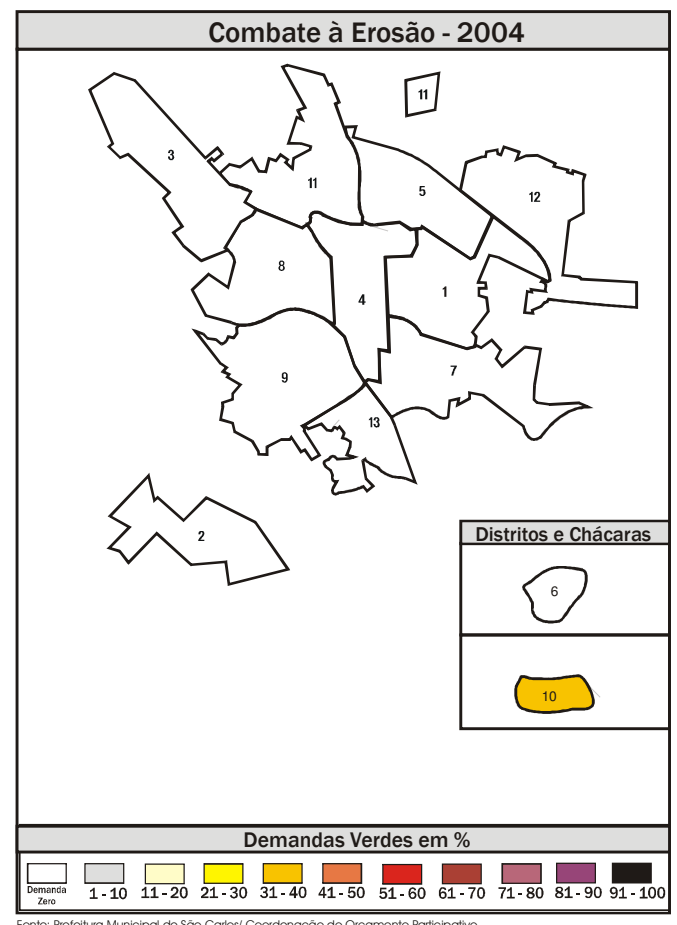


Figura 30 - Demandas das Regiões do OP por Galerias Pluviais / 2001

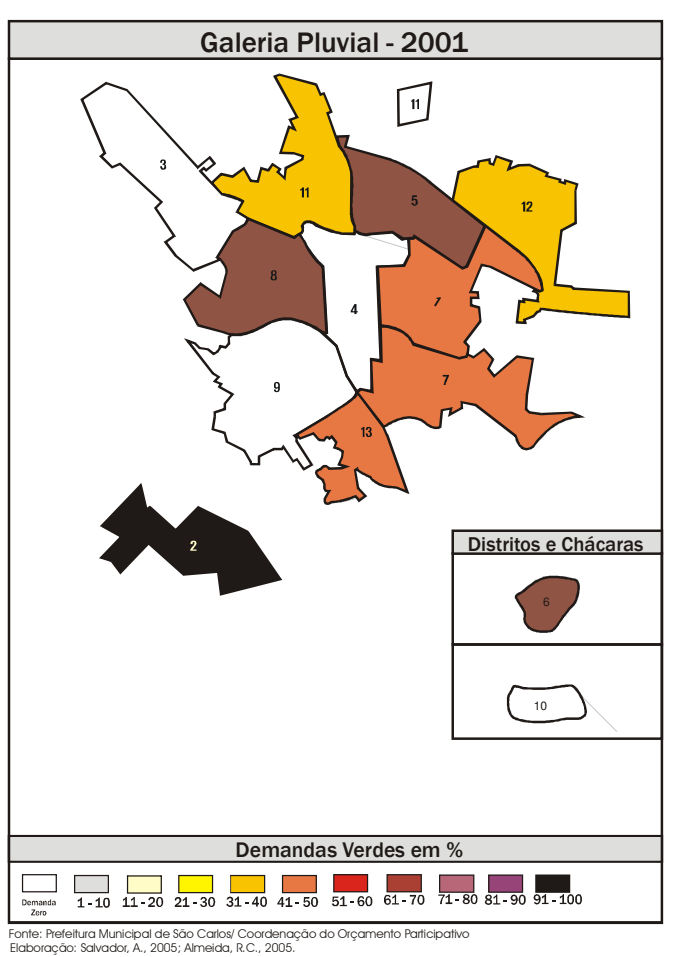

Figura 32 - Demandas das Regiões do OP por Galerias Pluviais / 2003

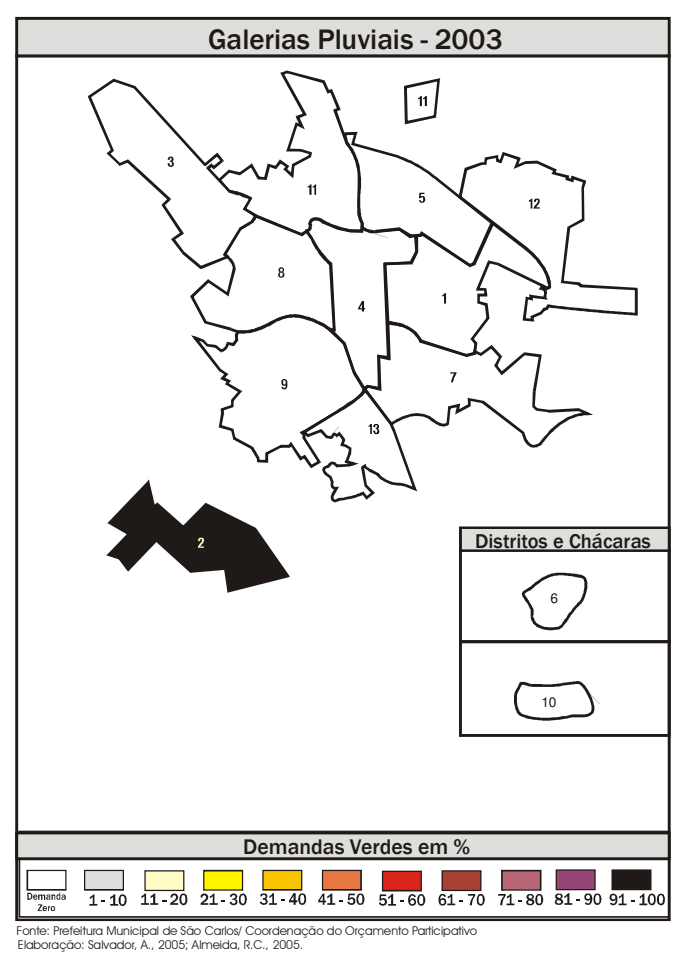

Figura 31 - Demandas das Regiões do OP por Galerias Pluviais / 2001

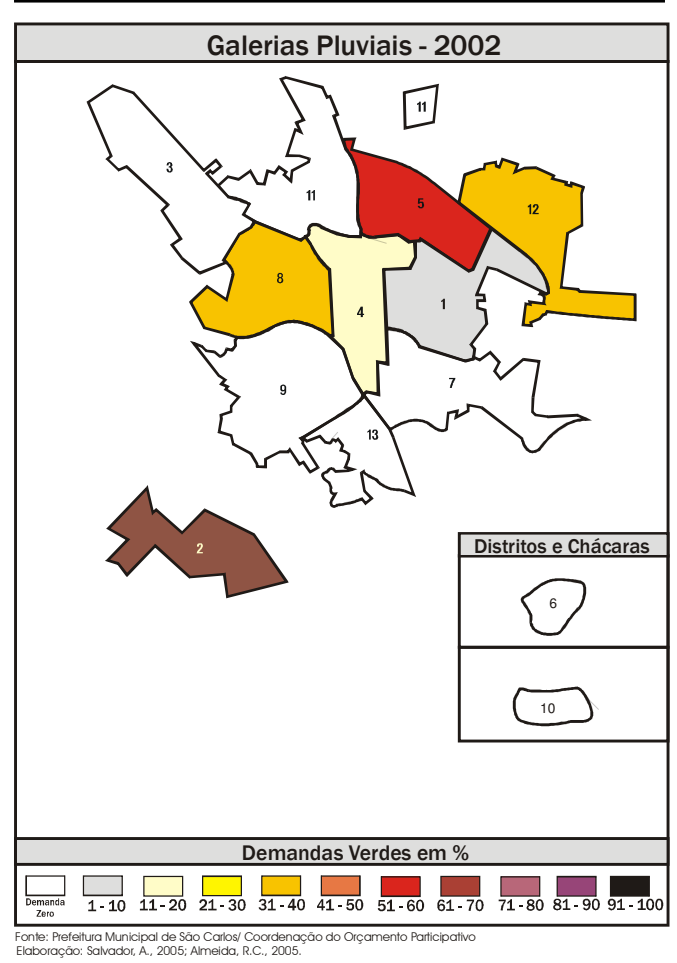

Figura 33 - Demandas das Regiões do OP por Galerias Pluviais / 2004

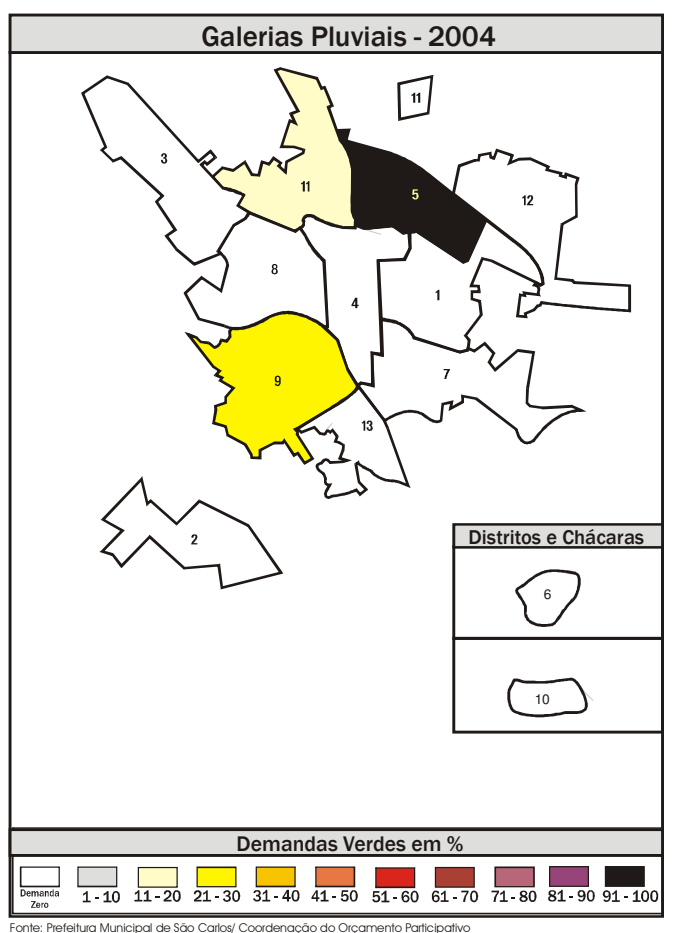


Figura 34 - Demandas das Regiões do OP por Limpeza de Rio / 2001

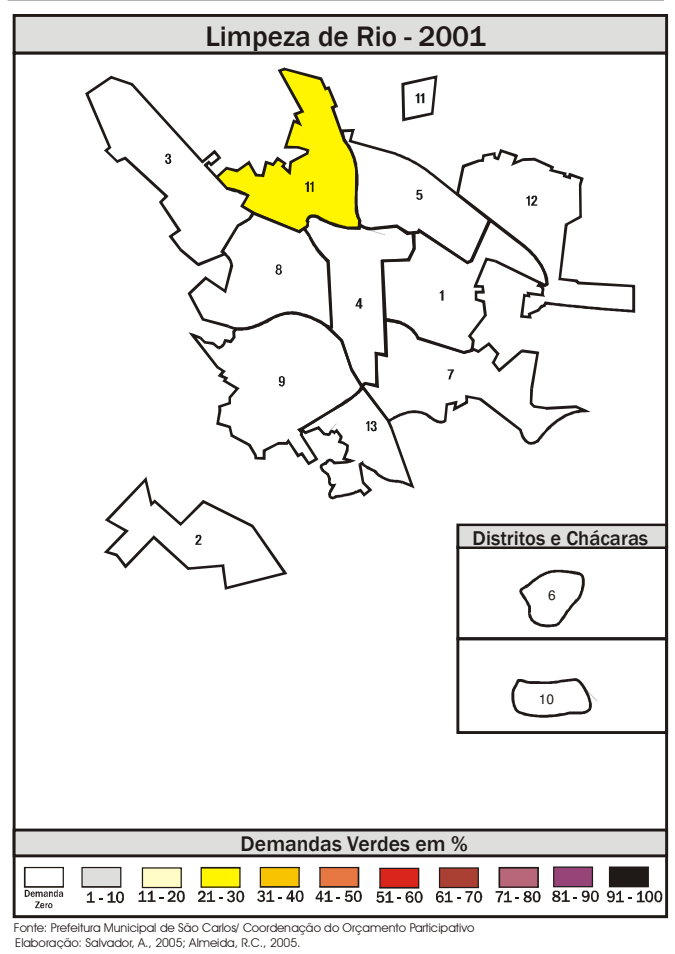

Figura 36 - Demandas das Regiões do OP por Lixeiras / 2002

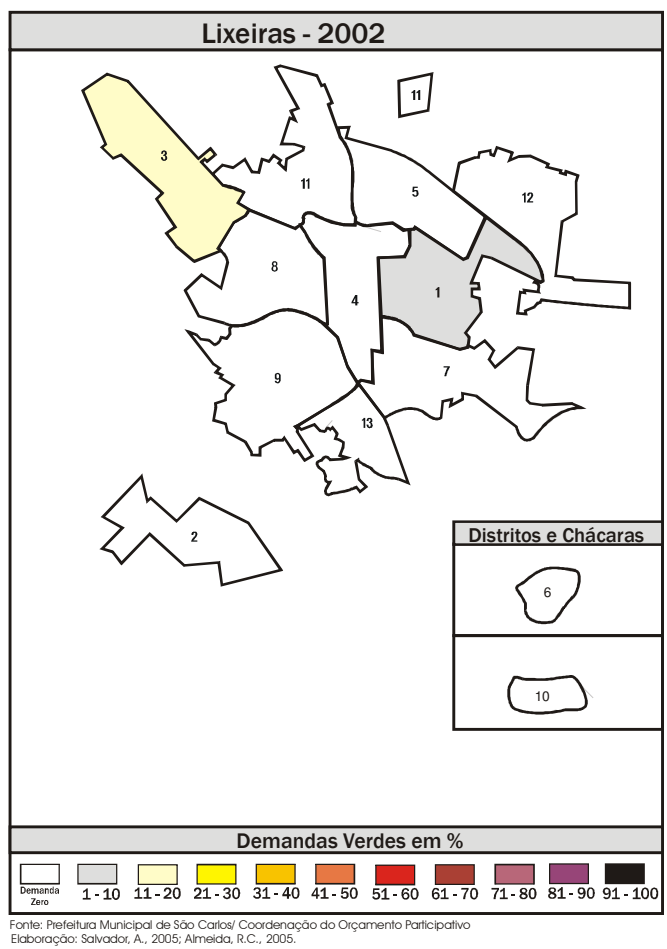

Figura 35 - Demandas das Regiões do OP por Limpeza de Rio / 2002

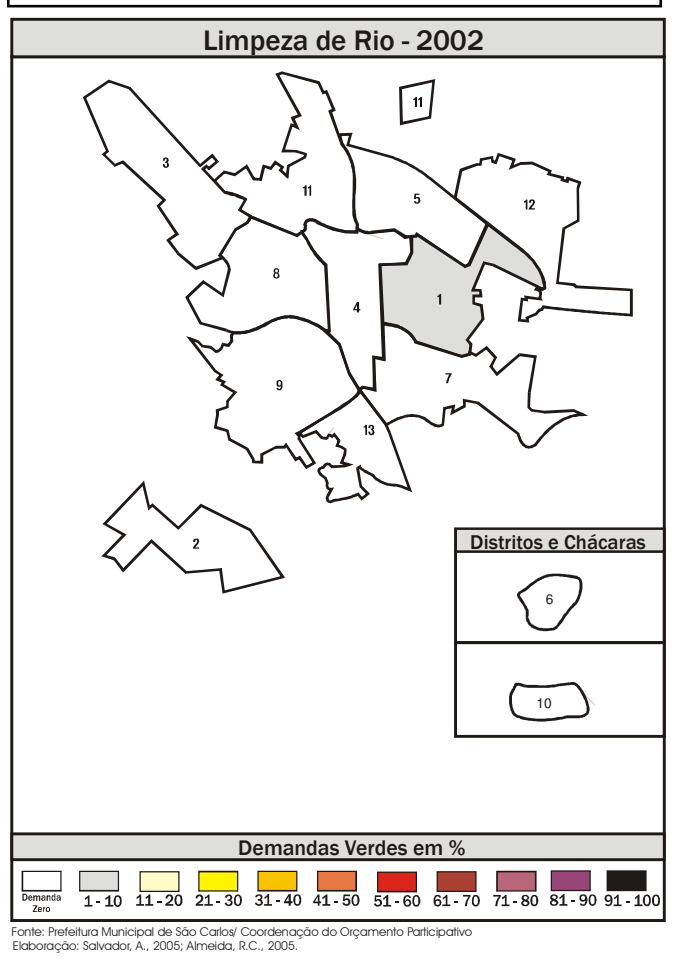


Figura 37 - Demandas das Regiões do OP por Combate a Poluição Industrial / 2002

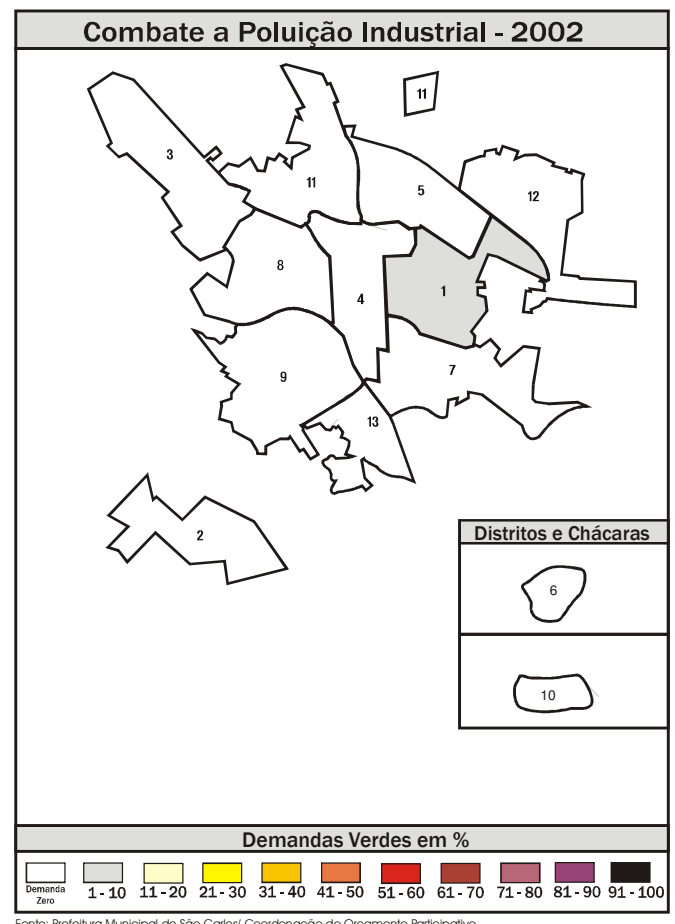

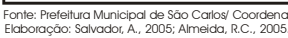

Figura 38 - Demandas das Regiões do OP por Combate a Poluição Sonora / 2002

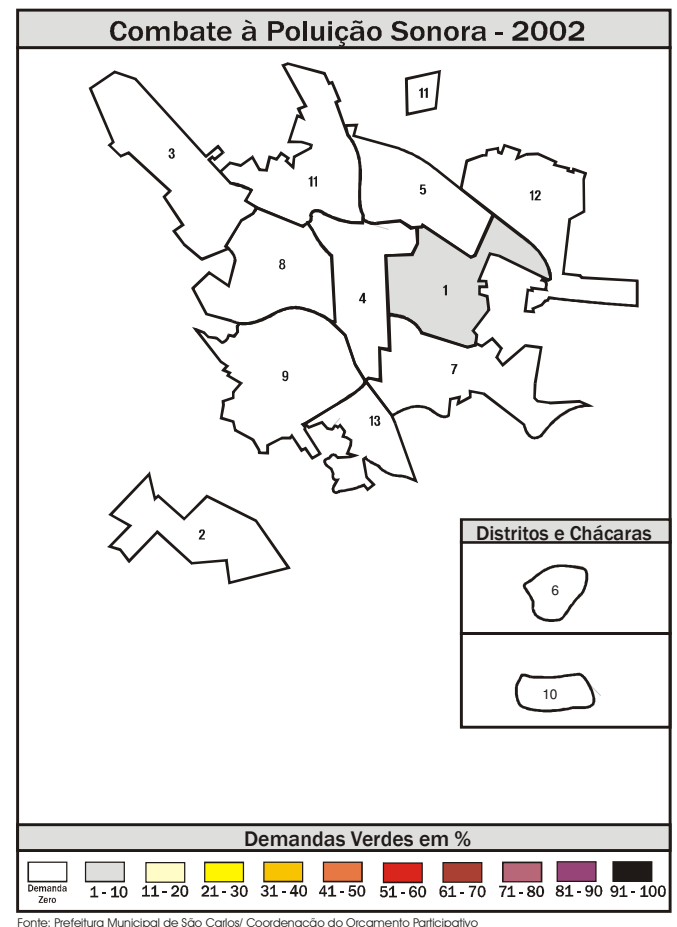


Figura 39 - Demandas das Regiões do OP por Praças / 2001

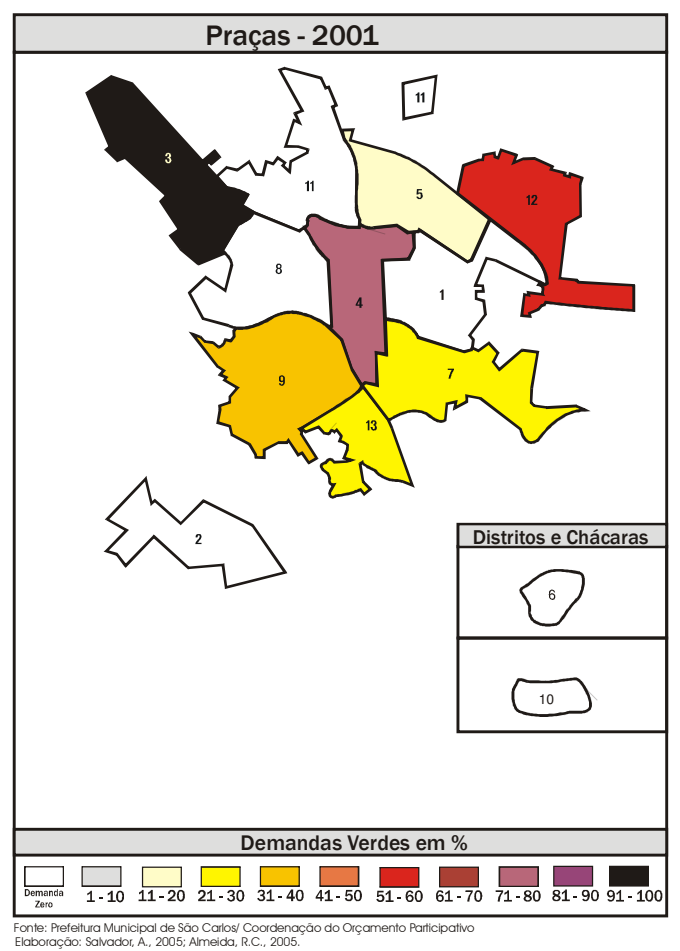

Figura 41 - Demandas das Regiões do OP por Praças / 2003

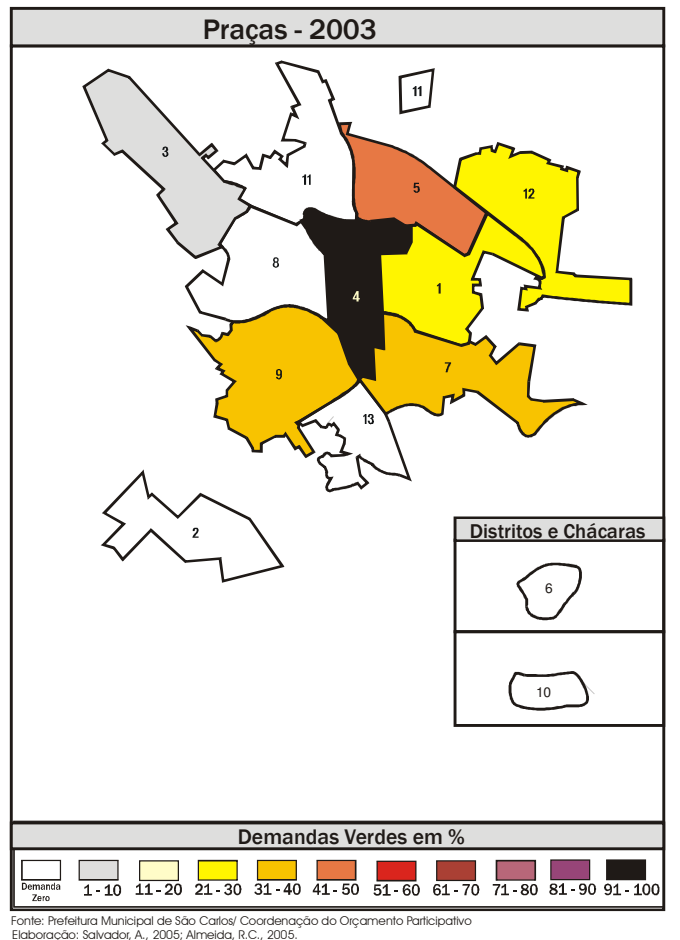

Figura 40 - Demandas das Regiões do OP por Praças / 2002

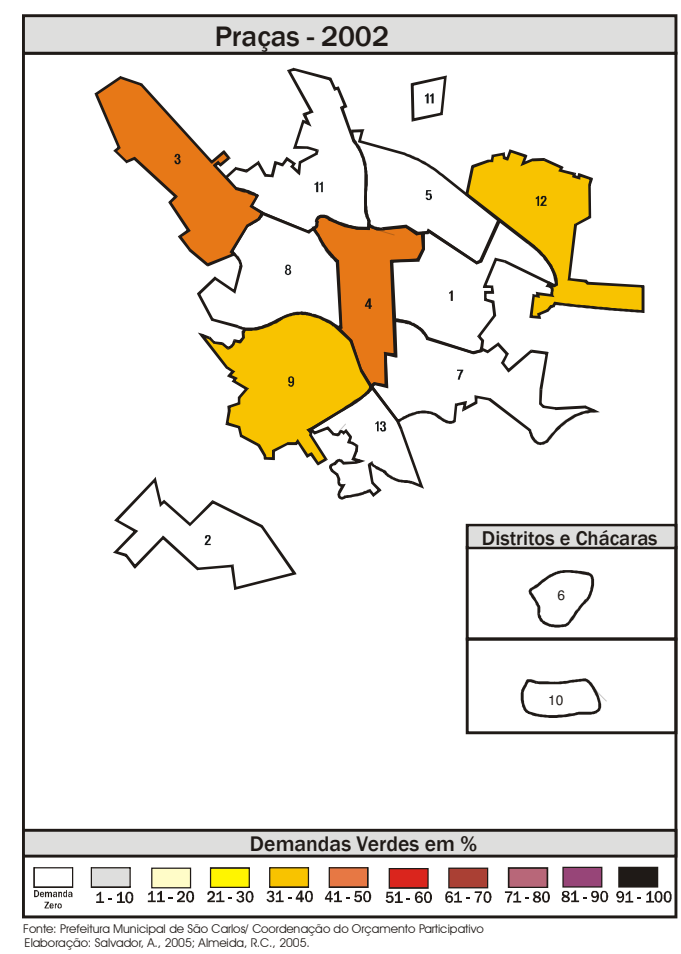

Figura 42 - Demandas das Regiões do OP por Praças / 2004

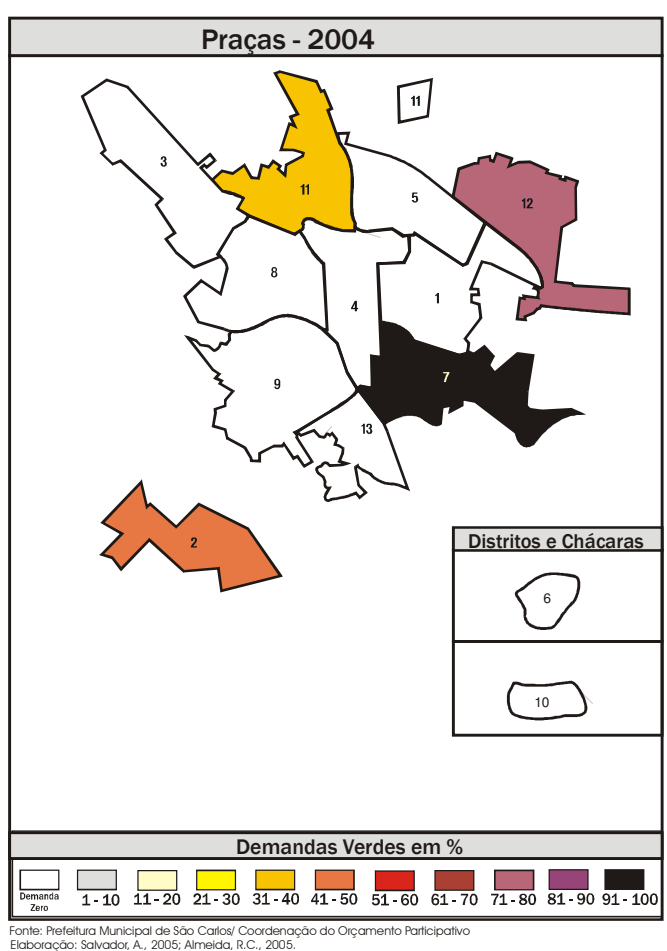


Figura 43 - Demandas das Regiões do OP por Projetos Preservação Ambiental / 2002

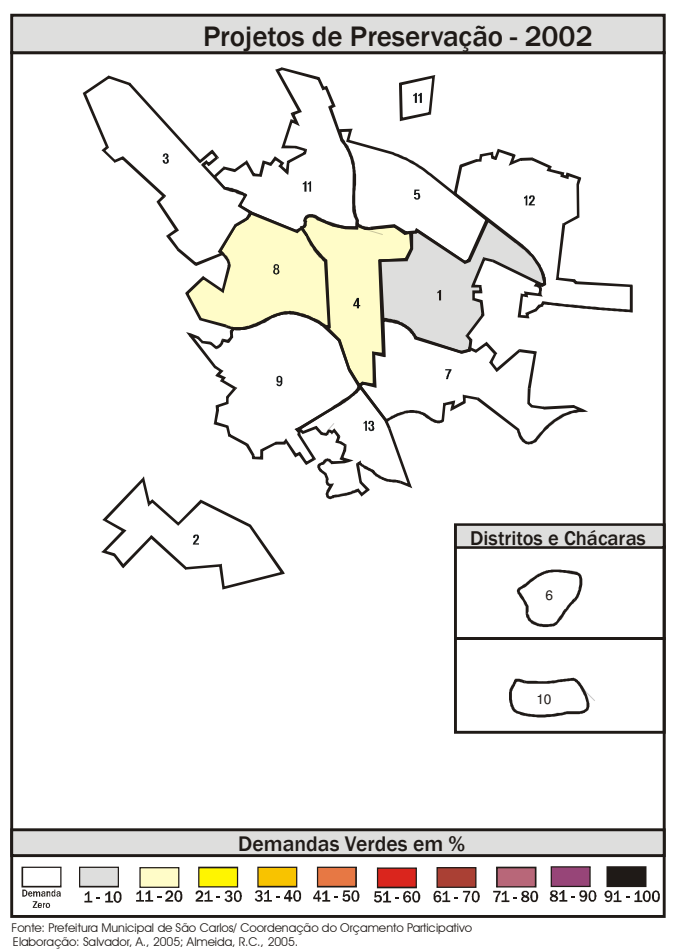

Figura 45 - Demandas das Regiões do OP por Combate a Queimadas / 2002

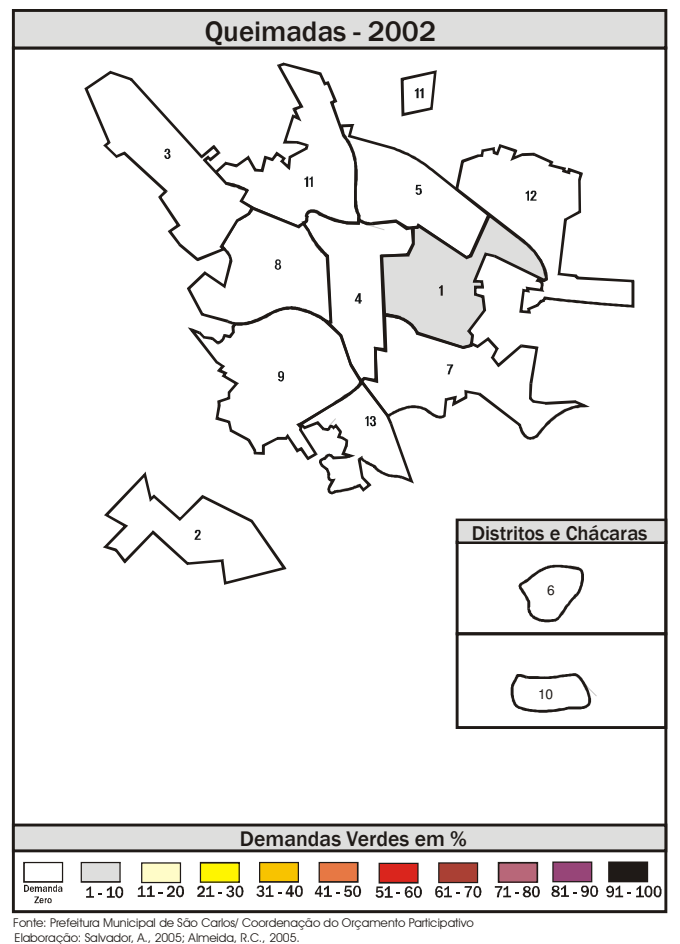

Figura 44 - Demandas das Regiões do OP por Projetos Preservação Ambiental /2003

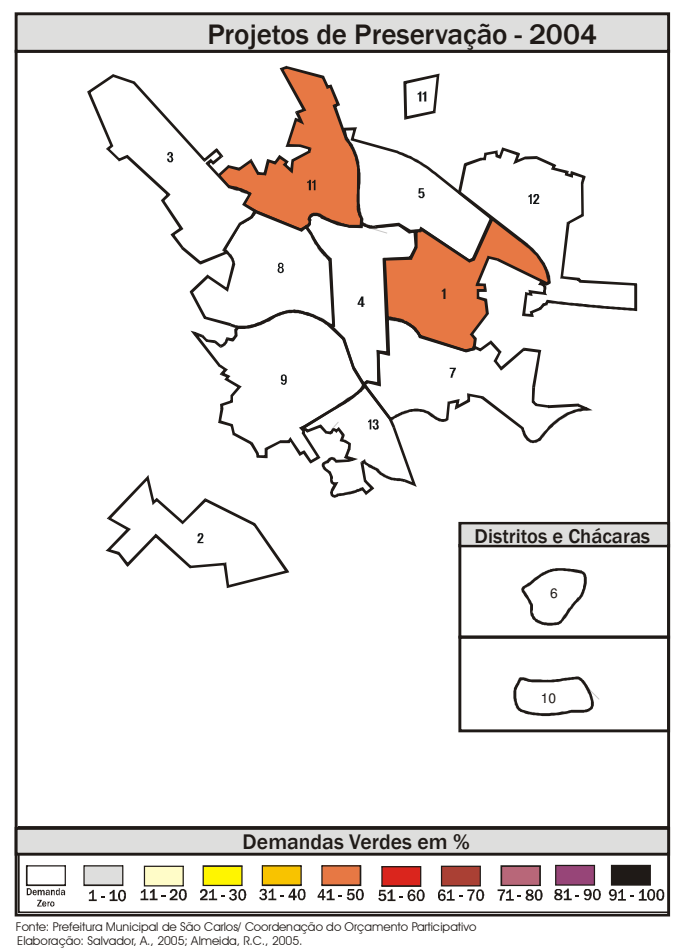

Figura 46 - Demandas das Regiões do OP por Recuperação Curso D’Água / 2004

Recuperação de Curso D'Água - 2004

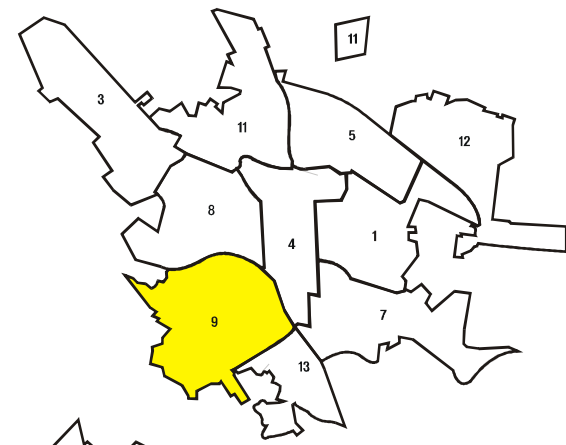<smiles>CCCCCC1CCCCCC1</smiles>

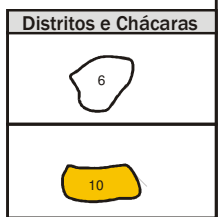


Figura 47 - Demandas das Regiões do OP por Redes de Esgoto / 2001

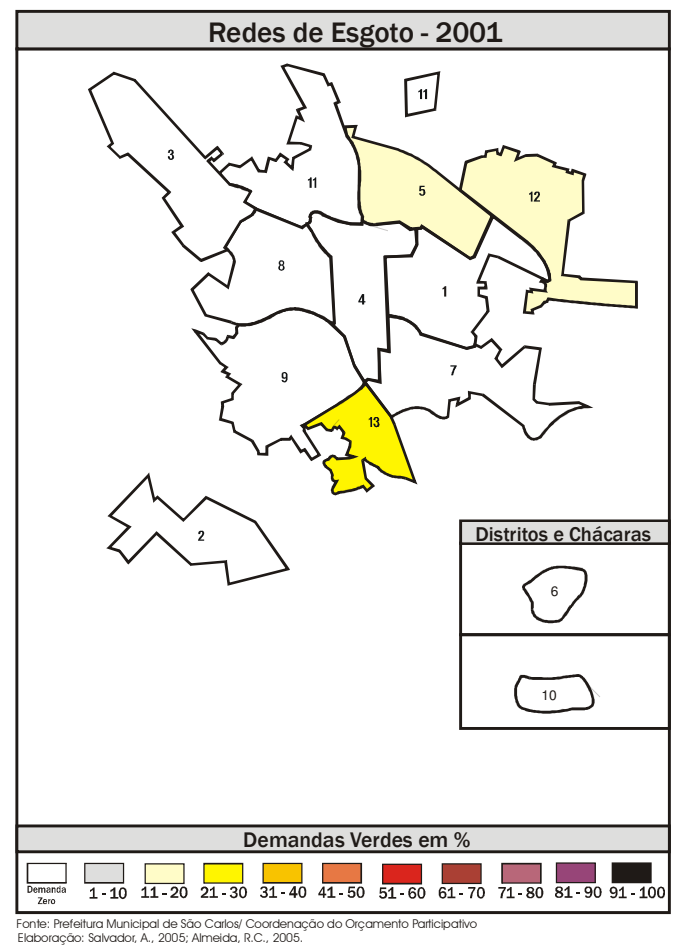

Figura 48 - Demandas das Regiões do OP por Redes de Esgoto / 2002

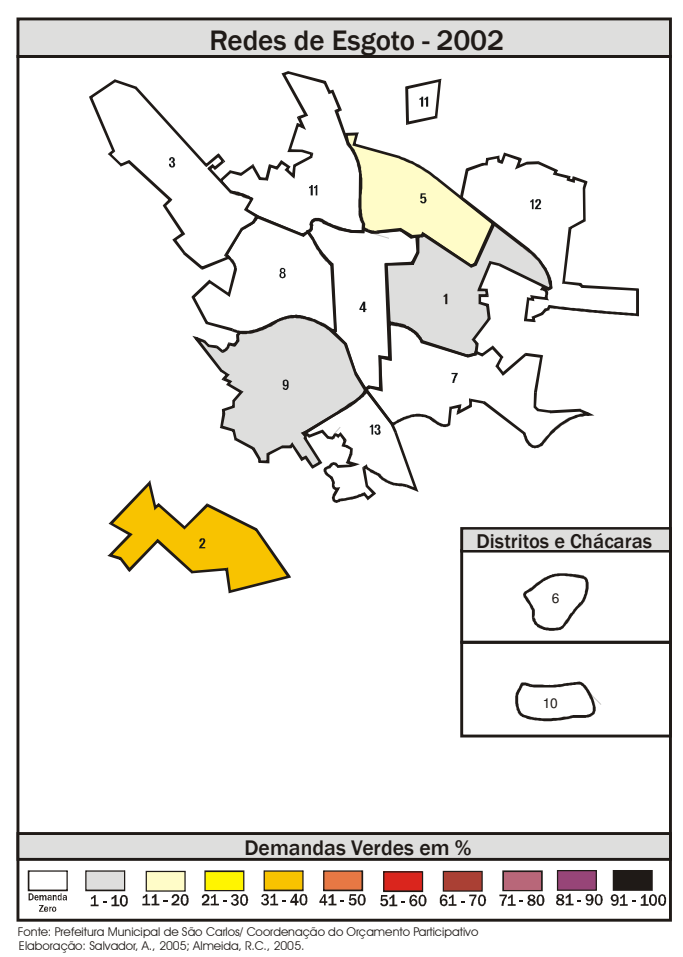

Figura 49 - Demandas das Regiões do OP por Redes de Esgoto / 2004

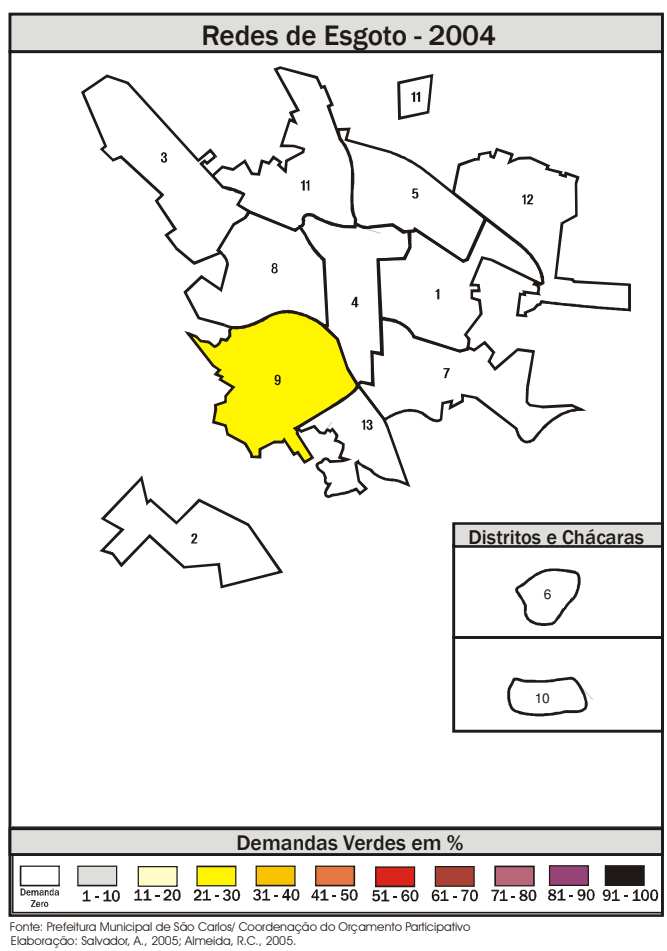


Figura 50 - Demandas das Regiões do OP por Tratamento de Esgoto / 2001

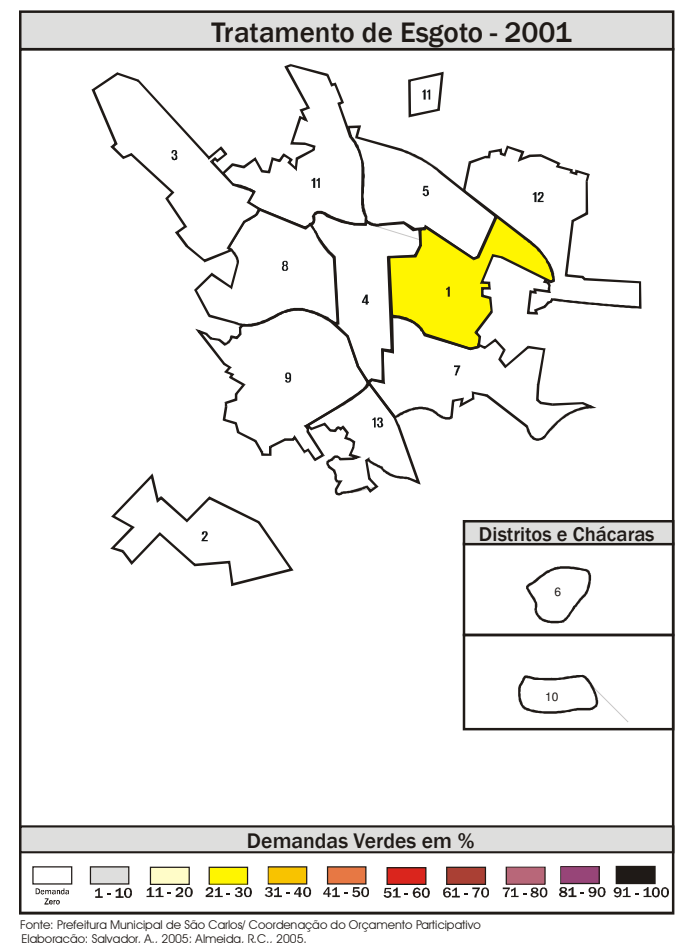

Figura 52 - Demandas das Regiões do OP por Estação Coletora / Usina Reciclagem / 2004

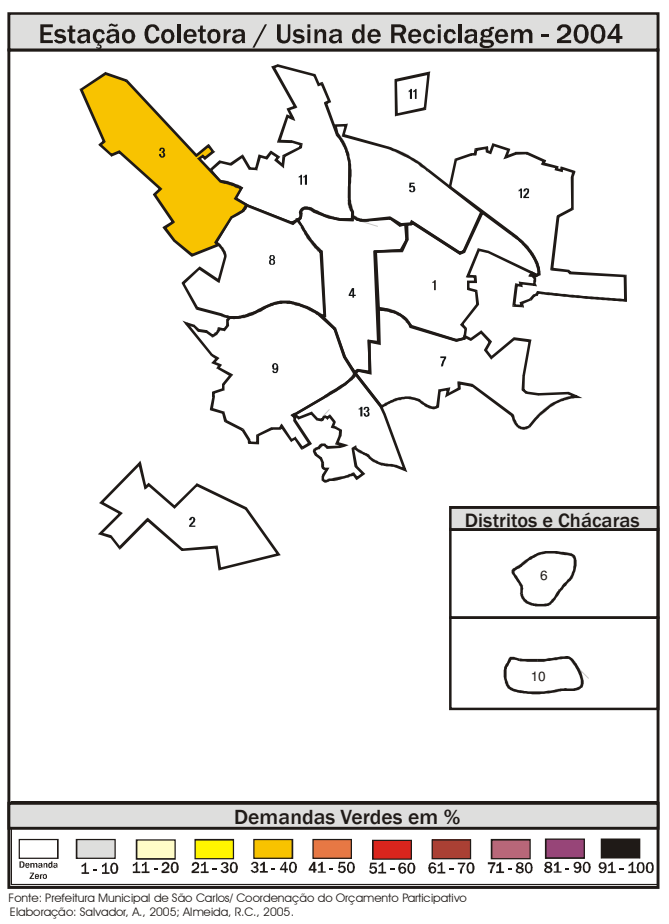

Figura 51 - Demandas das Regiões do OP por Tratamento de Esgoto / 2002

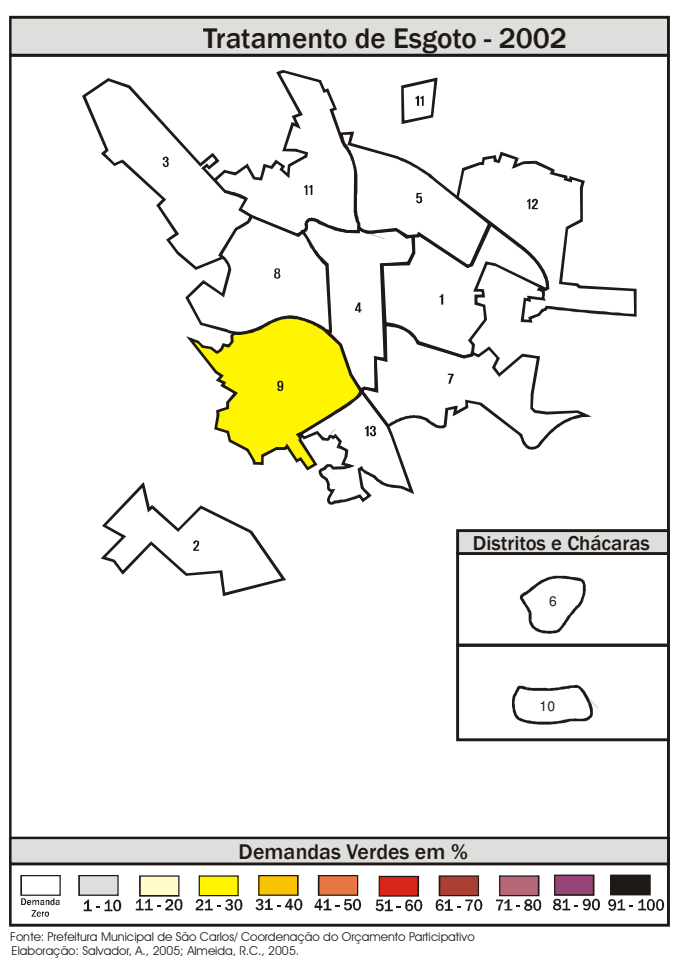




\subsection{As intervenções dos participantes do OP/SC nas micro-bacias hidrográficas}

Por conta das considerações tecidas até aqui sobre o papel que os espaços públicos deliberativos podem desempenhar nas possíveis intervenções planejadas pelo poder público municipal, principalmente aquelas relacionadas aos cursos d'água do município, destacamos seis micro-bacias que sofrem uma das graves causas desses impactos negativos - as enchentes. A nosso ver, os moradores das regiões de influência nessas micro-bacias podem, através das Assembléias do OP, propor ações e/ou intervenções a fim de minimizar ou resolver esse grave problema. São elas: as micro-bacias dos Córregos do Gregório; do Lazarini; do Mineirinho; do Santa Maria do Leme; do Sorregotti e do Tijuco Preto (Figura $53)$.

Primeiramente, é importante a descrição físico-ambiental do Rio do Monjolinho (Figuras 54 e 55), o principal curso d'água do município e que dá nome a sua bacia hidrográfica. A Bacia Hidrográfica do Rio do Monjolinho (Figura 53) abrange uma área de aproximadamente $275 \mathrm{Km}^{2}$, sendo a maior parcela no município de São Carlos e com uma parcela menor no município vizinho de Ibaté. Com uma extensão de aproximadamente 43,25 Km, o rio do Monjolinho nasce no planalto de São Carlos, a leste do município, na cota de 900m, percorrendo o sentido leste-oeste. Recebe contribuições de vários afluentes, como os das micro-bacias dos Córregos do Gregório; do Lazarini; do Mineirinho; do Santa Maria do Leme; do Sorregoti e do Tijuco Preto. Além das águas de seus afluentes, o Rio do Monjolinho também recebe águas residuais formadas por esgotos sanitários e despejos industriais. Já na área para além do urbano, ao encontrar o substrato basáltico, adquire aspecto encachoeirado que conserva até sua desembocadura no Rio Jacaré-Guaçu, na cota de 543m, representando um desnível de 357 metros em relação a sua nascente (ESPÍNDOLA, 2000).

MARINELLI (2000) aponta que a qualidade da água no Rio do Monjolinho apresenta um gradiente decrescente de qualidade da nascente em direção a sua desembocadura e essa degradação torna o padrão de qualidade de suas águas inaceitável para o consumo humano, com destaque ao impacto causado pelo despejo de esgotos domésticos, crescentes no 
sentido montante-jusante. Assim, observamos que o lançamento de efluentes domésticos e industriais, reflexo do processo de urbanização do município e do não tratamento desses efluentes, é a principal função de força que determina as condições dessas águas. Todavia, outros fatores como desmatamento, expansão de atividades agrícolas, particularmente a cana de açúcar e a urbanização em sua área de entorno também contribuíram para a deterioração do sistema. 
Figura 53 - Micro-Bacias Urbanas - Bacia Hidrográfica do Rio do Monjolinho

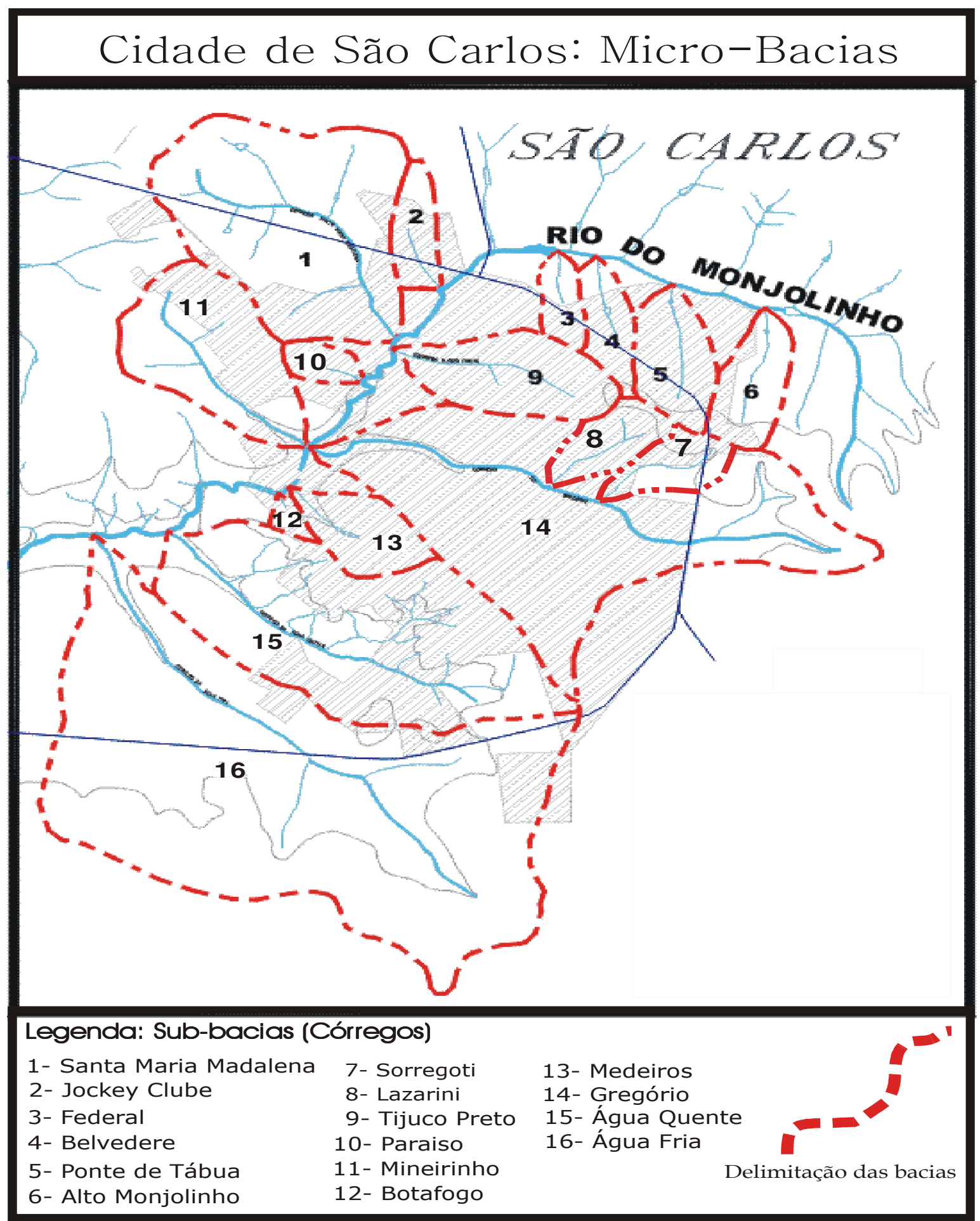

Fonte: CDCC/USP/ São Carlos 


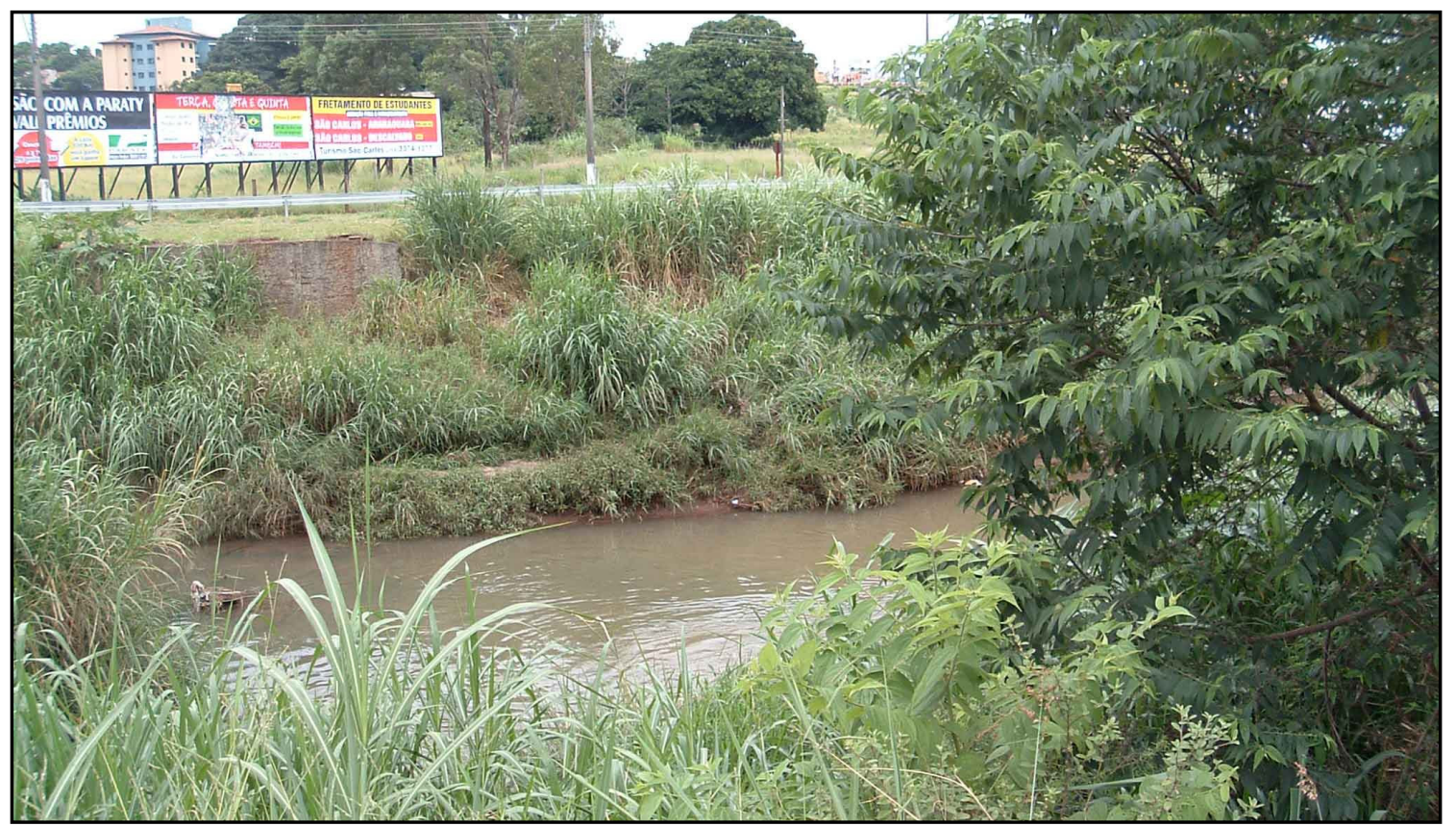

Fonte: Almeida, 2005

Figura 54 - Rio do Monjolinho - Região 08 - Avenida Marginal, área de ocorrência de enchentes.

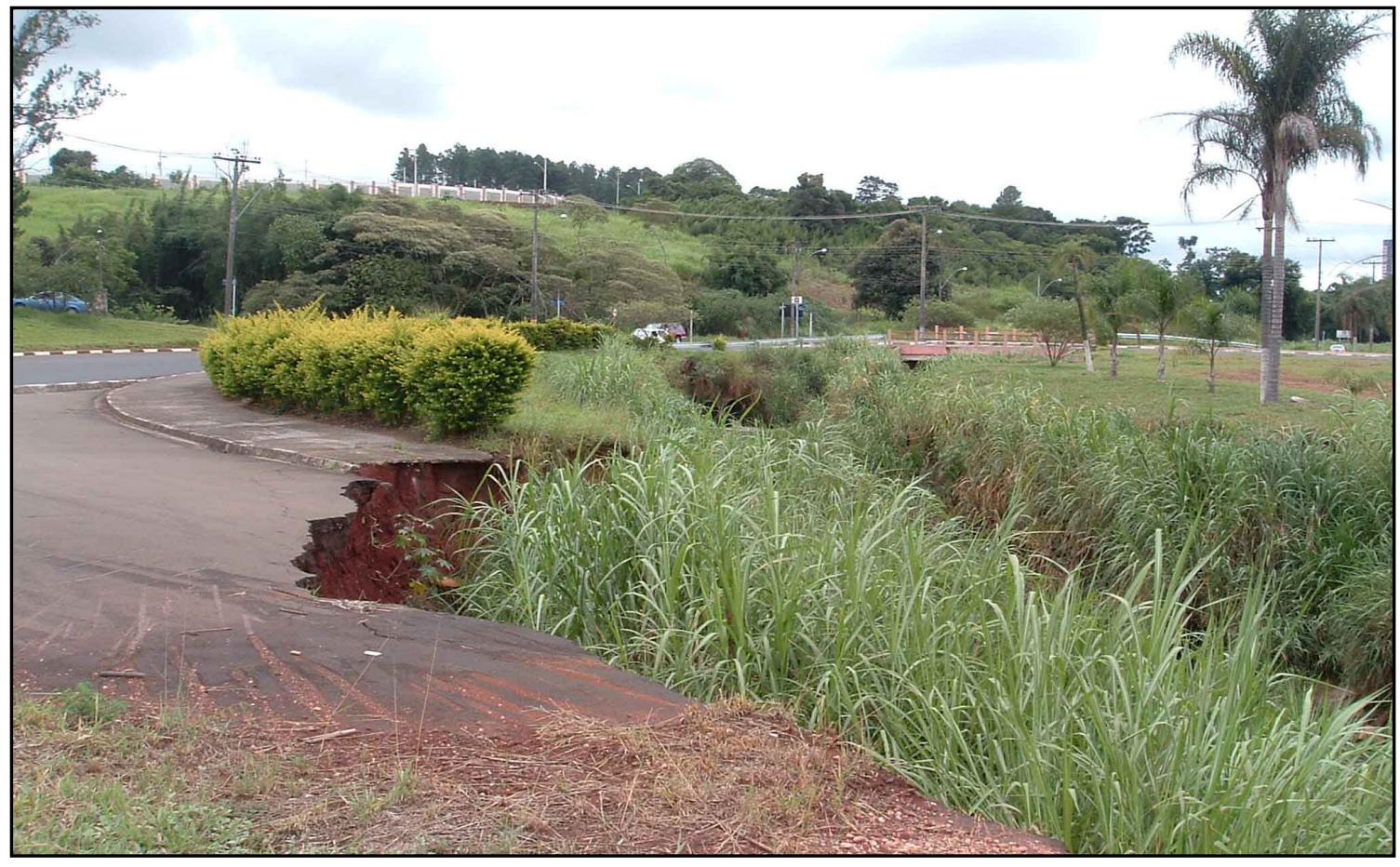

Figura 55 - Rio do Monjolinho - Região 08 - Avenida Marginal, área de ocorrência de enchentes. 


\subsubsection{Micro-bacia do córrego do Sorregoti (Figura 53)}

A nascente do córrego do Sorregoti (Figura 56) localiza-se nos limites entre as regiões 01 e 12, percorre a região 01 e desemboca no córrego do Gregório, na área da marginal.

\subsubsection{Micro-bacia do córrego do Lazarini (Figura 53)}

O córrego do Lazarini (Figura 57) nasce e percorre a região 01, desembocando no córrego do Gregório, na região 04, na área da marginal.

Essas duas micro-bacias influem diretamente na qualidade e quantidade das águas do Córrego do Gregório (Figuras 58 e 59) que percorre a região 04, a que mais sofre com as enchentes. Os bairros que compõem as regiões 01 e 12 estão geograficamente localizados acima dos bairros da região 04, todos com uma grande área impermeabilizada, com os córregos totalmente descaracterizados, em parte canalizados sofrendo com os impactos urbanos negativos e com a ausência das matas ciliares (Figuras 56 a 59) e, como podemos comprovar através das demandas requeridas pelos seus moradores, carentes também de áreas verdes, praças e arborização urbana. Com relação a enchentes, a implantação dessas áreas verdes contribuiria para a melhor infiltração da água das chuvas, diminuindo sua quantidade e velocidade. Entretanto, os citadinos desses bairros (regiões 01 e 12) cujas ações contribuem para o agravamento das enchentes, aliadas as do poder público e da iniciativa privada exemplificada pelos empreendimentos imobiliários, não sentem o seu efeito negativo, por isso, suas demandas não estão diretamente associadas à resolução desse problema. Já a região 04 é diretamente afetada pelos impactos negativos causados a esses cursos d'água, que são afluentes do Córrego do Gregório onde as enchentes alcançam maiores proporções.

Ressaltamos, também, que a origem do núcleo urbano do município foi a partir do Córrego do Gregório. Assim, a região 04 sofre com esse impacto negativo há muito tempo. A urbanização do entorno desse córrego ocorreu sem nenhuma preocupação quanto à conservação de sua mata ciliar, com a ocupação de sua área de várzea, a canalização de grande parte desse curso d'água, a existência de poucas áreas verdes e a total impermeabilização do solo. A conjunção desses fatores aumenta o risco de enchentes, conseqüentemente essa é a região da cidade que mais sofre com esse problema. 


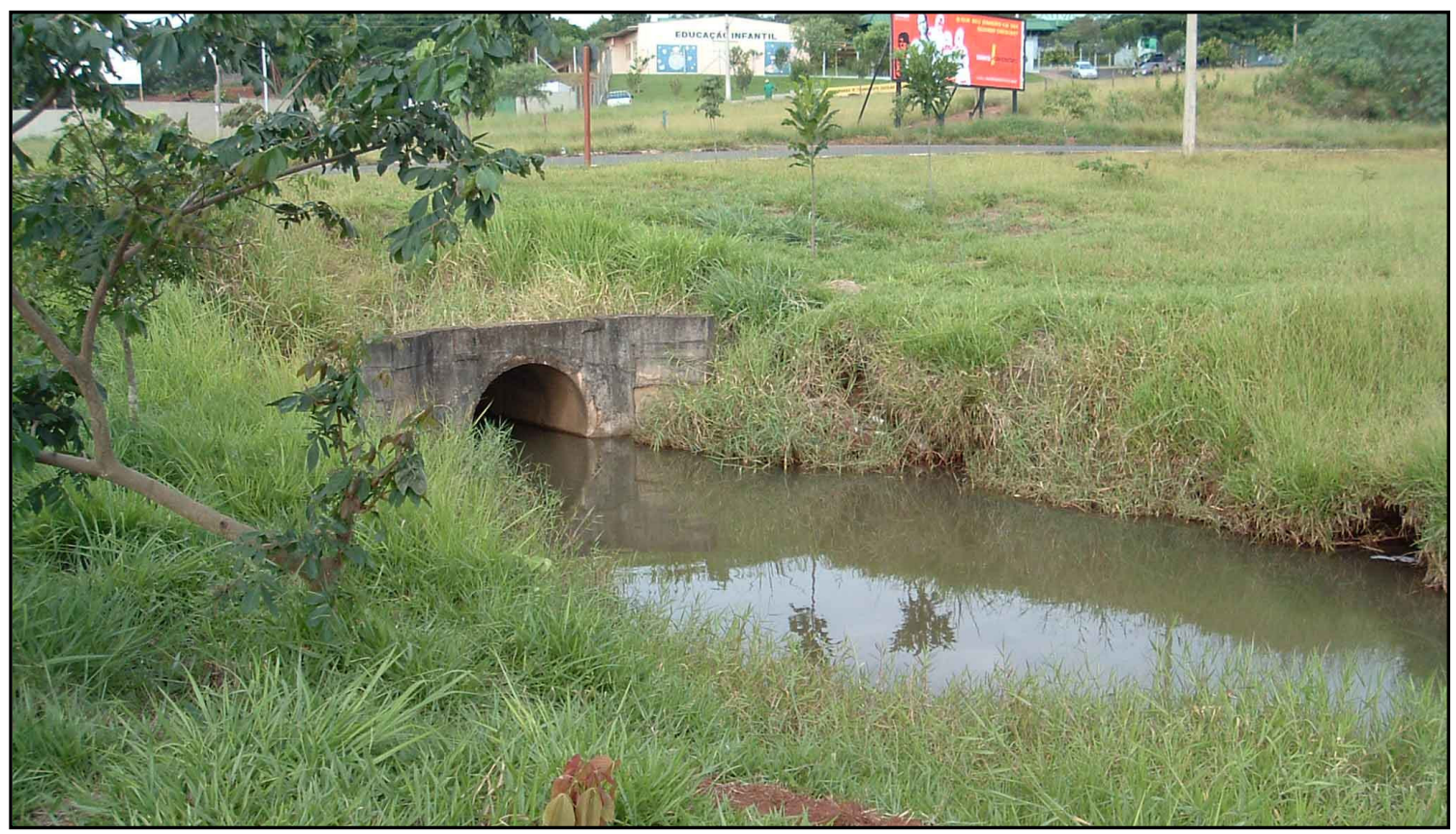

Fonte: Almeida, 2005

Figura 56 - Córrego do Sorregoti - Região 01 - Avenida Marginal, desembocadura no Córrego do Gregório.

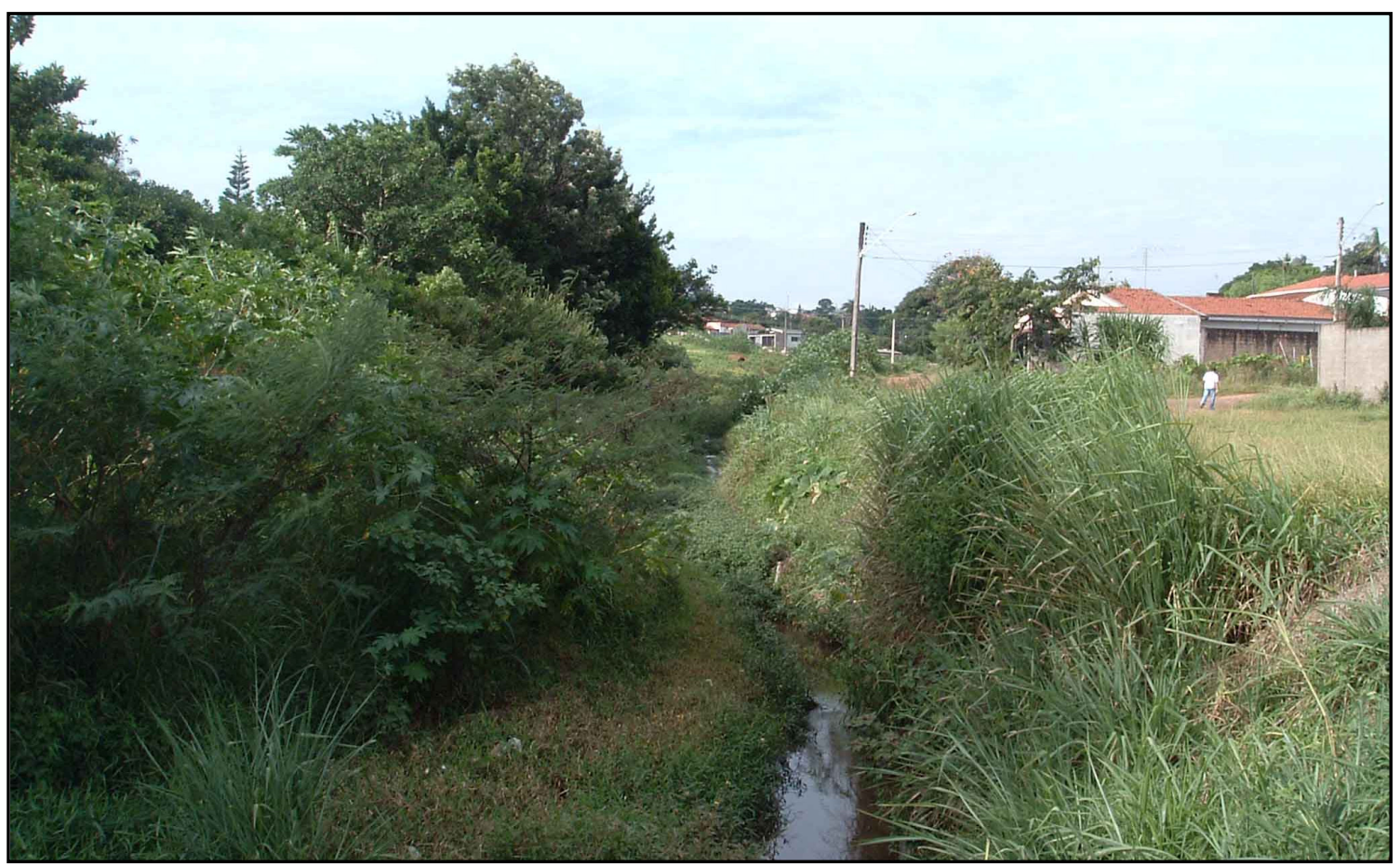

Fonte: Almeida, 2005

Figura 57 - Córrego do Lazarini - Região 04 - Avenida Marginal, próximo à desembocadura do Córrego do Gregório. 


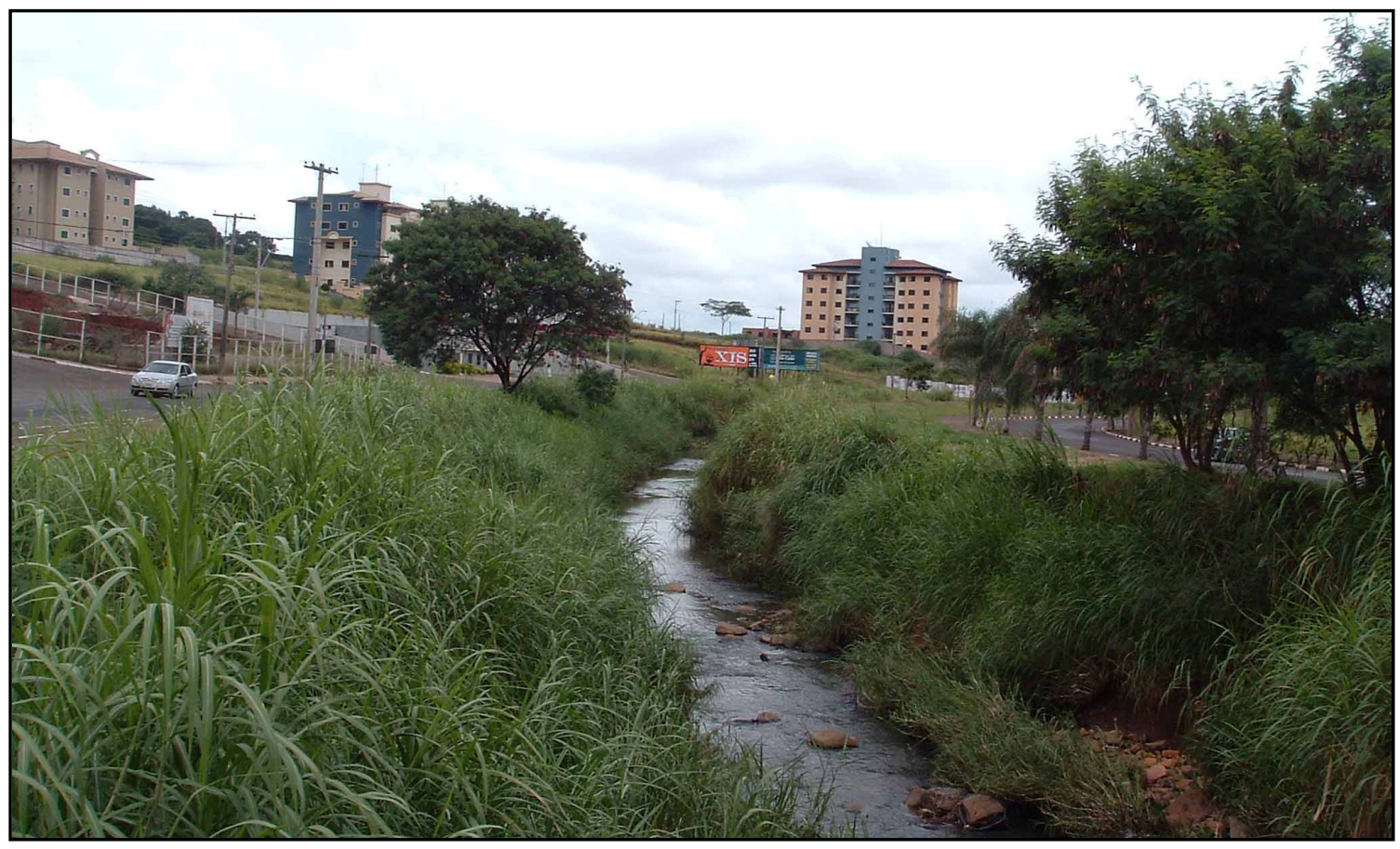

Fonte: Almeida, 2005

Figura 58 - Córrego do Gregório - Região 04 - Avenida Marginal, região próxima à desembocadura no Rio do Monjolinho, grande incidência de enchentes.

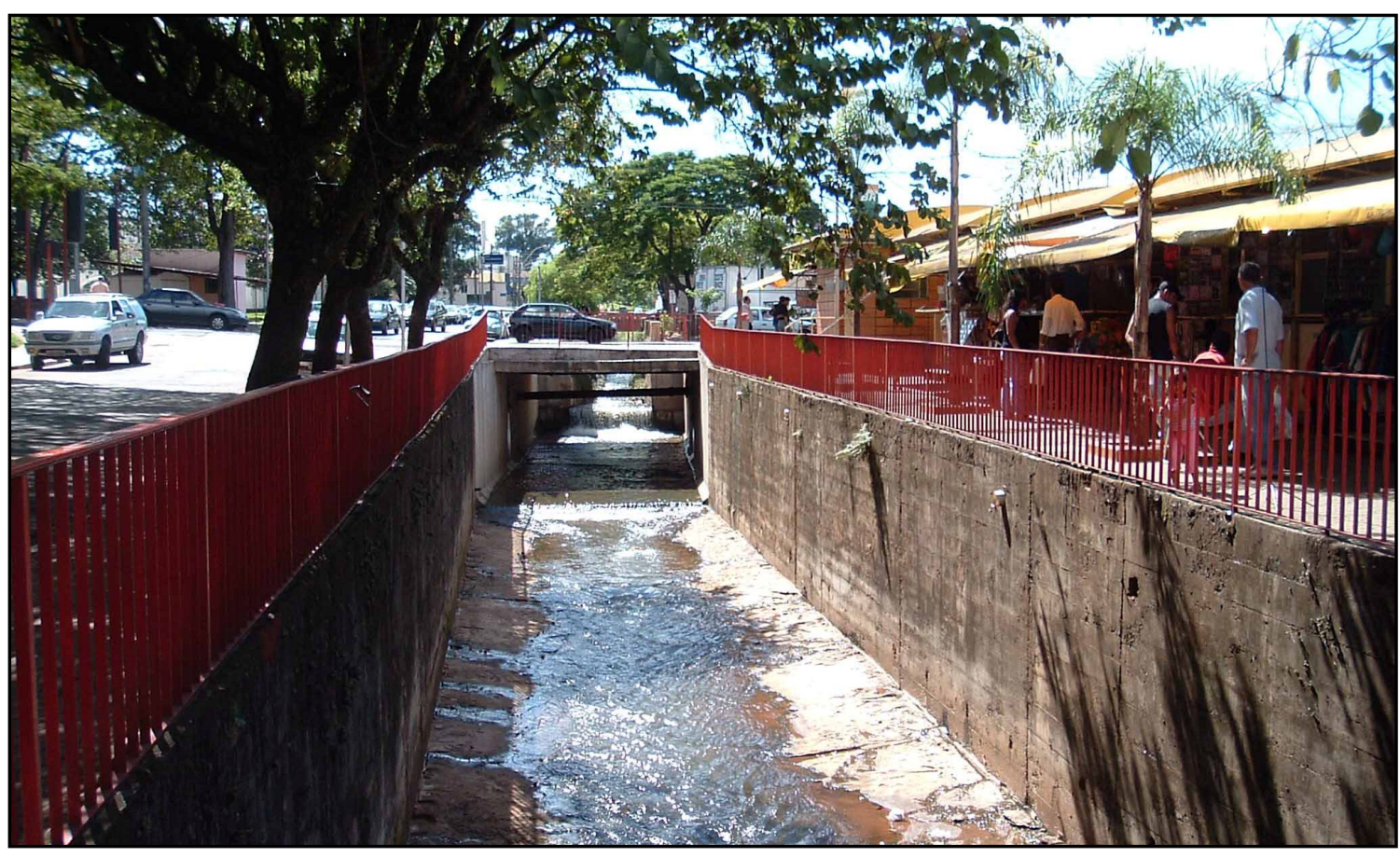

Fonte: Almeida, 2005 Figura 59 - Córrego do Gregório - Região 04 - Região central da área urbana, grande incidência de enchentes. 


\subsubsection{Micro-bacia do Córrego do Tijuco Preto (Figura 53)}

A nascente localiza-se entre as regiões 01 e 05 e percorre parte da região 04 (Figura 60). Desemboca na região 04, no Rio do Monjolinho, na área da marginal (Figura 61).

\subsubsection{Micro-bacia do Córrego do Santa Maria do Leme (Figura 53)}

A nascente localiza-se em área ainda não totalmente urbanizada, entre as regiões 03 e 11, percorrendo a região 11. Desemboca na região 04 no Rio do Monjolinho, na área da marginal (Figuras 62 e 63).

\subsubsection{Micro-bacia do Córrego do Mineirinho (Figura 53)}

A nascente localiza-se na região 03, desemboca no Rio do Monjolinho, na região 08, na área da marginal (Figuras 64 e 65). Essa micro-bacia está inserida em uma área de expansão recente e sofre com os impactos negativos dessa urbanização, assim, o diagnóstico de degradação se repete, como nos anteriores.

Observamos que, como as áreas das micro-bacias anteriores, essas também estão carentes de áreas verdes, altamente impermeabilizadas, muito descaracterizadas e com a ausência de mata ciliar. Como no diagnóstico anterior, parte da região 04 sofre com esse quadro, assim como, parte da região 08. Nesse caso, a enchente acontece em ponto diferente do anterior, mais especificamente na área da marginal, atingindo também os moradores de outras regiões que se utilizam dessa malha viária que liga vários bairros e o centro da cidade. 


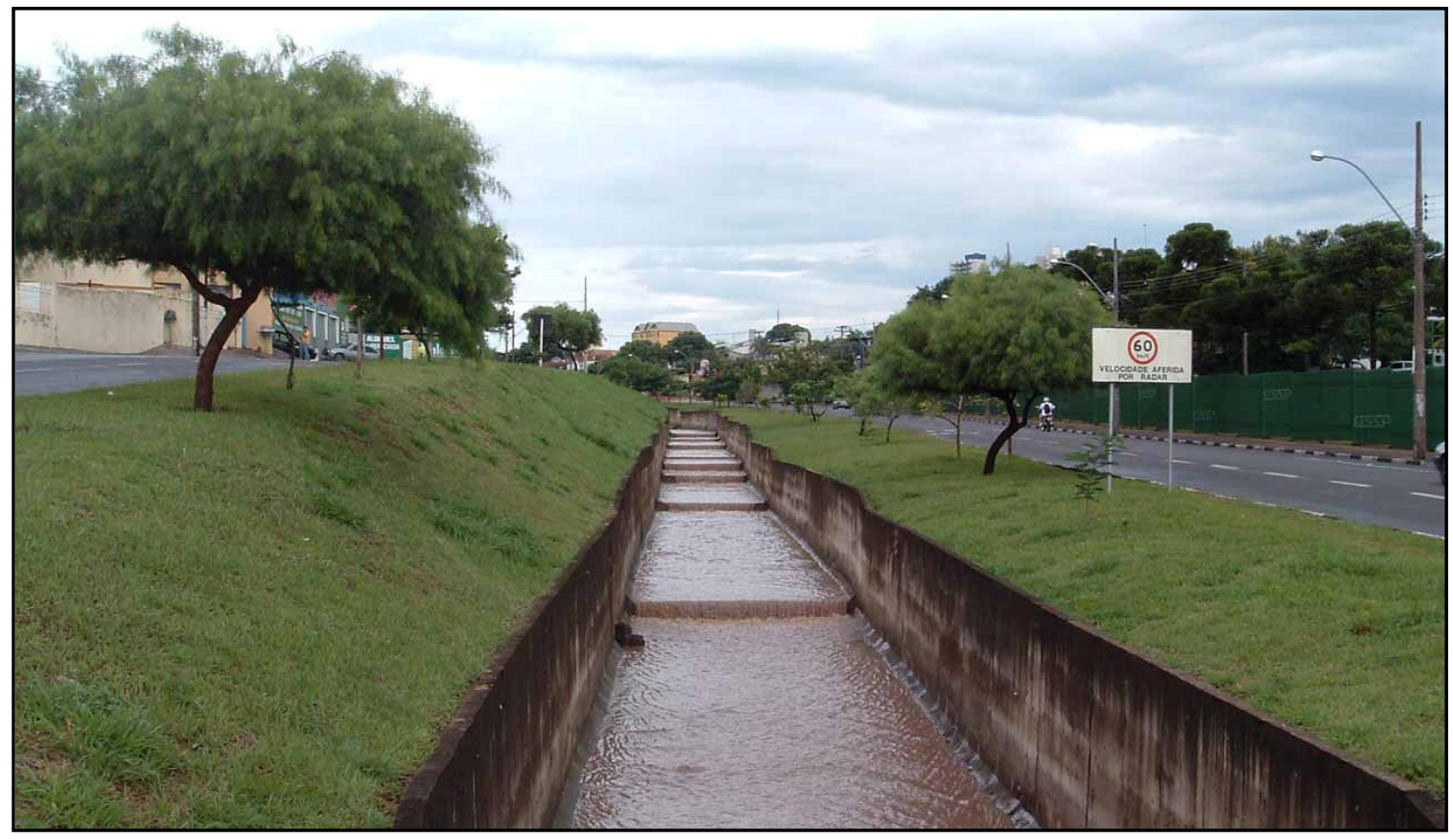

Figura 60 - Córrego do Tijuco Preto - Região 04 - Avenida Marginal

Fonte: Almeida, 2005

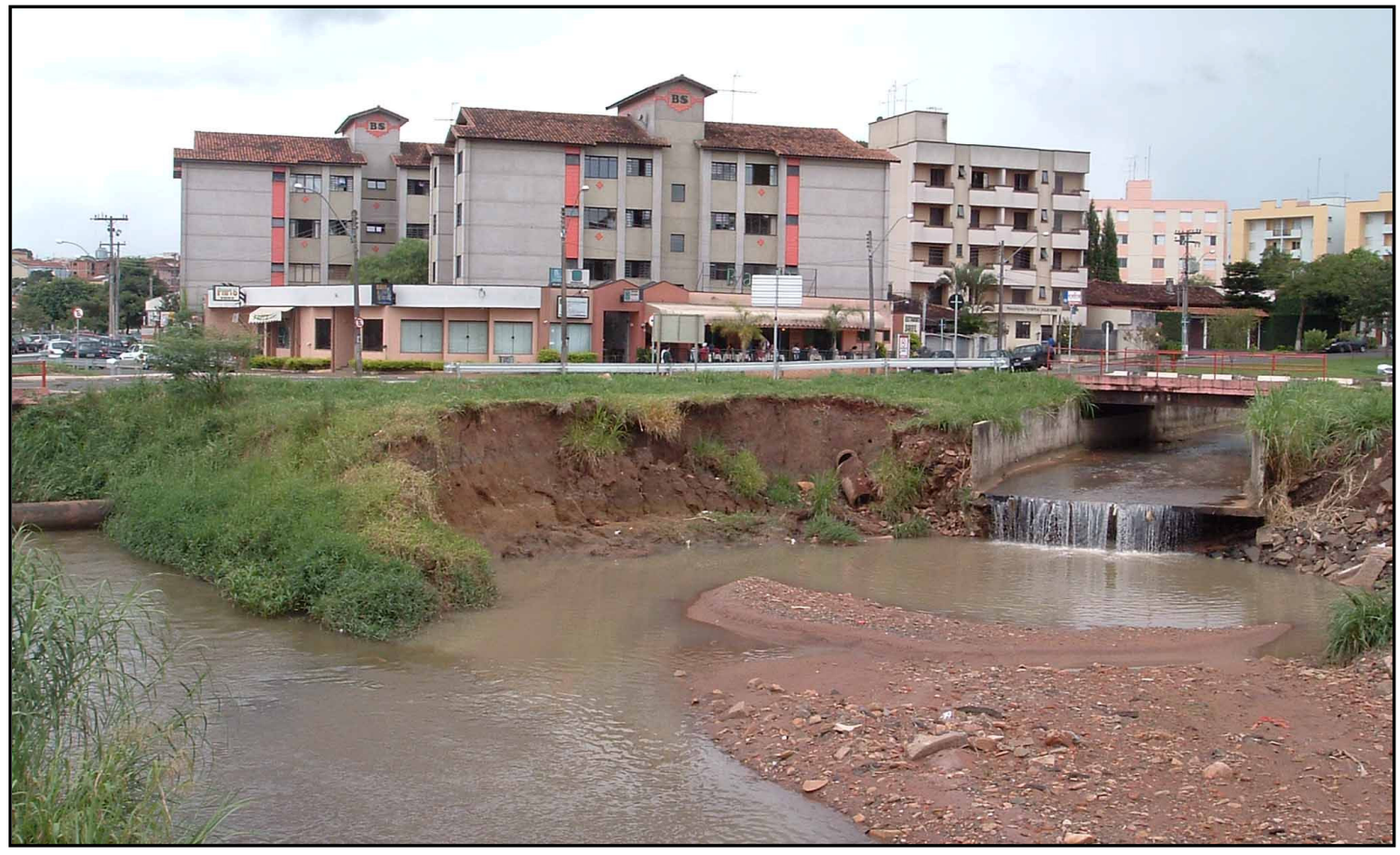

Fonte: Almeida, 2005

Figura 61 - Córrego do Tijuco Preto - Região 11 - Avenida Marginal, próximo à desembocadura no Rio do Monjolinho, região com grande incidência de enchentes. 


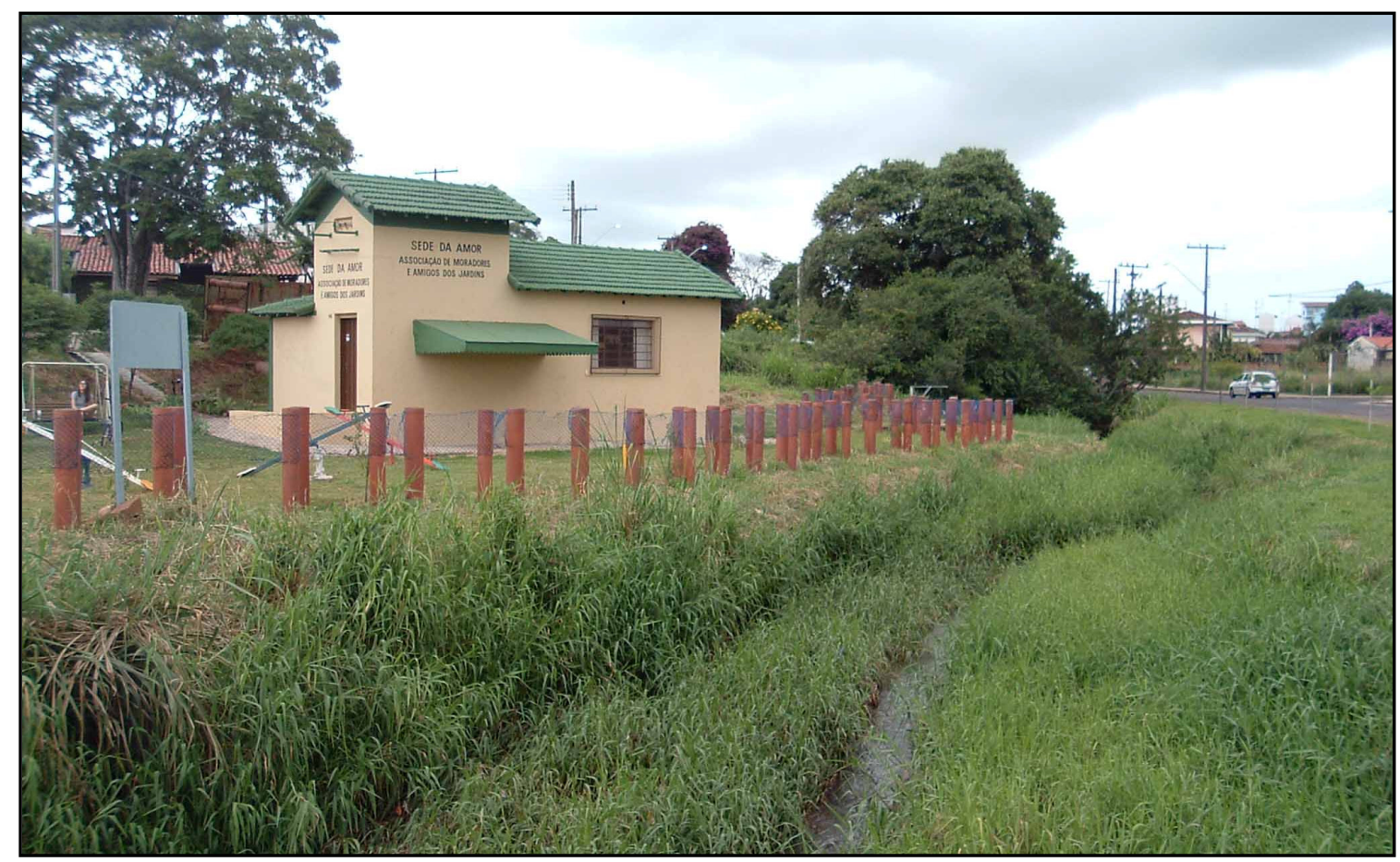

Figura 62 - Córrego Santa Maria do Leme - Região 11 - Avenida Marginal

Fonte: Almeida, 2005

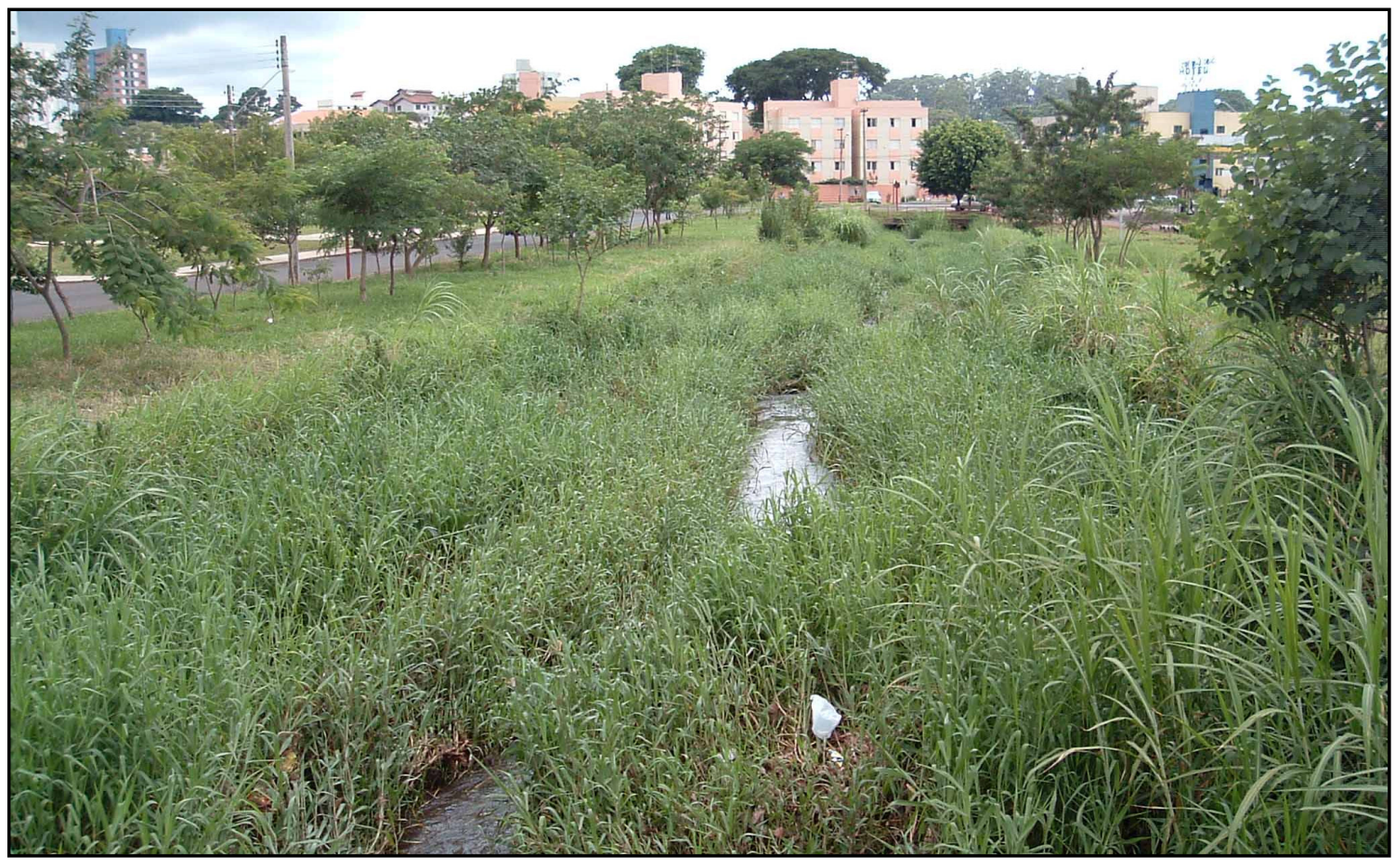

Fonte: Almeida, 2005 Figura 63 - Córrego Santa Maria do Leme - Região 11 - Avenida Marginal, próximo à desembocadura no Rio do Moniolinho. 


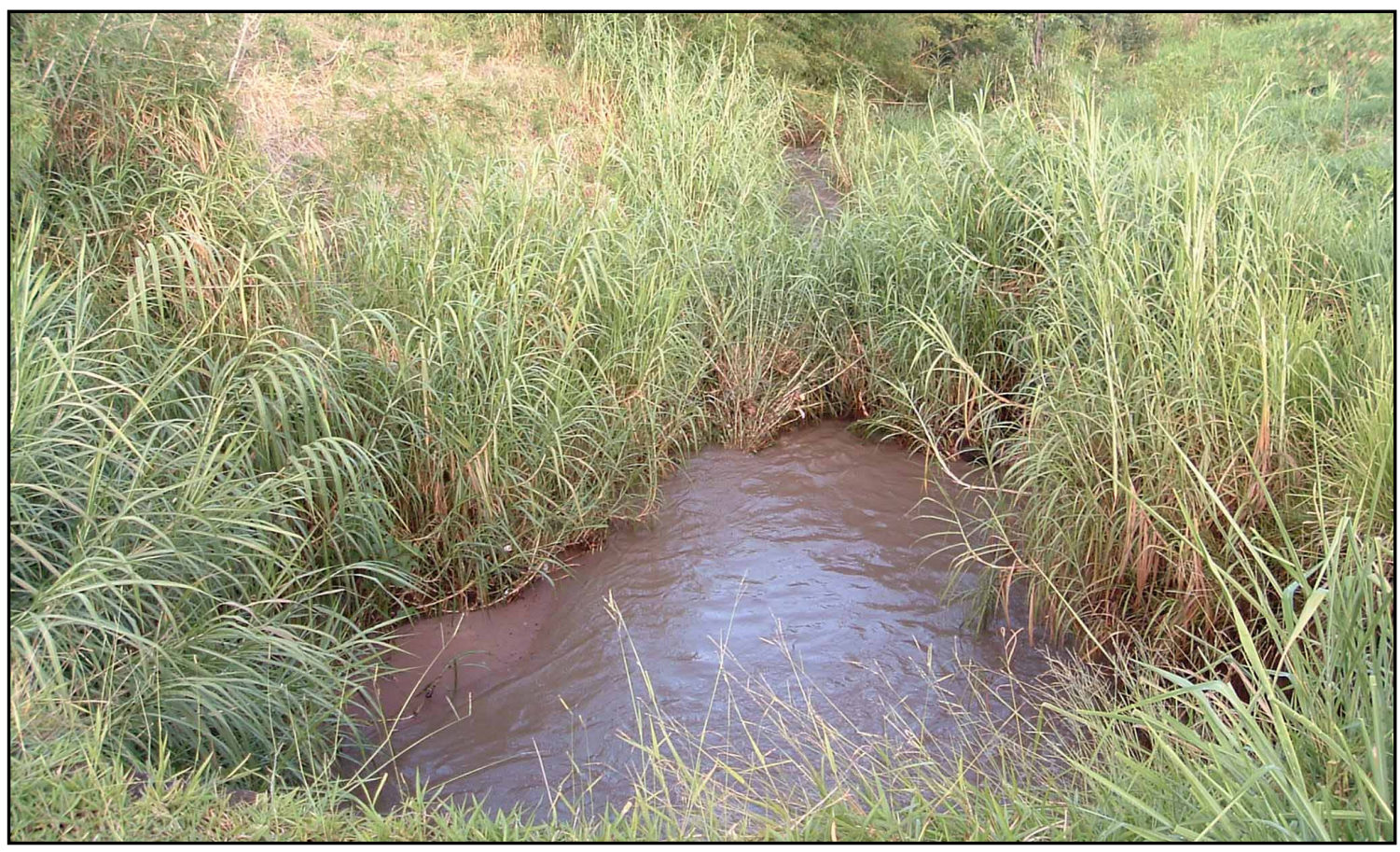

Fonte: Almeida, 2005

Figura 64 - Córrego do Mineirinho - Região 08 - Região próxima à desembocadura do Rio do Moniolinho, urbanização recente.

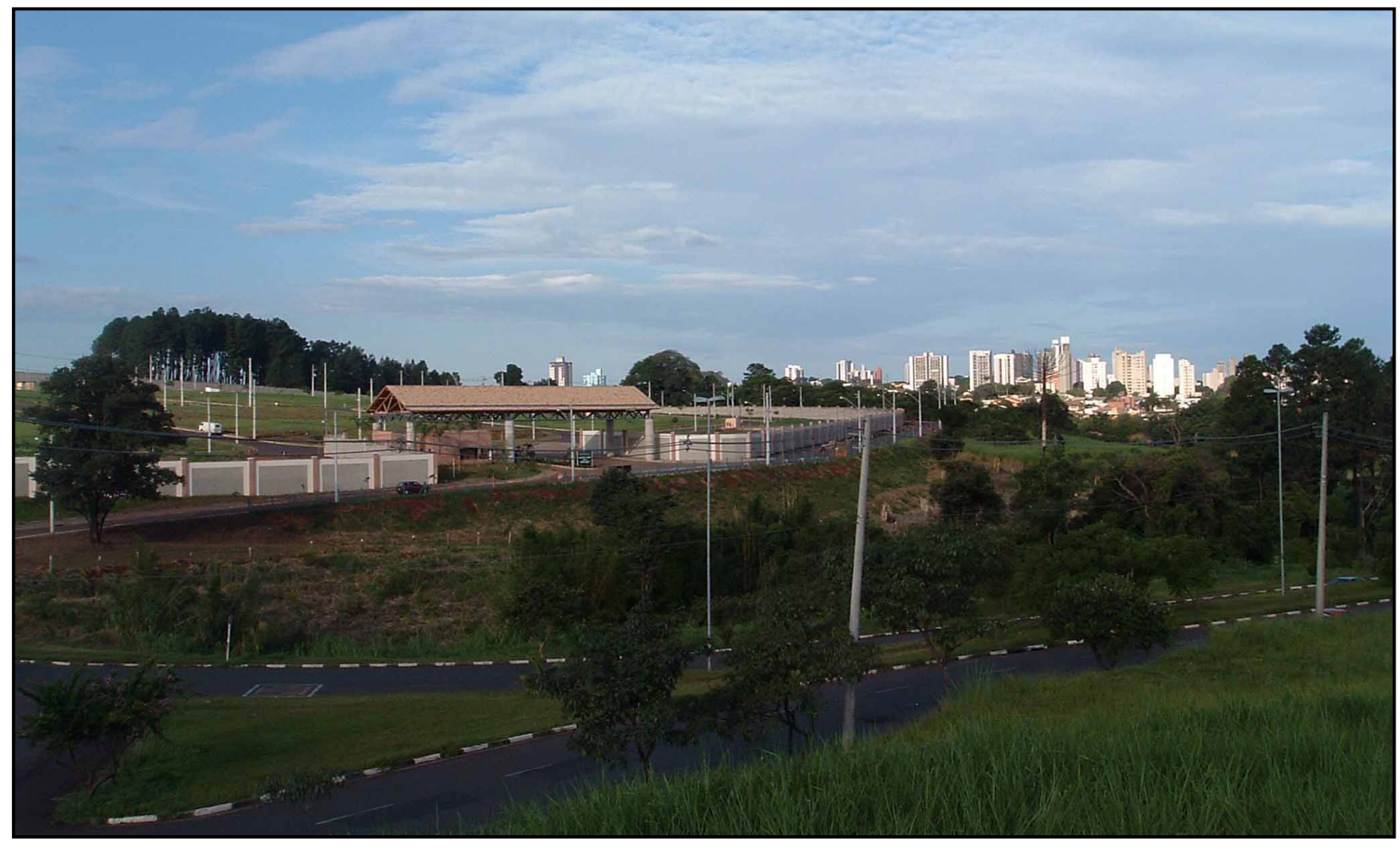

Fonte: Almeida, 2005 Figura 65 - Córrego do Mineirinho - Região 08 - Região próxima à desembocadura do Rio do Monjolinho, panorama da urbanização à margem do Córrego do Mineirinho. 
Pela pequena amostra dessas seis, dentre as 16 micro-bacias urbanas do município de São Carlos, podemos constatar a forma deletéria de urbanização dessas regiões, onde os seus cursos d'águas, sem exceção, estão completamente descaracterizados, isto é, há ausência de matas ciliares, mudanças do curso original, lançamento de esgoto doméstico e industrial etc. Destacamos autores como MACHADO (2003); VALENCIO (et. al., 2003); NEDER (2002) que levantam o debate sobre como o modelo de urbanização brasileiro gera impactos socioambientais negativos, notadamente aos recursos hídricos, exemplificado, nesse estudo de caso, pelas enchentes.

Do ponto de vista de VALENCIO (et. al., 2003), áreas de risco para a ocupação humana não são dadas apenas por circunstâncias naturais como as chuvas. São construídas também pela ação social por meio da impermeabilização do solo; pela decisão econômica, pela via de loteamentos clandestinos ou irregulares e pelo lastro político como a forma de enquadrar as práticas individuais e/ou coletivas, o que ocorre seja através do incentivo, do endosso, ou da omissão. Consideramos que, no município de São Carlos, essas circunstâncias discutidas pelos autores, tanto as naturais quanto às propiciadas pelas ações sociais e políticas são observadas, particularmente, quando nos referimos à degradação dos cursos d'água e das galerias pluviais por meio do descarte do lixo doméstico (garrafas pet, copos plásticos, latas de óleo etc.), da impermeabilização do solo, da supressão de matas ciliares e de áreas irregularmente loteadas e ocupadas que, após a ocupação, acabam por ser regularizadas pelo poder público.

Observamos também que as enchentes sempre ocorrem na mesma época e nas mesmas regiões, gerando os mesmos danos socioeconômicos, abrangendo os mais diversos segmentos sociais, mas, ainda, com respostas ineficazes, tanto do poder público quanto da sociedade civil. Sendo a impermeabilização do solo um dos problemas mais sentidos na área urbana, percebemos, através das demandas solicitadas nas Assembléias Informativas, que a solicitação por áreas verdes (praças, áreas de lazer, arborização urbana etc.) é a que tem o maior número de demandas, mostrando a real carência da área urbana nesse aspecto. Ao mesmo tempo, percebemos que essas demandas são motivadas para a resolução de questões pontuais e são pouquíssimas as solicitações de intervenções para a melhoria da qualidade dos cursos d'água urbanos, apesar de sua visível degradação. 
Por conta desse quadro, destacamos a necessidade de que o desenho institucional do OP/SC permita a troca de informações entre o COP e o movimento ambiental local, representado pelas ONG's atuantes na cidade. Entendemos que citadinos mais bem informados poderiam, nas Assembléias do OP/SC, discutir e promover intervenções, juntamente com o poder público municipal, a fim de buscar uma cidade com mais equidade socioambiental, principalmente no que se refere aos seus recursos hídricos e os impactos negativos advindos desse processo deletério de ocupação do espaço. 


\section{Capítulo 5 - O estudo de caso a luz do arcabouço teórico}

Corroboramos com o arcabouço teórico (NOGUEIRA, 2004; AVRITZER, 2003; NAVARRO, 2003; WAMPLER, 2003; DAGNINO, 2002; SANTOS \& AVRITZER, 2002; FEDOZZI, 2000, dentre outros), de que, teoricamente, o Orçamento Participativo (OP) é um exercício importante de participação política, participação para além da eleitoral, onde os cidadãos deliberam, juntamente com o poder público, sobre questões importantes da gestão municipal, ou seja, o pleno exercício de reivindicação de direitos perdidos.

Entretanto, à luz do estudo de caso, encontramos barreiras e conflitos que podem dificultar o exercício pleno do arcabouço teórico supradito. Conflitos como a convivência em um espaço heterogêneo, característico dos NMS e do OP, espaço onde são necessários o diálogo e a aliança com as diferenças sociais, econômicas, culturais e políticas inerentes ao tecido social são-carlense, diálogo que é imprescindível na busca da melhoria da qualidade de vida dos citadinos pertencentes a todos os segmentos do município.

De acordo com PUTNAM (1996), esse saber conviver com a diferença é próprio do que ele denomina de comunidade cívica. No entanto, nesse estudo de caso encontramos um espaço onde, ao contrário, afloram o individualismo e o bairrismo, que levam a formação de maiorias partidárias e grupos regionais reivindicando para o bem de um único ou de poucos grupos. Observamos também a dificuldade que a sociedade civil local, em todos os seus segmentos, tem em participar da vida pública após anos de domínio político de uma elite que se perpetuou no poder, caracterizando o que ressalta MANZINI-COVRE (1994) de o plano dos sujeitos sujeitados, onde os citadinos sentem-se desmotivados em participar, 
reflexo desse domínio político; ou ainda o que SALES (1994) denomina de cidadania concedida vinculada a não-cidadania, também fruto dessa característica sociopolítica.

Em nossa opinião, respaldada pelos dos dados obtidos na tabulação final dos questionários, dos relatos dos participantes e da observação direta, consideramos que essa característica sociopolítica de sujeitos sujeitados ou de cidadania concedida se evidencia na existência de uma maioria de participantes simpatizantes ou filiados ao Partido dos Trabalhadores, partido do atual governo. Esses simpatizantes estiveram sempre ativos no movimento político local de reivindicação de mudanças e de lideranças de bairros, mas, neste momento específico, essa particularidade do OP/SC pode levar à manipulação ou atuação de maioria partidária, que observamos acontecer em alguns de seus momentos deliberativos, fato sobre o qual NOGUEIRA (2004) alerta quando levanta a discussão sobre a apropriação dos espaços públicos institucionalizados pelo poder público ou pelas maiorias políticas ou partidárias. ARATO (2002), também nos alerta de que não basta a institucionalização de espaços públicos de deliberação, pois não existem garantias de que a sociedade civil efetivamente participe, ou ainda, de que não exista a apropriação desse espaço pelos interesses do poder público e/ou de maiorias. E mesmo que todos os direitos relevantes estejam institucionalizados, não existe a garantia de que a sociedade civil efetivamente se organize, participe da discussão pública e envolva-se com a vida pública do município.

Outra questão particular do OP/SC é sobre o bairrismo, que detectamos ser muito forte na cidade, que leva a dificuldades no momento de serem deliberadas prioridades que não interessam a determinadas regiões, pois, formam-se grupos regionais consolidados, deliberando em favor de sua região ou seu bairro. Um dos pontos mais negativos, que tem reflexo imediato na qualidade socioambiental da cidade, é a dificuldade em deliberar sobre grandes obras como, por exemplo: na recuperação e manutenção de marginais; na conservação e recuperação de matas ciliares; no tratamento de esgoto; na arborização urbana etc.

De nosso ponto de vista, consideramos ser necessária a constante observação dessas duas particularidades do OP/SC, pois corroboramos com o debate levantado por NOGUEIRA (2004) de que, quando não são alcançados os objetivos teóricos propostos por esses espaços públicos institucionalizados, há a possibilidade de seu enfraquecimento ou 
esvaziamento. Ou ainda a possibilidade desse espaço tornar-se mais uma ferramenta de utilização governamental de imposição de certas propostas e projetos de políticas públicas ou em favorecimentos na utilização da política de gastos do orçamento municipal.

Notamos que a possibilidade de enfraquecimento ou esvaziamento pode se configurar no OP/SC, principalmente quando nos deparamos com a queda de participação do ano de 2001 para os demais anos (Quadro 15). No caso da utilização governamental, por ter maioria de participantes simpatizantes do atual partido do governo - o Partido dos Trabalhadores, observamos que, em alguns casos, esse favorecimento pode acontecer na aprovação de propostas ou de políticas públicas especialmente favoráveis ao governo municipal, dito de outra forma, de cunho partidário.

No entanto, como observamos que a configuração de maioria partidária é, em parte, fruto da pouca participação de todos os segmentos da sociedade civil, esta pode ser reversível ou passageira, já que ocorreu uma pequena recuperação no número de participantes no ano de 2004 (Quadro 15). Consideramos a possibilidade dessa reversão a partir da afirmação de DAGNINO (2002) de que o OP é um espaço público caracterizado como um processo mesmo de educação para a participação e, como todo processo educacional, demanda tempo de maturação. A autora destaca também que, sendo um processo, é longo e difícil como o são os processos. Por isso, a análise de experiências recentes, como o OP/SC, pode, aparentemente, considerá-las como um fracasso. Reiteramos então, a necessidade de se considerar esse tempo necessário e/ou propicio para o seu amadurecimento.

\begin{tabular}{|c|c|c|c|}
\hline \multicolumn{4}{|c|}{ Quadro 15 - Evolução do Número de Participantes do OP } \\
\hline $\mathbf{2 0 0 1}$ & $\mathbf{2 0 0 2}$ & $\mathbf{2 0 0 3}$ & $\mathbf{2 0 0 4}$ \\
\hline 4.500 & 2.600 & 1.000 & 1.500 \\
\hline
\end{tabular}

Fonte: Coordenadoria do OP/SC

Quando nos referimos à característica principal dos NMS, que é a questão da heterogeneidade, no OP/SC esta não se restringe apenas a ocasião das Assembléias onde se reúnem todos os segmentos da sociedade civil local. Em muitos casos, as próprias regiões têm composição muito heterogênea, isto é, uma mesma região pode comportar bairros periféricos de baixo, bairros de médio padrão e até condomínios de alto luxo. Essa 
configuração leva a conflitos entre os bairros de uma mesma região, dificultando ainda mais o diálogo com o diferente. Nesse caso, o desenho institucional do OP/SC está dificultando a participação de todos os segmentos da sociedade civil são-carlense, ou seja, coloca para a discussão e deliberação bairros de uma mesma região com demandas muito diferentes e também citadinos com formação socioeconômica e cultural muito distintas, favorecendo, por vezes, àqueles que têm mais condições econômicas de se deslocarem às reuniões, ou aqueles que têm a facilidade de argumentação ou de convencimento frente às questões mais complexas.

Quanto ao objetivo principal desse trabalho, ou seja, se o OP/SC poderá ser uma ferramenta eficaz no planejamento de uma cidade com equidade socioambiental, primeiramente consideramos que: (1) a cidade tem um passivo na implantação e/ou manutenção de equipamentos de infra-estrutura urbana, como asfalto, iluminação pública, postos de saúde, creches; etc.; (2) dentre esses equipamentos, há àqueles cuja carência e/ou falta de manutenção leva a graves problemas ambientais, como galerias pluviais, redes de esgoto, tratamento de esgoto; arborização urbana; (3) além do que questões ambientais outras, que também geram graves problemas, como supressão de matas ciliares e ocupação imprópria de áreas de cerrado e mananciais, que acabam levando a erosões, enchentes, e/ou dificuldade de instalação e manutenção dos equipamentos de infra-estrutura etc. Essas questões acarretam à cidade problemas ambientais importantes, como cursos d'água urbanos sofrendo com a poluição doméstica e industrial, completamente descaracterizados; carência de áreas verdes nos bairros (praças, áreas de lazer, arborização urbana etc.), dentre outros. Essas considerações vêm ao encontro da afirmação de autores como MACHADO (2003); VALENCIO (et. al., 2003); NEDER (2002); ASCERALD (2001); RATTNER (2001); BRAGA (1999); MENEZES (1996) e SILVA (1994) sobre o caráter deletério do modelo de urbanização imposto a maioria dos municípios brasileiros, dentre os quais incluímos o município de São Carlos.

A nosso ver, a ocupação do espaço no município de São Carlos não foge à regra da maioria dos municípios do Brasil. VALENCIO (et. al., 2003) levantam em seu debate a forma inadequada de ocupação e expansão urbana das cidades brasileiras, tanto em áreas de ocupação recente quanto nas antigas. Assentimos com essa afirmação, pois no município de São Carlos, tanto as regiões mais antigas quanto às de expansão mais recente, ou ainda, 
desde os bairros periféricos de baixo até os de alto padrão, sofrem com as conseqüências socioambientais dessa ocupação deletéria, mal planejada e autoritária. Os autores salientam ainda a necessidade de uma responsabilização mútua da sociedade civil e do poder público na identificação das falhas, tanto do poder público no planejamento da cidade quanto das práticas sociais da sociedade civil no espaço urbano e, de nosso ponto de vista, consideramos que essa responsabilização mútua pode encontrar seu lugar nesse espaço institucionalizado que é o OP/SC.

Da perspectiva de RATTNER (2001), a democratização do processo de planejamento urbano é uma necessidade e um desafio ao poder público e à sociedade civil. Em nossa perspectiva, a sociedade civil são-carlense poderia, por ocasião das deliberações do Conselho do Orçamento Participativo (COP), utilizar-se dessa ferramenta para fazer desse planejamento urbano, por vezes autoritário e com intervenções próprias do modelo antiquado de urbanização, um momento de democratização desse processo. Entretanto, observamos que essa possibilidade ainda está muito aquém do possível.

Essa nossa tendência de análise também encontra eco nos debates levantados por KONISKY \& BEIERLE (2001); BRUSENBERG (2000) e MOLL (2000) sobre a importância da participação da sociedade civil nas discussões e deliberações de políticas públicas ambientais. No entanto, a importância e abrangência da questão ambiental ainda não têm a devida atenção e, conseqüentemente, não geram atitudes mais conscientes da sociedade civil local. Esse fato reflete-se nas demandas solicitadas nas Assembléias Gerais Populares Regionais (fase informativa) e nas Assembléias Gerais Populares (fase deliberativa). Se existe esse tipo de solicitação, normalmente ela é de caráter pontual, ou seja, a solicitação da limpeza de um curso d'água do bairro (quando não de canalização), é fruto do incomodo com insetos, mato alto, mau cheiro etc. Como característico desse caráter pontual de demandas, essa mesma população tem intervenções negativas como o descarte de resíduos sólidos nos cursos d'água, residências com nenhuma ou pouca área para infiltração da água das chuvas, consumo excessivo de água etc., intervenções que aceleram ou aumentam o processo de degradação dos córregos e rios, demonstrando que essa demanda não se caracteriza como uma preocupação e/ou conhecimento da abrangência da questão recursos hídricos. Por tudo isso, a possibilidade da sociedade civil local fazer do 
OP/SC um momento para planejar democraticamente a ocupação do espaço urbano, ou planejar intervenções ambientais mais equânimes, ainda não se concretizou.

Assim, assentimos com LEIS (1999) e VIEIRA (1995) quando afirmam que a contenção das causas estruturais das questões ambientais envolve mudanças de mentalidades, valores e comportamentos, além da institucionalização de espaços públicos de discussão e deliberação democráticas de fato. Consideramos que o OP/SC é um espaço possível de deliberação com vistas a uma cidade com equidade socioambiental, ou seja, um espaço onde a população pode decidir sobre as questões urbanas visando à recuperação e/ou conservação ambiental. Todavia, observamos que essa perspectiva ainda não está se firmando em virtude da falta de conhecimento e informações técnicas necessárias aos citadinos acerca das questões ambientais mais urgentes que afetam o município e as possíveis intervenções positivas que o COP pode deliberar nas Assembléias. Em nossa opinião, para que o OP/SC possa cumprir tal papel, ou seja, esse processo de busca a uma cidade mais equânime nos termos socioambientais, necessita de uma atuação mais presente dos movimentos ambientais locais como um momento mesmo de reflexão, discussão e esclarecimento anterior à deliberação daquelas demandas que levem a intervenções ambientais importantes. 


\section{Considerações Finais}

A institucionalização de um espaço democrático de discussão e deliberação dos gastos públicos - como é o Orçamento Participativo, é inédita para a sociedade civil do município de São Carlos, onde os citadinos viram durante muito tempo uma mesma elite se suceder no poder. No entanto, esse espaço ainda não está alcançando os resultados práticos que teoricamente poderia ter, embora tenha obtido até o momento alguns importantes ganhos culturais, políticos, sociais e econômicos. Consideramos que os entraves sociopolíticos e culturais responsáveis por esse contexto podem ser removidos e, assim, todos os segmentos da sociedade civil são-carlense poderão exercer plenamente o seu direito à participação política.

A nosso ver, esse espaço ainda não alcançou o patamar que a teoria nos aponta por não ter a participação efetiva de todos os segmentos da sociedade civil local, consequiência das dificuldades de convivência entre os diferentes perfis socioeconômicos e culturais existentes no interior de muitas regiões, onde estão agrupados bairros de perfis extremamente distintos; da existência de maioria partidária; da existência de um bairrismo acentuado e pela falta de experiência da maioria da sociedade civil local na participação política de fato.

Recomendamos que a questão dos perfis das regiões pode ser resolvida com mudanças importantes no desenho institucional do OP/SC que permitam que bairros com o mesmo perfil socioeconômico e cultural sejam organizados em uma mesma região. 
As ocorrências de maioria partidária e de bairrismo no interior do OP/SC estão sendo acentuadas pela não participação efetiva de todo o tecido social são-carlense. Por ser um espaço público e heterogêneo, o OP/SC permite o acesso, o convívio e o embate entre as diferenças, entretanto, a ausência efetiva de representatividade de todos os segmentos sociais, políticos e culturais também permite o aparecimento de maiorias ou grupos, assim, consideramos que essa configuração tende a se enfraquecer a partir do momento em que a participação de todos se tornar efetiva. Todavia, salientamos ser necessária a constante observação de que realmente essa perspectiva teórica se concretize.

Por termos detectado que um elevado número de participantes não sabe dizer se o OP/SC é eficaz no processo de política local, recomendamos o aumento no número de palestras informativas, além de uma maior atuação dos delegados nas suas regiões, o que propiciaria uma melhor interação da comunidade com o OP.

Com respeito às deliberações sobre as questões ambientais importantes, é preciso ressaltar que o município de São Carlos cresceu rápida e desordenadamente, levando, além de impactos negativos ao meio ambiente, a não extensão de alguns itens de infra-estrutura urbana como asfalto, iluminação pública, creches, postos de saúde etc, a regiões de expansão recente e bairros periféricos. Também o centro histórico da cidade ficou à mercê de uma ocupação sem qualquer preocupação com a preservação e/ou conservação de sua bela e peculiar paisagem arquitetônica urbana, ou seja, os grandes casarões do século XIX, as praças, os cinemas etc. As praças ficaram expostas à ação do tempo; os cinemas deram lugar a bancos e estacionamentos; os casarões, quando não derrubados para dar continuidade à crescente verticalização do centro, foram ocupados, sem qualquer preocupação conservacionista.

Assim, por conta desse quadro urbano, quando nos deparamos com a discussão nas Assembléias para a resolução e/ou encaminhamento de questões relativas aos temas ambientais, observamos que muitos citadinos ainda não se deram conta da importância do tratamento do esgoto, do desperdício no uso indiscriminado de água, da poluiçãa hídrica, da impermeabilização do solo, da conservação das matas ciliares etc., ou seja, ainda não consideram a questão ambiental como mais ampla do que somente a resolução de suas questões pontuais. Essa constatação é essencial para a compreensão do porquê da demanda qualitativamente inferior de obras "verdes", principalmente com relação a grandes obras, 
como tratamento de esgoto, preservação e/ou conservação matas ciliares, resolução da questão das enchentes etc. Essas observações vêm ao encontro da análise dos dados obtidos na tabulação dos questionários, onde se constatou que muitos dos participantes não têm a percepção da questão ambiental inserida em muitos dos problemas de sua região ou de seu bairro.

De nosso ponto de vista, com vistas a uma melhoria e/ou solução dessa questão, recomendamos como imprescindível o papel participativo do movimento ambiental local, aproveitando esse espaço para esclarecer e aprofundar o entendimento que a sociedade civil local tem a respeito das questões ambientais, assim como, encontrar apoio nos citadinos e no poder público as suas sugestões de intervenções positivas. Seria também um momento especial para a população são-carlense deliberar sobre as possíveis intervenções nos impactos negativos causados pela ocupação do espaço urbano e também decidir como continuar seu desenvolvimento de forma a atingir o patamar de uma cidade mais equânime. Para que tal perspectiva se efetive, deixamos como sugestão à Coordenação do OP/SC à abertura de um momento para que esse processo possa ocorrer, assim como, aos movimentos ambientais são-carlenses, representados pelas ONG's locais, a disposição para a formação de parcerias que viabilizem esse processo. 


\section{Referências Bibliográficas}

ACSELRAD, H. (2001). (org.). A duração das cidades: sustentabilidade e risco nas políticas urbanas .Rio de Janeiro. DP\&A

. (2001). Sentidos da sustentabilidade Urbana. In: ACSELRAD, H. (org.). A duração das cidades: sustentabilidade e risco nas políticas urbanas. Rio de Janeiro. DP\&A.

. (2001). Políticas ambientais e construção democrática. In: VIANA, G.;

SILVA, M.; DINIZ, N. (orgs.) (2001). O desafio da sustentabilidade. Um debate socioambiental no Brasil. São Paulo, SP. Ed. Fundação Perseu Abramo.

ALMEIDA, R.C. de \& OLIVEIRA, C. M. de. (2003). Experiência estrangeira na gestão dos recursos hídricos. pp. 31-49. In: SCHALCH, V. \& WENDLAND, E. Pesquisas em meio ambiente. Subsídios para a gestão de políticas publicas. Série Ciências da Engenharia Ambiental. Vol. 2. São Carlos, SP. Ed. Rima.

ALMEIDA, R. C. de. (2001). Memórias do Rio do Monjolinho: o processo de urbanização e os impactos sobre os recursos hídricos. Dissertação (Mestrado). 118p. Escola de Engenharia de São Carlos - Universidade de São Paulo. São Carlos.

ALVAREZ, S. E.; DAGNINO, E.; ESCOBAR, A. (orgs.). (2000). Cultura e política nos movimentos sociais latino-americanos: novas leituras. Belo Horizonte, MG. Ed. UFMG.

ANDRADE, I. A. L. de (1996). Políticas e poder. O discurso da participação. São Paulo, SP. Ed. Ad Hominem.

ANDERSEN, H. T. \& VAN KEMPEN, R. (2003). New trends in urban policies in Europe: evidence from the Netherlands and Denmark. In: Cities, vol. 20, n. ${ }^{\circ}$ 2, p. 77-86. Elsevier Science Ltd. Great Britain.

ARATO, A. (2002). Representação, soberania popular e accountability. In: Revista Lua Nova, n. 55-56, p. 85-103. São Paulo, SP. 
AVRITZER, L. \& NAVARRO, Z. (2003). A inovação democrática no Brasil: o orçamento participativo. São Paulo/SP. Cortez Ed. . (2002). Modelos de deliberação democrática: uma análise do orçamento participativo no Brasil. In: SANTOS, B. da S. (2002). (org.) Democratizar a democracia: os caminhos da democracia participativa. Rio de Janeiro, RJ. Ed. Civilização Brasileira. . (2002). Em busca de um padrão de cidadania mundial. In: Revista Lua Nova, n. 55-56, p. 29-55. São Paulo, SP. . (1994). (org.). Sociedade civil e democratização. Belo Horizonte, MG.

Ed. Del Rey.

BENEVIDES, M. V. VANNUCHI, P. e KERCHE, F. (orgs.). (2003). Reforma política e cidadania. Instituto Cidadania. São Paulo, SP. Ed. Fundação Perseu Abramo.

BENEVIDES, M. V. (2003). Nós, o povo. Reformas políticas para radicalizar a democracia. In: BENEVIDES, M. V. VANNUCHI, P. e KERCHE, F. (orgs.). Reforma política e cidadania. Instituto Cidadania. São Paulo, SP. Ed. Fundação Perseu Abramo. (1996). A cidadania ativa, referendo, plebiscito e iniciativa popular.

São Paulo, SP. Ática.

BOBBIO, N. (2000). O futuro da democracia. São Paulo, SP. Paz e Terra.

BODSTEIN, R. C. DE A. (1997). Cidadania e modernidade: emergência da questão social na agenda pública. In: Cadernos de Saúde Pública, v. 13, n. ${ }^{\circ}$. Rio de Janeiro.

BORN, R. H. (1999). Caminhos, descaminhos e desafios da Agenda 21 brasileira. In: Revista Debates Sócio-Ambientais, ano IV, n. ${ }^{\circ}$ 11, pp. 09-11.

BRAGA, B.; REBOUÇAS, A. da C.; TUNDISI, J. G. (1999). Águas doces no Brasil: capital ecológico, uso e conservação. São Paulo, SP. Escrituras Editora. 
BRAGA, T. (1997). Conflito socioambiental e constituição de atores ambientalistas: um estudo sobre as cidades industriais da Bacia do Rio Piracicaba/MG. In: Anais do 7. ${ }^{o}$ Encontro Nacional da ANPUR.

BUSENBERG, G. J. (2000). Resources, Political Support, and Citizen Participation in Environmental Policy: a reexaminationm of conventional wisdom. In: Society \& Natural Resources, 13: 579-587. EUA. Copyright Taylor \& Francis.

CALDERÓN, A. I. (1997). Meio ambiente: democracia e participação popular. In: Revista Debates Sócio-Ambientais, ano II, n. ${ }^{\circ}$ 06, pp. 02-05.

CARVAlHO, M. do C. A. A.; TEIXEIRA, A. C. C. (Orgs.) (2000). Conselhos gestores de políticas públicas. São Paulo, SP. Polis.

CASSIA-BAVA, S. (2001). Participação, representação e novas formas de diálogo. Cadernos Polis. Programa de Gestão Pública e Cidadania/EAESP/FGV. São Paulo, SP.

CASTELlS. M. (1999). A era da informação: economia, sociedade e cultura. Vol. 2. O poder da identidade. São Paulo, SP. Paz e Terra. (1980). Cidade, democracia e socialismo. São Paulo, SP. Paz e Terra.

CHRISTOFOlETTI, A. (1993). Meio Ambiente e Urbanização no Mundo Tropical. In: SANTOS, M., et. al. Natureza e Sociedade de Hoje: uma leitura geográfica. São Paulo, SP. Ed. Hucitec.

COHEN, J. (2000). Igualitarismo, internacionalização e cidadania. In: Revista Brasileira de Ciências Sociais. Vol. 15, no 44.

COSTA, S. (1997). Movimentos sociais, democratização e a construção de esferas públicas locais. In: Revista Brasileira de Ciências Sociais. V. 12, n. ${ }^{\circ} 35$, fevereiro de 1997. São Paulo, SP. 
CRUZ, R. de la. (1997). Os novos movimentos sociais. In: SCHERER-WARREN, I. \& KRISCHKE, P. J. (orgs.). Uma revolução no cotidiano? Os novos movimentos sociais na América do Sul. 2. a edição. São Paulo, SP. Editora Brasiliense.

DAGNINO, E. (org.). (2002). Sociedade civil e espaços públicos no Brasil. São Paulo, SP. Ed. Paz e Terra.

. (2000). Cultura, cidadania e democracia. A transformação dos discursos e práticas na esquerda latino-americana. In: ALVAREZ, S. E.; DAGNINO, E.; ESCOBAR, A. (orgs.). Cultura e política nos movimentos sociais latino-americanos: novas leituras. Belo Horizonte, MG. Ed. UFMG. . (org.). (1994). Os anos 90: política e sociedade no Brasil. São Paulo, SP. Brasiliense.

DAHRENDORF, R. (1992). O conflito social moderno. Um ensaio sobre a política da liberdade. 4. ${ }^{\text {a }}$ edição. São Paulo, SP. Edusp.

DALTON, R.; KUECHLER, M. (orgs. (1990). Challenging the political order: new social and political movements in western democracies. Oxford. Polity Press.

DI CIOMMO, R. C. (1999). A ação coletiva e a organização dos cidadãos. In: Revista Jurídica. UNIJUS. Ano II, n. 1 (out, 1999), pp. 165/75. Uberaba, MG.

DOWBOR, L. (2001). A comunidade inteligente: visitando as experiências de gestão local. Cadernos Polis. Programa de Gestão Pública e Cidadania/EAESP/FGV. São Paulo, SP.

DOWBOR, L. (2000). Prefácio. In: FISCHER, N. B. \& MOLL, J. (orgs.). Por uma Nova Esfera Pública: a experiência do orçamento participativo. Petrópolis, RJ. Ed. Vozes.

DRAIBE, S. (1985). Rumos e metamorfoses. Estado e industrialização no Brasil. Rio de Janeiro, RJ. Paz e Terra.

DURING, A. B. (1989). Action at the grassroots: Fighting poverty and environmental decline. Washigton, D.C.: Worldwatch Paper. 69 p. 
ESPÍNDOLA, E. L. G. (et. al.) (2000). A bacia hidrográfica do Rio do Monjolinho: uma abordagem ecossistêmica e a visão interdisciplinar. São Carlos, SP. Ed. Rima.

FAORO, R. (1958). Os donos do poder. Porto Alegre, RS. Ed. Globo.

FARIA, J. E. (org.). (2002). Regulação, direito e democracia. São Paulo, SP. Ed. Fundação Perseu Abramo.

FEDOZZI, L. (2000). Orçamento Participativo e Esfera Pública. In: FISCHER, N. B. \& MOLL, J. (orgs.). Por uma Nova Esfera Pública: a experiência do orçamento participativo. Petrópolis, RJ. Ed. Vozes.

FELICIDADE, N.; MARTINS, R. C.; LEME, A. A. (2001). Uso e Gestão dos Recursos Hídricos no Brasil. São Carlos, SP. Ed. Rima.

FELICIDADE, N.; VARGAS, M. C.; MIRANDA, C. O. (2001). O Processo de Interiorização do Desenvolvimento e suas Implicações ao Acesso e Uso da Água pelo Cidadão: desafios econômicos, sociais e político-institucionais do caso paulista. In: FELICIDADE, N.; MARTINS, R. C.; LEME, A. A. Uso e Gestão dos Recursos Hídricos no Brasil. São Carlos, SP. Ed. Rima.

FERREIRA, L. da C. \& JACOBI, P. (1999). As cidades e a sustentabilidade. In: Revista Debates Sócio-Ambientais, ano IV, n. ${ }^{\circ}$ 11, p. 06-07.

FISCHER, N. B. \& MOLL, J. (orgs.). 2000. Por uma Nova Esfera Pública: a experiência do orçamento participativo. Petrópolis, RJ. Ed. Vozes.

FORESTER, J. (1993). Critical theory, public policy, and planning practice. New York, UN. State University of NY Press.

FOUCAULT, M. (1979). Microfísica do poder. 19 ${ }^{\mathrm{a}}$. ed. São Paulo, SP. Ed. Graal.

FURRIELA, R. B. (2002). Democracia, cidadania e proteção do meio ambiente. São Paulo, SP. Annablume Ed. 
FRANK, A. G. \& FUENTES, M. (1989). Dez teses acerca dos movimentos sociais. In: Revista Lua Nova. pp 17:19.

FREY, K. (2000). Políticas públicas: um debate conceitual e reflexões referentes à prática da análise de políticas públicas no Brasil. In: Revista Planejamento e Políticas Públicas, $n$. 21. São Paulo, SP.

GENRO, T. (2000). Co-gestão: reforma democrática do estado. In: FISCHER, N. B. \& MOLL, J. (orgs.). Por uma Nova Esfera Pública: a experiência do orçamento participativo. Petrópolis, RJ. Ed. Vozes.

HOLANDA, S. B. (1993). Raízes do Brasil. Rio de Janeiro, RJ. Ed. José Olympio.

LE GOFF, J. (1998). Por amor às cidades. São Paulo, SP. Ed. UNESP.

GIDDENS, A. (1991). As conseqüências da modernidade. São Paulo, SP. Ed. UNESP.

GOLDENBERG, M. (1997). A arte de pesquisar: como fazer pesquisa qualitativa em Ciências Sociais. Rio de Janeiro/RJ. Ed. Record.

GRÜN, M. (1996) Ética e Educação Ambiental - A Conexão Necessária. São Paulo. Papirus.

GUIMARÃES, R. P. (1999). Agenda 21 e desenvolvimento sustentável. In: Revista Debates Sócio-Ambientais, ano IV, n. ${ }^{\circ}$ 11, pp. 01-03.

HOGAN, Daniel Joseph \& VIEIRA, Paulo Freire (orgs.) (1995). Dilemas Socioambientais e Desenvolvimento Sustentável. Campinas, SP. Ed. Unicamp.

HONNETH, A. (2001). Democracia como cooperação reflexiva. John Dewey e a teoria democrática hoje. In: SOUZA, J. (2001). (org). Democracia hoje. Novos desafios para a teoria democrática contemporânea. Brasília, DF. Ed. UnB.

JACOBI, P. (2002). Políticas sociais locais e os desafios da participação citadina. In: Revista Ciência e Saúde Coletiva, 7(3), p443-454. São Paulo, SP 
(2000). Educação, ampliação da cidadania e participação. In: Revista Educação e Pesquisa, v. 26. n. 2, p.11-29. São Paulo, SP.

. (1999). Cidade de meio ambiente: percepções e práticas em São Paulo. São Paulo, SP. Ed. Annablume.

(1997). Participação popular e a construção de uma nova institucionalidade. In: Revista Debates Sócio-Ambientais, ano II, n. ${ }^{\circ}$ 06, pp.01-02. . (1989). Movimentos sociais e políticas públicas. São Paulo, SP. Cortez Ed.

JELIN, E. (1994). Construir a cidadania: uma visão desde baixo. In: Lua Nova. Revista de Cultura e Política. N. ${ }^{\circ}$ 33. CEDEC. São Paulo, SP.

JOVCHELOVITCH, S. (2000). Representações sociais e esfera pública. A construção simbólica dos espaços públicos no Brasil. Petrópolis, RJ. Editora Vozes.

KÄRNER, H. (1997). Movimentos sociais: revolução no cotidiano. In: SCHERERWARREN, I. \& KRISCHKE, P. J. (orgs.). Uma revolução no cotidiano? Os novos movimentos sociais na América do Sul. 2. edição. São Paulo. Editora Brasiliense.

KONISKY, D. M. \& BEIERLE, T. C. (2001). Innovations in public participation and environmental decision making: examples from the Great Lakes region. In: Society and Natural Resources, 14:815-826. EUA. Taylor \& Francis.

KOWARICK, L. (org.) (1994). As lutas sociais e a cidade. São Paulo: passado e presente.

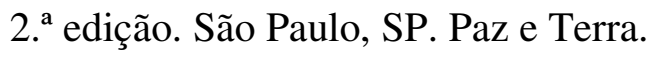

LARANJEIRA, S. (1990). (org.) Classes e movimentos sociais na América Latina. São Paulo, SP. Ed. Hucitec.

LAVALlE, A. G. (2003). Cidadania, igualdade e diferença. In: Revista Lua Nova, $n^{o} 59$. São Paulo, SP.

LEIS, H. R. (1999). A Modernidade Insustentável: as críticas do ambientalismo à sociedade contemporânea. Petrópolis, RJ. Vozes. 
LEIS, H. R. \& VIOLA, E. J. (1996). A emergência e evolução do ambientalismo no Brasil. In: LEIS, H. R. O Labirinto: ensaios sobre ambientalismo e globalização. São Paulo, SP. Ed. Gaia.

LISZT, V. (2004). Cidadania e Globalização. Rio de Janeiro, RJ. Ed. Record.

LOMBARDO, M. A. (1995). Área de Proteção Ambiental. In: TAUK-TORNISIELO, S. M. et al. (Org.). Análise ambiental: estratégias e ações. 1. ed. Rio Claro: T. A. Queiroz Editor. p. 166-168.

MACEDO, R. K. (1995). Metodologias para a sustentabilidade ambiental: capacidade suporte de ecossistemas. In: TAUK-TORNISIELO, S. M. et al. (Org.). Análise ambiental: estratégias e ações. 1. ed. Rio Claro, SP. T. A. Queiroz Editor.

MAGLIO, I. C. (1995). Gestão urbana e qualidade de vida: um estudo de caso. In: TAUKTORNISIELO, S. M. et al. (Org.). Análise Ambiental: estratégias e ações. 1. ed. Rio Claro, SP. T. A. Queiroz Editor.

MACHADO, C. J. S. (2003). Recursos Hídricos e Cidadania no Brasil: limites, alternativas e desafios. In: Revista Ambiente \& Sociedade. Vol. 6. Campinas, jul/dez/. 2003.

MAGNOLI, M. M.(1994). Recursos humanos e meio ambiente. In: Paisagem e Ambiente: ensaios (FAU-USP), São Paulo, n. 1 e 2, p.65-76. Edição Especial

MALAGODI, M. A. S. (1999). Estudo sobre o programa de reflorestamento ciliar: subsídios para compreensão das relações entre extensão rural e educação ambiental. Dissertação (Mestrado em Ciências Florestais) 309 p.- Escola Superior de Agricultura "Luiz de Queiroz", Universidade de São Paulo, Piracicaba.

MANTOVANELI JR., O. (2001). Gestão estratégica, políticas públicas e sustentabilidade: um outro olhar sobre o orçamento participativo. Tese (Doutorado). 303p. Universidade Estadual Paulista. Araraquara.

MANZINI COVRE, M. L. (1994). Cidadania, cultura e sujeitos. In: SPINK, M.J. A cidadania em construção. Uma reflexão transdisciplinar. São Paulo, SP. Cortez Ed. 
MARICATO, E. (2001). Metrópole periférica, desigualdade social e meio ambiente. In: VIANA, G.; SILVA, M.; DINIZ, N. (orgs.). O desafio da sustentabilidade. Um debate socioambiental no Brasil. São Paulo, SP. Ed. Fundação Perseu Abramo.

MARINELLI, C. E. (et. al.). (2000). Limnologia. In: ESPÍNDOLA, E. L. G. (et. al.). A bacia hidrográfica do Rio do Monjolinho: uma abordagem ecossistêmica e a visão interdisciplinar. São Carlos, SP. Ed. Rima.

MARSHALL, T. H. (1967). Cidadania, classe social e status. Rio de Janeiro, RJ. Zahar.

MARTINS, R. \& VALENCIO , N. F. L. S. (orgs). Uso e Gestão dos Recursos Hídricos no Brasil. Desafios teóricos e político-institucionais. Vol. II. São Carlos, SP. Ed. Rima.

MCCORMICK, J. (1992). Rumo ao paraíso. História do movimento ambientalista. Rio de Janeiro, RJ. Relume Damará.

MELLO, N. A. (1995). Gestão urbana e qualidade de vida. In: TAUK-TORNISIELO, S. M. et al. (org.). Análise ambiental: estratégias e ações. 1. ed. Rio Claro, SP. T. A. Queiroz Editor.

MENEZES, C. L. (1996). Desenvolvimento Urbano e Meio Ambiente. A experiência de Curitiba. Campinas,SP. Papirus.

MERICO, L. F. K. (2001). Políticas públicas para a sustentabilidade. In: VIANA, G.; SILVA, M.; DINIZ, N. (orgs.). O desafio da sustentabilidade. Um debate socioambiental no Brasil. São Paulo, SP. Ed. Fundação Perseu Abramo.

MIRANDA, C. O. (2001). O Papel Político-Institucional dos Comitês de Bacia Hidrográfica no estado de São Paulo: um estudo de caso. In: FELICIDADE, N.; MARTINS, R. C.; LEME, A. A. Uso e Gestão dos Recursos Hídricos no Brasil. Vol. I. São Carlos, SP. Ed. Rima.

MOLL, L. H. (2000). Uma ferramenta para executar políticas públicas ecológicas. Orçamento Participativo. In: FISCHER N. B. \& MOLL, J. (orgs.). Por uma Nova Esfera Pública: a experiência do orçamento participativo. Petrópolis, RJ. Ed. Vozes. 
MOLL, J. \& FISCHER, N. B. (2000). Pedagogias nos tempos do OP em Porto Alegrepossiveis implicações educativas na ampliação da esfera pública. In: FISCHER, N. B. \& MOLL, J. (orgs.). Por uma Nova Esfera Pública: a experiência do orçamento participativo. Petrópolis, RJ. Ed. Vozes.

MUNCK. G. L. (1997). Formação de atores, coordenação social e estratégia política: problemas conceituais do estudo dos movimentos sociais. In: Revista Dados. V. 40, n. ${ }^{\circ} 1$. Rio de Janeiro.

NAVARRO, Z. (2003). O orçamento participativo de Porto Alegre (1989-2002): um conciso comentário crítico. In: AVRITZER, L. NAVARRO, Z. (2003). A inovação democrática no Brasil: o orçamento participativo. São Paulo,SP. Cortez Ed.

NEDER, R. T. (2002). Crise socioambiental - Estado \& Sociedade no Brasil (1982 1998). São Paulo, SP. Annablume: Fapesp.

NOGUEIRA, M. A. (2004). Um estado para a sociedade civil. Temas éticos e políticos da gestão democrática. São Paulo, SP. Cortez Ed.

OLIVEIRA, F. de; PAOLI, M. C.; REZEK, C.S. (2003). Orçamento Participativo. Uma invenção da política. In: BENEVIDES, M. V. VANNUCHI, P. e KERCHE, F. (orgs.). Reforma política e cidadania. Instituto Cidadania. São Paulo, SP. Ed. Fundação Perseu Abramo.

PÁDUA, E. M. M. de. (2000). Metodologia da pesquisa: abordagem teórico-prática. $6^{\mathrm{a}}$ edição. Campinas,SP. Ed. Papirus.

PAOLI, M. C. (2002). Empresas e responsabilidade social: os enredamentos da cidadania no Brasil. In: SANTOS, B. da S. (2002). (org.) Democratizar a democracia: os caminhos da democracia participativa. Rio de Janeiro, RJ. Ed. Civilização Brasileira.

. (2000). Direitos sociais. Conflitos e negociações no Brasil contemporâneo. In: ALVAREZ, S. E.; DAGNINO, E.; ESCOBAR, A. (orgs.). Cultura e política nos movimentos sociais latino-americanos: novas leituras. Belo Horizonte, MG. Ed. UFMG. 
PATERMAN, C. (1992). Participação e teoria democrática. Rio de Janeiro, RJ. Paz e Terra.

PACHECO, R.S. (1991). (et. al.) Meio ambiente urbano: velhas dicotomias e novas perspectivas de análise. In: Anais do IV Encontro Nacional da ANPUR.

PONTE, V. M. D. (1990). Estruturas e sujeitos na análise da América Latina. In: LARANJEIRA, S. (1990). (org.) Classes e movimentos sociais na América Latina. São Paulo, SP. Ed. Hucitec.

POULANTZAS, N. (2000). O estado, o poder, o socialismo. 4. ${ }^{\text {a }}$ ed. São Paulo, SP. Ed. Graal.

PUTNAM, R. (1996). Comunidade e democracia. A experiência da Itália moderna. Rio de Janeiro, RJ. Fundação Getulio Vargas Ed.

RATTNER, H. (2001). Prefácio. In: ACSELRAD, H. (2001). (org.). A duração das cidades: sustentabilidade e risco nas políticas urbanas. Rio de Janeiro, RJ. DP\&A.

REIGOTA, Marcos. (1995). Meio Ambiente e Representação Social. Coleção Questões da Nossa Época. São Paulo, SP. Cortez.

REIS, E.; ALMEIDA, M. H. T. de; FRY, P. (1995). Pluralismo, espaço social e pesquisa. São Paulo, SP. ANPOCS. Ed. Hucitec.

RENN, O.; WEBLER, T.; WIEDERMANN, P. (1995). Fairness and competence in citizen participation. London. Kluwer Academic Publishers.

RIBEIRO, A. C. T. (2003). Experiências de orçamento participativo no Brasil. São Paulo, SP. Fórum Nacional de Participação Popular. Ed. Vozes.

RICHARDSON, R. J. (1999). Pesquisa Social. Métodos e técnicas. $3^{\mathrm{a}}$. Edição. São Paulo, SP. Ed. Atlas. 
RODRIGUES, I. A. (1998). A Dimensão sócio-ambiental e o manejo de áreas naturais sob proteção. In: BARBOSA, S. R. C. S. (Org.). A temática ambiental e a pluralidade do ciclo de seminários do NEPAM. Campinas: NEPAM/UNICAMP. p. 153-178 (Série Divulgação Acadêmica, 4).

RODRIGUES, R. R. (1989). Análise estrutural das formações florestais ripárias. In: Simpósio sobre Mata Ciliar, 1989, Campinas. Anais do Simpósio sobre Mata Ciliar. Campinas:Fundação Cargill. 335 p. p.99-119.

RODRIGUES, R. R. \& GANDOLFI, S. (2000). Conceitos, tendências e ações para a recuperação de florestas ciliares. In: RODRIGUES, R. R.; LEITÃO FILHO, H. F. (ed.). Matas ciliares: conservação e recuperação. 1. ed. São Paulo, SP. EDUSP.

RUSCHEINSKY, A. (1999). Metamorfoses da cidadania. Sujeitos sociais, cultura política e institucionalidade. São Leopoldo, RS. Ed. da Unisinos.

SACHS, I. (1994). Estratégias de transição para o século XXI. In: BURSZTYN, M. (org.) Para pensar o desenvolvimento sustentável. São Paulo, SP. Brasiliense. (1993). Estratégias: desenvolvimento e meio ambiente. São Paulo, SP. Estúdio Nobel.

SADER, E. (2002). Para outras democracias. In: SANTOS, B. da S. (2002). (org.) Democratizar a democracia: os caminhos da democracia participativa. Rio de Janeiro, RJ. Ed. Civilização Brasileira.

SANTOS, B. da S. (2002). (org.) Democratizar a democracia: os caminhos da democracia participativa. Rio de Janeiro, RJ. Ed. Civilização Brasileira.

(2002). Orçamento Participativo em Porto Alegre: para uma democracia redistributiva. In: SANTOS, B. da S. (2002). (org.) Democratizar a democracia: os caminhos da democracia participativa. Rio de Janeiro, RJ. Ed. Civilização Brasileira. 
\& AVRITZER, L. (2002). Para ampliar o cânone democrático. In: SANTOS, B. da S. (2002). (org.) Democratizar a democracia: os caminhos da democracia participativa. Rio de Janeiro, RJ. Ed. Civilização Brasileira.

- (2002). A crítica da razão indolente: contra o desperdício da experiência. Vol. 1. Para um novo senso comum. A ciência, o direito e a política na

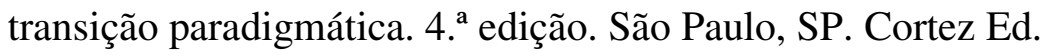

. (2001). Pela mão de Alice: o social e o político na pós-modernidade.

8. ${ }^{\text {a }}$ edição. São Paulo, SP. Ed. Cortez.

SANTOS, J. E. \& CAVALHEIRO, F. (1988). Procedimentos básicos para o manejo dos ecossistemas: ecologia de ecossistemas. In Anais do IV Seminário Regional de Ecologia. São Carlos, PPG-ERN, UFSCar, p 73-109.

SANTOS, M. (1993). A urbanização brasileira. São Paulo, SP. Ed. HUCITEC.

(1991). Metamorfoses do espaço habitado: fundamentos teóricos e metodológicos da geografia. São Paulo, SP. Ed. HICITEC.

SANTOS, W. G. (1994). Razões da desordem. Rio de Janeiro, RJ. Ed. Rocco. . (1979). Cidadania e justiça. Rio de Janeiro, RJ. Campus.

SCOTT, A. (1990). Ideology and the new social movements. Londres. Unwin Hyman.

SATO, M. (1997). Educação para o Ambiente Amazônico. Tese (Doutorado). São Carlos, SP. Centro de Ciências Biológicas e da Saúde da Universidade Federal de São Carlos.

SCHERER-WARREN, I. \& KRISCHKE, P. J. (orgs.). (1987). Uma revolução no cotidiano? Os novos movimentos sociais na América do Sul. 2. ${ }^{a}$ edição. São Paulo, SP. Editora Brasiliense.

SCHERER-WARREN, I. (1987). O caráter dos novos movimentos sociais. In: SCHERERWARREN, I. \& KRISCHKE, P. J. (orgs.). Uma revolução no cotidiano? Os novos movimentos sociais na América do Sul. 2. ${ }^{\text {a }}$ edição. São Paulo, SP. Editora Brasiliense. 
SCHLITTER, F. H. M. (1995). Participação da comunidade na co-gestão das Áreas de Preservação Ambiental (APAs). In: TAUK-TORNISIELO, S. M. et al. (Org.). Análise ambiental: estratégias e ações. 1. ed. Rio Claro, SP. T. A. Queiroz Editor.

SCHWARTZMAN, S. (1988). As bases autoritárias do Estado brasileiro. Rio de Janeiro, RJ. Ed. Campus.

SENRA, J. B. (2001). Água, o desafio do terceiro milênio. In: VIANA, G.; SILVA, M.; DINIZ, N. (orgs). O desafio da sustentabilidade. Um debate socioambiental no Brasil. São Paulo, SP. Ed. Fundação Perseu Abramo.

SILVA, M. G. L. (1994). Conceitos de desenho no planejamento da paisagem. Paisagem e Ambiente: ensaios (FAU-USP), São Paulo, n. 5, p.81-90.

SMYTH, J. C. (1995). Environment and education: a view of changing scene. In Environmental Education Research, v. 1, n. 1, 3-20.

SOUZA, C. (2003). Políticas públicas e orçamento público. Conflitos e cooperação. In: BENEVIDES, M. V. VANNUCHI, P. e KERCHE, F. (orgs.). Reforma política e cidadania. Instituto Cidadania. São Paulo, SP. Ed. Fundação Perseu Abramo.

SOUZA, J. (2001). (org). Democracia hoje. Novos desafios para a teoria democrática contemporânea. Brasília, DF. Ed. UnB.

SUSTAINING WATER. http://www.cnie.org/pop/pai/image10.html. (consultado em novembro de 2002).

TELLES, V. da S. (1999). Direitos sociais: afinal do que se trata? Belo Horizonte, MG. Ed. UFMG.

- (1994). Sociedade civil e a construção de espaços públicos. In: DAGNINO, E. (org.). Os anos 90: política e sociedade no Brasil. São Paulo, SP. Brasiliense. . (1986). Ecodesenvolvimento, crescer sem destuir. São Paulo, SP. Ed. Vértice. 
TRINDADE, H. (2003). Reforma política. Os desafios da democracia social. In: BENEVIDES, M. V.; VANNUCHI, P. e KERCHE, F. (orgs.). Reforma política e cidadania. Instituto Cidadania. São Paulo, SP. Ed. Fundação Perseu Abramo.

TUNDISI, J. G. (1996). Conferência de Abertura. In VIII Seminário Regional de Ecologia. São Carlos. PPG-ERN, UFSCar.

VALÊNCIO, N. F. L. da S. et. al.. (2004). Caracterização da Vulnerabilidade dos Assentamentos Humanos Perante os Perigos Hidrometeorológicos: um estudo de caso no município de São Carlos/SP. In: Anais do II Encontro da ANPPAS - Associação Nacional de Pós-Graduação e Pesquisa em Ambiente e Sociedade, maio de 2004. (artigo digital).

. (2003). Gestão de Desastres no Brasil: considerações sociais acerca das políticas de emergência ante os perigos hidrometeorológicos. In: MARTINS, R. \& VALENCIO , N. F. L. S. (orgs). Uso e Gestão dos Recursos Hídricos no Brasil. Desafios teóricos e político-institucionais. Vol. II. São Carlos, SP. Ed. Rima.

VERGARA, A. G. (et. al.). (2003). Novos espaços democráticos. Diálogo social no Brasil e a experiência da Espanha. São Paulo, SP. Ed. Fundação Perseu Abramo.

VIANA, G.; SILVA, M.; DINIZ, N. (orgs.) (2001). O desafio da sustentabilidade. Um debate socioambiental no Brasil. São Paulo, SP. Ed. Fundação Perseu Abramo.

VIEIRA, L. (2004). Cidadania e globalização. São Paulo, SP. Ed. Record.

VIEIRA, M. C. do. (2000). Luta ambiental e democratização em Maceió: momentos de um processo. Tese apresentada à Faculdade de Ciências e Letras da Universidade Estadual Paulista. Araraquara, SP.

VIEIRA, P. F. (1995). Meio ambiente, desenvolvimento e planejamento. In: VIOLA, E. J. et. al. (1995). Meio ambiente, desenvolvimento e cidadania: desafios para as Ciências Sociais. São Paulo, SP. Cortez Editora.

VIGEVANI, T. (1989). Movimentos sociais na transição brasileira: a dificuldade de elaboração do projeto. In: Revista Lua Nova, pp. 17:93. 
VIOLA, E. \& MAINWARING, S. (1997). Novos movimentos sociais. SCHERERWARREN, I. \& KRISCHKE, P. J. (orgs.). Uma revolução no cotidiano? Os novos movimentos sociais na América do Sul. 2. ${ }^{a}$ edição. São Paulo, SP. Editora Brasiliense.

VIOLA, E. J. et. al. (1995). Meio ambiente, desenvolvimento e cidadania: desafios para as Ciências Sociais. São Paulo, SP. Cortez Editora.

VIOLA, E. J. \& BOEIRA, S. (1990). A Emergência do Ambientalismo ComplexoMultissetorial no Brasil (particularmente na microrregião de Florianópolis) nos anos 80. In: Universidade e Sociedade face à Política Ambiental Brasileira. Brasília, IBAMA.

WAMPLER, B. (2003). Orçamento participativo: uma explicação para as amplas variações nos resultados. In: AVRITZER, L. NAVARRO, Z. (2003). A inovação democrática no Brasil: o orçamento participativo. São Paulo,SP. Cortez Ed.

YOUNG. I. M. (2001). Comunicação e o outro: além da democracia deliberativa. In: SOUZA, J. (2001). (org). Democracia hoje. Novos desafios para a teoria democrática contemporânea. Brasília, DF. Ed. UnB. 